\title{
SF
}

524

- 52

T 4

536 


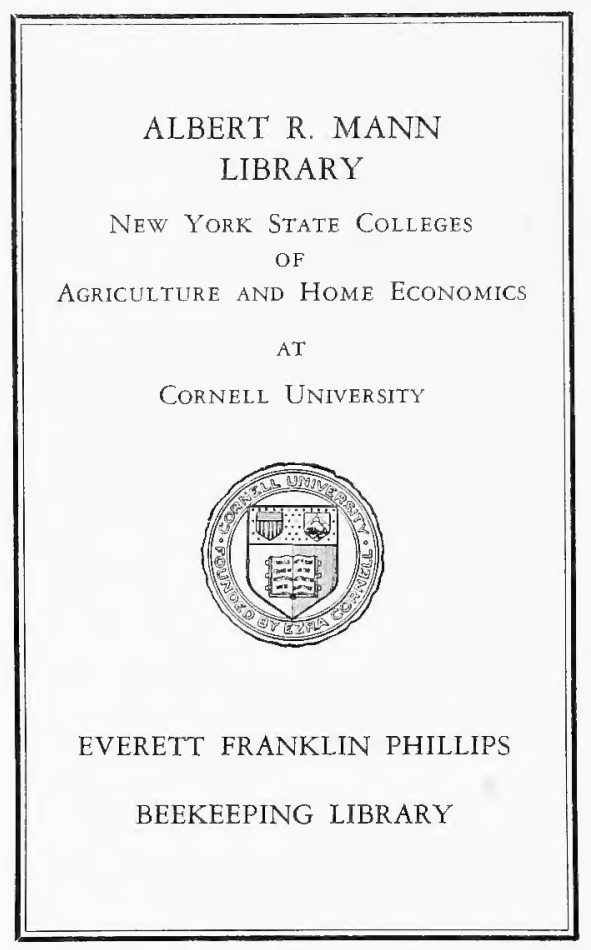




\title{
TEXAS DEPARTMENT OF AGRICULTURE BULLETIN
}

\author{
Published Bimonthly by the Texas Department of Agriculture \\ AÜSTIN, TEXAS
}

\section{Texas Beekeeping}

$\mathbf{B y}$

\section{LOUIS H. SCHOLL}

Consulting Apicultural Expert

Texas Department of Agriculture.

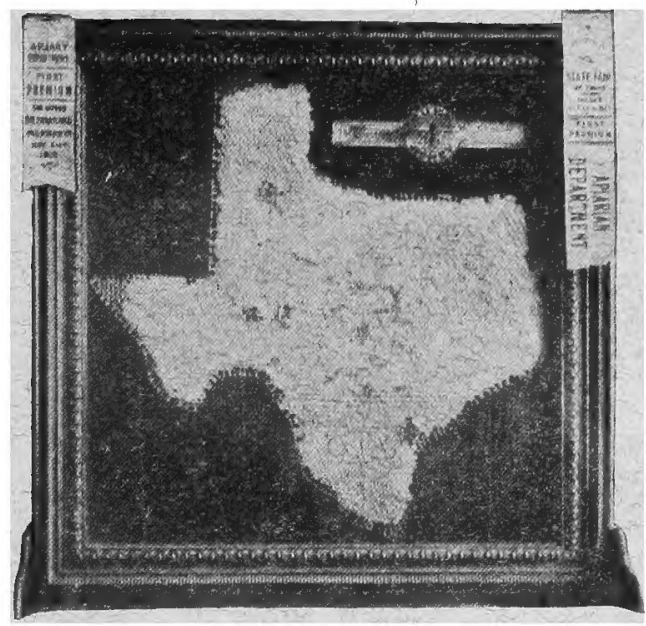

\section{ED. R. KONE}

Commissioner of Agriculturo.

For a copy of this Builetin apply to the Oommlssloner of Agriculture, Austin, 'Taras:

Intered as second-class matter, May 8, 1909 , at the Post Office at Austin, Pexas, unier Act of June 6,1000 .

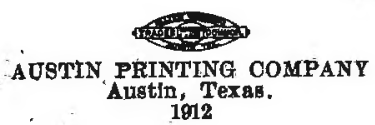




\section{Cornell University Library}

The original of this book is in the Cornell University Library.

There are no known copyright restrictions in the United States on the use of the text.

http://www.archive.org/details/cu31924003421439 
185-112-2010

\section{TEXAS DEPARTMENT OF AGRICULTURE \\ BULLETIN}

Published Bimonthly by the Texas Department of Agriculture

AUSTIN, TEXAS

March-April, 1912

Number 24

\section{Texas Beekeeping}

By

\section{LOUIS H. SCHOLL}

Consulting Apicultural Expert

Texas Department of agriculture.

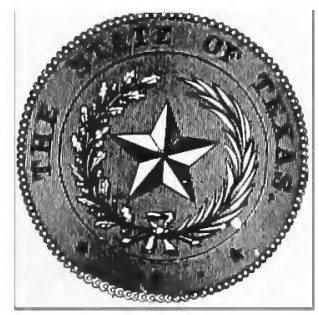

\section{ED. R. KONE}

Commissioner of Agriculture.

For a copy of this Bulletin apply to the Commissioner of Agriculture, Austin, 'Texas.

Fntered as seeond-class matter, May 8, 1909 , at the Post Office at Austin. Texas, unier Act of June 6,1900 .

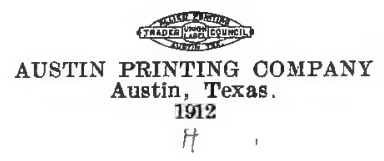




\section{HONEY MAP OF TEXAS,}

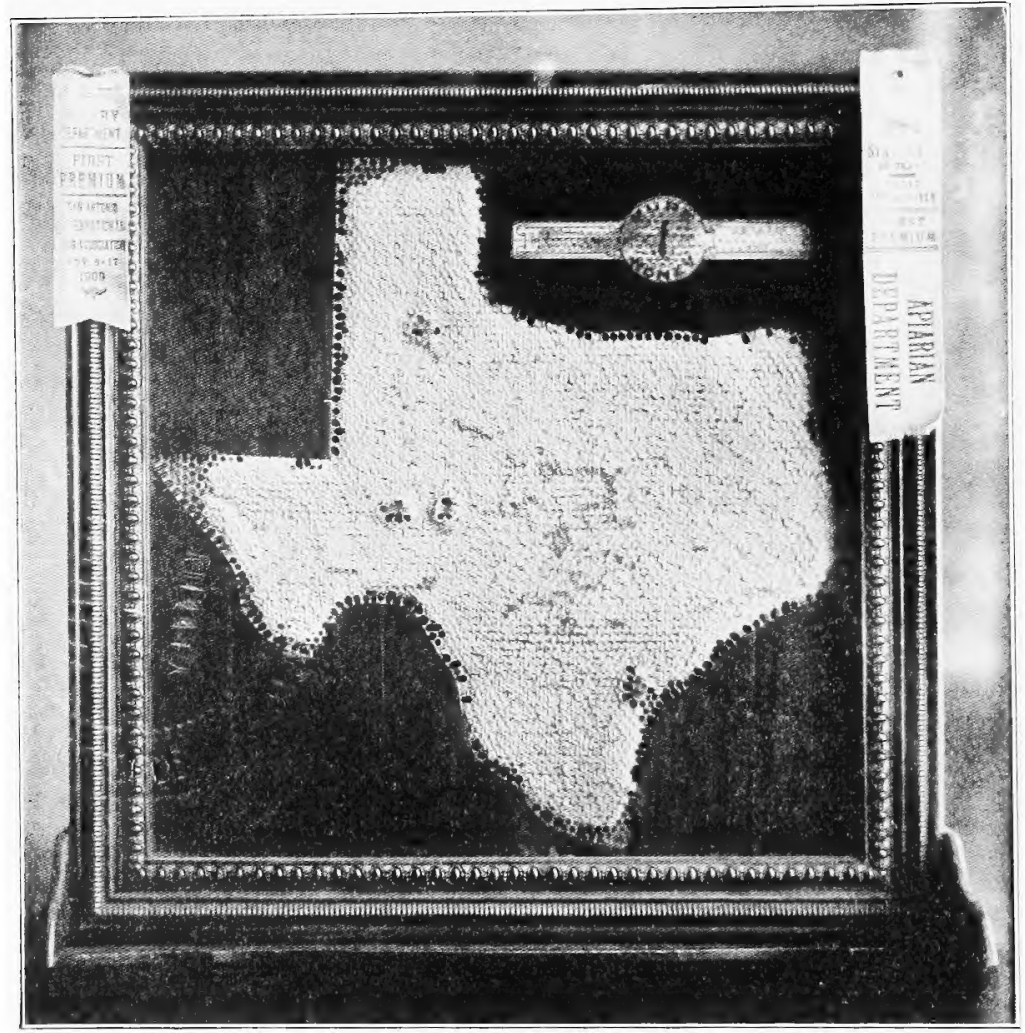

The Leading Honey Producing State in the United States.

(Built by the bees of Wm. Wiede. Maxwell, Texas.) 


\section{PREFACE.}

This bulletin is printed to meet the requirements of those who desire more complete practical instruction in the art of successful beekeeping in Texas than is afforded by any other publication that has issued from the press - men who have grown old in the business, and yet who realize that they can still learn something from a work of the sort, and others who contemplate engaging in apiculture, either exclusively or as a side line to horticulture or general farmingand, also, to promote the spread of beekeeping over the State, for the direct advantages of increased production of honey and beeswax, and for the still greater benefits of larger yields of fruit and many farm crops that will accrue from the pollenizing activities of the bees. The author, Mr. Louis H. Scholl, of New Braunfels, is one of the most widely and thoroughly experienced and eminent beekeepers in the United States, and owner and operator of apiaries that, in number of colonies, magnitude and value of output, and profit-yielding, rank with the best in the country.

An old and good rule is that, where success is desired, it is well to take the advice of the successful. It can be applied in this instance with certainty of excellent results.

Mr. Scholl is Consulting Apicultural Expert of the Texas Department of Agriculture, and, as such, will answer any question, addressed to this Department, that readers may wish further light on, after reading the bulletin.

There is not a farmer in Texas to whose interest it would not be to have an apiary on his place, and comparatively few, who, on account of location, could not have one at small initial expense and maintain it in paying condition without consuming time needed for other farm operations.

To have for the home table an abundance of choice honey-the most delicious and wholesome sweet-is an item that would, alone, compensate for money and labor invested. Added to this, under proper management, there would be sure to be a surplus of honey and considerable beeswax that could be sold at good prices, and, under some circumstances, there could be made every year a barrel or two of superior vinegar that there would be no difficulty in finding purchasers for. Furthermore, an apiary situated in the right place, would result in larger crop yields than if there were invested in fertilizers many times the money and the value of the labor put into it.

I hope that this clear, concise and admirable monograph will be like the little leaven that was placed in the measures of meal and that soon leavened the whole mass, and the result be that, in the near future, Texas will be dotted over with apiaries and there will be solved an important part of the problem of producing larger per acre yields of crops, at less expense than smaller yields are now obtained.

ED. R. KonE,

Commissioner of Agriculture. 



\section{CONTENTS}

Page

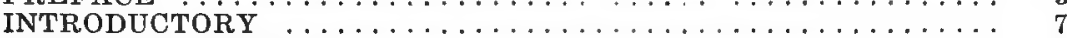

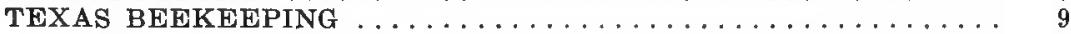

The Old and the New Beekeeping.................. 9

The Farmers' Greatest Friends..................... 10

The Bees' Real Mission....................... 11

Some Striking Examples....................... 12

More Bees, Better Crops......................... 14

Do Bees Puncture Fruit?. . . . . . . . . . . . . . . . . 14

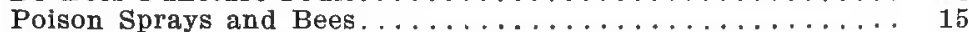

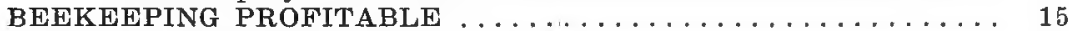

How Many Colonies for a Living................... 17

Who May Keep Bees?. . . . . . . . . . . . . . . . . . . . 17

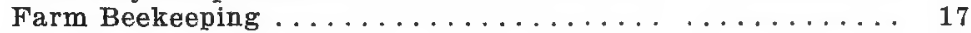

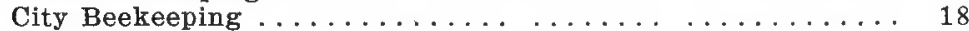

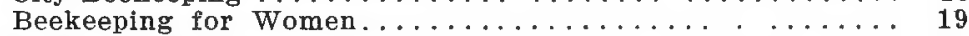

Making a Beginning ........................ 20

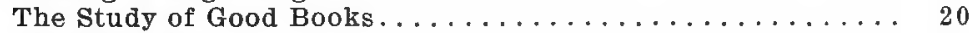

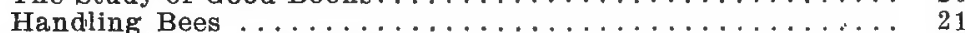

THE FAMILY OF HONEY BEES. . . . . . . . . . . . . . . . . . 23

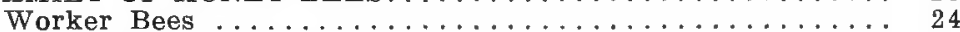

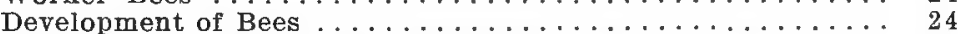

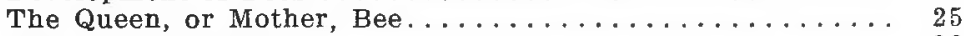

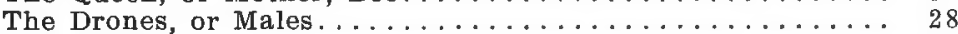

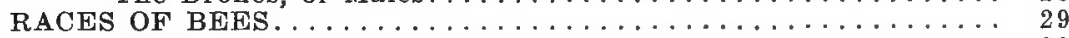

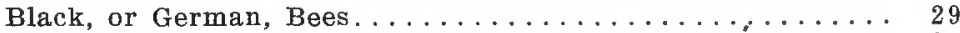

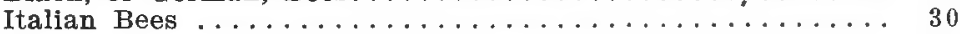

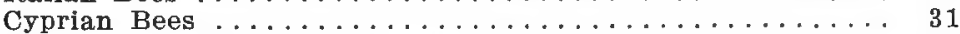

Holy Land, or Palestine, Bees ...................... 31

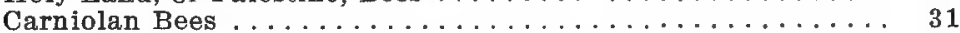

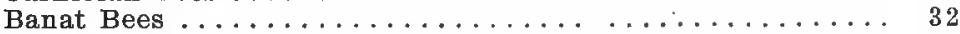

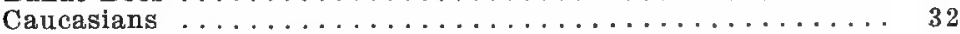

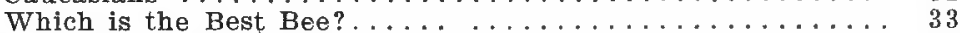

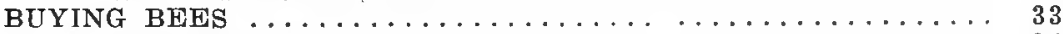

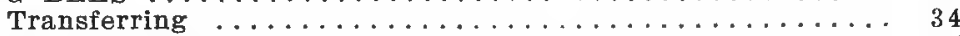

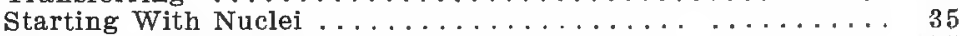

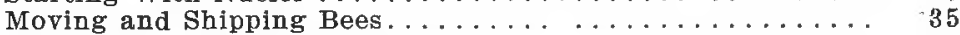

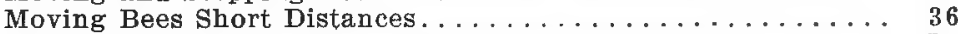

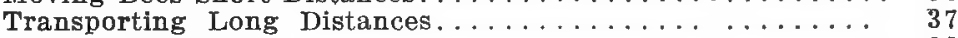

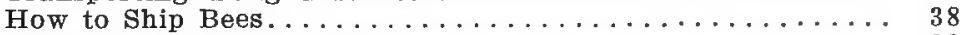

Shipping Bees by Freight. ................... 39

LOCATING BEES IN THE APIARY . . . . . . . . . . . . . . . . 39

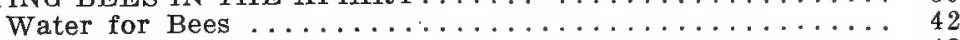

Locating out-Apiaries ...................... 42

How Far Do Bees Fly?......................... 44

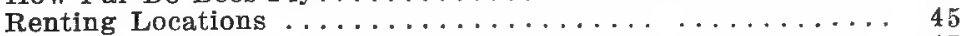

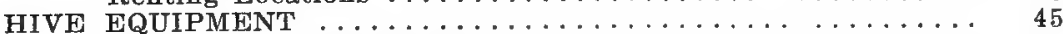

Hive Bottoms and Covers .................... 47

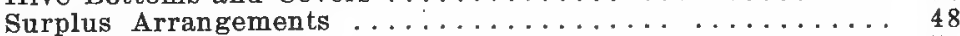

Make or Buy Hives?......................... 50

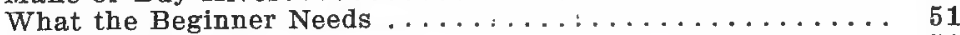

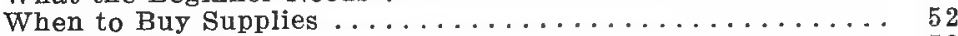

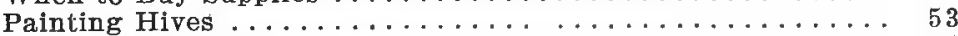

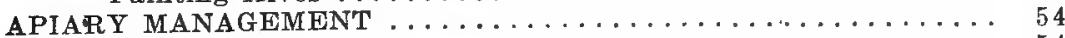

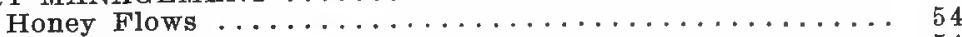

Spring Examinations ...................... 54

Building-Up Colonies ... ................... 55

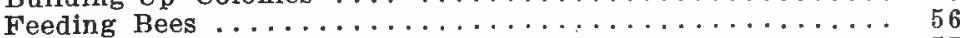

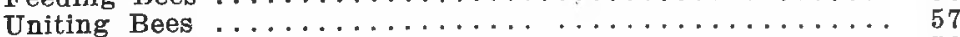

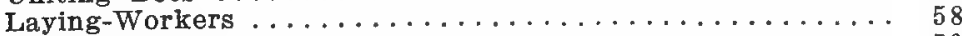

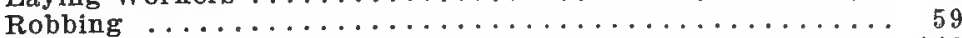

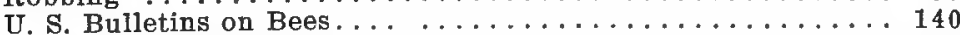

Texas Department of Agriculture Bulletins.............. 143 
HONEY PRODUCTION

What is Honey? $\ldots \ldots \ldots \ldots \ldots 6$

No Manufactured Comb Honey................. 62

Preparing the Supers .................... 62

Putting in the Foundation................... 63

When to Put on Supers..................... 64

Why Bees Don't Work in Supers...............6 65

COMB BUILDING AND BEESWAX ................ 65

Rendering Beeswax $\ldots \ldots \ldots \ldots \ldots \ldots \ldots \ldots 6 \ldots \ldots \ldots$

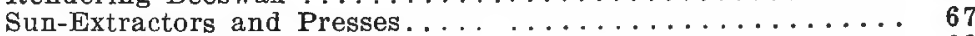

Comb Foundation ........................ 68

Why Comb Honey Costs More................... 70

Artificial Comb ....................... 70

WORK SHOP AND HONEY HOUSE .................. 71

Under One Roof, But Separate................. 71

Everything in Its Place.................... 73

Where to Keep Honey. . . . . . . . . . . . . . . . . 74

Honey as a Food ........................ 74

Honey Vinegar ....................... 75

COMPARATIVE PROFIT IN COMB AND EXTRACTED HONEY . . . . 76

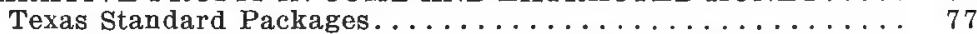

Bulk Comb Honey ...................... 78

Taking Off Honey......................... 80

How It Is Packed. . . . . . . . . . . . . . . . . . . 83

Extracted Honey ..................... 85

MARKETING HONEY ......................... 88

Low Honey Prices..................... 89

A Honey Price List ..................... 90

Shipping, Sight Draft Attached................ 91

Shipping Honey ......................... 92

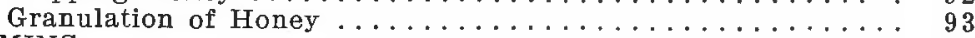

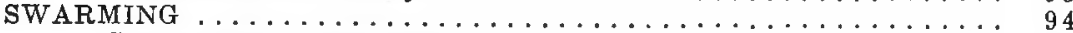

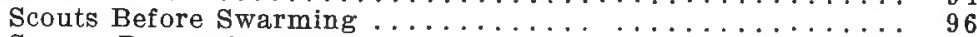

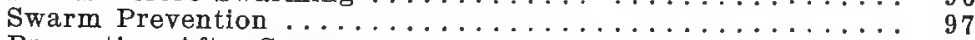

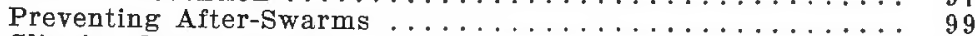

Clipping Queen's Wings ....................

Natural or Artificial Increase .................... 101

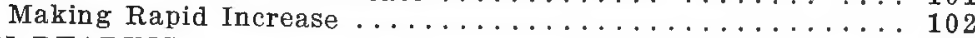

QUEEN REARING ..................... 104

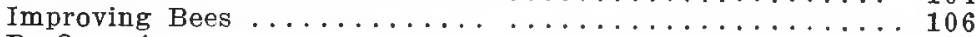

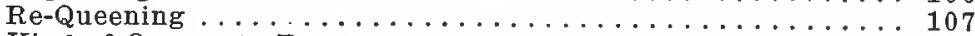

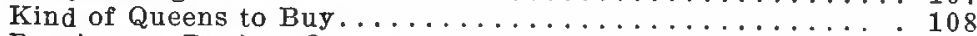

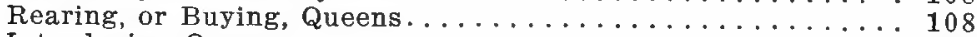

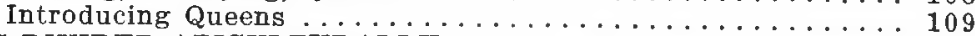

TEXAS DIVIDED APICULTURALLY $\ldots \ldots \ldots \ldots \ldots \ldots \ldots \ldots \ldots \ldots \ldots \ldots \ldots \ldots$

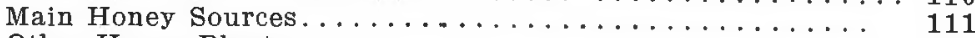

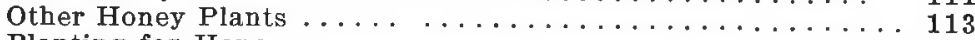

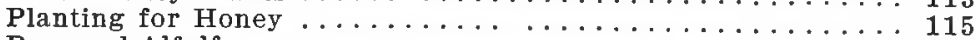

Bees and Alfalfa . . . . . . . . . . . . . . . . . . 115

Buckwheat as a Honey Plant. . . . . . . . . . . . . . . 115

White and Yellow Sweet Clover ....................

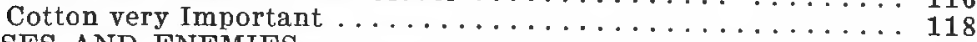

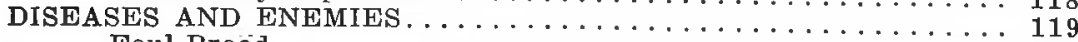

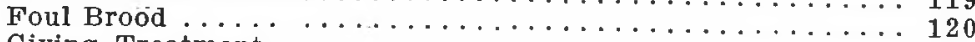

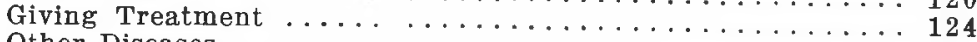

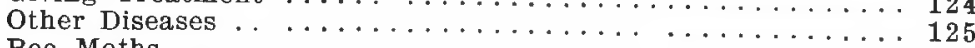

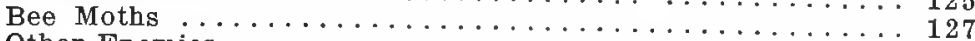

Other Enemies $\ldots \ldots \ldots \ldots \ldots \ldots \ldots \ldots \ldots \ldots \ldots \ldots \ldots \ldots \ldots \ldots \ldots \ldots \ldots \ldots \ldots \ldots \ldots \ldots \ldots \ldots$
WINTERING

134

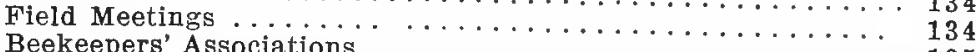

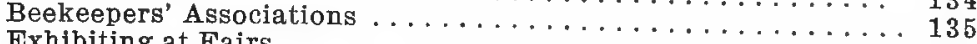

Exhibiting at Fairs . . . . . . . . . . . . . . . 136

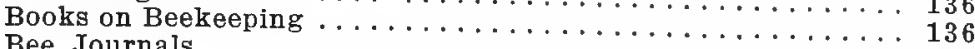

Bee Journals $\ldots \ldots \ldots \ldots \ldots \ldots \ldots \ldots \ldots \ldots \ldots \ldots \ldots \ldots \ldots$

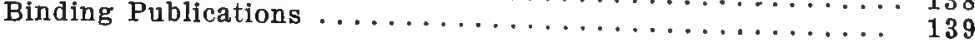




\section{INTRODUCTORY.}

As in many other things, Texas, the great Lone Star State, ranks first in the beekeeping industry. So large in size that the area of fourteen Northeastern States, if superimposed upon it, would not cover its surface without leaving a good portion exposed to view and

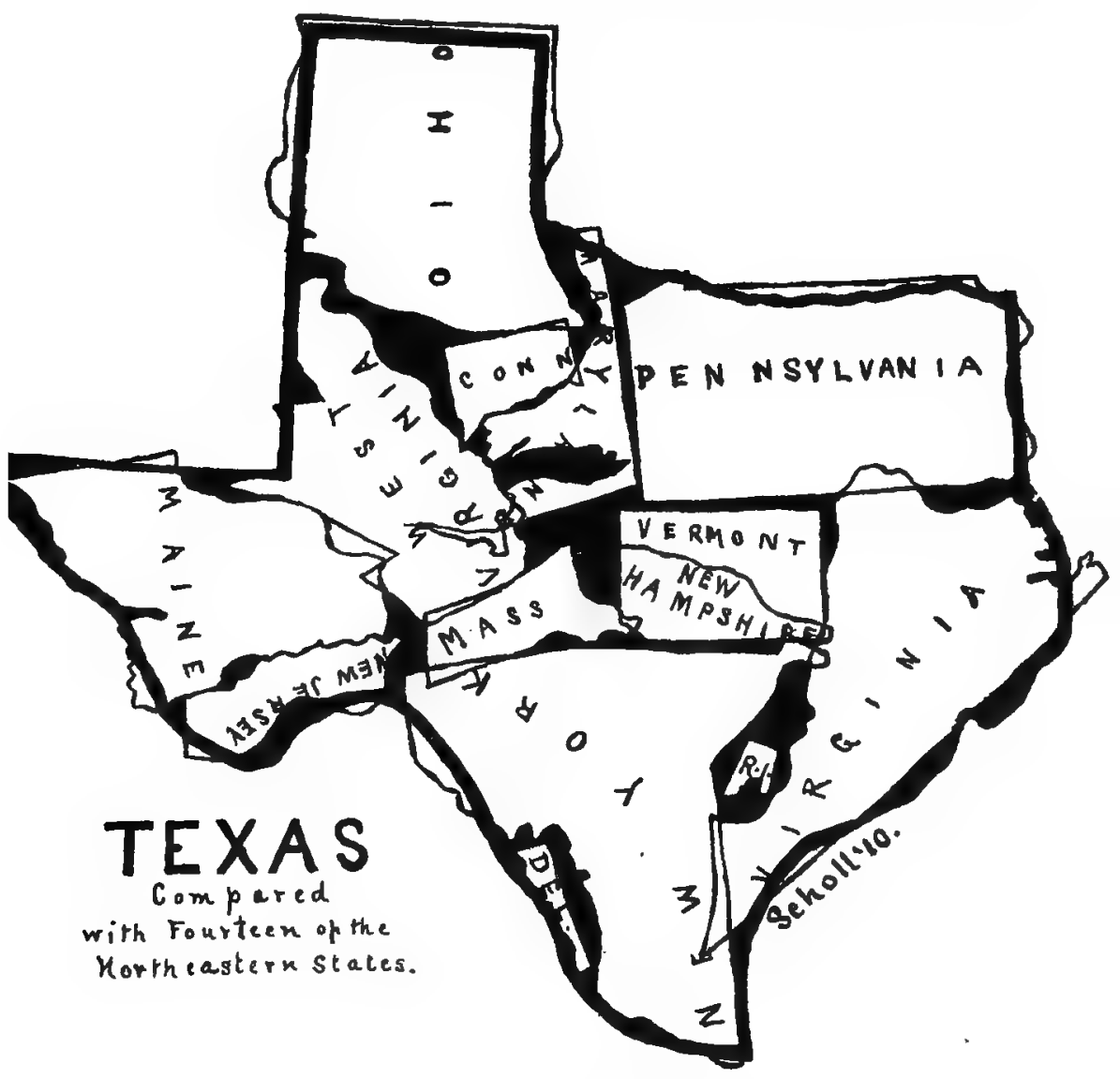

extending over a distance of more than seven hundred miles from North to South and another hundred miles more than this in breadth, it can well pride itself on advantages no other State in the Union possesses.

In this wide extended and magnificent area the beekeeping industry has been characterized by great expansion and marked improvement in the last quarter of a century and, as a consequence, the demand for reliable information pertaining to the pursuit has increased to a remarkable extent. This information is desired not 
only by our own people of Texas, but by outsiders more especially, whose attention has been attracted to the exceptional possibilities in Texas beekeeping. It may be well to state that no other part of the country is receiving as much attention in the apicultural world at this time as Texas is, and that, although Texas is now the leading honey producing State, it is destined to become still more important apiculturally. With a great number of its localities unoccupied by bees and much of its beekeeping yet unimproved, the opportunities for the progressive apiculturist are excellent indeed.

The growing desire for reliable information on the subject is gratifying, since it shows an artiv" interest in beekeeping, to the advantage of the State, which is already in the first rank in so many things and of which we as Texans are so justly proud. Letters of inquiry have become so numerous that it is impossible to reply to them promptly and intelligently hy correspondence and, for that reason, this bulletin has been prepared and, it is hoped, will prove acceptable.

It is impracticable to cover all subjects in a bulletin of this kind, however. The vast extent of the State, its great differences in altitude, latitude and climatic romditions, together with the consequent variety of its flora and the variance of the numerous blooming periods of these, call for modifications of methods and application to suit the several localities.

While the apiarist must deal with conditions resembling almost identically those of the tropics in the most southern portion of the State, North Texas presents others that are very much different. This is not only true as regards temperature, but the whole range of atmospheric phenomena and resulting effects on the floral vegetation upon which the honer bees find their subsistence.

Such other information as is not contained in this bulletin will be cheerfully supplied, and may be obtained by dirceting inquiries to the Consulting Apicultural Expert of the Texas Department of Agriculture, Austin, Texas.

The tendency is for old apiarists to keep more bees and for others to engage in the business. I hope this spirit will continue and difH. fuse itself till all who can profitably embark in the pleasant and profitable pursuit will do so, for it would mean gratifying pushing forward of the car of progress in the State. I trust that all who respond to the impulse will do so with the determination to keep bees better than ever has been done before. The opportunities in Texas for energetic, interested persons are excellent. It must be remembered that adverse seasons may be met with here, as elsewhere: but they are comparatively few and far between, and that, compared with other parts of the country, they are above the average of favorableness. Taking everything into consideration, the future of Texas apiculture is one of creat, and, in my opinion, assured promise.

Louis H. ScHOLI. 


\section{TEXAS BEEKEEPING.}

Many who see the busy honey bee, with its merry hum, flying from flower to flower, in its daily toil, little realize what an intensely interesting and fascinating study is connected with so small a bit of insect life. Closer investigation will reveal that while a single bee, with all its energy and industry and the innumerable journeys that are made by it during its short life of toil, will collect only about a teaspoonful of honey during a season, yet more than a hundred pounds have been taken from a single hive, or colony, of bees. Time and again single colonies have stored from two hundred to three hundred pounds, or more, of honey during a year. Although this does not prevail with every colony of bees, it shows to what extent nature makes use of little things to accomplish large results. It is thus that these small creatures, the honey bees, are responsible for no less an accomplishment than that of placing Texas in the lead of all other States as the foremost producer of crops of honey, beeswax and other products of the apiary.

From a small beginning the beekeeping industry in this State developed rapidly until, several years ago, Texas attained first place in honey production. The annual output of honey gathered and stored by honey bees in Texas is cnormous. It is impossible to give figures covering present production, since reliable statistics are not at hand at this writing.

TEE OLD AND NEW BEEKEEPING.

Although honey bees are not native to America, it was not very long after they were brought to Florida by the Spaniards in 1763 that they drifted westward and finally into Texas, where they found easy :ubsistence upon the great abundance and variety of natural flora.

While the early settlers depended upon obtaining their supply of honey from bees in hollow trees and caves in which they dwelt, it was not long until honey bees were kept in sawed-off "logs" brought from the forests and set on end under orchard trees, or in a convenient place in a fence corner. These "logs" were later replaced by plain upright box hives, or "box gums," as they were called, and which are still to be seen in many places. These rudely constructed and un-

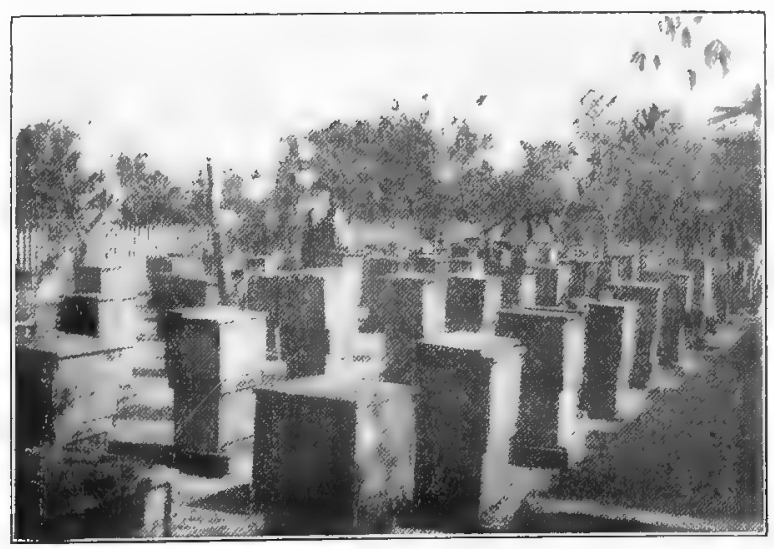

Old Style Bee Gums. profitable hives and the attendant crude methods of beckeeping are waning rapidly, how ever, and modern movable frame hives are everywhere taking their place.

The antiquated way of "robbing" "bee gum s" should become a thing of the past. The cruelty connect- 
ed with the old method of ruthlessly cutting the combs of honey from the box hives after these have been carelessly pried open, is nothing short of barbarous. The bruising and mashing of beautiful combs is a disagreeable process in itself, and the drowning of, and otherwise destroying, thousands of little innocent bee lives by the rude hands of a merciless owner is to be detested.

How different the beekeeping of today, with the movable frame hive by which every part of the interior of a colony of bees can be examined at will, without the destruction of the most tender comb or the life of a single bee! And it is hoped that the instructions in this bulletin will help to bring about a more complete change, that the old-time, unprofitable "bee gum" may go, and the modern frame hive take its place everywhere.

\section{THE FARMERS' GREATEST FRIENDS.}

Most of the bees in the State are kept on the thousands of Texas farms, each farm containing generally only a few hives, or colonies, of

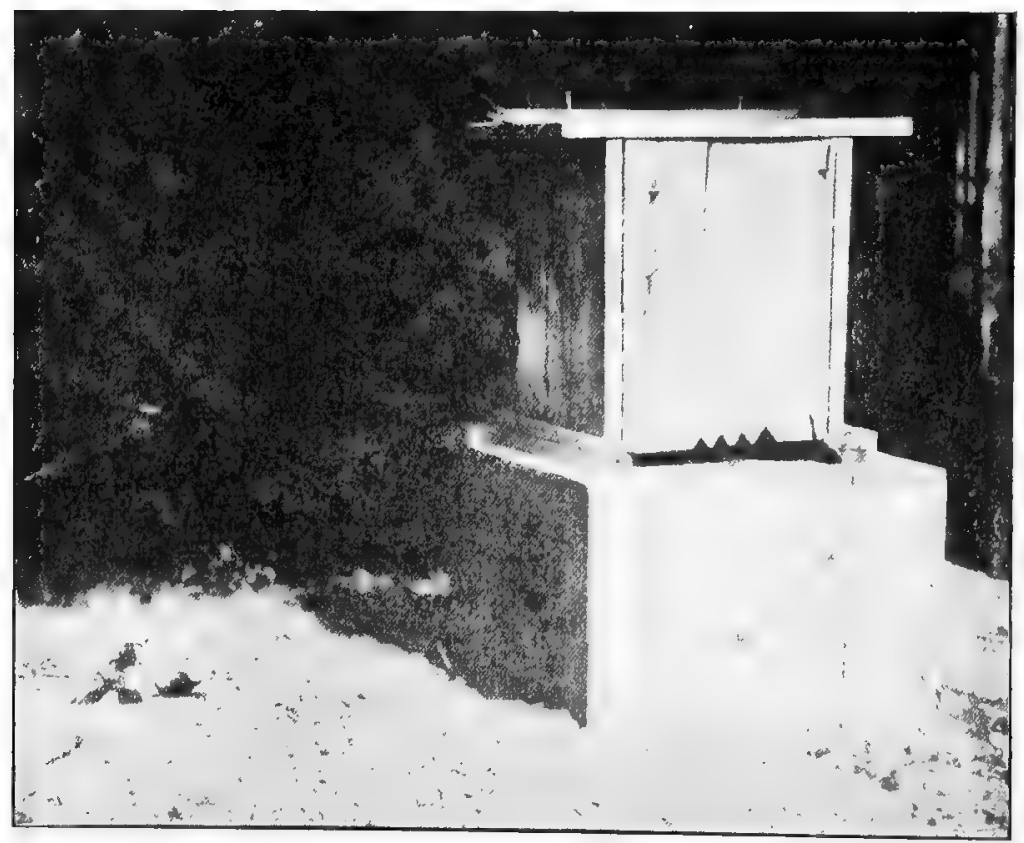

The unprofitable "bee gum" from which only a very small crop of honey is obtained.

bees, or just enough to supply home demand for honey for the farmers ${ }^{r}$ table if the bees are given the proper care and attention. To find bees on so many farms is a gratifying circumstance, as there are very few places where several colonies of bees can not be kept profitably, and it is to be hoped that more of the great number of farms where none are kept now will be stocked with a proper supply. No farm is 
complete without a few colonies of bees that will furnish that most delicious natural sweet, pure honey, that can not be replaced as a most palatable, healthful, nourishing food.

A serious trouble and a great mistake of the majority of farmers, however, is their neglect of these most important of their friends, the honey bees. Nothing suffers more easily from this than these little creatures. They should receive as good care as is given to anything else on the farm. Their value on the farm can not be overestimated.

\section{THE BEES' REAL MISSION.}

It is not generally sufficiently understood that honey bees were not only created for the purpose of furnishing mankind with delicious honey, but for another and much more important reason-that of fructifying the flowers visited by them so it may be made possible for these to bear fruit and seeds. The most of our host of plants absolutely require the visits of the honey bees, or other insects, to carry pollen from one flower to another and thereby fertilize the blossoms. Pollen is gathered by bees from flowers and carried to the hives in little bright colored pellets on their hind legs, for food. They must have pollen to prepare the partly digested food with which the "ing larvae are fed. Inability to secure sufficient pollen causes delayed, or diminished, progress of the colonies of bees. Ordinarily but one kind of flower is visited on a trip when pollen is being gathered. In gathering either pollen or honey the bees come in contact with the pollen grains of the blossoms, which adhere to their hairy bodies and are then carried to other flowers visited by them. In passing from flower to flower some of the pollen grains come in touch with the stigmas of each flower visited, which effects cross fertilization and thorough setting of fruits and seeds. It is thus that the bees pay abundantly, by their services, for the treasures the nectar yielding blossoms offer to them. The exceeding interdependence of flowers and insects and the vast necessity of this has long been recognized by horticulturists and other authorities.

Honey bees are the most important distributors of pollen of all in-

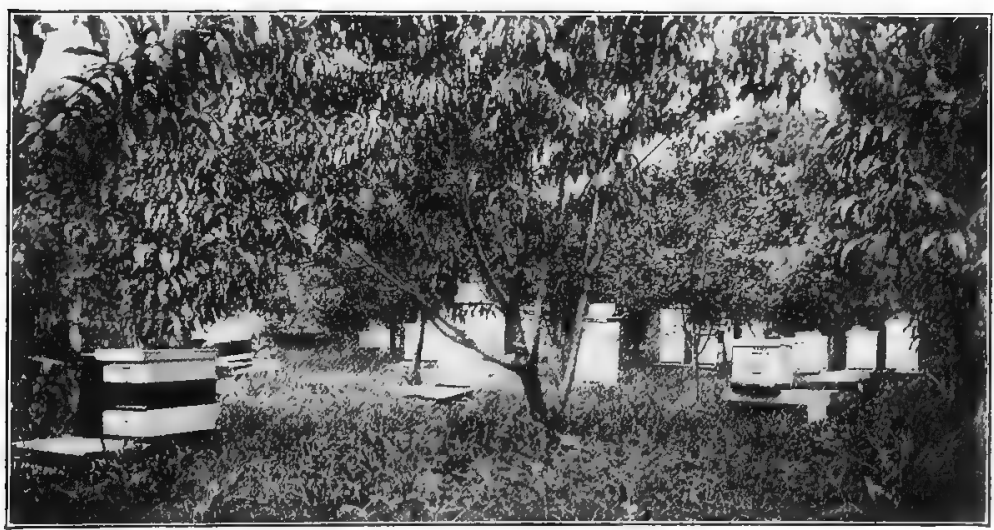

Where the orchard pays. 
sects because they appear in larger numbers, especially early in the season, and their greater activity makes them more useful in the great work they help to perform. It is estimated that the value of honey bees as pollen distributors is far greater to our country than the value of the crops of honey produced. We owe it to honey bees that we have larger quantity and better quality of fine fruit, vegetable and cereal crops than we would otherwise have. Of this there is not the least doubt. Since honey bees are general pollen gatherers, appear in greater numbers, visit a far larger number of blossoms over a greater territory, and do this more thoroughly than any other insect, it is apparent that they are indeed mo:t valuable friends to mankind, a fact that should receire more than passing notice.

In plants or flowers we have sex very similar to that in animals, and it is just as necessary that fertilization take place in these before fruit can be borne or seeds be developed. While both male and female sexes exist in the same flower of many plants, there are some plants in which the male sex exists in one and the female in another flower of the same plant, and in still others each sex is confined r.lltirely to one plant. In any case the arrangement is so that it is neces-

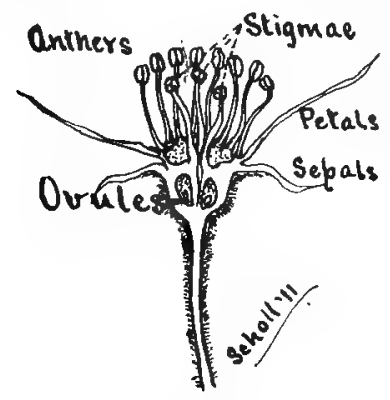

Ap p \&

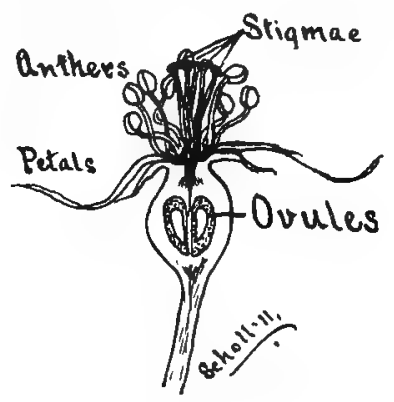

$2 \in x$

sary that the pollen grains from the anthers of the male part of one blossom reach the stigma of the female part of another where they enter into the ovules within the blossom and complete fertilization, after which the development into fruit or seed follows. Without the pollenation of the blossom, fertilization can not take place and the blossom must wither and die instead of bearing frut. If this phenomenon is kept in mind it is possible to grasp quickly why the agency of the honey bees as pollenators is of immense importance and we can better understand the examples that prove abolutely facts that have been long established, but which are, as yet, woll understood by comparatively few.

SOME STRIKIN⿴囗 EXIMPLES.

Where many varieties of trees are mixed in an orchard there is less trouble from the lack of proper pollenation if the weather is warm and dry and the wind can carry the minute pollen grains from flower to flower; but, aren under these conditions, visits of bees make the 
work more thorough. Such ideal conditions do not always exist. This is especially true where the period of bloom is a long one. It is during conditions not so perfect, when the weather is damp and the pollen is sticky and not so easily blown about, that the journeying back and forth of the insects plays a conspicuous part in the production of harvests of fruit or seeds. It is also apparent that when certain varieties are isolated from others of their kind or when the distance between them is great, or they are in a direction from each other that the wind can not carry the pollen, the chances of pollenation are cut off, with the result that there is no setting of fruit. There have been instances where insects were not present, that the side of a tree from which the wind was blowing the pollen bore no fruit, while the other side yielded abundantly, showing how the bees might have aided. Careful investigation has demonstrated beyond a
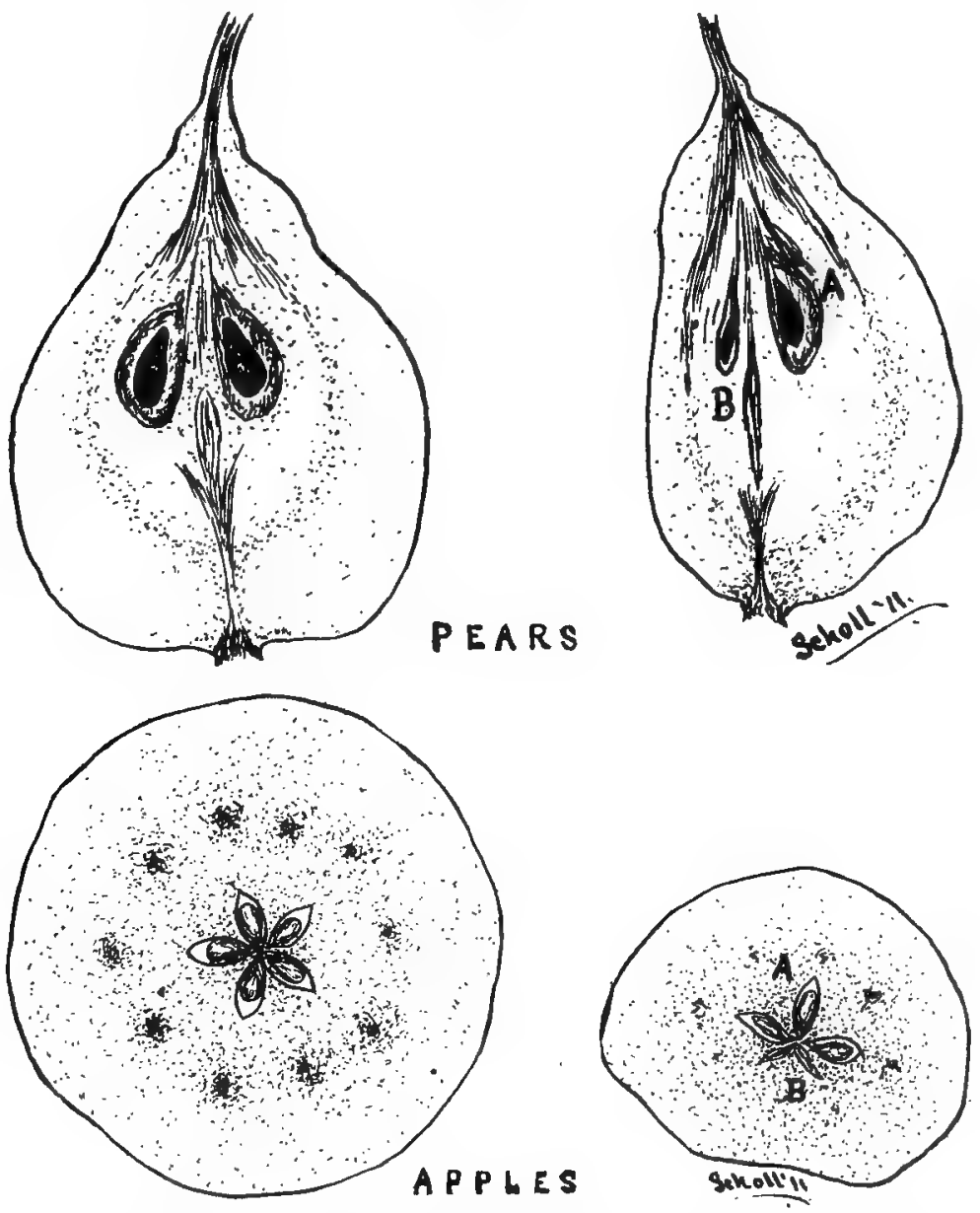

Showing the perfect and imperfect development of the carpels of fruits due to proper and improper pollenation of the blossoms. 
doubt where the agency of the honey bee was not only essential, but absolutely necessary, to insure satisfactory crops.

Even Darwin, the greatest naturalist, recognized, in his time, the value of the honey bees as an important agent in relation to plants when he wisely said: "No bees, no seed. No seed, no increase of the flower. The more visits from the bees the more seeds from the flower. The more seeds from the flower the more flowers from the seeds." This he proved by extensive experiments, and others have done this many times after him. He found in one of his experiments the following results: "Twenty heads of white clover visited by bees produced 2,990 seeds, while twenty heads so protected that bees could not visit them, produced not one seed." The same kind of experiments have been made with strawberries and various other kinds of fruits. Fruit trees that were covered half way with netting, so that the bees could not visit the flowers, bore fruit abundantly on the unprotected parts but none at all, or very little, and that of a very inferior quality, on the other.

MORE BEES, BETTER CROPS.

This shows the importance of keeping a few colonies of bees on every farm, aside from the honey they may yield for their keeping, and it is hoped that this will be appreciated to the extent that not only more bees will be kept, but that they will be kept better.

For the large commercial orchardists, or extensive growers of cucumbers, melons, and various other crops, this question is of more importance still. Where large orchards or fields are planted in solid blocks, or where there are a number close together, cross pollenation is not satisfactory, on account of the lack of sufficient insects to do the work properly, especially when the main part of the trees, or plants, are in bloom. Therefore, the keeping of honey bees near them is to be encouraged, to increase the quantity as well as the quality of the crops. In one instance the owner of a large orchard did not get any fruit from it for eight years and he was about to dig up the entire orchard. Being advised to try keeping honey bees to fertilize the blossoms, he did so. The result was that he sold thousands of dollars worth of fruit thereafter. The idea of keeping bees in this case was mainly to fertilize the fruit blossoms. But the usual crop of honey yielded by them, aside from the beneficial service rendered, increases their value. Many other instances might be given.

\section{DO BEES PUNCTURE FRUIT?}

It is sometimes stated that honey bees destroy fruit, but this is an erroneous conclusion. Since their mouth parts are not constructed for biting, they are unable to pierce the sound skin of any kind of fruit. They do not appear until birds, wasps, or some other agency breaks the skin and causes the juices to exude; then they only come to gather up the wasting juices from the bruised fruit. They do no harm whatever to fruits. Many experiments in which sound fruits, apples, pears, peaches, bunches of grapes, etc., were placed for days 
in hives of bees from which all other food was kept, prove absolutely and conclusively that honey bees can not puncture the skin of sound fruit even if they are starving for want of food.

\section{POISON SPRAYS AND BEES.}

Since the spraying of fruit trees and other plants is coming more and more into practice, it is well to mention here briefly some points of value to both fruit growers and others, as well as to beekeepers. It goes without saying that a poison spray on the open blossoms frequented by honey bees may have a fatal effect on these friends of ours. Careful experiments have shown that all spraying should be done before the blossoms open or after they have ceased to bloom. It has been found that it is not necessary to spray during the period when the blossoms are in full bloom, and this should be remembered by all who may have occasion to spray. Do not kill off your best friends-the honey bees. In many States laws exist that prohibit spraying during the blooming period, for the purpose of protecting bees and other beneficial insects. Good judgment should induce everyone to use necessary precautions and prevent the killing of these most valuable aids, even though restricting laws do not exist.

\section{BEEKEEPING PROFTTABLE.}

When conducted along legitimate business lines and with proper knowledge of requirements, beekeeping is a profitable business for the amount of capital invested. The foundation of success is a good location, as a great deal depends upon locality. The situation must be well suited for beekeeping, with sufficient honey yielding flora of the right kind to insure paying crops. A good stock of bees is also a: prime essential. With these and the exercise of knowledge of what to. do and when to do it, no industry can be placed on a more stable basis than the bee business.

A few colonies may be kept in almost any location with comparatively little time and attention and the work may be done during spare moments. As a vocation apiculture demands the entire time of the beekeeper, and it should be borne in mind that success in the bee business can not be obtained without thought, energy and hard work.

It is difficult to state just what profits may be obtained, since honey yields per colony depend very largely upon locality, the man, the condition of the bees and the number of colonies of bees already in the district. While only enough forage for a few colonies may exist in some places, a much larger number may be supported in others. The beginner should not be mislead and base his figures for the future on the large yields of honey he is securing from a few colonies, as the average yield diminishes with the increase of the number of colonies kept in a place. While it is not unusual to obtain one hundred pounds, or more, per colony in many locations during favorable years, the average in dry seasons may be very much less, or an entire failure may result and necessitate feeding the bees to save them 

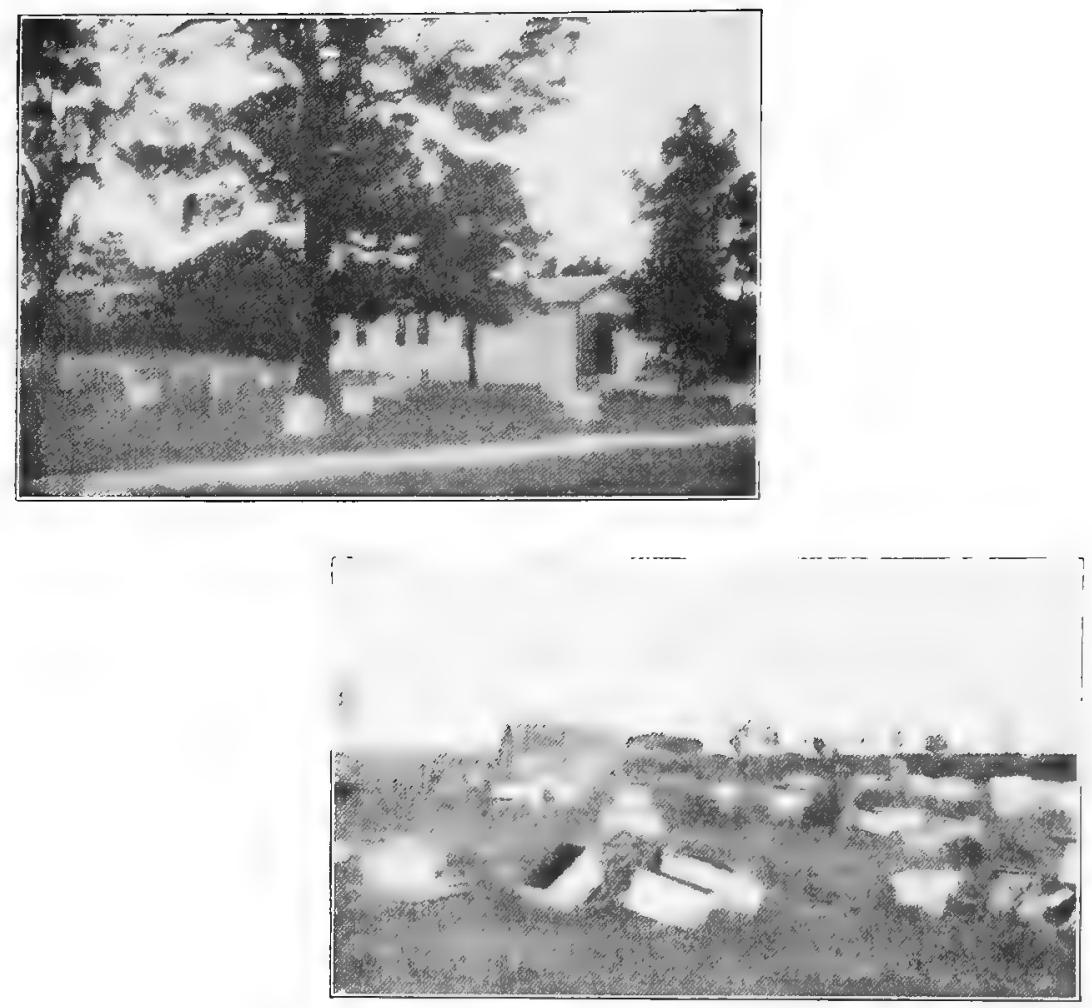

The difference between care and neglect.

from starvation. Although this is rather rare in most localities, it is better to wlard against such possible failures than to be "arried away by alluring calculations that make beekeeping appear as a somer by which one may become quickly rich.

Sixty-five pounds of surphus, of both comb and extracted honey per colony, is a fair yield for the arerage beekeeper, and an average of abuit nine cents a pound for both together is a remunerative price for which it may be sold. From the $\$ 6$ worth of honey and wax ohtained from each colony ought to be deducted approximately 25 per cent to corre the expense of production, interest on capital invested and kerreciation from wear of the supplies and appliance; in use. While the net profit of $\$ 4.31$ per colony may tempt beginners to plunge into beskeeping without due preparation, they are cantioned not to d" so, since one must benin slowly, grow into the business and expand as experience may warrant, or failures are the sure results.

With only a few colonies, the matter of labor is not very important. and to allow 2.5 per cent for it would be rather high. In surh instances there wonld be a grealtel relative profit; but, if large numbers of colonies are kept, the labor must be taken carefully into account. since it becom ar quite an item. It becomes necessary to employ additional 
labor when large apiaries are to be managed, since the work and running expenses increase as the number of these becomes larger.

\section{HOW MANY COLONIES FOR A LIVING?}

This question has been asked many times, and is a hard one to answer. While some persons are possessed of superior executive ability and can manage 1,000 colonies, or more, of bees profitably, the majority do not succeed with more than a few hundred. Assuming that the questioner has carefully begun with only a few colonies and has grown into the business so he understands it thoroughly, he ought to have no difficulty in managing 500 eolonies in several apiaries. Of course, it will be necessary to employ extra help during the main part of the season; but, by doing so, more can be accomplished than by the beekeeper working single-handed.

The average yield per colony would perhaps hardly be as high; but, during a normally favorable year, the figures used above (\$6 worth of homey and wax per colony) should not be too high. In less favorable seasons the output would be less, as a matter of course.

Allowing $\$ 5$ per colony, the total yield of 500 colonies would be $\$ 2,500$. Less the 25 per cent for operation and other expenses, the net income from them would be about $\$ 1,875$. While these figures are only estimated, they will serve, at least, as a guide in determining, approximately, the possible income from any number of colonies. Due allowance should be made for the favorableness, or the unfavorableness, of the year, however, and proper consideration given to the location and the forage where the bees are situated, and last, but not least, the kind of care and attention the bees receive on the part of their owner. All these are factors that determine whether the bee business is profitable or not.

\section{WHO MAY KEEP BEES?}

Bees may be kept in many places and by many persons and in the city as well as in the country. They may be kept either in a small way, or on a more extensive scale, for both pleasure and profit. Any person who possesses the interest, energy, ability and will-power to apply himself earnestly and intelligently to the pursuit may adopt beekeeping and be rewarded not only by the direct profits made, but in the pleasure, the enthusiasm and the fascination that attaches to it and the better health from outdoor exercise it affords.

\section{FARM BEEKEEPING.}

It is but natural that beekeeping prevails to the greatest extent on farms; at the same time there are a great many farms that have no colonies of bees, for the reason, perhaps, that the value of keeping them has been overlooked, or, it may be, fear of handling them or, even, having them on the place. The fact is, that it is not nearly so difficult a task to keep at least a few colonies of them on every farm 
as some people imagine and their intrinsic value ought to cause it to be done. There is nothing nicer than being able to supply the table with delicious, ripe honey right from one's own hives. To provide the family with this healthful and nutritious food is a duty which every farmer, as the head of his household, should feel himself oblicuated to perform. The honey produced should not, by any means; he the only item of value considered, although it is a good source of revenue: the great value of bees as fertilizing agents is of still more importance and in many instances should be the deciding reason for keeping them on the farm.

CITY BEEKEEPING.

Even the resident in town or city is not barred from enjoying the pleasures derived from keeping a few colonies of bees. More than

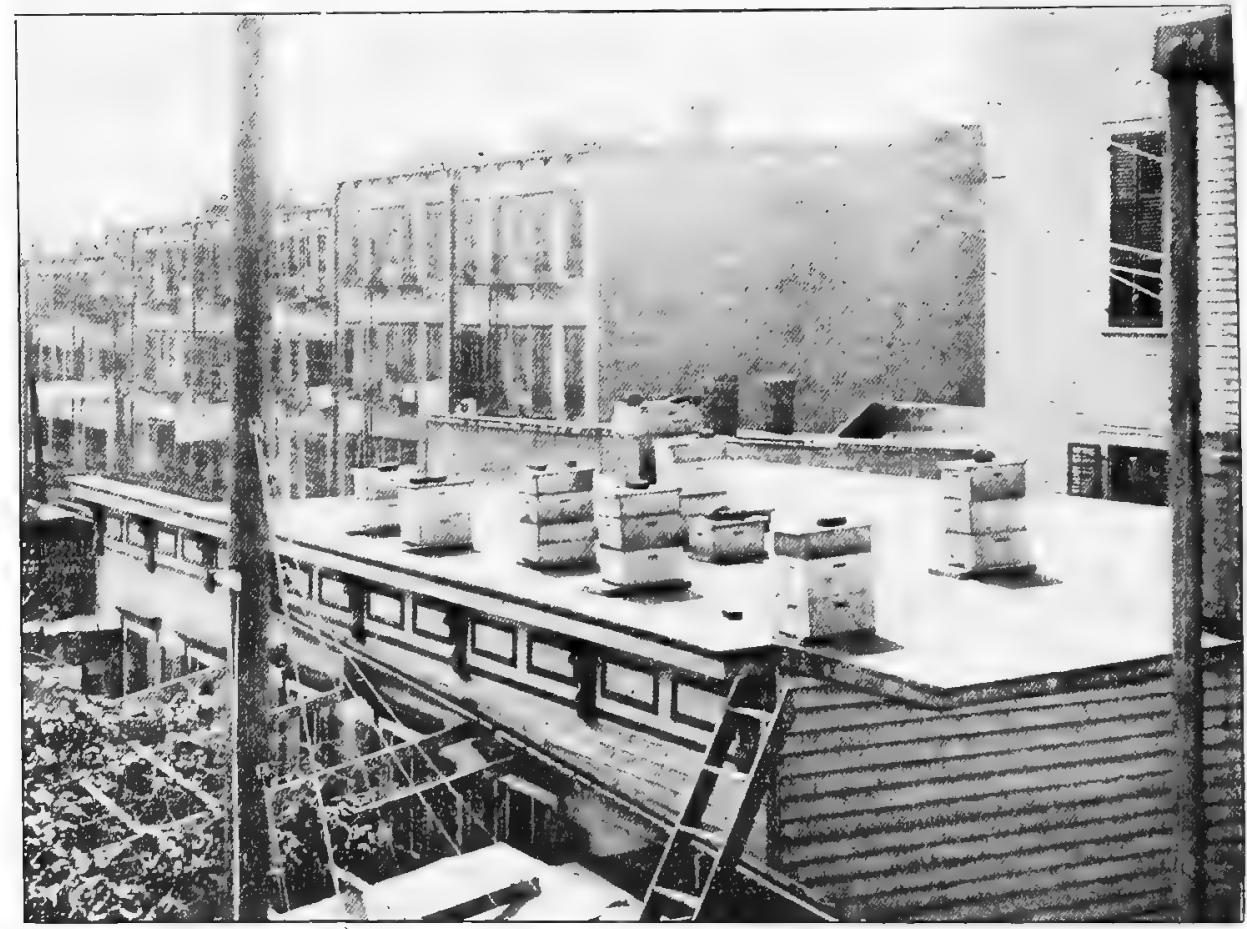

A city rool apiary.

that, many extensive beekeepers, the writer among them, enjoy both the conveniences of city life, while the bees, kept in the city, or scattered far and wide over the country, afford all the pleasures connected with the pursuit. If there is no suitable place in the back yirrl where they may be kept, there may be an empty lot or an outof-the-way corner on some neighbor's place nearby, which might be rented or obtained for the purpose by some satisfactory arrangement. 
A colony or two may be kept in an upstairs room or the attic, or a small apiary be maintained on the roof of a building. There are many such roof apiaries in even our largest cities. As a last resort, it may be feasible to locate the bees somewhere in the outskirts of the eity, especially where the street cars can be used to go to and from the apiary. Out-aparies by the dozen are kept by the writer, ranging in distance from the city from two to nearly two hundred miles away. But no matter where the bees may be located, they provide a great deal of recreation for the person in the city whether he wishes them for a "hobby," a "side issue," or to make beekeeping a sole business.

\section{BEEKEEPING FOR WOMEN.}

The avocation offers fine opportunities for women beekeepers, of which there are a great number. Most of the work is light and easy and especially well adapted for their hands, while the heavier work can be done by stronger hired help. The pursuit provides a great

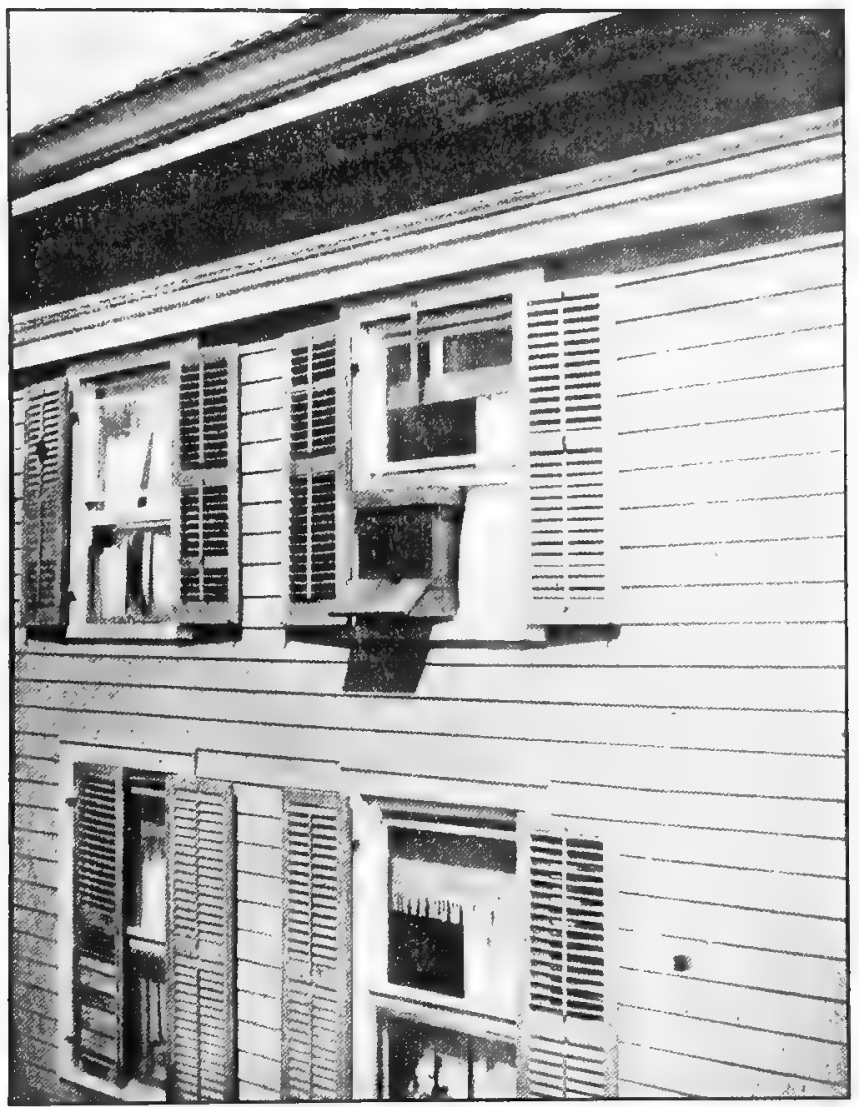

Located in an upper window. 
deal of pleasure and profit, and the outdoor exer'ise in the pure air and sunshine promote; better health. Thus, many women who suffered ill health or were feeble and weak, have been restored to health and made robust by following beekeeping. For hisy housewives, and others, too, who need occasional rest and recreation, there is nothing better than these "pets" to occasionally take their minds alwy from. their daily cares and worry.

As a specialty, beekeeping is very profitable for either man or woman, if proper attention is given to it. It would be folly to tay to pursue it as a business in a poor locality, or to attempt to get sellisfactory results if managed in anything short of a business-like mailner. Effort to do so is what has "alusul many failures in beekeeping.

M.IKING A BEGINNING.

There are many ways in which, a person may stalt beekeeping anil this is one reason why so many questions are asked regarding how a heginner may best start out in this new field. Other's make a beginning without any questions and work themselves in, as it were. while still others plunge heavily into the new undertakin or on a large scale, only to discover later that they are not capable of handling it properly and, as a result, find themselves, often at the end of a single season, without any bees, but in possession of a lot of empty hives. Some valuable but costly experience is the only remuneration obthined It is in such instances that beekeeping is pronounced a failure when, in reality, the blame rests on the operator. To be successful in beekeeping one must make up his mind to go slowly, be willing to read, and think and study, and be content with only a few colonies until experience permits an increase in numbers. It is the really interested. energetic, industrious, and hustling person, who has his inind on his business, studies everything pertaining to the subject, observes carefully and does things, that will make a successful beekeeper in the truest sense of the word.

TIIE STUDY OF GOOD BOOKS.

The very first thing that should be procured is one, or more, books on beekeeping, which should not only be read, but studied to becomp well posted, or "book learned" as some call it, before gettins" th" hees. This will familiarize a beginner with the mysteries of th. hives and the care of the bees and the appliances required, and fit hin to intelligent]y undertake apj(‘ulture when bees are procured.

Besides the laren number of books on heekeeping there are publishe numerous excellent he journals, Often the information gained from a single article is worth more than the pricr of a yoar's subscription All beekeepers of any importance sulswribe for not only one, but se eral, bee journals, as it is impossible to keep up with the timus un make a suceess of the business without reading them. For this re son, it is always adrocated that at least one or more bee journals if subseribed for as swn as, or "ven before, the beos are olutaincert, in all dition to gutting books, as already arlviced. 
A profitable way to begin in beekeeping is to visit successful beekeepers and, if possible, arrange to learn under them. It is a good plan to engage with such for a season's work, in order to gain knowledge of the art. It is really the best way to make a beginning.

Above all, it should be remembered that the start should be made with only a few hives and the number of colonies be increased as experience gained will allow. Go slow at first and do not plunge into beekeeping. It does not pay.

It should also be borne in mind that there is not only a bright side to the avocation, but that in it, as in everything else, unfavorable conditions may be encountered and short honey crops, or even failures, may be the result after the very best efforts in some years.

\section{HANDLING BEES.}

Persons not acquainted with the habits of bees will feel as if the most important thing to have before getting the bees is a suit of armor. This is not as important as many persons imagine; but, with most bees, proper protection of the face and hands is decidedly desirable; and, although some experienced beekeepers claim that they never use veils and gloves, they are to be recommended, especially for beginners, to guard against mishaps that might end seriously. Some races of bees are more easily handled than others and some persons find all bees hard to manipulate, which is more a fault of theirs than the bees. Persons who are naturally afraid of bees incite their anger to a certain extent by their actions, while those who show no fear are rarely ever stung. Patience, care and good judgment are necessary in managing bees to advantage. The best time to handle them is during the middle of warm days and never at night or during cold or wet days, unless absolutely necessary. All that is required is

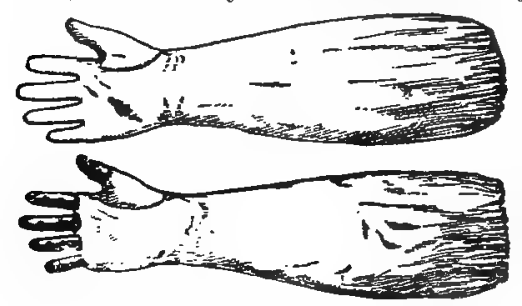
a good smoker and a good veil to protect the face. It is not so necessary to wear gloves, and it takes but a short time to acquire sufficient confidence to run the risk of a few stings on the hands rather than have the inconvenience of any covering that interferes with the free use of the fingers. For the beginner, or timid person, cotton gloves with long wrists are preferable. These are made with, or without, fingers and, while not absolutely sting proof, are cheaper and more comfortable than rubber gloves.

A good smoker is the most essential equipment for handling bees. The smoker, in which dry rotten wood, the best fuel for smoke, has been started with some live coals, or a match, is used to frighten the bees and cause them to fill themselves with honey, after which they are not inclined to resent disturbance. As the hive is approached, a little smoke should be blown in at the entrance, then a little under the cover as it is raised off, when a little more, from time to time, as the bees are handled, will enable one to examine every part of the hive. Too mulh smoke must not be employed. It should be used at the right 
time, in which event very little will be needed. While the smoker is not in actual use it may be held between the knees so as to be in easy reach when required.

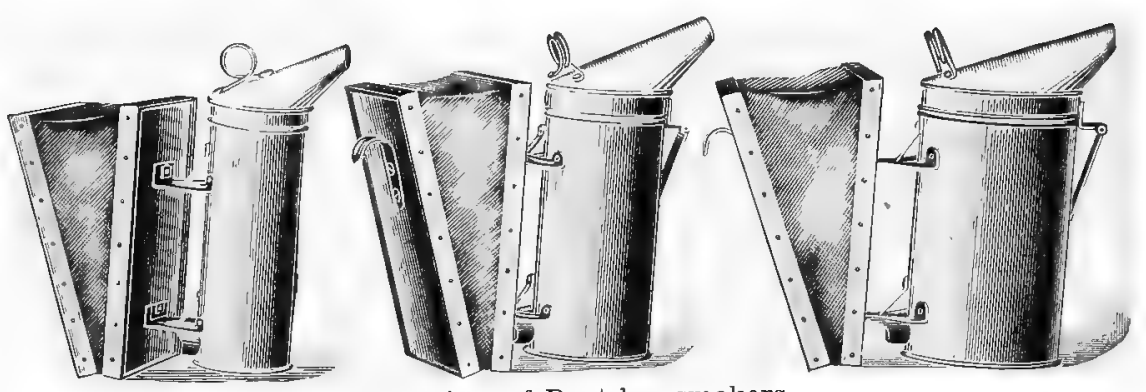

Three sizes of Root bee smokers.

Various kinds of veils are used, according to the individual taste of different beekeepers. Cotton tulle is much used for such veils; those with an elastic cord in the top to go over the hat, and another in the bottom of the veil, to go about the neck, being most generally

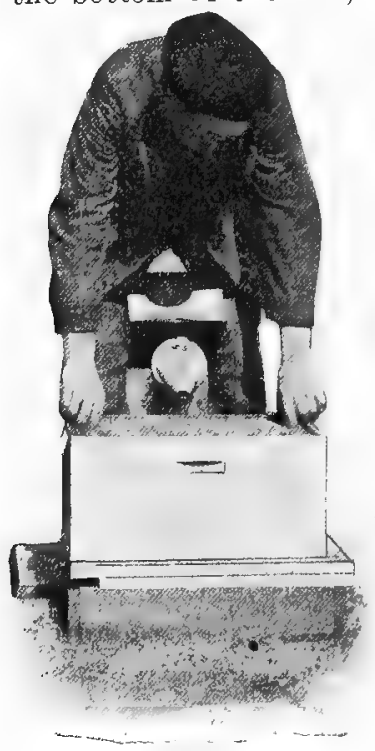

Always in easy reach in case of an emergency. preferred. A permanent "bee hat" is made by sewing the veil about the brim of a large hat. Silk material is also employed for bee veils; but, since it is more expensive and easily torn, only a small piece of it is usually sewed up in the front of the cotton tulle veils, as one can see through this finer material much better. For a more permanent bee hat wire screen cloth is much utilized, sewed to the hat and with an apron of cloth on the lower edge to drop over the shoulders. A width of cloth may also be sewed to the upper edge, in place of the hat, and this provided with a rubber cord to go over the crown of the hat. No matter what material is selected for the veil, it should be black in color, as it is the only color which does not interfere with the vision, especially in sunlight.

It is not only not advisable for the beginner to try to handle bees without protection to the face, but every beekeeper should use a bee veil, as a number of stings in the face are not only unpleasant, but may, under certain conditions, produce bad results when least expected. Bee stings are very disagreeable, but how to avoid them, to a certain extent, may soon be learned. A few stings are inevitable, and a person may become more or less immune to them, so that they will not produce any swelling. While they do not affect some persons, others are given much pain and swelling. 


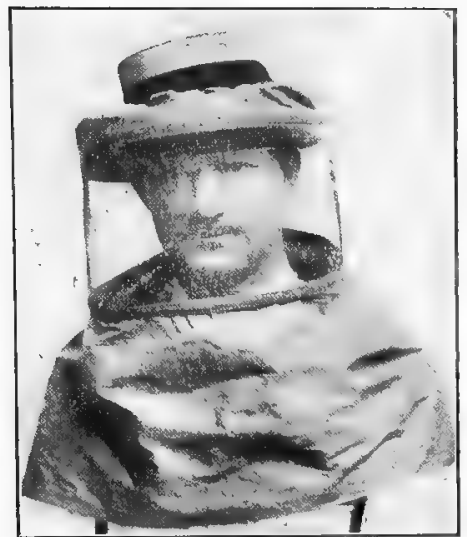

Muth's ideal wire cloth veil.

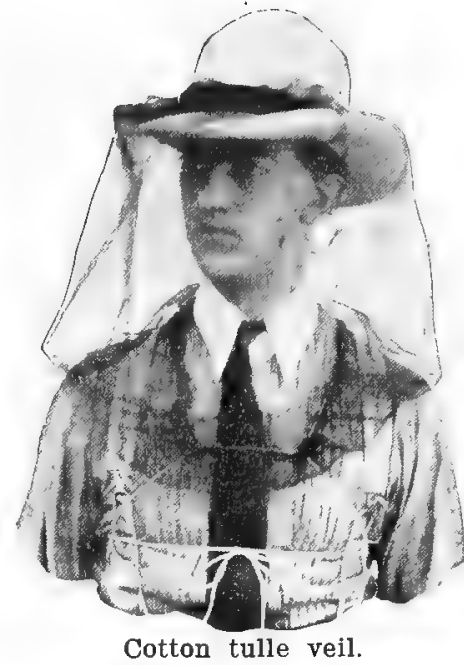

The first thing to do with the sting is to remove it carefully by scraping it out with a knife blade, or the finger nail, in such a way that the poison bag, which is attached to the sting, is not squeezed and the contents forced into the wound. The best care for a sting is to forget all about it as soon as possible. The application of ammonia and other remedies supposed to neutralize the poison are, in most cases, useless, as they can not enter the wound because it closes immediately from swelling. In severe cases inflammation may be reduced by wrapping the affected parts in cold, wet cloths, or bathing with ammonia.

As bees seem to resent dark colored objects, especially black hats and clothing, upon which they pounce much more vehemently an $\mathrm{I}$ sting with greater fury, light colored clothing should be worn by the apiarist in his work with them:

\section{THE FAMILY OF HONEY BEES.}

In order to better understand the necessary manipulation in the successful management of bees, a somewhat general knowledge of the life-habits of the inmates and the economy of the hive is of great advantage.

Honey bees belong to the family Apidae, long-tongued bees, one of the families of the order of insects of which bees, ants and wasps are the most prominent members. There are many members of this family-some solitary in their habits, living alone and making their own nests; some living as guests in the nests of other bees, and some social bees living in colonies, a trait which is a distinguishing characteristic of the honey bees, with which we have to do. The scientific name of the honey bee is Apis millifera, to which the many races, or varieties, the German or Black, Italian, Carniolan, Cyprian, Holy Land, Caucasian and other bees belong. 
A normal colony of bees consists of several thousand to upwards of sixty thousand worker bees, a few hundred drones, and one queen, or, more correctly speaking, the mother of the hive. The queen is a fully developed female and lays the eggs from which all the other inmates of the hive are born. She is capable of laying eggs which produce either drones or workers, and is probably able to control fertilization of the egg which determines sex. Many more worker eggs are laid, which are always fertilized and are deposited in worker-size cells in the combs, while the drone eggs, very much le-s in number, are unfertilized eggs usually laid in drone-size cells. Under certain conditions, they may also be laid in work'r cells.

\section{WORKER BEES.}

The great mass of the memhers of a colony are worker bees, whose duties are to defend the hive, for which they are each provided with a sting; to clean and ventilate it; to rear young; to gather food and water, bee glue or propolis; to sterete wax; build comb, and attrnd to all necessary work of the hive. The worker bees are undeveloped females. Their female organs are not as fully developed as those of the queen; but, under certain conditions, they may lay eges, whirh. however, produce only droncs. These bees are known as "laying workers," and the condition under which they appear is when a colony is hopelessly queenless for a long time and the bees have no way of rearing a queen. Certain workers then begin to lay eggs, with the hope of restoring the colony. The egg laying of these workers is very irregular and seattered about the combs, with several, to a large number of, eggs placed irregularly in each cell. This, together with the drone brood in the worker cells, which can be easily distinguished

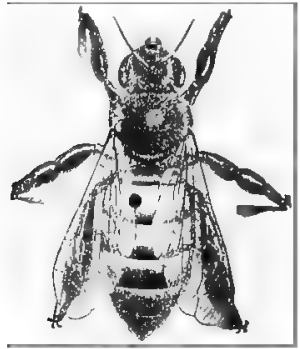

Worker Bee. by the drone brood cappings which stick out from the combs like little hemispheres, unlike the nearly flat capings of normal worker brood, is a good sign of the presence of laying workers. However, the oceurrence of more than one egg in a cell is not always a sure sign, as a good queen may put several eggs in a cell when first "ommencing to lay, or early in the scason. but only for a short time, after which they are laid in the most regular suceession in each cell.

The fact among bees that virgin queens, laying workers, and even fertile queens can lay unfertilized eggs which will live and produce drones is known als I'arthenogenesis, reproduction without fertilization, found among many forms of insert life.

\section{DEVELOPMENT OF BEES.}

There are three stages of development, or metamorphosis, in hees, as with all insects, before the fourth stage, or final grown insect, is reached-the egg, larva and pupa. The egg, very small and oblong in shape, can be easily seen with the naked eye, adhering by its smaller 
end to the bottom of the cell. In three days from the time the egg has been laid it hatches into a very small white larva, or grub. As soon as the larva has hatched it is fed by nurse-bees on a milky white food known as chyle, which is secreted by the glands in the mouth of the bee. This is fed for the first three days, when it is followed by a coarser, partly digested, food of honey and pollen until the larva

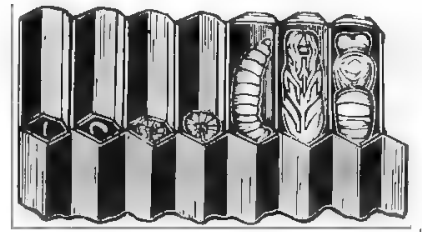

Egg, larvae and pupae: is fully grown. During the first few days the larva lies curled in the bottom of the cell, later straightening out, as it grows, until it lies on its back with its head to the mouth of the cell.

At this stage the bees cap over the cell and the larva spins a fine coccoon within it, and then goes into a quiescent, or resting, period in the course of which a wonderful transformation takes place. During this, the pupal stage, the legs, wings and all other organs of the adult bee are developed, and in twenty-one days from the date of the laying of the egg, twelve days after the cell is capped, the full grown worker cuts a hole through the capping of the cell and emerges upon the comb. Their weak and downy appearance easily distinguishes them from the older bees, who have lost most of the hairy covering from their bodies and look smooth and glossy, besides having more or less ragged wings from flying. The next sixteen days are spent by the young bees in assisting in labors within the hive. Their first duty is as "nurse-bees," feeding the larvae, after which they engage in packing and sealing honey, secreting wax, building comb, hive-cleaning, and guarding and ventilating the hive, during which time only occasional flights in front of the entrance are taken in the warm part of the day. These flights are known as "play spells" of the young bees and are often mistaken by the inexperienced beekeeper for an issuing swarm.

The workers become foragers, or field bees, when they are about sixteen days old, to remain such the rest of their lives, unless through some occurrence, they are needed in the hive for nurse-bees, or other purposes. After carefully marking their location and obstacles on their way to the field, so they may return safely, they gather honey, pollen, propolis, and water. So zealously do they labor that they die in the main working season, from overwork and exhaustion, in about four weeks in the field. The average life of the worker bee is five to six weeks during the working season, though they live longer when there is no honey to gather or little field work for them to do. In the winter, when they are less active, their lives are much longer, extending over several months, the adult's existence being prolonged until young bees again begin to hatch in the spring, when they soon die off entirely.

\section{THE QUEEN OR MOTHER BEE.}

The queen, or mother of the hive, is not, as many suppose, a queen in the real sense of the word, as she does not rule over the rest of the colony. In fact, it is the workers of the body who really govern the affairs of the colony, everything being done by common consent. 
Queens are reared from the same kind of eggs that worker bees develop from, i. e. fertilized eggs, the difference between the two resulting from a special process of feeding the young larva intended for a queen bee and changing the shape and size of the cell into one having considerably more room. The first three days of her larval stage the queen-to-be receives the same kind of food as that of all worker larvae, but the quantity is increased after that time till the little larva fairly floats in the white mass of food called "royal jelly." This change of feeding and the increased size of the queencell develop fully the female organs of the inmate, which would, otherwise, from the same egg in a regular worker cell and with the normal quantity of food, result in a worker bee, or undeveloped female. Unlike the worker bee cells or drone cells in the honey comb, the queen cells are built out from the comb and hang with the mouth of the cell downward, resemble, in their first stage, an inverted acorn

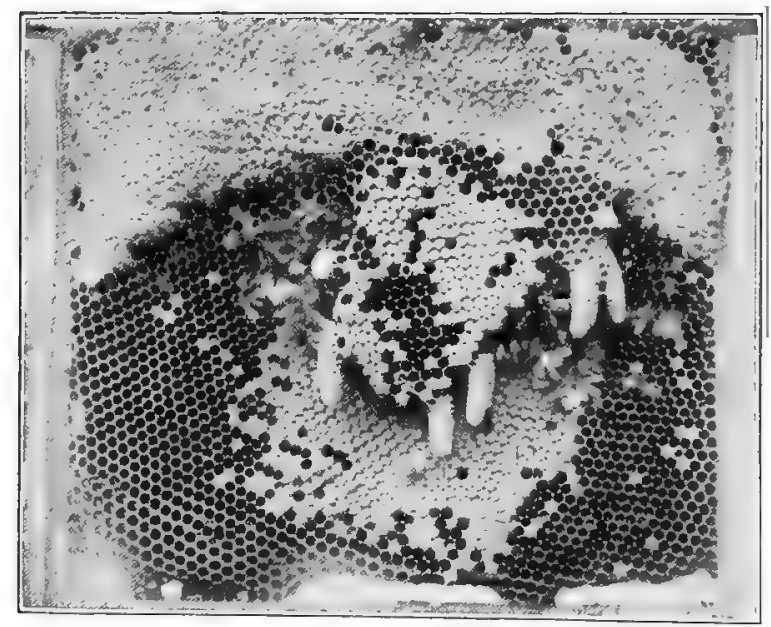

Queen cells built at the bees' own free will.

cup, and later appear rough and very much like the hull of a good sized peanut. Queen cells are built when they are required. They are not always in the hive. During the swarming season and when queens are to be superseded the bees construct queen cells into which the queen lays eggs; but, if a colony is queenless from the removal or death of its queen, the bees build queen cells about very young worker larvae under three days old, by tearing down the walls of surounding cells. From these queens hatch sixteen days after the eggs are laid, considerable longer in size and having more strongly built legs than the worker bees. Their abdomen is slightly longer and their thorax, to which the wings and legs are attached, is somewhat thicker. The first queen that issues from a cell tears down the other queen cells, or, if several queens emerge, the strongest kills them and fills the mother mission for the hive. For the first twelve to twenty-four hours of her age she remains almost unnoticed by the bees as she 
crawls over the combs and eats honey. She diminishes somewhat in size and becomes darker in color in a few days until she is hardly larger than a worker-bee, but very active, and at this time these virgin queens are very hard to find. About the seventh day she leaves the hive for her "wedding flight," to become mated to a drone, which always takes place in the open air while both queen and drone are on the wing. After copulation the drone dies instantly upon separation, as the male organs are torn from his body by the queen when she returns to the hive, and may be plainly seen by the apiarist if he be near. After the seminal fluid is absorbed from the organs, which dry up and disappear, the virgin queen is fertilized, never needing to become mated again, and she now is a fertile queen and becomes a laying queen, beginning to lay in two or three days after mating. She now obtains her full size, resumes her bright color and assumes a majestic appearance, so that she is easily distinguished from amongst the rest of the bees.

If a virgin queen fails to mate she may become a worthless "drone layer," laying only unfertilized eggs from which nothing but drones hatch. Sometimes the young queen may fail to return from her wedding flight, being either caught by some bird, or entering a wrong hive where she is killed by the inmates, leaving her own colony hopelessly queenless as there are no eggs or young larvae from which another may be reared. For this reason a careful examination should be made of such colonies and, if the new queen does not begin to lay in due time, a comb containing eggs or very young larvae from which to rear another, should be supplied, or, better still, a queen-cell almost ready to hatch, or a laying queen.

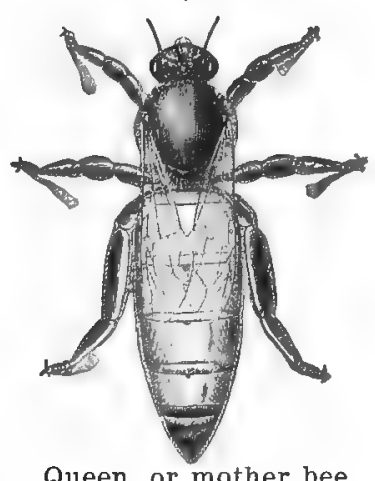

Queen, or mother bee.

Beginning laying only a few eggs a day, soon after fertilization, or at the beginning of the season, the number laid by a queen increases daily until the height of the season, the latter part of April or in May. More than 2,000 eggs may be laid during a single day for a short time, after which a gradual decrease takes place until the end of the laying season, in the forepart of winter, is reached.

Although the queen is provided with a sting she in no instance uses it in stinging, except upon a rival queen. Therefore she may be handled without fear but exceeding care should be taken not to injure her by the pressure of the fingers upon the abdomen, or otherwise. The safest way is to handle her by the wings or about the thorax.

The average life of queens is about three years. They are at their best during their first and second season. Many queens have been known to live four to five years, but it is not advisable to keep very old queens as their feebleness results in weak colonies, due to their inability to keep up the required egg-laying, or in their becoming drone-layers, owing to the exhaustion of the fertilizing fluid in their bodies, received when mating. They are generally superseded by the bees as soon as they begin to fail in their third or fourth year. At 
this time the colony builds cell cups into which the old queen lays eggs and from which young queens are reared, one of which will take her place. It is often that the new queen, the daughter of the old mother, will enter upon her egg-laying duties with her mother still in the hive, and live with her in entire harmony until the old one finally dies. Aside from this condition, no rival queen is tolerated in the hive and when thre are two, or more, a fierce battle ensues immediately in which all save one of the combatants and sometimes all of them receive the fatal royal sting and suceumb.

\section{THE DRONES OR MAT,ES.}

Male bees, or drones, appear in the hives in largest numbers during the swarming season in the spring, when they are needed the most to mate with the young queens, although some of them may be found in nearly all colonies during the greater part of the summer. However, most of them are either killed or driven out of the hives by the bees soon after the swarming season, or upon the approach of a dearth of honey. The length of the life of the drones is therefore very uncertain; several months, if their lives are not ended by the bees or they

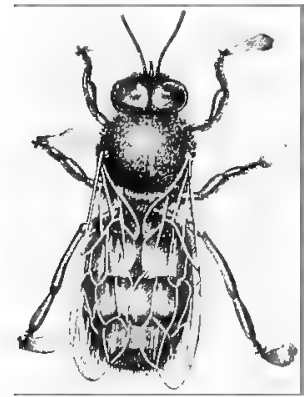

Drone, or male bee. mate with queens. The only function of the drones is to mate with the young queens. Otherwise they spend their time roaming about in the hive in a leisurely, aimless way, not only helping themselves to the honey in the cells, but taking food from the mouths of the nursing worker-bees.

During the warmest part of the day they fly out into the air and their loud, buzzing noise can easily be distinguished. As rirgin queens also come out to mate at such times the drones are quick to give (hase to any that may appear. The mating always occurs high in the air.

Drones develop from unfertilized egos ordinarily laid by fertile queens in drone-size cells in the combs, although as I have before remarked, such eggs are also laid in certain cases by virgin queens and laying workers, both in drone and worker cells, in which event the drones are considerably smaller in size than, but are apparently just as virile as, the normal drones. They develop from the egg in twenty-

four days. Being larger in size and coarser in appearance than the workers, and having a rounded, stubby abdomen, they are easily distinguished. They have no sting.

When drones are overabundant they may be eaught in drone traps and then destroyed. These are

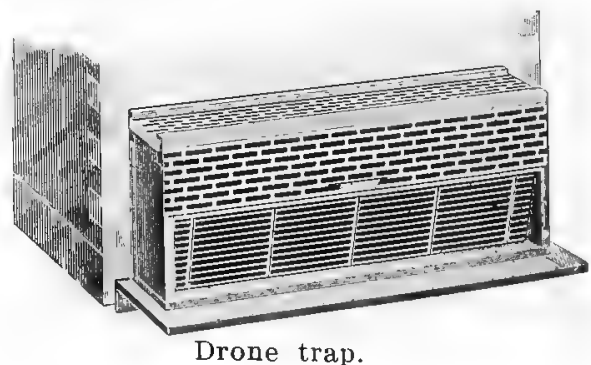

Drone trap. 
set in front of the entrance of the hives and are so arranged that the worker-bees can pass through them; but the drones, being larger, can not. In their efforts they soon find their way, through escape cones in a partition, to a compartment in which they remain confined until relieved by the apiarist.

These traps are also used for catching select drones for queen-mating to be taken elsewhere, and, during swarming time, to catch queens to prevent them from leaving the hive.

\section{RACES OF BEES.}

Quite a number of varieties or races of bees have been tried in Texas and, while all of them possess some good qualities, some have not become popular. Some races are very gentle in disposition, while others are very ill-tempered. This is an important factor to be considered in successful handling of bees. A characteristic of the amiable races is their mild temper when being handled, adhering to their combs as they are removed from the hive and the entire colony remaining in a quiet mood, hardly showing any resentment on account of disturbance and making little effort to sting. This is further emphasized by the fact that many queens of such gentle races continue their egg laying while the combs on which they may be are being held up for inspection, without showing the slightest perturbation. Bees which run all over the hive and drop off the combs as soon as they are picked up are very unsatisfactory to handle. It shows a more nervous character and such bees are much quicker to sting at the least annoyance. The beginner should select a good strain of tractable races, a requisite that means much toward successful beekeeping; and the amateur and advanced beekeeper will find that such races are much more agreeable to have in the apiary.

BLACK, OR GERMAN, BEES.

The common black, or German, bees are still most common in this State, although this race is rarely found any more in its purity in most localities, due to crossing with other races of bees that have been introduced. The result of this continual cross-mating is that most of the bees throughout the State are hybrids. They are a dark race of bees originally brought from Germany. They are rather irritable and more inclined to sting than some of the gentler races. While good colonies store large yields of honey during favorable years, the average is not so good, especially during poor seasons. Besides this and their ill nature, they are poor defenders of their hives against other bees, or robbers, in quest of stores, and the depredation of the wax moth larvae, or "worms," as they are generally called. A valuable trait of the race is that their finished honey combs have a snow white appearance, from the fact that they do not fill the cells quite full of honey and then place the wax cappings, when sealing the cells, well away from the honey. This makes them suitable for fancy comb honey production; but, as a whole, they are considered inferior to other races. 
The queens and the drones are blacker than the gray-black worker bees, and, on account of the habit of this race of bees running all over the combs and about the hives, it does not only make them disagreeable to handle, but makes finding the queens very difficult.

\section{ITALIAN BEES.}

The Italian bees are the most popular throughout the entire country and, as an all-around, all-purpose race of bees, possess more good qualities than any other. They were first imported into this country from Italy about 1860 , and have spread so widely over the whole country that they predominate in nearly all apiaries either in their purity, or their various crosses and hybrids.

There are three varieties of Italian bees. The three-banded Italian, as they originally come from Italy, show three distinct dark yellow, or orange colored, bands on the abdomen next to the thorax. There is a tendency of these bands to become lighter or more yellow in color after the bees have been bred here for a number of years. By ronstant selection of strains showing the yellowest bands, in breeding, bees with four and five yellow bands was the result and those known as Golden Italians originated. These are very beautiful, but are not regarded as hardy as the original type, and, besides, they are not quite as gentle, as a rule, and are more inclined to robbing.

Another beautiful and kindly variety of Italian bees is that known as Albinos. These show rows of unusually distinct white hairs on the rings, or bands, of the abdomen. This variety is not very commonly found, however, and is not superior to the average Italians.

The color of the queens of each of the varieties of Italians varies a great deal. Ordinarily the queens of the three-banded variety have the main part of their abdomen orange yellow and the rest a dark brown and nearly black toward the tip, but a great number have the abdomen of almost a solid color, varying from bright vellow in some queens to a very dark brown in others. As striking as the difference in the color of the queens is, the workers will all show the three distinct bands if in their purity. The Golden queens are almost entirely yellow, or golden, over the abdomen while some show a darker or even a nearly black tip at the posterior end.

The Italians are larger than the German race, and have longer tongues, enabling them to reach the nectar in deep blossoms out of reach of the black bees. Their docile temperament makes them less inclined to sting, but the Italian hybrids are, as a rule, very illnatured. As honey-gatherers the Italians are superior to the blacks in every respect, except in the manner of capping their combs of honey. Their tendency is to fill the cells full of honey to the very top and then place the cappings close to, or right down on, the honey. This gives the surface a watery appearance, rather undesirable for fancy comb honey production. Here in Texas, however, this is not of much importance, since section honey is not produced to any great extent, and, as bulk comb honey is covered with the liquid extracted honey, the manner of cappings does not appear. This trait is less objectionable with most of the Italian hybrids, as a rule, but, aside from 
their combativeness, they are not, on the average, as good honeygatherers as the pure Italians, although many colonies of the hybrids give large vields of honey.

\section{CYPRIAN BEES.}

Cyprian bees were imported from the Isle of Cyprus in 1880. They are somewhat smaller, more active and lighter yellow in color than the Italians. Their abdomen is more pointed and their wings seem larger in comparison to their size. The queens are very prolific and they do not cease egg laying at the approach of a dearth of honey; hence their colonies are always strong in numbers and prepared for any sudden honey flows. In addition to this, they have longer tongues than other bees, and are, consequently, excellent honey-gatherers. They fill their honey cells so full before sealing them that the combs have the same watery appearance as that of the Italians.

A disadvantage is their nervous disposition and, once aroused, they can not be quelled by smoke like other bees. When handling them, very little smoke must be used and, as they resent sudden opening of their hives, or the least jarring, all manipulations must be made slowly and carefully. In spite of this, the operator must expect to receive any number of stings, depending upon the amount of handling necessary. For this reason, more than anything else, this most vindictive of all the races of bens has never become popular.

\section{HOLT LAND, OR PALESTINE BEES.}

Closely related and very much resembling the Cyprian bees is a race of bees from the Holy Land. They resemble the Cyprian in temperament, size and shape, but not in color, the Holy Land bees being somewhat darker and the color of their body hairs giving them a distinct bluish steel-gray tinge. This race of bees has some good qualities. They are prolific breeders, are not given much to swarming, are excellent comb builders, building the most beautiful and straightest combs of any bees, and are good honey-gatherers. Another point of distinction is the manner in which they eap their honey combs. Besides filling the cells entirely full, they lay very thin cappings, for which they use less wax than any other race, right on the honey. On this account the cappings are so slightly attached to the cell walls that they separate from these in perfect six-sided lids very easily when the comb is handled, which leaves the cells uncovered.

But to offset their good traits, they are, like the Cyprians, very nervous and easily irritated. All manipulation of them should be done with great care and with the use of very little smoke, else no amount of smoking will control their onslaughts and they will become unbearable to even the experienced. While some strains are more easily handled, these bees are, as a whole, not popular, except with a very few beekeepers.

\section{CARNIOLAN BEES.}

One of the gentlest races of bees, known as the Carniolans, comes from the southern part of Austria. These bees are large in size, and 
when handled, remain on the combs so quietly and unconcernedly in their activities that the queens may be seen in many instances continuing laying on the combs as they are held up out of the hives. The queens are very prolific and the colonies build up rapidly in the early spring to strong colonies, and, on this account, larger hives than customarily used are necessary. The average hives employed are too small for them and this is, perhaps, the reason why the almost general objection to them as excessive swarmers obtains. With larger hives this may be overcome to a great extent. The Carniolans are excellent honey-gatherers and cap their combs with a most beantiful pearly whiteness.

They are a very dark race of bees, with a nearly black body covered with gray hairs and in well defined rings on the abdomen, which gives them a pretty ashy-gray color. The large queens vary from a dark brownish color to a bronze black, and the drones, which are larger than those of the other races, are of a grayish-black color.

\section{B.INAT BEES.}

This is a comparatively new race in this country. They are closely related and very similar to the Carniolan bees, and, like them, are prolific and breed early, which is an advantage where early honey flows prevail. Unlike the Carniolans, who begin to get the swarming fever about the time the best super work is expected, the Banats, according to reliable authority, are not excessive swarmers aud can be controlled more easily, while they bear being crowled considerably.

The bees are cray, with a tendency toward a yellowish brown in color and, while most of the queens are dark, they vary from an almost black to an orange yellow. In temperament they are very quiet and so easily handled that protection to the face while handling them, in their purity, is hardly necessary. They are fine comb builders, capping the combs very whit. like the Germans and the Carniolans, hence excellent comb-honey builders.

\section{CAUCASIANS.}

This race is of more recent importation and comes from the southern part of Russia. They are perhaps the gentlest bees of all the races brought to Texas and, on that account, promised to become the most popular; but, after being tested extensively by a large number of beekeepers over the State. dill not find mu'h favor, except with a very few. In size and color they resemble the common black bees so much that often eren an expert can not distinguish them, but the marked difference in their temperament is a distingmishing point in such cases. While the Cancasians are prolific and early hreelers, good honey-gatherers, and do not swarm very much, they, on the other hand, have a tendency toward rearing too many drones, to building bur and brace combs in excess and to plastering the interior of their hives considerably with bee-glue, or propolis. On the whole, they are not as good as the Italians. Careful brexling for a number of years by able, experienced apiarists may develop an improvement. 
WHICH IS THE BEST BEE?

This interrogatory is propounded more than any other, and it is somewhat difficult to answer all inquirers alike, since individual tastes vary too much. Taking everything into consideration, the Italian bees are better suited to meet the demands of the majority of beekeepers, and that is why they have come to be the most popular and continue to gain in favor. For best results the three-banded variety should be chosen. If beauty in color is preferred, the Goldens fill the demand. If these do not suit, some of the other races may be selected, and it is for this reason that a brief description of each is given. It is advised, however, to select the Italians, as these are the best all-purpose bees.

\section{BUYING BEES.}

The best time to buy bees is in the spring. If they can not be obtained in modern frame hives, which may cost from four to eight dollars, according to the kind of bees and the condition of the colony, bees in box hives will be the cheapest to secure, and transferring them from these into good hives will give enough experience to pay for the trouble. Common bees in such hives are only worth the value of the bees themselves, the honey and wax in the combs, and the firewood

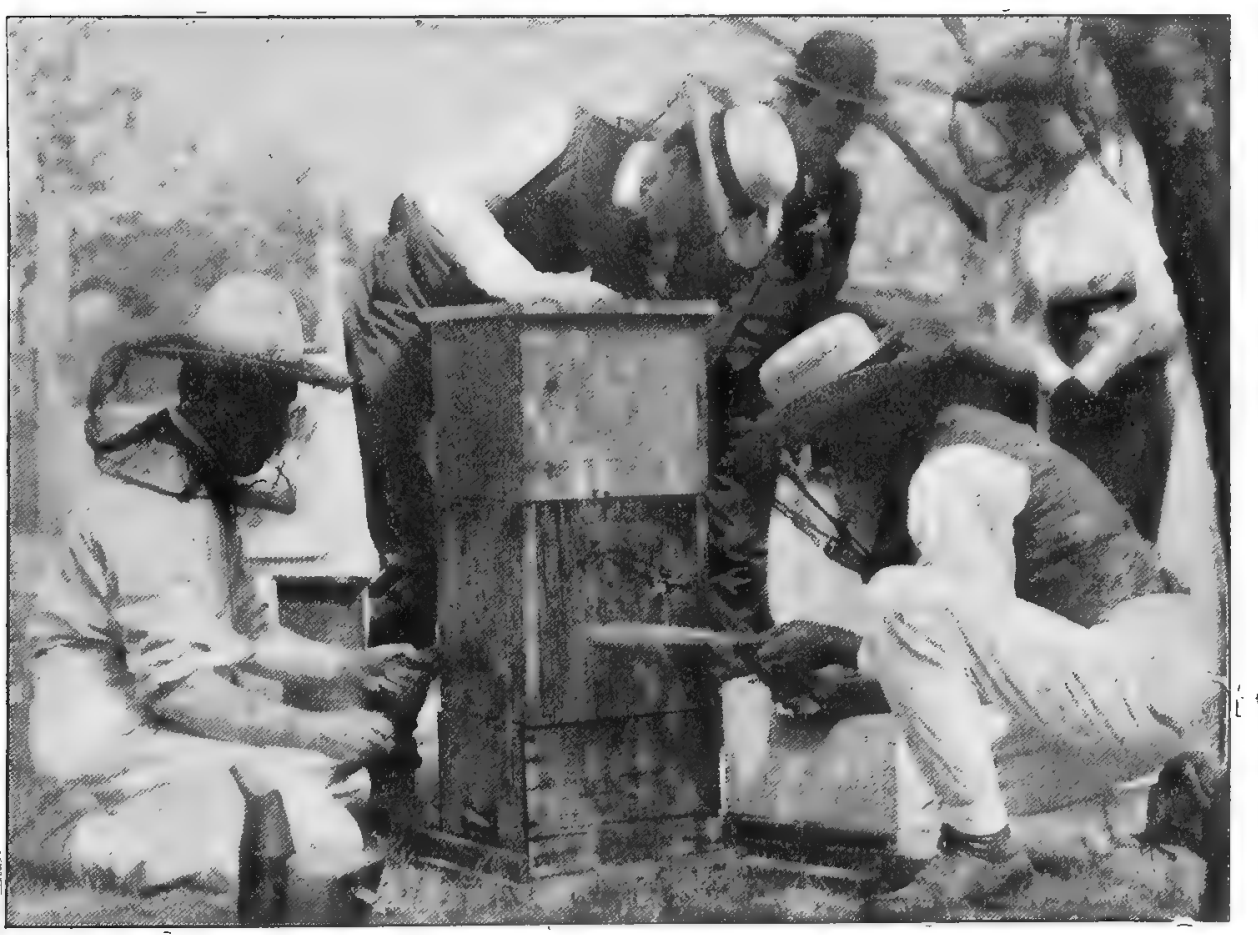

A transferring party. Driving the bees into the inverted box placed over the box hive. 
of the hives, or from one to two dollars per hive, depending upon local conditions, strength of the colonies, the condition of the combs and the ease with which these may be removed from the hives.

\section{TRANSFERRING.}

The best time to transfer them into the new hive is during fruit bloom, when the bees are able to secure enough honey to build up on; otherwise they must be fed a little until they can take care of themselves. To transfer them from a box hive into a frame hive, the usual practice is to remove the colony (after smoking the bees well to cause them to fill themselves with honey) a little to one side of the stand, on which the new hive is set, facing in exactly the same direction as the old one was before. The top of the old hive is removed and over the opening a light box is set with its open side over that of the hive. By gently drumming on the side of the box hive, and also smoking lightly at the entrance below, the bees may be run up into the inverted box, and, when the most of them are in this, making sure that the queen is among them, they are poured in front of the new hive. Into this they will run and make it their new home. A watch may be kept for the queen as she runs in with the bees. A few

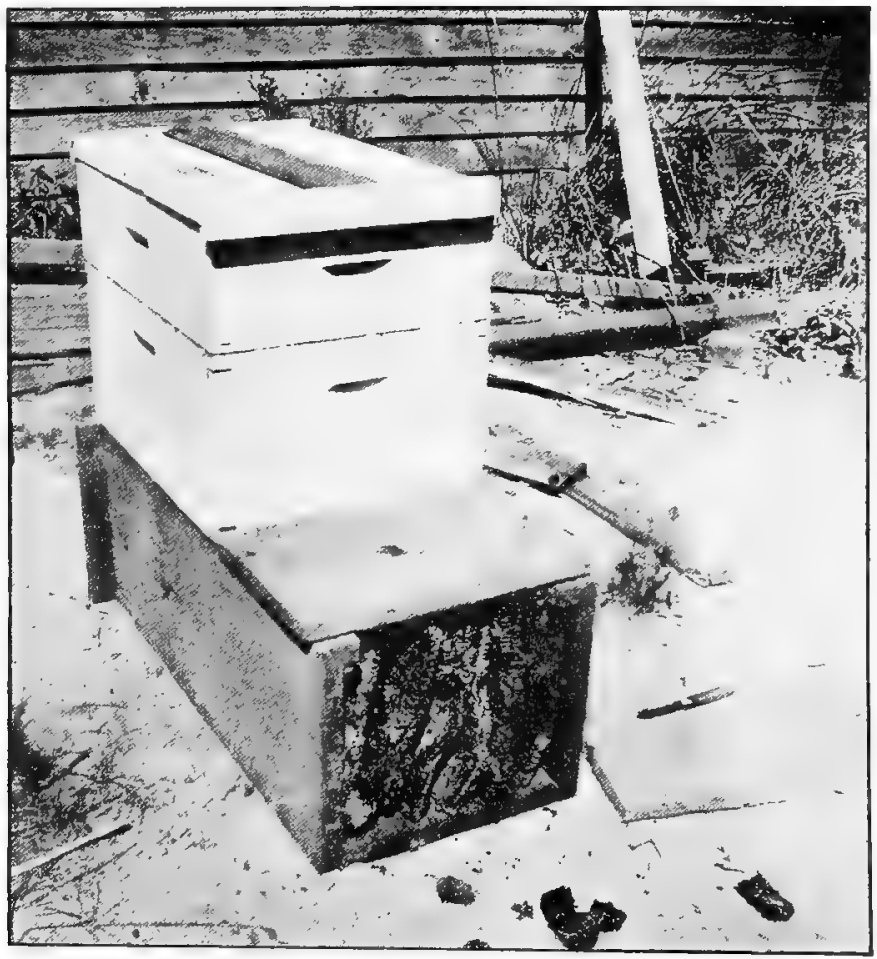

Bees transferring themselves from the old box hive into the new frame hive. 
bees are left in the old hive (more if the weather is cool) to take care of the brood in the combs, which, in twenty-one days will have hatched out and these bees may then, also, be shaken in front of the new hive the same as before.

The combs are now cut out of the box hive and all the straight combs fitted and tied into as many frames as the operator may have comb for, and placed in the new hive where the bees will mend them. Some beekeepers transfer the combs immediately after driving the bees the first time, thus finishing the work at once. This is often the best method when the transferring is done early in the season, so all the bees and brood can be kept together. Other beekeepers do not use the combs at all but melt them up into wax after the bees have hatched out of them in the twenty-one days, leaving the bees in the new hive to build their combs on full sheets of foundation previously fastened in the frames. The box hive is set to one side of the transferred bees in the frame hive and left in this position for ten days when it is set on the opposite side. This throws the flying bees, who miss their own hive, with those in the frame hive. The operation is again repeated in ten days, and then the combs and all remaining bees are removed from the box hive a few days thereafter. This strengthening of the old colony is of material benefit at this time, since the working foree becomes depleted within a short time.

Another simple way of transferring is to lay the old hive, from which one of its sides has been previously removed, on its side and set the new hive, with the frames filled with full sheets of foundation, over it, and allow the bees to move up into it at leisure. As some colonies are very slow about doing this, it is advisable to first remove a large comb of honey and brood from the old hive and insert it into one of the frames, so that the bees will be enticed into the frame hive.

\section{STARTING WITH NUCLEI.}

A very extensive business of shipping one, two, or three combs of honey, brood and bees, in light crates by express, has long been established. Since such nuclei can generally be obtained more easily, and safely shipped a greater distance than full colomies, it is one of the best ways to start with bees. It is possible in this way to begin with pure stock. Such nuclei may be obtained from various queen raisers: whose business it is to furnish both queens and bees of pure strains. Upon arrival of the nuclei, the combs are simply placed in hives previously prepared for them. The remaining space in the hive is filled with frames containing full sheets of foundation, and the bees allowed to build up to full colonies. The nuclei should be purchased at a time in the spring when neetar can be obtained freely by the bees, or the nuclei will have to be assisted by feeding, to enable them to progress.

MOVING AND SHIPPING BEES.

In addition to people simply moving a few "bee gums" home when the first bees are purchased, which is very easily acomplished by setting the box hives upside down in the wagon bed, after having tied 
coarsely woven burlap over the lower open end, and being sure that all cracks from which bees might escape and cause trouble are stopped up, hundreds of colonies of bees are annually shipped over the country for various purposes.

Full colonies of bees are usually moved from one place to another by wagon, by express shipments and sometimes by ordinary freight in entire carloads. One, two and three frame nuclei, or parts of colonies in light crates, as well as bees by the pound in specially prepared screen wire cages, are always shipped by express. In addition to this, queen bees, with their escorts, are sent through the mail to all parts of the world, by the thousands, in small cages made for the purpose.

\section{MOVING BEES SHORT DISTANCES.}

During cool weather of the late fall, winter and spring months, when the bees are not flying very much, their colonies may be moved to any new place without much difficulty. After the bees have been confined for any length of time, they carefully locate the position and the surroundings of their hives when they fly out for the first time, so that they may return to them safely. Suddenly moving a colony even a short distance away, after they have thus marked their location, will result in many bees returning to the old location and perishing there. For this reason, all short distance moving should be done during the winter months, if possible. All that is necessary is to close the hives by quickly pushing a strip of wood, rags, grass or weeds, into the entrances, and then carrying, or hauling, the colonies to their new place. The entrances should be opened only slightly, leaving the obstructions partly in them, to canse the bees to notice the change and mark their new location when they first fly out. As the combs break easily in cold weather, the hives should be handled carefully, to avoid possible clamage.

For moving in the summer the entrances to all colonies should be closed with screen wire cloth, so no bees can possibly squeeze out and cause trouble when least expected. The best entrance closer is a piece of wire cloth, two inches wide, and as long as the hive entrances are wide. This is bent into a $V$, trough shape, and pushed into the entrances by means of a flat instrument, and is easily removed by catching one end and pulling it out. Additional ventilation should be supplied by placing very thin pieces of wood, the thickness of a common match, under each corner of the cover. This should be done when the bees are not flying, preferably very early in the morning. Closing it in the evening may cause stiffocation of the bees during a hot, sultry night.

Thus prepared, the colonies are allowed to remain on their old stands until about $9 \mathrm{a} . \mathrm{m}$., when they are moved, during which process they are to be roughly handled and the bees shaken up considerably. The use of a wheel barrow is preferable if the distance the colonies are to be moved is short, and they should be taken to the new place in a round-about way to increase the excitement. Hauling with a wagon any long distance will stir them up sufficiently to give the desired results. When all are located on their new stands, the entrances are opened only very slightly at first, blowing a little smoke 
over the bees of each colony just before doing so, and as they rush out they will mark their new location and very few will return to the old place. Sometimes many do so, only to soon return to the new place after not finding their hives at the former location. It is important, too, to promptly change the appearance of the old site as much as possible by removing everything that may help the bees to identify it should they return to it. If they do not give up their search, and the number of returning bees is large, a hive with a comb or two of honey, and some unsealed brood, should be placed so they will find it. The nucleus so formed ran then be taken to the new place and united with another colony.

\section{TRANSPORTING LONG DISTANCES}

Bees moved a mile and a half, or more, will not find their way back to their old location, and such moving may be done at any time of the year, with proper precautions.

For hauling bees long distances, especially during warm weather, more ventilation must be provided. This is done by removing the cover of the hive altogether and covering the entire top of the hive with screen wire cloth, tacked over a rim about two inches deep, to allow clustering room for the bees above the frames. Very strong colonies should be given an empty super covered with the screen wire on top of the hive for this purpose. Frames that are not of the selfspacing kind must be securely fastened before moving, preferably by a stick of wood, notched to hold the frames in place, tacked at each end of the hives. The bottom, and all hive parts, and the rims, or supers, covered with screen wire, should be securely fastened together, either by nailing a thin cleat at each hive cor-

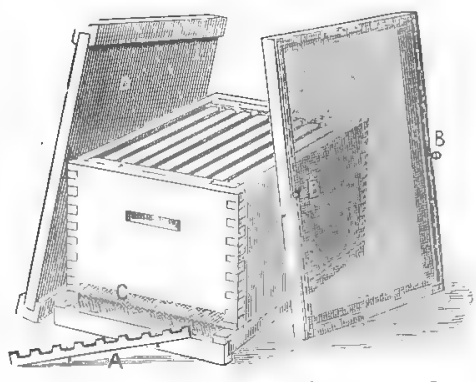
ner with shingle nails, or by means of long crate, or hive staples, which can be secured from supply dealers.

A spring wagon should be used in hauling bees, but an ordinary wagon with a lot of coarse hay in the bottom of it, upon which the hives are placed, will answer the purpose. Driving should be done carefully, especially, over rough roads, to prevent breakage of the combs and possible disaster to the colonies. If many colonies are to be moved, long planks may be substituted for wagon beds. These will serve in place of springs. The hives are preferably loaded so the frames are crosswise of the length of the wagon, as the sidewise jars caused by the unevenness of the roads is worse than the up-and-down forward motions of the moving wagon.

There should be taken along a bee-veil, bee-smoker, hammer, nails, and other tools that may be needed, and the smoker should be kept lighted and going and ready for an emergency. If the bees get too warm and crowd against the screens, water should be sprinkled over them to prevent them from suffocating and the melting of the combs. It cools them and drives them away from the screens. 


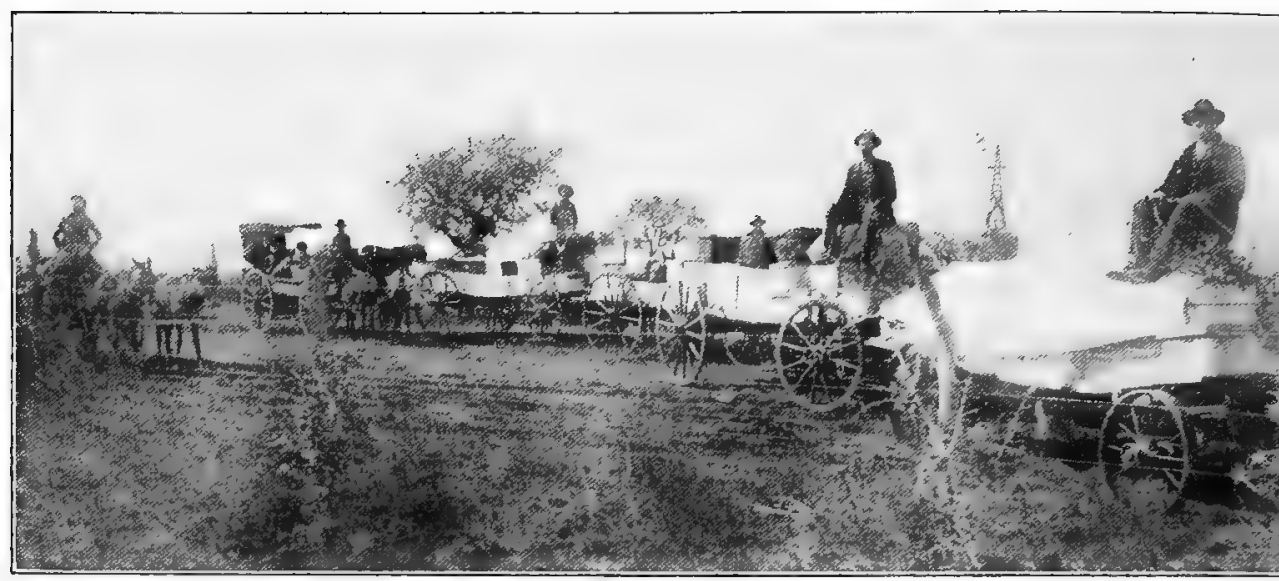

Two hundred colonies on one trip.

HOW TO SHIP BEES.

Small lots should always be shipped by express. They should not be shipped in extreme hot weather, unless absolutely necessary, as the risk of losing colonies by over-heating is great. The hives are prepared in the way already described, by screening the entrances and the entire top of the hives. To prevent damage to the screens over the hives, the covers are fastened over some cleats, tacked on each end on the upper sides of the screens, so an opening, an inch or more wide, and the entire length of the cover, is left between it and the screens, to allow proper ventilation.

While strong colonies will stand shipping with an empty super over the hive instead of the shallower rims of the usual screens used, additional ventilation is necessary in very warm weather. This is provided by replacing the bottoms of the hives with a similar screencovered rim as on top, being sure to nail on two cleats securely, one under each end, to keep the hives at least an inch, or more, from the ground, or floor, to prevent cutting off ventilation. Very populous colonies should not be shipped in one hive at such times, as the great number of bees, crowding against the screens, is sure to prevent proper air circulation and cause smothering of the colonies.

All heavy combs of honey should be replaced by empty, or only partly filled ones, or the honey removed by extracting, as the danger of breakage and the loss of the colonies by the leaking of honey is great. It is only necessary to leave encugh honey to last the colonies for the journey, and, as express rates are high, the lighter the packages are, the better.

One, two and three frame nuclei are shipped in very light cratess, made expressly for the purpose. These are screened both at top and bottom, and have a light cover board nailed to cleats, an inch, or more, higher than the top of the crate. This board is convenient to handle them by, besides protecting the screens, and is also used for the address and the proper precautionary notice of contents and request for careful handling of the bees in transit. 


\section{SHIPPING BEES BY FREIGHT.}

Bees can not be shipped by freight except in carload lots, and at owners' risk, or in smaller lots when taken in an emigrant car with other household goods, when moving to a new location.

The hives are prepared as above described. An open stock car should be used in the summer; while a box car, with the doors partly open is better in cold weather. A man should accompany the car to give the bees necessary attention. In the summer time he should be provided with several square five-gallon honey cans filled with water, and a sprinkler with which to sprinkle the bees if they become too warm and crowd against the screens. One of the automatic compressed air spray pumps, holding several gallons of water, that can be carried by a strap over the shoulder, and the nozzle attached to a short piece of hose, is the most satisfactory for this purpose. With the hose, any particular hive may be reached, especially if the hives are stacked up high.

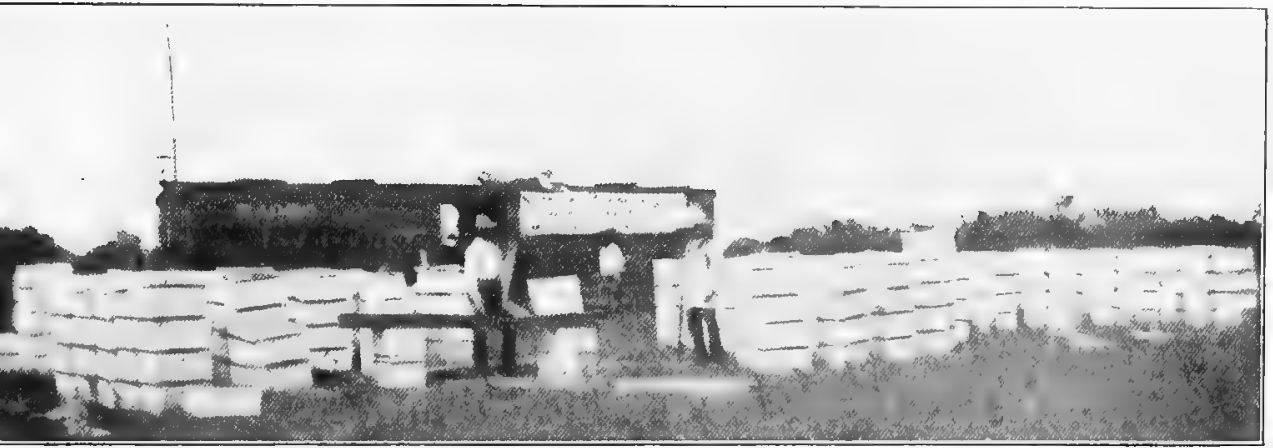

Loading a carload of bees.

The hives should be loaded in the car with the frames running parallel with the rails, as they can stand the bumping shakes endwise, better than sidewise if the frames ran across the length of the car. It should be remembered that this is just the reverse of the way of loading on a wagon. A space of several inches should be left between the tiers of hives, as they are piled up in rows, leaving an aisle between the rows for a passageway. The whole should be braced well, securing the hives in each row, and bracing from one row to another, by means of cross ties.

\section{LOCATING BEES IN THE APIARY.}

Apiary is the proper name of the place where the bees are kept, be there few, or many, colonies. In selecting the site for an apiary the convenience of the apiarist and the welfare of the bees must be considered. A slightly elevated, dry and sheltered location, somewhat protected on the north from the cold winter winds and storms, and open to the south or southeast, with the ground sloping gradually in 
this direction to allow proper drainage, and a sufficient number of deciduous trees for shade is an ideal place to establish an apiary.

The hives should have the morning and evening sun, but should be protected during the hottest part of the day. Shade trees are most desirable for this purpose, as they not only furnish shade to the hives, but the beekeeper, as well, while he is at work with the bees. Those that give a partial shade in the summer and lose their foliage in the winter are the best, while the live oaks and other evergreens, or any too dense shade, should be avoided, as bees do not do well in it. If natural shade can not be had, artificial shade must be provided. Sheds are expensive in first cost, have their disadvantages, and are harborers of insects, spiders and other pests. It is, therefore, better to provide cheap shade boards for each hive. These are easily made of light boards, a few sugar barrel staves held together by a short board nailed across the under side, being the cheapest.

The hives should be set close to the ground so the bees can crawl into them if they fail to reach the entrance on returning from the fields heavy laden; preferably on four common broken bricks, to keep the bottoms from decaying, which can readily be obtained without charge, or at small cost. It is a mistake to place hives upon trestles, like so many are found on the farms. All weeds and grass should be kept down in front of the hive entrances to prevent obstructing the flight of the bees. These impediments and the elevated hive entrances, not only delay them considerably in their work, but many

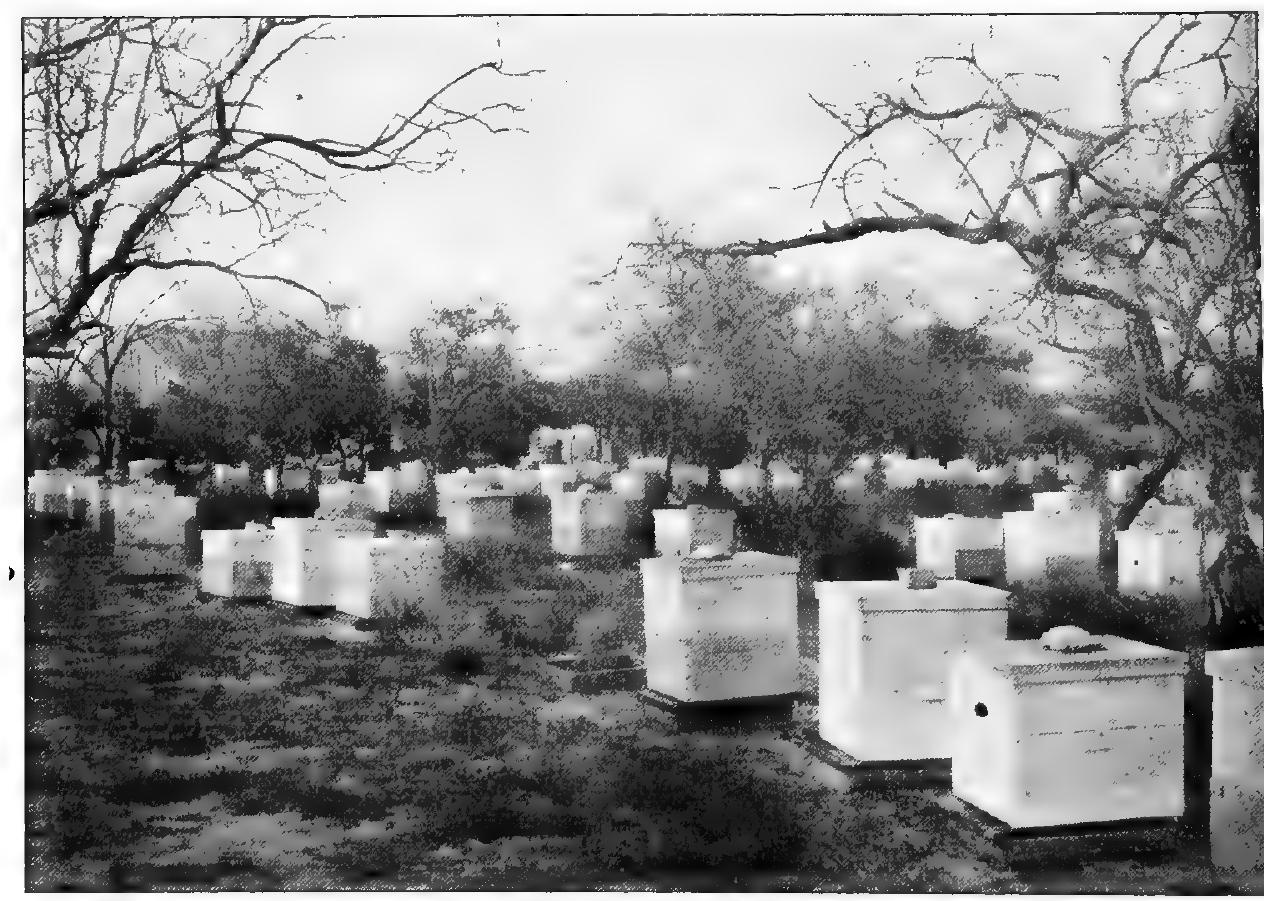

Hives grouped in threes and ground kept clean of grass and weeds. 
will fall to the ground exhausted, and, both they and the fruits of their labors, be lost. The apiary should be kept clean and neat and the bees aided in every way, as they will amply repay their owner for all care given them.

Common coarse salt thrown in front of the hives will aid in keeping down weeds and grass.

The hives should never be set in long rows with equal distance between them, as it results in much confusion of the bees and frequently causes them to return to the wrong hive, on account of looking alike in the rows. The greatest trouble arises from the queens returning to the wrong hives, where they are lilled, and their own hives are then left queenless. If the hives must be in rows they should be arranged in pairs or not more than three placed together, and then the bees will be able to locate their own hive by its position in relation to its next neighbor. The most practical and economical arrangement is to arrange them in groups of five hives in the shade of a tree, so that three hives will face southeast in front of the tree, and, a little distance behind these, one that will face to the left and

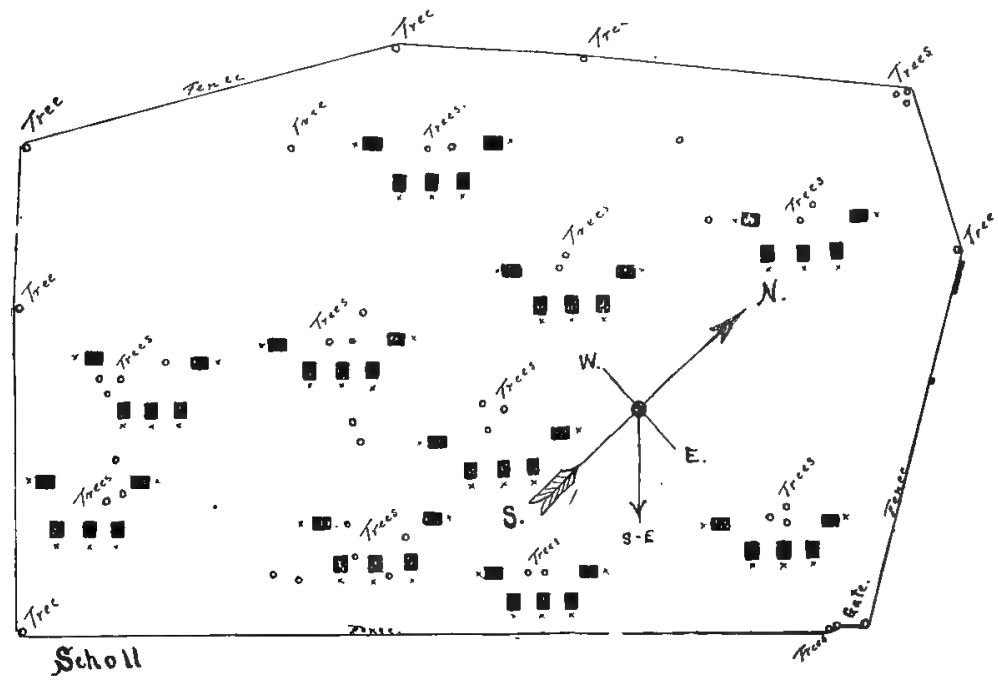

A well arranged apiary plan.

one that will face to the right, with all the entrances away from the tree. This gives a passageway behind the hives, in the main shade of the tree and out of the way of the flight of the bees, making it convenient for the apiarist to work in the shade from the rear of the hives, and use the trunk of the tree to set the hive covers against, within easy reach. It is an ideal arrangement that permits placing more hives properly in a given space than any other; also fewer trees are needed to shade a given number of colonies. Furthermore, it is easier to manage apiaries in groups of five hives in a systematic manner, and the apiarist becomes used to performing many operations on five hives at a time, and saves much valuable time thereby. 


\section{WATER FOR BEES.}

It is most important to have water in easy access of the apiary; first, because bees need a great deal of water, especially during the broodrearing season, and, second, it is advisable to keep them from watering at neighboring troughs, springs or wells, where people are not accustomed to their presence, and may, therefore, be annoyed by them. They prefer natural watering places, and a stream, lake or pasture tank, are good places near which to locate an apiary. Where such a situation is not available, water must be provided for them in the apiary by means of a trough, in which a float, to prevent drowning of bees, is placed; or water can be provided in some other way.

\section{LOCATING OUT-APIARIES.}

Since the amount of pasturage in a locality determines how many colonies can be kept in an apiary, it follows that, after the region is stocked to the limit, a new location must be sought for colonies above the number that can be supported with profit. The new apiaries established under these circumstances are called out-apiaries. The number of them may vary from one to a dozen, or more, according to the colonies owned. The question as to how many colonies may be kept in a certain site can only be answered by the beekeeper himself in the light of his experience, and after studying all the factors involved. Since conditions vary, with regard to such changes, in different parts of Texas, no set rule, as to the proper number, can be given. While a good location will support 100 or more colonies, another, only a few miles away, may be fitted to only one half that number. In most Southwest Texas localities 100 colonies is considered near the proper number, while it has been found that better results have been obtained with only 50 colonies in a place, as localities farther northward are reached. It has also been determined that, in localities where 100 colonies in one place will do well, they would do better if ony 50 were

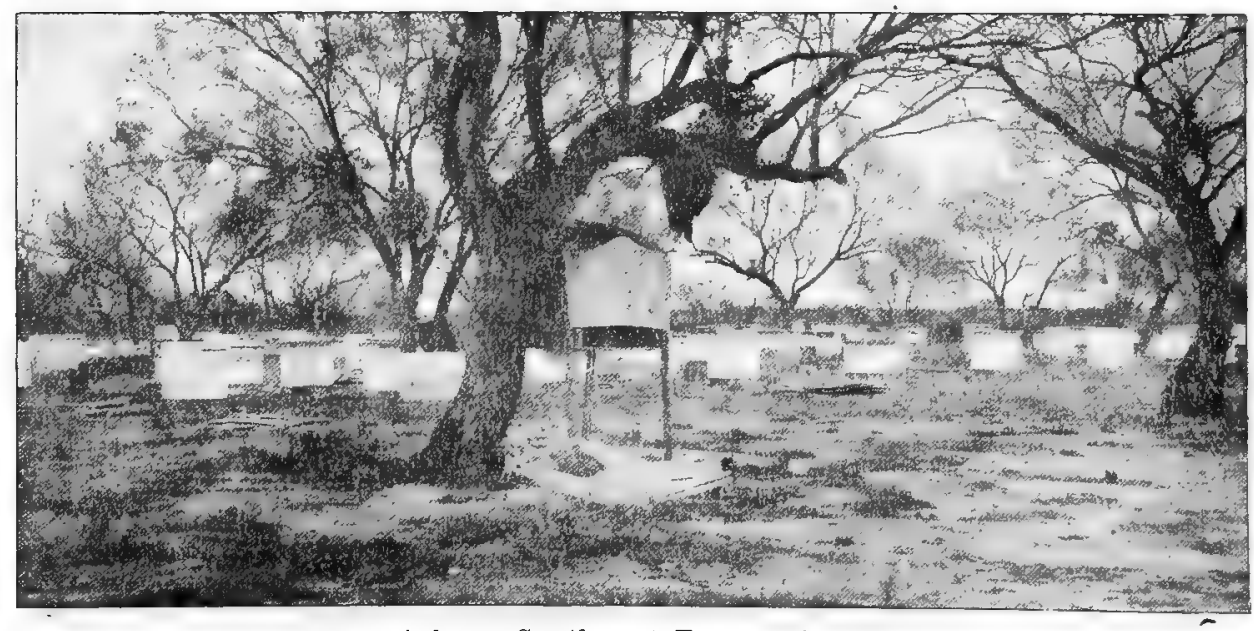

A large Southwest Texas apiary. 
kept in each of two separate apiaries several miles apart. The secret of this is, that the bees are not compelled to forage so far away from the apiary, and thereby waste less time going and coming. There are other advantages, chief among which is (since the difference in locations is so great) catching a possible honey flow at one apiary which may be out of reach of another. With apiaries seattered far and wide, securing honey in some of them is more certain, while, with bees all in one, or the same kind of, location, they may secure none at all, and, as a whole, run the risk of starvinx. Consequently, the
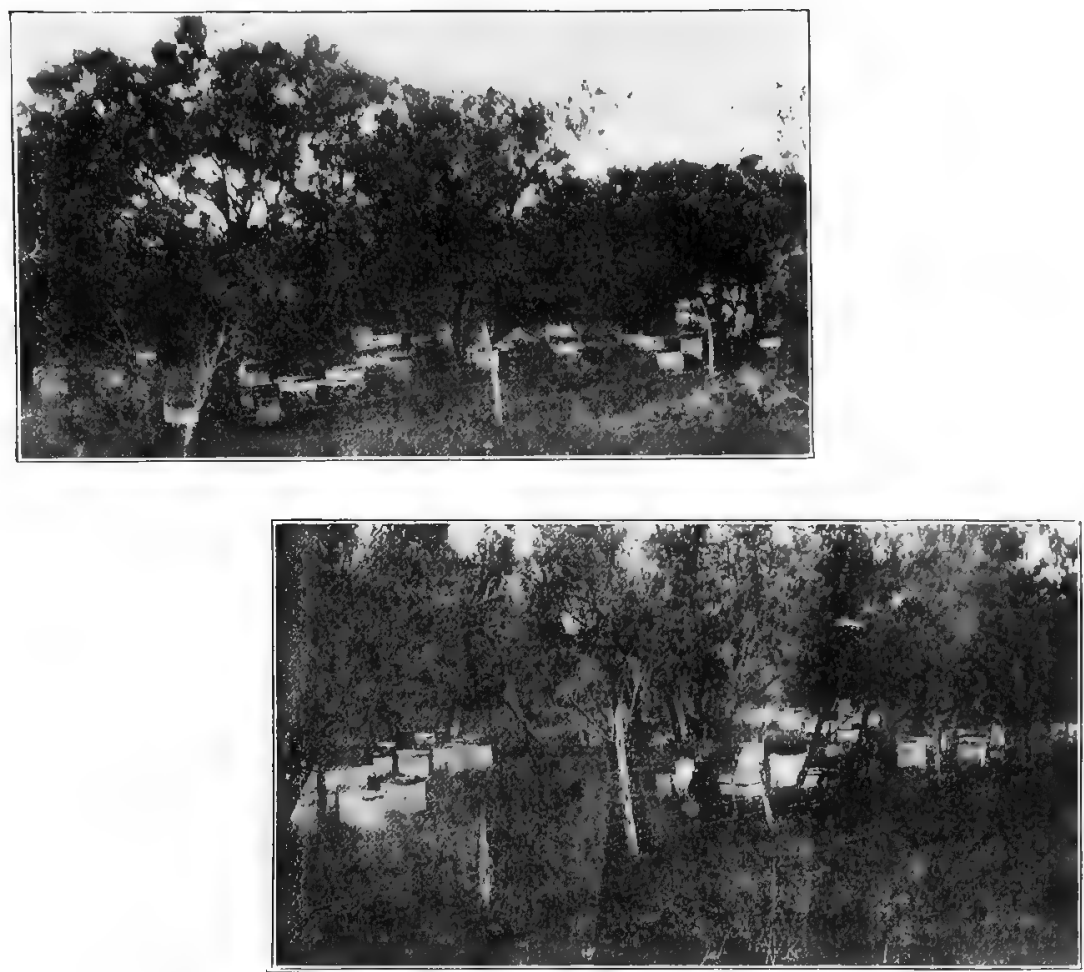

Two fifty colony apiaries.

location of many and smaller apiaries, instead of fewer and larger, has come more and more into practice. Another is that the beekeeper can complete certain work in a small apiary within a short time, and then go to another not far off, before the bees are stirred up to the point of robbing. It is very disagreeable to be compelled to continue the work, when bees are robbing, but such is often necessary with large apiaries.

Ordinarily the apiaries are placed about three miles apart, depending upon the lay of the land, the nectar yielding sources and the locations obtainable for placing the apiaries. Sometimes sites for only a few apiaries may be found in a certain locality, and it becomes necessary, on account of the adjacent territory being unsuited for the pur- 
pose, or already occupied by other beekeepers, to go several miles before reaching a suitable place. The point in view should be to so locate the apiaries that any, or all, of them may be easily reached.

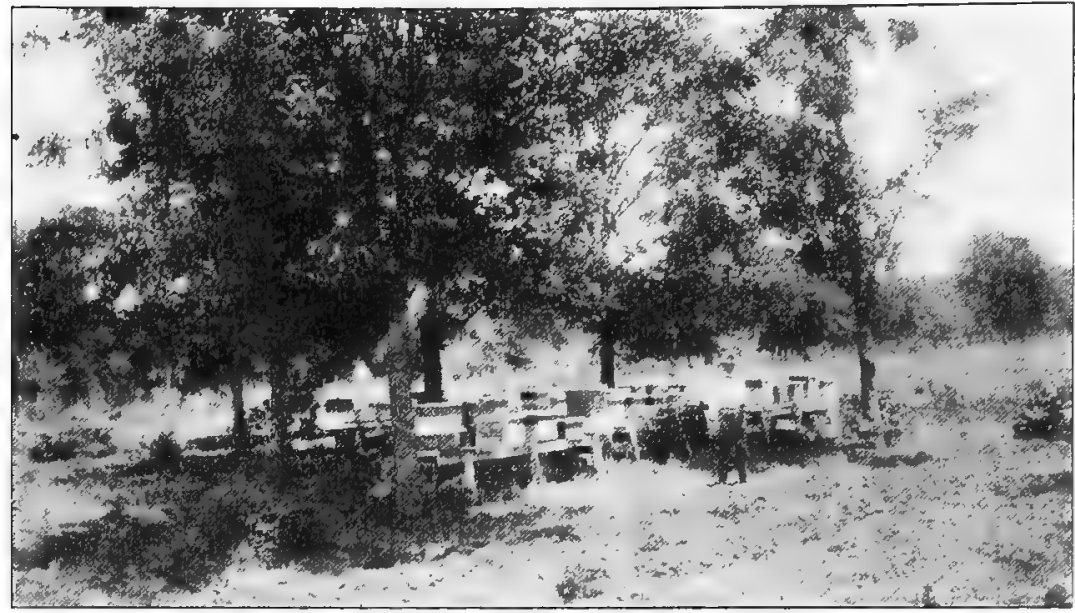

An elevated flood land apiary.

Sometimes it becomes necessary to put them in low valleys and river bottoms, subject to overflow by flood waters, in which evint the hives should be properly elevated upon high benches or scaffolds.

\section{HOW FAR DO BEES FLY?}

'This is another question often asked. Under ordinary conditionbees do not go as far in quest of stores as is crenerally supposed. I'nless compelled to do so, they rarely forage to greater distance than three miles, and that less profitably than if they are not required to.

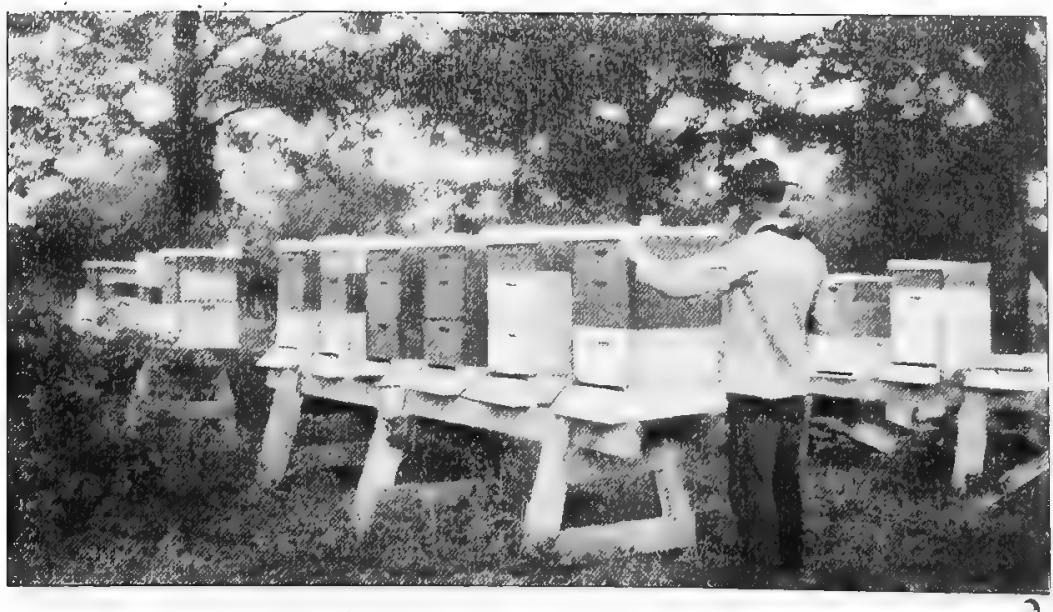

Showing the high scaffolds. 
go so far. It is safe to say that most of the foraging is within two miles of the apiary under average favorable conditions, and in cases where nectar is plentiful they do not go that far. During a scarcity of nectar, bees, in some instances, will go many miles for food, while in others they will starve in their home environment when bees only a few miles away are finding more than a sufficiency of food. These conditions must be watched carefully, or, while the apiarist finds the bees in the best condition in one of his apiaries, those in others may be near the point of starvation.

\section{RENTING OF LOCATIONS.}

There is no set rule as to proper rentals for apiary locations; mainly, perhaps, on account of the varying conditions and circumstances that determine price. While some persons readily agree upon certain terms of pay, others do not care to accept any remuneration for the place the apiary occupies on their property. But the apiarist can easily afford to properly compensate those whose land he uses, because a good location is very essential and a valuable asset in extensive out-apiary management.

As a rule, where apiaries average 100 colonies, a money rent of $\$ 10$ and some honey, varying in quantity according to the favorableness of the seasons, is a fair rental, and one in general vogue. Where only 50 colonies are kept, on the average $\$ 5$ is sufficient. The rental under these arrangements, including the honey donated, will amount to from $\$ 10$ to $\$ 20$ yearly. Where no money rent will be accepted, honey should be donated, a practice of many beekeepers. Some beekeepers secure their locations, and sometimes the entire territory in which to locate apiaries, for a term of years by a lease, and in various other ways.

Out-apiaries should be located some distance away from houses, preferably in a secluded place near a water tank in pastures, where the bees will not molest or be molested. A good fence of smooth wire, to prevent possible damage to running stock, should surround the apiary, and this can often be constructed by selecting a number of trees to fasten the wire to. The land owner is not required to give the bees any attention, the entire management being conducted at long range by the beekeeper, who visits his out-apiaries, whenever necessary. With proper facilities, of which the automobile is coming to be an important factor, the systematic and suecessful management of a large number of out-apiaries is a profitable business.

\section{HIVE EQUIPMEN'T.}

Simplicity is one of the chief requisites of a good bee hive. It may be said that generally the best hive is one that gives most ready access to every part, and that is capable of most expansion and contraction. It must be strongly made of lumber least likely to warp and twist, or check and split, when subjected to extremes of heat, cold, or moisture. For this reason, our native pine is not so desirable as white pine, which is far superior and is almost exclusively used. 
The ten-frame hive, of Langstroth dimensions, is in most general use, although hives of other sizes are also extensively used. For the beginner, the Langstroth hive is advised, since it is considered the standard hive. The main hive body consists of a plain box, $16 \times 20 \times 91 / 2$

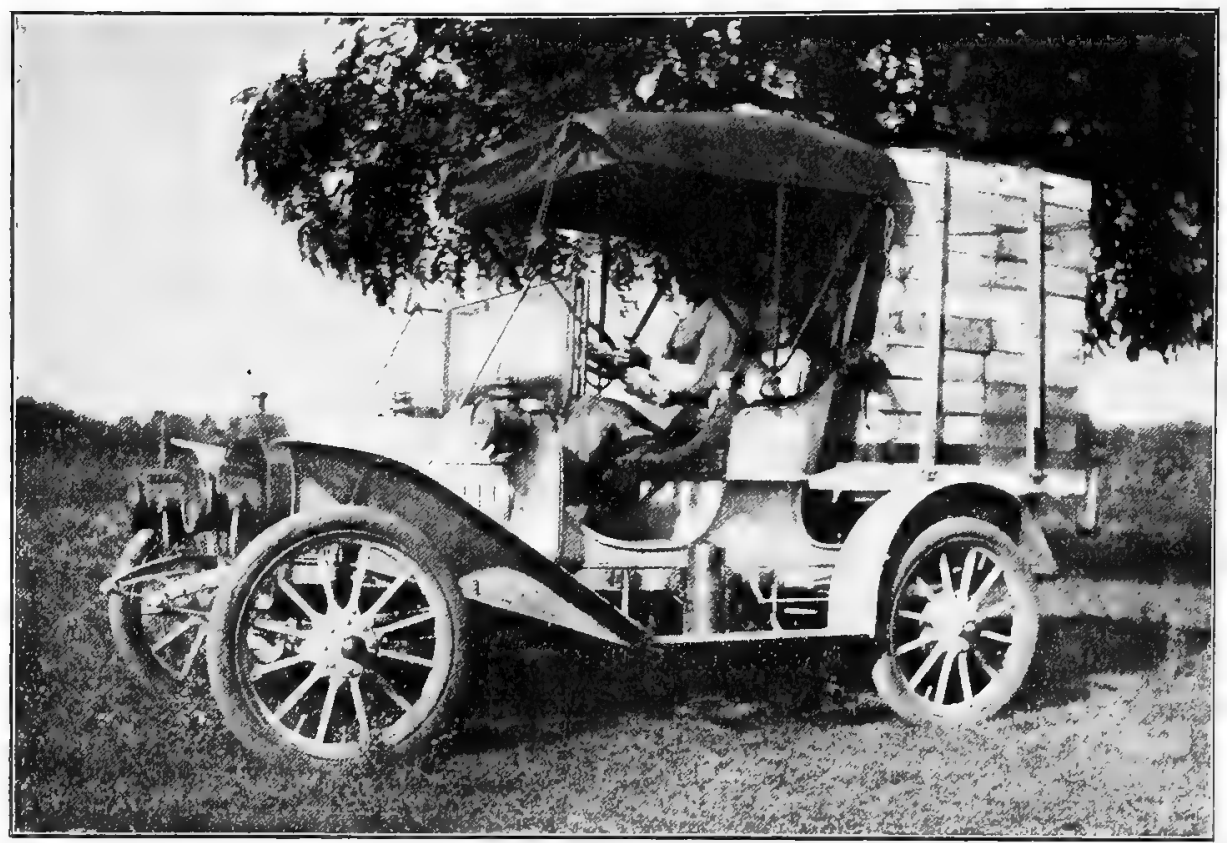

The automobile in the bee business.

inches outside measurement. Inside this hang ten frames, in which the combs are built. These are $175 / 8 \times 91 / 8$ inches outside measurement. The top bars of these frames are 18\% inches long, and extend one-half inch over the outside of the frames, by which they hang in the hives. These projections, or ears, as they are often called, rest in rabbets cut out of the upper inside edge of the end walls of the hive. These rabbets are deep enough to lower the top of the frames exactly one-fourth inch from the upper edge of the hive, and it brings the lower side of the frames almost flush with the botton of it.

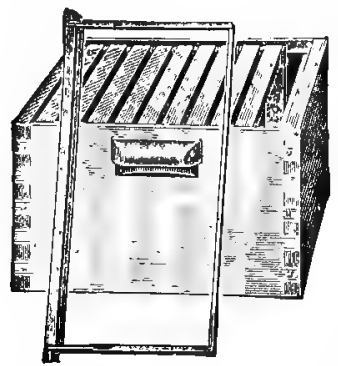

Hive body.

than the bee space.

It will be seen that the frames are of such dimensinns as to allow a one-fourth-inch space between their ends and the walls of the hive body, when these hang in position. This onefourth inch is called a "bee space," through which the bees can pass freely, and it prevents them from glueing the frames to the hive walls. Any space, less than the regular onefourth-inch bce space, will be filled up with "bee glue," or "propolis," a resinous substance gathered by the bees, while they will build honey comb into spaces that are larger 


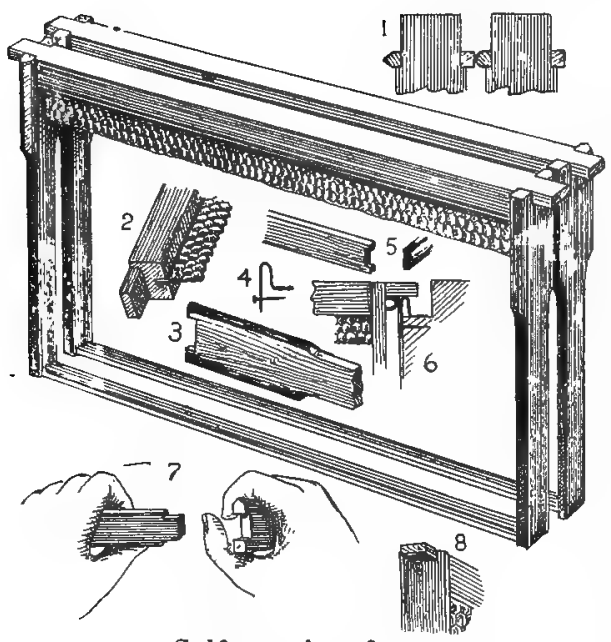

Self spacing frames.

Various patterns of frames are made, but those known as self-spacing frames, such as the Hoffman, are in most common use. As natural comb is found to be spaced $13 / 8$ to $1 \frac{1}{2}$ inches from center to center, the frames must be spaced accordingly, to be spaced right. This is accomplished by making the end bars of such width that, when the frames are pushed close together, the desired spacing is secured. In localities where an abundance of propolis is gathered by the bees, an objection to selfspaced frames is that they are glued together more or less, so that their manipulation is difficult. Spacing with nails, staples and other metal spacers, that allow of an easy separation of the frames, are used to some extent, while unspaced frames are popular with many. The selfspaced frames have first place for the beginner and the general beekeeper, however.

There is no top and bottom to the hive body. These are separate from it, and are differently constructed. The various manipulations and interchanging of the hive
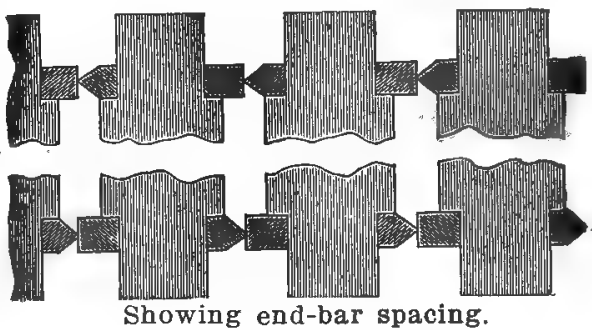
parts afforded by up-to-date hives would not be possible with the bottom and cover nailed to the hive. One of these operations is known as "tiering up," i. e., simply setting one hive body over another; in doing which the nailed-on bottom, or cover, would be in the way. The cover must also be loose, so it can be removed instantly, for rapid examination of the interior of the hive, and to allow putting other hive bodies on top to give the bees more room when needed.

\section{HIVE BOTTOMS AND COVERS.}

The bottom board of the hive may be made of a single board, or several boards held together by a cleat at each end. It should be no wider than the hive, but two inches longer, so as to extend in front and afford an alighting board, or landing place, for the bees. On three sides of the upper surface, cleats, $3 / 8 \times 7 / 8$ inch, are nailed, on which the hive rests, thus raising the frames in it a bee space from the floor. The long opening, left between the two cleats on the sides 

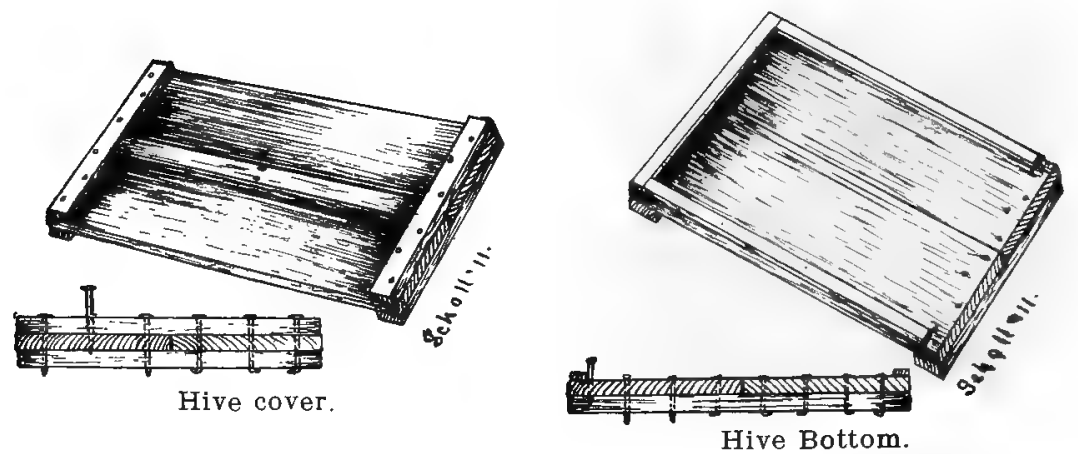

of the bottom board, affords an entrance to the hive, $3 / 8 \times 14$ inches, just right under all conditions, which may, however, be regulated by movable blocks.

A satisfactory hive cover is one of the most essential requisites of a good bee hive. It must be so constructed that it will resist warping, shrinking and twisting, and protect the inside of the hive from the weather and water. There are several good hive covers for sale by the manufacturers of apiary supplies, while others are bad, especially for our severe, hot and dry climate. Tin and zinc may be used in making a good cover, but is expensive. An easily constructed cover is made of two boards, $1 \times 8$ inches, 24 inches long, well cleated together at each end by two cleats, $1 \times 13 / 4 \times 16$ inches. A three-inch batten is nailed over the middle where the boards come together. The under side should be flat and smooth, so the cover will lay flat on top of the hive.

\section{SURPLUS ARRANGEMENTS.}

So far we have described the hive with only its one-hive body. In this the swarm, or colony, of bees occupies the ten frames in which the combs are built, for rearing their brood and for storing honey and pollen or "bee bread," for the immediate needs of the colony; hence this is generally known as the "brood chamber." It is seldom that honey is taken from this part of the hive. The surplus honey is obtained from separate receptacles known as supers-boxes of the same outside dimensions as the hive body, but varying in depth and inside fixtures, depending upon the kind of honey that is to be produced by the beekeeper. Of this there are two kinds: First, comb

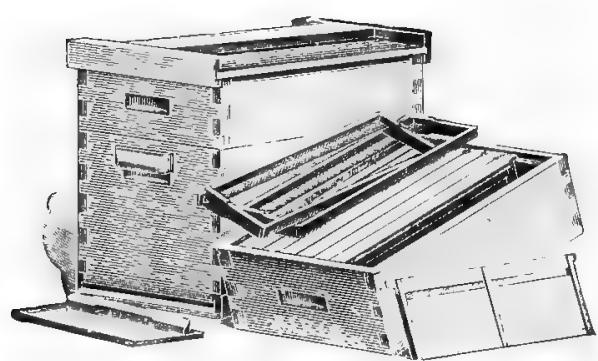

Dovetailed hive with shallow super.

honey, just as the bees build it in the frames, and which is eut out for the market by the beekeeper; or it may be built by the bees directly in small, square pound boxes, or "sections," in which the honey is sold; and, second, extracted honey, which is the same as that stored in the combs of comb honey, but is thrown out of them by means 
of the honey extractor, and the empty combs returned to the hive for the bees to fill again. The supers are placed above the hive body.

For the production of extracted honey many beekeepers use simply another hive body with the same kind of frames as the brood chamber-two, or more, on very strong colonies when necessary. The tendency, however, is toward a shallower super than the regular depth, since these possess certain important advantages, chief amongst which is that additional storage room can be given more gradually, according to the needs of a colony, especially if it is weak, or hampered by the condition of the honey flow, to care for a large amount of room at a time. Another is the ease with which these shallow supers may be freed of bees and removed from the hive when filled with honey. The combs in such shallow frames are more easily uncapped for the extractor by one stroke of the uncapping knife when the honey is to be taken from them.
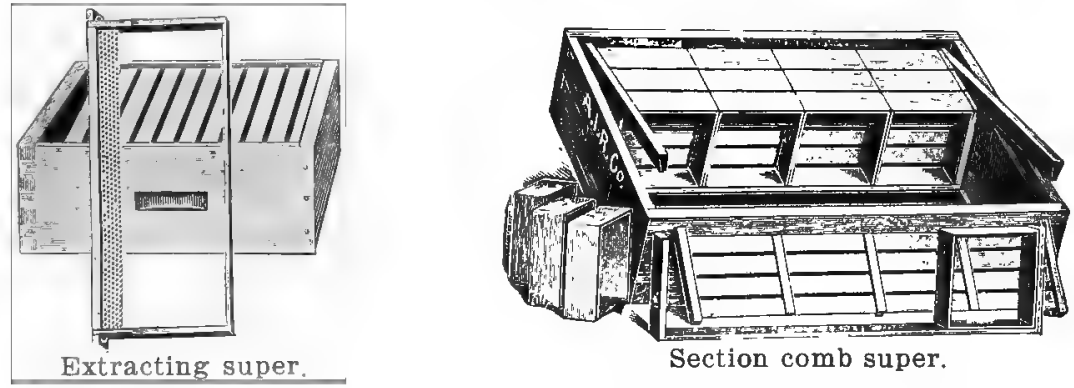

The advantages of shallow supers are especially notable with comb honey supers, of which there are two kinds. Most extenstively used are those 55/8 inches deep, equipped with ten shallow Hoffman frames $53 / 8$ inches in depth. For bulk comb honey production these are unsurpassed. Section box comb honey supers are much more complicated

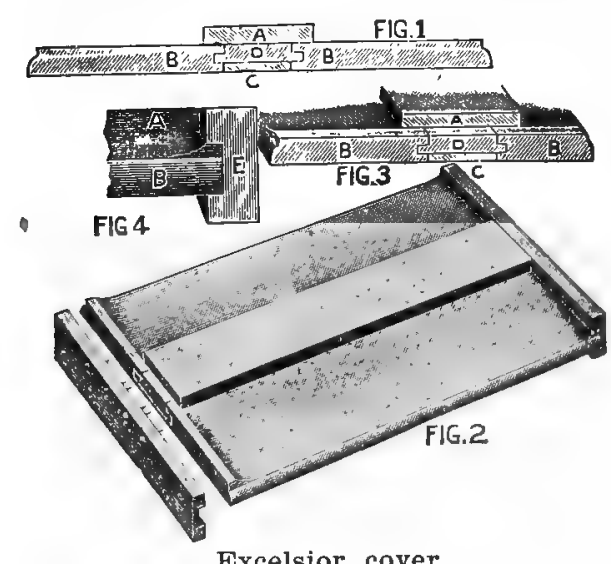

Excelsior cover.

The A. I. Root Co., Medina, O.

highest skill in the beekeepers' in their equipment. There are many styles of these supers, and the best way to get a good idea of them is to procure, from one of the manufacturers of beekeepers' supplies a catalog in which they are described more fully. The most popular of these supers are those with $4 \times 5$ sections and fence separators. Section honey is produced by very few beekeepers in Texas, although it is very pretty in appearance, and ability to turn out a fancy grade of it is considered proof of the art. That Texas apiarists 
do not more largely devote their attention to it is because it requires more laborious work and preparation, and is less profitable. The bees do not build in the small boxes as readily as in the larger frames, and, hence, loss in time and honey is considerable. It is, also, more difficult to ship safely, on account of its being fragile. The losses from breakage and leakage are great, and the difference in price of this and other kinds of honey is not large enough to pay for the extra trouble and cost of production. So little of it is produced that it is seldom demanded, except in a very small way.

No matter what style of supers are adopted, at least three or four should be figured for each hive in use, to allow tiering up, as practiced by all experienced beekeepers. This is done by placing a newly prepared super under one already on the hive as soon as the first one is about half-filled, or more, and the bees need additional room. A third super may be inserted underneath the two if more room is needed, and so on, always providing room for the bees next to the brood chamber, where the bees work best.

\section{MAKE OR BUY HIVES.}

An important question is whether it is cheaper to make the hives and supplies than to buy them "in the flat," the pieces cut ready to put together. Unless one is skilled in the use of tools, the inaccuracies in the spacing of the fixtures in home-made hives will often lead to an indefinite amount of trouble. It is better to buy them ready for use until one is thoroughly familiar with the needs of good hives, and then, if deemed advisable, to attempt to make them. Even then the frames and inside fixtures would better be bought from the manufacturers, who are prepared to furnish them accurately made, since this course is not only the cheapest, but they will fit better in every

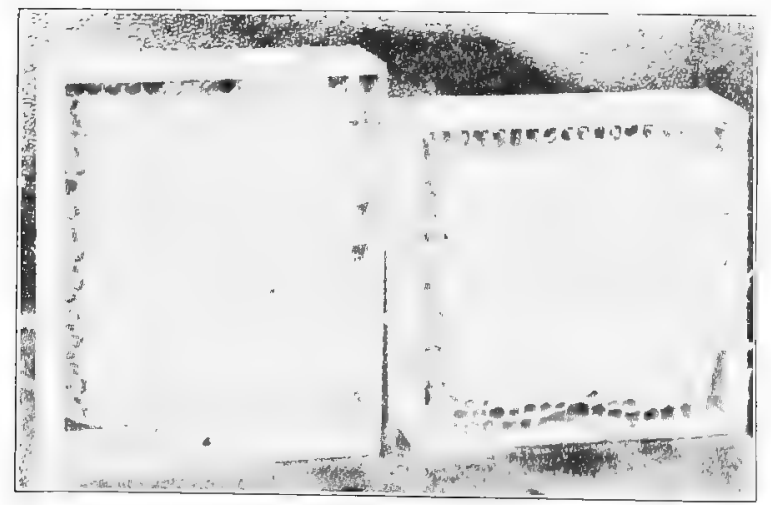

Section comb honey.

way, and thus make their manipulation casier and more agreeable. Not so difficult to make are the bottoms and covers to the hives, and the descriptions and the illustrations will enable any average person to make these quite cheaply. 
WHAT THE BEGINNER NEEDS.

A vexing and erroneous notion of the average beginner, after perusing the pages of a bee supply catalog, is that almost all things needed must be purchased when starting in beekeeping. 'This is not necessary. The start should be made with only a few colonies of

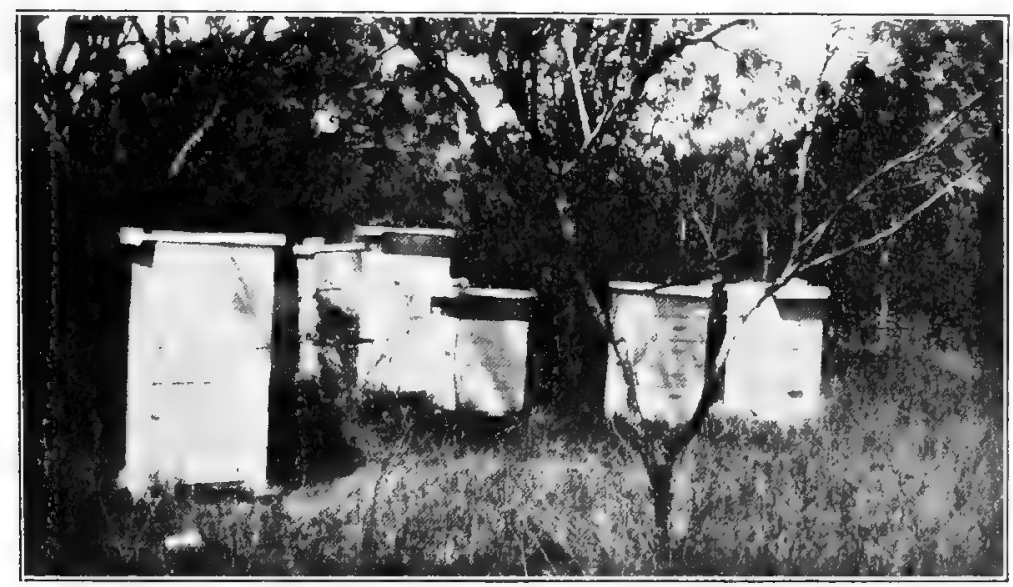

Supers of honey tiered up on the hives.

bees, preferably two or three, and, outside of the hives and frames actually required for these, and possibly one extra hive for each, for the increase, or swarms, a good smoker, a veil, a honey extractor and a good bee book are all that is necessary to buy at the beginning.

If it is desired to produce extracted honey, the honey extractor is needed to remove the honey from the combs. This is a large can in which wire baskets are suspended on a reel that revolves rapidly when turned. The combs of honey, from which the cell caps have been removed, are placed in these baskets and centrifugal force, or suction, forces the honey out of the combs, and causes it to fly against the walls of the can and aceumulate below, where it may be drawn off. As the honey flies out of only one side of the combs, on account of the septum or mid-rib forming a partition, it is necessary to turn them around and revolve again to get all the honey. Before reversible extractors were made, with which the simple reversing of the baskets brings

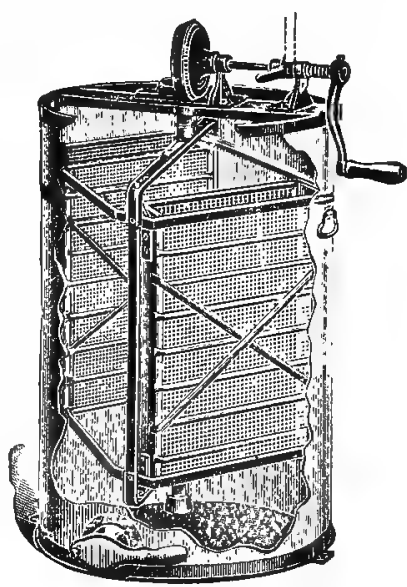

Two frame honey extractor. the opposite side of the combs into place, it was necessary to entirely remove the combs from the stationary baskets, turn them around and replace them in the baskets. 

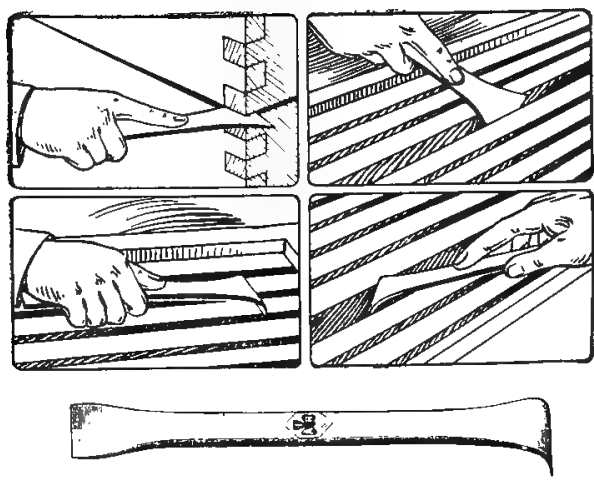

An extractor may be dispensed with the first season if comb honey only is to be produced, but one will be necessary later on -almost surely the next season. By all means, do not omit a good text book on beekeeping, as it is as necessary as, if not more needed than, anything else, for successfully conducting an apiary.

There are many little useful devices that may be added from time to tine, some of which may be made by the beekeeper himself, depending upon his ingenuity. An important instrument is the hive-tool, used for opening hives and prying frames apart. Besides the one shown, a short piece of a buggy-spring blade, sharpened at one end and rounded at the other, is a good one for both prying and scraping. A handy little combination tool box and seat can be made and supplied with hammer, screwdriver, sharp. knife, etc., in addition to the smoker and hive-tool.

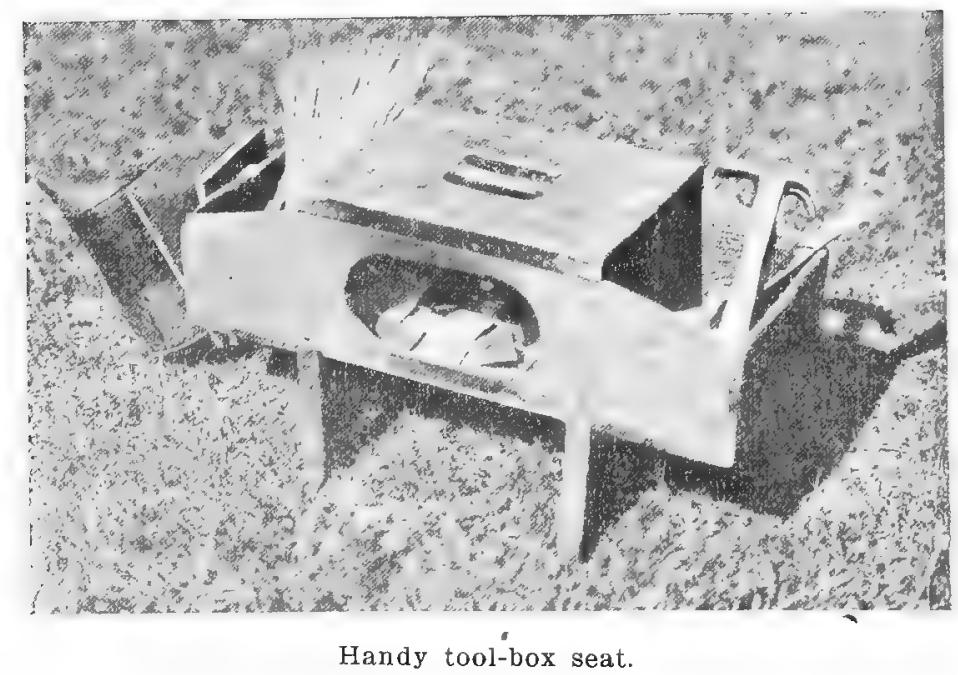

WHEN TU BUY SUPPLIES.

Although all hives, supers and accessories, likely to be required, may be procured from supply dealers at any time previous to needing them, the experienced beekeeper, as a rule, purchases his supplies for the next season in the preceding fall, as he gains several great ad- 
vantages by doing so. Supply dealers encourage this, to avoid the general, overwhelming rush in the spring, and, hence, offer very liberal discounts for early orders. In addition to this, they are able to give quicker service and better satisfaction. Then, too, the beekeeper can devote spare time during the long winter months to putting the supplies together, painting them and making them ready for use when needed.

The general beekeeper has his time taken up by other things when the honey season comes, and, with everything in readiness and in good repair for immediate use, it is not much trouble, and not much time is required, to look after the bees during the swarming time and to give supers as needed. As the supers can be tiered up several high on each colony if necessary, always placing the new ones under those already on, the honey may be removed at any time after the rush of the season. Leaving the honey on the hives improves it in both quality and flavor as it is "ripened," or "cured," over the heat of the colonies, by a process of evaporation carried on by the bees.

\section{PAINTING HIVES.}

Things that are well painted, and kept well painted, will last much longer, and this applies with particular force to bee hives, which are constantly subjected to the weather. Besides preserving them, there is nothing that freshens up the entire surroundings more than a good coat of paint, properly applied to the bee hives in an apiary. Plain white is the color preferred for this purpose, mainly because it reflects the rays of the sun, and the hives are consequently cooler, which is an important item in a hot climate. Besides, a good white paint will give-better results and has more lasting qualities than colored.

The question as to which is the best paint for bee hives is often asked. After trying all kinds of paint and applying it in different ways, I fixd that best results are obtained with a good, well-mixed pure white lead, zine and linseed oil paint. The lead and the oil are the main constituents of any good paint and are often used without the zinc, but an objection to this is that it does not hold well and chalks off after a short time. By adding the zinc, the paint has a harder surface, holds on better and longer and, therefore, is more durable. Too much zine must not be used, as a coat of such paint will soon crack and scale off.

The best way to apply paint is to put a very thin coat on, spreading it out well, and thoroughly working it into every part of the wood. This should be on six months, or more, before the second coat of paint is applied, and when this is thoroughly dry a third and final coat should be given. No other way of painting has proven so durable and satisfactory. 


\section{APIARY MANAGEMENT.}

There are many necessary manipulations that can be profitably made in preparing the bees for the honey season, but many beekeepers tinker with the bees too much. This should be avoided as far as possible, without neglecting the bees. Each individual must study out a system best suited to enable him to get best results in his particular case. In this age of progressive ideas, "short cuts" that aid in accomplishing maximum results are of much importance in the bee business and should be adopted whenever possible.

\section{HONEY FLOWS}

After the bees are located in the apiary in the spring, they should be gotten in the best condition for the honey season. The time of the main honey flow varies in different localities. The spring flow, usually the most important, comes in Southwest Texas very early in April and May, and from two weeks to a month, or more, later in the more northern parts of the State. In many localities there are several main honey flows besides the usual flow in spring or summer. These flows are of varying duration. The beekeeper must learn when to expect them in his particular locality, by studying the flora and times of appearing of blooms from which his main honey flows are procured, or by obtaining the information from beekeepers or others who possess the knowledge, if such, fortunately, happen to be in the neighborhood. The locality should be so studied that the apiarist may be able to foretell from seasonal developments, the commencement of honey flows in his locality. In connection with this, the time to begin preparations for developing the colonies to the greatest possible strength for the flows should be studied also. As bees over two weeks old are the honey gatherers, it should be the aim to have as many bees over that age as possible, and just before the honey flow the hives should be teeming with bees. This preparation is the main aim of the experienced beekeeper who has the end in view of securing big crops of surplus honey.

\section{SPRING EXAMINATIONS.}

Beginning with the first settled warm weather in the spring, all colonies should be examined to ascertain if they have sufficient stores to tide them through the heavy breeding season that will soon be under good headway, and during which time very much honey is required. Needy colonies should receive one or more combs of honey from others that can spare them. In the absence of this, one 
or two of their empty combs should be filled with sugar syrup and given toward evening of a warm day.

Several weeks later a second examination should be made. Spring weather will now be well advanced and the colonies getting stronger in bees. Any colonies that need more stores should be helped as before. At this time all the hives, and especially the bottom boards, should be freed of dead bees and other debris. By setting the first hive on an extra bottom to replace the one to be cleaned, it in turn can be used in the same way on the next hive, and so on through the apiary, saving much time and lifting. The inside hive walls and frames should be scraped clean of burr combs and propolis to facilitate easy manipulation, being sure the combs are replaced the same way in which they were. All drone comb should be removed and replaced with pieces of worker comb or foundation at this time. A close lookout should be kept for any colonies that may be queen. less, and such either supplied with a new queen, or, if too weak, united with another colony.

Since strong colonies in the spring are the ones which produce the surplus honey later, it should be the aim to have all colonies in the best condition possible. Very little other attention need be given them for several weeks, once they are in proper shape, except a third examination, during which rearranging the brood combs slightly, with care and understanding, will stimulate brood rearing and result in stronger colonies. But the beginner should proceed very slowly with this, or he will run the risk of doing far more harm than good. The queen commences egg laying in the middle of the cluster if bees, depositing only a few eggs very early in the spring, and gradually increases the number as the season advances. The eggs are laid in regular order in the cells and in circles around those laid before. From the first comb, this order of egg laying is extended to the others as the bees are able to care for them.

\section{BUILDING UP COLONIES.}

Unlike the general practice of building the weak colonies up by taking both brood and honey from the strong ones, the process should be reversed. As the strongest colonies are the ones that yield the surplus, they should receive the best attention, and, if necessary, be helped at the expense of the weak by taking brood Irom these, as may be required. Weak colonies do not give good results, and those of medium size never yield as large returns as good, strong colonies. Strengthening the weak, at the expense of the strong, produces all medium size colonies, and none of them may be in condition to produce much surplus. This is especially important in localities where honey flows come early, and the time in which to get the strongest possible colonies is short. Therefore, reversing the above procedure produces extra strong colonies that will give results that can not be obtained otherwise, while the weak colonies will take care of themselves.

Combs of honey, may, of course, be taken from strong colonies having an oversupply at any time, care being observed to leave a suffi- 
cient amount, as strong colonies require far more than weak ones. But taking from them combs of brood is different, for brood means bees, and the more bees in a strong colony the more honey, while the same bees given to a weak colony may not be able to gather honey at all.

Where honey flows come late, conditions are entirely different, and the apiarist has ample time in which to build up all his colonies to good strength for the honey harvest. In this case, the strong colonies are drawn upon for both brood and honey to help the weak. Great care should be taken at all times to choose combs not containing too much brood for the size of the colony to which it is to be given. Combs should be selected from which most of the brood is already hatching, as the weak colonies may not be able to care for it properly. These combs should always be placed with the brood as nearly next to that already in the hive as possible, to prevent breaking up the cluster, especially early in the season. It should be remembered that all this work must be done slowly and carefully and with good judgment.

FEEDING BEES.

It is necessary at times to feed bees, either to tide them over a dearth of honey in the summer, to supply winter stores in the late fall, or to replenish their rapidly disappearing food supply during the heavy brood rearing period in the early spring. The necessity for feeding should be avoided as much as possible, since it is a disagreeable and sticky operation, and, as it must be done generally during a dearth of honey, exceeding care must be exercised not to incite robbing. All feeding in the hives should be done quickly, and always toward evening of the warmest days, so that the bees can clean up the syrup during the night and be better prepared to defend their hives on the following day. An excellent practice is to, at all times, leave a sufficient supply of honey in the hives, not only for the winter, but to last into the spring months. Besides saving the trouble of having to feed, the extra supply insures strong colonies for the honey flows and better returns in honcy crop.

It is by far the safest rule to feed sugar syrup instead of honey, especially honey from an unknown source, which may contain germs of contagious bee diseases that may be introduced to healthy colonies and cause their rapid destruction. On account of this danger such should never be used under any circumstances. Sugar syrup for feeding purposes is made of equal parts of sugar and water hy simply pouring cold water over pure granulated sugar and stirring it until the sugar is all dissolved.

If only a few colonies need feeding, some of their empty combs may be filled by placing them in a slanting position in a large tub and pouring the syrup over them with a sprinkling can so that it will run into the open cells. If combs are laid flat, the syrup can not enter the cells as the air can not escape from them when the 
syrup is poured over them. Several styles of feeders are made, of which some are placed inside of the hives, like the Doolittle division board feeder, which is hung in

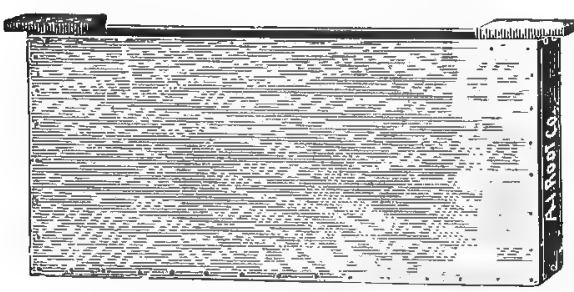

Doolittle feeder. the place of a comb removed from the hive and filled with syrup from the top, after partly opening the hive to do so. Another kind, of which the Alexander feeder is the best, is placed beneath the hive and filled by simply removing a sliding cover block over the opening on the side of the hive. Feeding at the entrance should be avoided, as this often incites robbing by other bees being attracted to the colonies being fed.

Whenever it becomes necessary to feed a large number of colonies in an apiary, a common tub filled with syrup may be placed some distance from the bees, throwing into it a lot of coarse weeds or grass to prevent drowning of bees. It is better to place the feeding tubs some distance from the apiary when out door feeding is practiced, to prevent an uproar and serious robbing. As it is often dif-

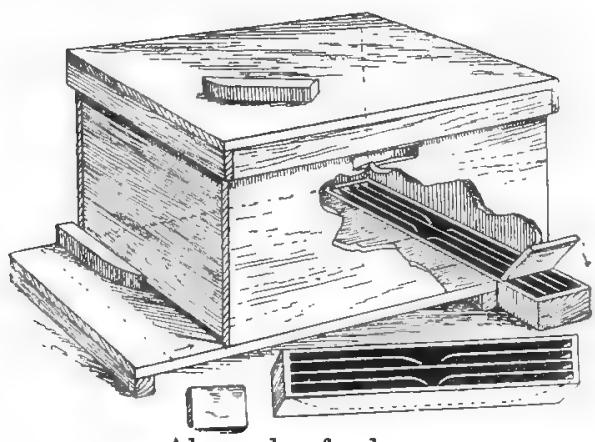

Alexander feeder. ficult to attract the bees to the feeding tubs, an empty comb, that has been inserted into the tub of syrup, is placed at the entrance of each of the colonies from which a goodly number of bees are allowed to gather on the comb. This is then taken, bees and all, to the tub and the bees will soon be started at the work of carrying home the syrup.

Feeding ought not to be done later than November; so as to allow the bees to arrange their winter brood nest in the best possible shap Combs of sealed honey may be given safely at any time, by placing the combs within easy access of the bees, but care must be exercised not to disturb the eluster.

Sometimes, in delayed spring, the supply of pollen may become exhaústed before new pollen can be obtained. Since the bees must have this, as well as honey, to rear brood, it may be supplied artificially in the form of flour, corn meal, bran or cotton seed meal, in shallow troughs placed in some sheltered place in the apiary. As it is often hard to induce the bees to begin taking it home, a little diluted sugar syrup sprinkled over the supply will aid this.

\section{UNITING BEES.}

It often becomes necessary to put two or more colonies together, either because they are too weak in bees to take care of the hive or because they are queenless. On account of a failing queen, or other 
causes, colonies may become materially depleted in numbers, and, unless taken care of by the apiarist, perish. If this condition prevails during the spring or summer, the introduction of a new queen, if this is the cause of deterioration, will aid in building up to strong colonies again. If, however, they already hare a good queen, the weak colony can be strengthened by furnishing them with a comb or two of hatching brood. In the late fall and very early spring this is not practicable, however, and two or more weak colonies should be united. Unless the apiarist desires to select the best queen, this selection may be left entirely to the united colonies. Frequently individual colonies may become queenless at a time when it is not practicable to give them a new queen and the best practice to follow under those conditions is to unite them with a normal colony as soon as discovered.

As each colony has a distinct odor by which the bees recognize their own members from those of other colonies, some precaution is necessary in uniting two or more. A common practice with many beekeepers is to give each colony, to be united, a somewhat thorough smoking, and then simply set one hive on top of the other and allow them to mix at once. Sometimes they may engage in fighting and a second smoking may be necessary. Another method is that known as "the newspaper method" of uniting. A newspaper, through which a two or three-inch hole has been torn in the center, is laid over the top of the colony having the queen. The other colony is then set on top of this, being careful not to leave any opening for the bees to get out except through the entrance of the hive below. The bees above will acquire the same scent as those in the lower hive and unite without any fighting. After a week or two, in either case, the bees may all be put into the lower hive, and the upper one (with its combs) removed, if it is necessary to do this at all.

As bees ordinarily return to their old location when their hive is moved to a new place in the apiary, some precautionary steps must be taken to prevent this. Queenless bees will remain in a new place much more readily. Therefore, the simplest procedure when uniting bees is to de-queen the weak colonies that are to be moved a few days before they are to be united with colonies that have queens. While moving the queenless colonies, the bees should be shaken up and bumped about considerably by handling the hives roughly, as the excitement caused is an additional aid in keeping them where desired. In spring and fall, uniting should always be done in cool weather, if possible, when bees are not flying much or at all. If a few bees should return to the old location, they would be, usually, old bees that would not be worth very much on account of their age, and the loss would be immaterial.

LAYING WORKERS.

To avoid vexatious trouble with laying workers, which is the result of prolonged queenlessness, care should be exercised not to leave any colonies queenless too long. If a queen can not be supplied to 
a colony that may be found queenless, a comb with eggs, or very young larvae, should be given so that one may be reared and the colony saved. If queenlessness is discovered too late, however, the best remedy with laying workers is to unite the colony in which they are found to exist, with a normal colony. As it is impossible to introduce a queen to such a laying worker colony, and they are, as a rule, more or less weak in number of bees when discovered, the most practicable thing to do is to save the remaining bees and the combs. If increase is desired, at a time when such can be done, the united colony may be divided again, and a new queen introduced to the new colony. This method is the most practical way of dealing with this problem.

\section{ROBBING.}

The utmost care and precaution should be exercised at all times to prevent what is termed "robbing," which, when once started, may end seriously if not taken in hand immediately. During a dearth, when nectar is scarce in the fields, the bees continue their search and will appropriate any honey they can find and obtain access to. Once they have an opportunity to get a taste of honey thus easily obtained, they continue to fly around a long time hunting for more. It is far easier to prevent robbing than to cure the trouble, and therefore no honey, or combs, or other sweets, however little, should be left where the bees can get at them. A hive should never be kept open too long and ixposed to the attack of hese prowling bees, who will pounce upon it if they can secure any honey, and will be joined by other bees from their own and other hives as soon as these learn of the find. While strong colonies may be able to defend themselves against such an attack, the loss of bees, during the pitched battle between the inmates and the robbers, is serious, and weak colonies, not strong enough to defend themselves, will be destroyed.

If it becomes necessary to work with the bees in the apiary when robbers are bad, it should be done under a tent made for the purpose. These are variously constructed. One kind much in use, is about five feet square and can be folded up when not in use.

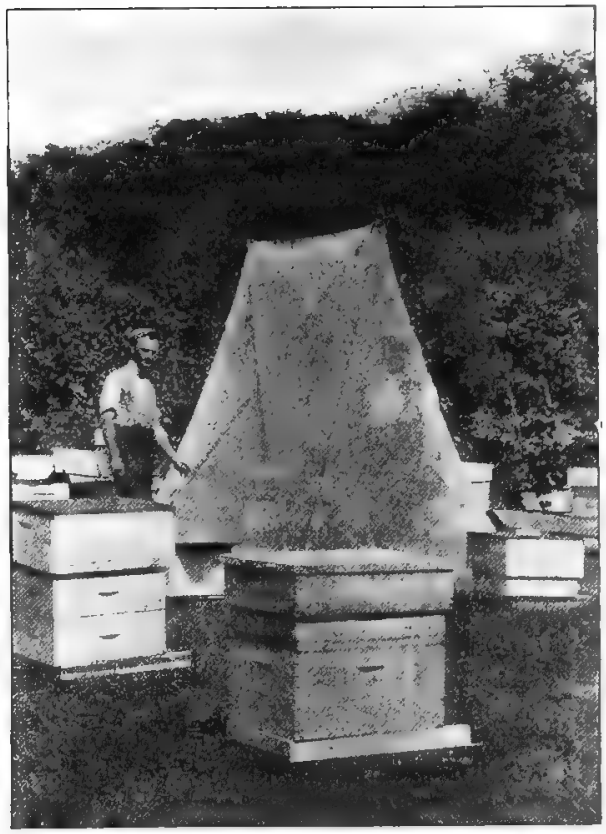

The bee tent.

It is very difficult to entirely stop robbing at once, if it has gotten 


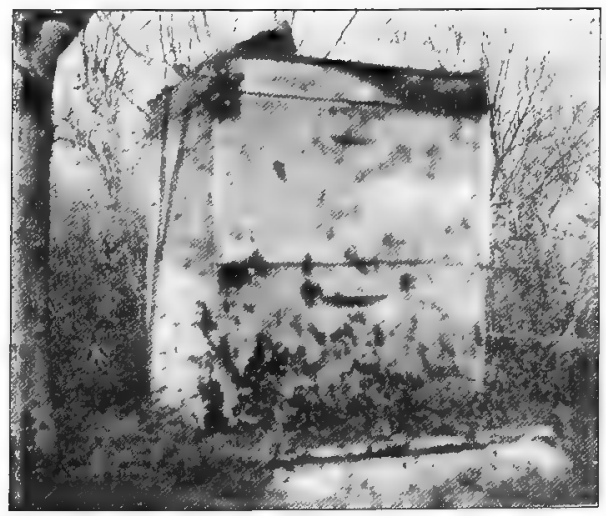

A serious attack.

fairly started. The first step that should be taken is to find the cause. When the bees have gained an entrance to stores in a building, it should be closed up immediately, and it is well to drive the bees away with smoke. If robbing is detected among the bees, the size of the entrance of every hive should be reduced till it is a very small one, so that the inmates may be better able to protect themselves. Ordinarily, a bunch of wet straw, or weeds, thrown over the entrance of a colony, in a bad case, will discourage attack, as the robbers do not like to enter any hive from which they can not escape easily, while the inmates of the hive willingly and readily pass through it. Sometimes the mischief is done by only one or two colonies in the apiary robbing out some of the weaker ones. In this ca:e, exchanging places, putting the hives of the robbers on the stand of those being robbed, and these on the robbers' stand, will confuse them to such an extent that the trouble will end. If a colony is almost robbed out when discovered, it is best to leave it to the robbers to clean up entirely, after which they will

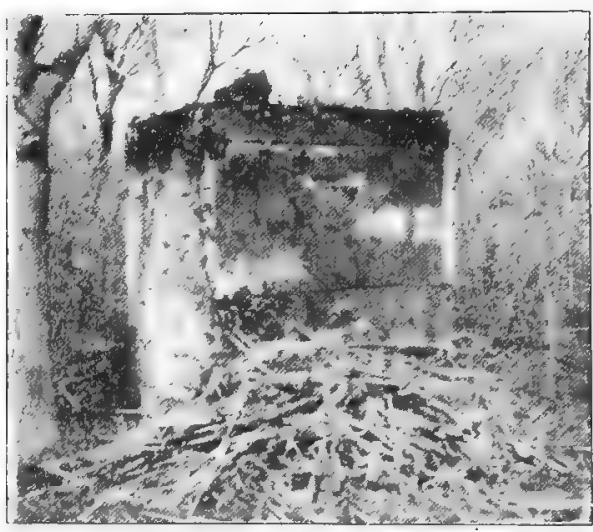

The robbing cured. quiet down, while if it is re-

moved there is danger of them pouncing on other colonies in their eagerness to get what was still left in the hive taken away. If, in a serious case, a colony attacked is not able to defend itself, it is best to take it into a dark, cool room, or cellar, until darkness puts a quietus on the robbing. When the colony is put back in its place in the apiary, the entrance to its hive should be contracted to just one bee space, so that only one bee can pass at a time; when they will be able to defend their hive properly. All operations should be done after nightfall whenever bees are very.much inclined to rob.

\section{HONEY PRODUCTION.}

The beekeeper must decide upon the kind of honey to be produced and equip the apiary with necessary fixtures for this. It is produced 
in two forms, comb honey and extracted honey, and the apiarist must be guided by the demand he may have for either one or. the other. Comb honey production requires closer looking to details, and more frequent attention to the bees, than the production of extracted honey, but it requires a smaller investment, and there is a good demand, at a better price, for it, while extracted honey has a more stable demand. Producing both forms in the same apiary is practiced by most beekeepers, and is a safe course to follow by the beginner, who can later make such changes as his experience and the demand will teach.

Comb honey can be more easily produced for home use than extracted honey, and, unless the beekeeper has more than just a few colonies to supply his own table, its production is advised. The investment with a few colonies for extracted honey production is greater, as it becomes necessary to procure a honey extractor and other appliances not needed for producing comb honey.

\section{WHAT IS HONEY?}

Honey is the nectar of flowers gathered by bees, transformed in some manner and stored in their combs by them. Sugar, or anything else fed to bees can never be changed to honey, as some persons suppose. Even if this were possible, it would not pay to feed sugar to bees in any manner, with the intention of "having the bees make it into honey," on account of the high price of sugar. Although the bees would store the sugar syrup in their combs, if fed to them, it is still only sugar syrup and it does not have the flavor nor the aroma of real honey. Besides this it would be contrary to the Pure Food Laws, as it would be adulterated honey, and, as this is easily detected, the violator would likely be justly punished. In order to comply with the requirements of the National Pure Food Laws, honey must come up to the following standard of purity for honey adopted

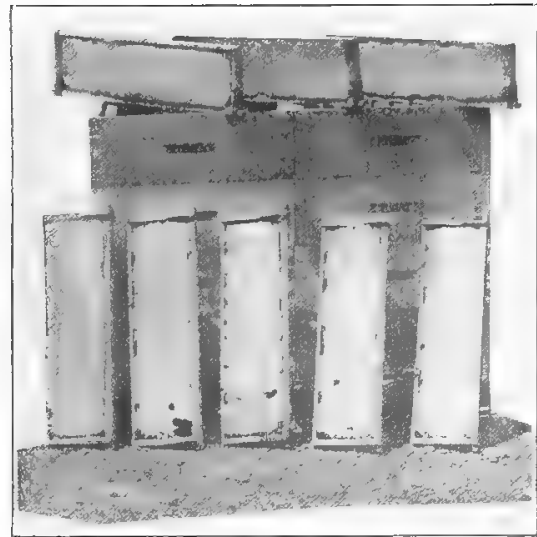

Just as built, by the bees.

by the Association of Official Agricultural Chemists of the United States:

HONEY,

1. Honey is the nectar and saccharine exudation of plants, gathered, modified, and stored in the combs by honey bees (Apis millifica and Apis dorsata); is laevorotary, contains not more than twenty five $(25 \%)$ per cent of water, not more than twenty-five hundredths $(0.25 \%)$ per cent of ash and not more than eight $(8 \%)$ per cent of sucrose. 
2. Comb honey is honey contained in the cells of comb.

3. Extracted honey is honey which has been siparated from the uncrushed comb by centrifugal force or gravity.

4. Strained honey is honey removed from the crushed comb by straining or other means.

\section{NO MANUFACTURED COMB HONEY.}

It has become necessary at various times to answer questions that have originated from the reading of sensational articles that have appeared from time to time, in various periodicals, to the effect that honey combs were manufactured, filled with very cheap syrup or glucose, and then sealed over with a hot iron and sold as comb honey. Nothing is further from the truth than these yarns. There need be no fear of the comb honey on the market being manufactured or adulterated.

There are two standing offers of $\$ 1000$ each, as forfeits, for a single pound of manufactured comb honey, that would deceive the buyer, but no person has ever been able to claim either of the forfeits, although one of these, made by a reputable firm, has been standing for more than fifteen years. The other forfeit was made by the National Beekeepers' Association, at its annual meeting in 1904. It certainly shows the impossibility of imitating the honey bees in their art of building their delicate honey comb. In addition to this, the well established fact that the beekeepers of this State, as a general rule, are reputed for honest production, should leave no fear on the part of the purchasers of their products as to the purity of the same.

This convincing proof is given for those who might have occasion to use it in answering like questions.

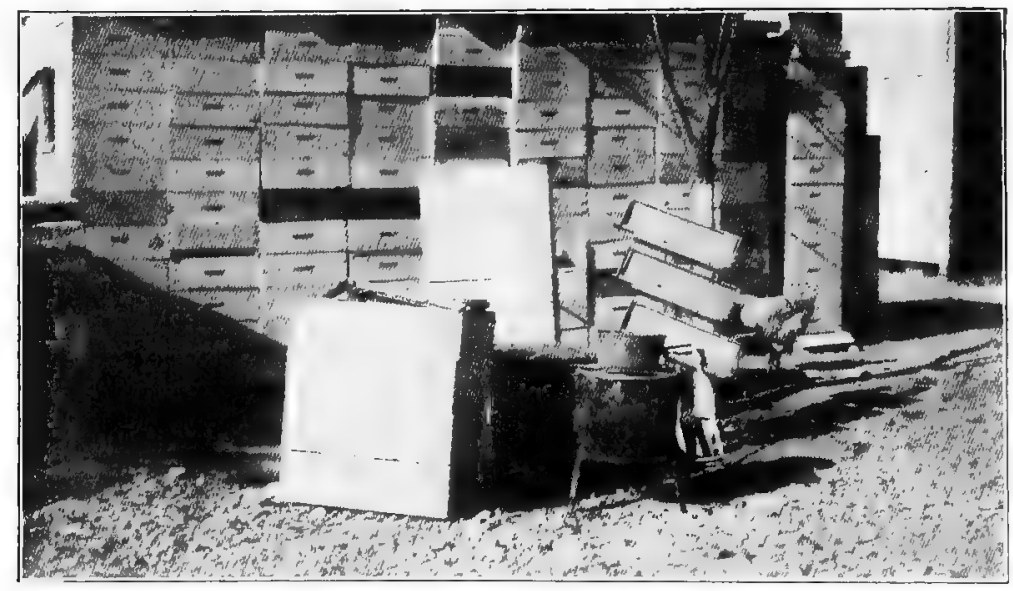

Supers ready for the honey harvest.

PREPARING THE SUPERS.

Before the time of the honey flow arrives, the beekeeper must get his top boxes, or supers, in readiness to be placed on the hives as soon 
as needed, when the bees begin to bring in the honey. This consists, after the supers have all been previously nailed up and painted, in putting into each frame what is generally called a "starter" of comb foundation. While some beekeepers use only a strip, one inch or so wide, and others use a sheet only half the depth of the frames, it is advisable, and more profitable, to fill the frames with full sheets of foundation at all times. The extra saving, in time and labor, in comb-building to the bees, especially when much honey is coming in with a rush, and the bees can not build combs fast enough to hold the honey, insures enough more surplus honey to pay several times over for the foundation used.

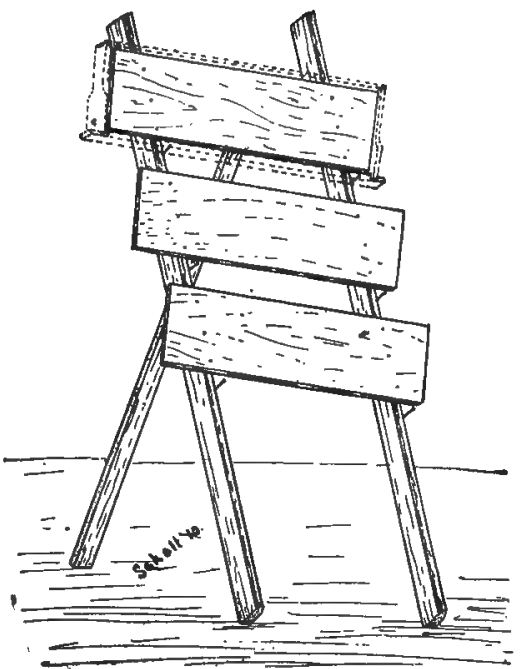

Frame rack.

One of the main secrets of securing larger crops of honey, and ultimate success, may be attributed to the judicious use of comb foundation at all times.

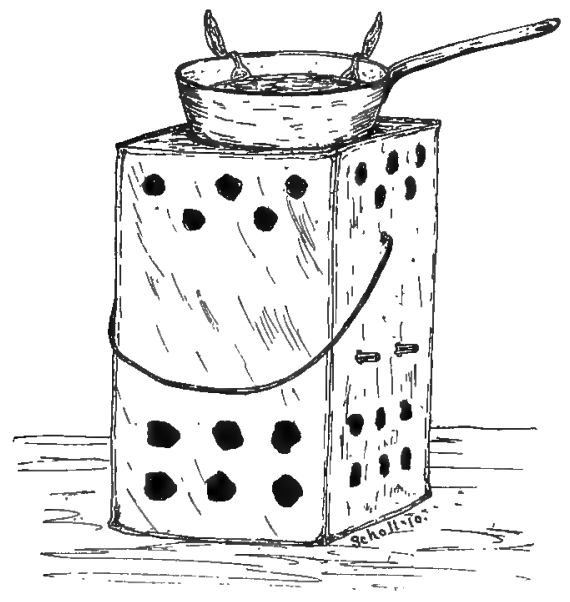

Fire pot.

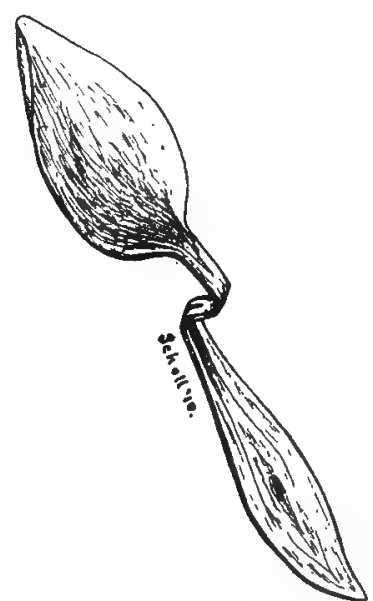

Wax spoon.

PUTTING 1N THE FOUNDATION.

There are various ways of fastening the foundation in the frames employed by different beekeepers. The most common method is that of fastening with melted beeswax. Usually a groove, for inserting the edge of the foundation, is provided. This is not necessary, however, and weakens the strength of the top bars of the frames. 
With a frame rack, provided with slanting boards, that space the foundation sheets in the exact place in the frames when these are placed on the rack, each sheet may be securely fastened with a spoonful of hot wax that is allowed to run along the foundation and the top bar.

An old five-gallon honey can, with part of its top removed, may serve as a fire pot, in which charcoals are preferably used. A common ten cent stew pot, and tin spoons, costing ten cents a dozen, of which the handles are bent so they will hang over the edge of the wax pot, may be carried with the frame rack from one apiary to another. Instead of the spoons, with their lip end beaten together slightly to direct the flow of the wax better, some beekeepers use what is known as a wax-tube, a hollow metal tube with a wooden handle, which fills with melted wax as it is inserted in the pot, and which flows out at the pointed lower end when the tube is guided along the foundation.

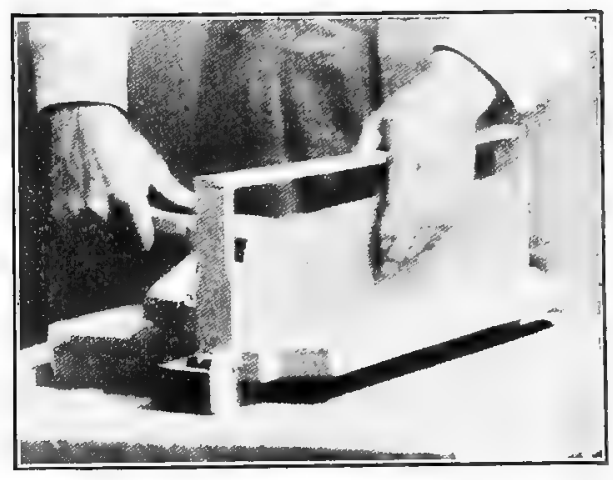

Wilder fastener.

Another way of fastening the foundation is by means of various presses used by some beekeepers, in which the edge of the foundation is fastened to the top bar of the frames by pressure. This method is not very popular. Besides, it is necessary to use about $3 / 3$ of an inch of the width of the sheet of foundation used for each frame to fasten it with, which is practically that much loss of foundation, which is more expensive than melted beeswax, as scraps, or off grades, of wax are generally employed for the latter.

After the frames are filled with foundation, the supers containing them are stacked up near the apiary where needed, on flat platforms, and each stack covered at the top so that bees, or mice, can not gain an entrance. Otherwise, the foundation may be destroyed in a wholesale way, especially by the bees during a dearth of honey, as they will tear down the foundation and carry home the wax.

\section{WHEN TO PUT ON SUPERS.}

The beekeeper should devote much time to the study of his locality, the source of the honey flows, and when these are to be expected. This must be known, so that the supers may be put on the hive at the proper time. To put them on long before they are needed, gives too much room for the best welfare of the colonies; besides, the bees destroy the foundation in them by gnawing it down. But, to leave the supers off until they are actually needed, often results in the colonies becoming crowded and this tends to bring on the desire to swarm.

According to the old rule, the proper time to give supers was when the bees were adding bits of white wax to the upper part of the 
comb along the top bars, but this is too late, unless swarms are desired, as this indicates a crowded condition in the brood chamber. It is better to put them on a little before the real honey flow begins, than even a day later, as this might mean a serious loss in honey, both from the lack of needed room at the right time, or by inducing swarming at the expense of honey gathering.

\section{WHY BEES DON'T WORK IN SUPERS?}

This is another question that is often asked. The inexperienced beekeeper expects that at a certain time all colonies, no matter what the circumstances or conditions may be, will begin to store honey in the supers. A colony may be so weak in numbers that it has all it can do to take care of the necessary work in the brood chamber; hence, can not go into the supers to work, or a colony may be strong enough, but there may be room in the brood chamber that will be filled before storing elsewhere, as the tees prefer to work as near the brood nest as possible. Many colonies, however, hesitate to enter the supers, even during the honey flow, and with the brood chamber filled full, and it then becomes necessary to entice them into the supers by giving them partly built combs of honey in these. After they have once begun work in them, other conditions being favorable, they will continue to do so as long as the honey flow lasts.

The most practical way of getting such colonies started in the super work is to exchange their super for one from a colony that has already begun work nicely. It is not necessary to free these supers entirely of bees, but it must be certain that the queens are not in them when taken to another colony.. It is quite safe, however, to drive most of the bees out of the supers with smoke when the covers are lifted off, and the queens will leave the supers in seeking refuge in the brood chambers below. Then the supers, combs, bees and all are simply exchanged and set on the colonies that refused to work in them before. The bees brought with the supers, in which the bees were already at work, will be an additional aid in continuing the work in them.

Often the reason why the bees do not enter the supers is because there is no honey for the bees to store, even if there is an abundance of bloom, as there may not be any nectar in it.

\section{COMB BUILDING AND BEESWAX.}

The combs are built by the bees out of pure wax, and for two purposes, to rear their young, and for storing their food-honey and pollen. The wax is secreted by the bees from certain glands that lead to the scale-like rings, or "wax pockets," on the lower side of the abdomen, and is not brought from the flowers in little round pellets on the hind legs of the bees, as many suppose. This is pollen and not wax.

When the bees are secreting wax they hang together in festoonlike fashion, and, consuming much honey, undergo a certain sweating. process, during which the liquid wax passes through the glands and 
forms into little scales as it comes in contact with the air in the wax pockets. These are removed by the bees' legs, and moulded into shape where comb is being built. In this way thousands of these little scales are formed and added where needed. Requiring the consumption of much honey and time to produce a pound of wax, it is an expensive product and this is why honey with the comb costs more than that which has been extracted from the comb.

In the center of the perpendicular combs, as they hang in the hive, is a "septum" or "mid rib," from which the walls of the sixsided cells extend. The smaller sized cells in the comb are the worker cells, and occupy the largest part of the main comb surface, while the larger drone cells are generally situated nearer the lower edges. The worker cells measure five to the linear inch. There are nearly 29 worker cells to the square inch on each side of the comb, making almost 58 cells to the square inch of comb. There are four drone cells to the linear inch; about 18 to the square inch on one side and 36 cells to the square inch of comb. The two sizes are easily distinguished.

As few drone cells as possible should be allowed, as the more drone reared by a colony the more valueless consumers there are to use up surplus honey. Enough of them will be reared to fertilize the queens in spite of this precaution. To suppress them, as much as possible of the drone comb should be cut out and replaced with worker comb, which can be easily patched in. The use of full sheets of comb foundation at all times and under all conditions, will prevent the bees from building drone cells.

Newly built combs are pure white, but become darker with age, from the continuous travel over them by the bees and the constant addition of discolored bits of wax mixed with propolis and other foreign matter. When brood is reared in them, the accumulation of cocoons left by each hatching bee hastens the darkening of the combs, and very old brood combs finally become almost black in color.

Although there is a difference of opinion as to how many years such combs may be used satisfactorily for brood rearing, on account of the constant accumulation of the cocoons, causing the septum, or mid rib, of the combs to become thicker, thus lessening the length of the cells to a certain extent, it is well that they should not be used for brood rearing too long.

\section{RENDERING BEESWAX.}

Beeswax is rendered by melting the combs and bits of wax that accumulate. It is a valuable by-product of the apiary, and there is always a good market for it at 20 to 30 cents a pound, according to quality. Every bit of comb and serapings from the hives and frames should be carefully saved, as the wax from these pays well for the trouble. The wax in the general market is of all shapes and sizes of cakes and is of any color, from white, yellow, brown, and sometimes black, depending on the method employed and the amount of bleaching received during its rendering, or the amount of foreign matter and dirt incorporated with it. 
Rendering wax in a small way does not require a complicated equipment. The combs, after being placed in a gunny sack, which is securely tied, are suspended in an ordinary wash boiler filled about two-thirds full of water. This is placed on a hot stove to boil. While it is boiling, the sack of combs is agitated and occasionally pressed, with considerable force, to the bottom and sides of the boiler by means of a stout board paddle, so that the pressure will force the melting wax out of the sack. The melted wax will rise to the top, and, when all possible is worked out, the boiler is set aside, several bricks put in to hold the sack down, and a solid cake of wax will form as it cools. It is well to see that the wax does not boil over, or that none is spilled on the stove, as dangerous results from fire may follow.

Old and dark combs should be put into a tub filled with soft rain water about twenty-four hours before melting, weighting them down with heavy objects of some sort. The impurities in the combs will be loosened by the water.soaking the cocoons left in the cells by the young bees, and will prevent these from absorbing wax during melting, which amounts to a great deal. After draining them, these may be melted in the usual way.

\section{SUN EXTRACTORS AND PRESSES.}

Another method is the use of the sun wax-extractor, with which the heat of the sun is utilized to melt the combs. Such a solar extractor is one of the handiest and most valuable appliances in any apiary and, as they are inexpensive, considering the work they perform, and are easy to construct, every beekeeper should have one. Placed in the apiary, it is ready at all times, and every bit of comb can be immediately thrown into it, thus leaving no excuse for allowing the smallest bit of wax to go to waste. Its real value will be bound to be appreciated in our warm southern climate, where the wax moth larvae are a serious pest, in that the solar extractor will take prompt care of combs which would otherwise be destroyed by these moths if allowed to accumulate.

A strong box of suitable size may be supplied with a removable glass cover over its entire top. A false, good and solid bottom, three-fourths the inside length of the box, on which the comb is to be placed, is nailed about half way from the true bottom. A strip of coarse wire cloth tacked on near its lower edge

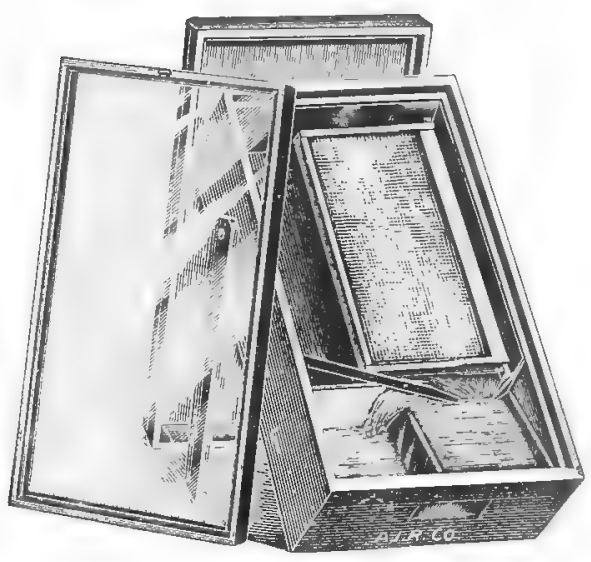

Solar-wax extractor. serves as a strainer, as the melted wax runs down into a vessel of some kind placed in the lower part of the box. The extractor is placed in a slanting position and with the glass facing to the south 
so that the sun shining through it will melt the comb, which will then run into the vessel provided for it. This vessel, preferably a tin pan several inches deep, and with outward sloping sides, should be partly filled with water when the extractor is in use, to facilitate the removal of the cake of wax, which would otherwise stick to the vessel.

As not all the wax is removed by the solar extractors, the refuse, or "slum gum" remaining, should be saved and later subjected to hot water extraction under pressure in the wash boiler, as already described.

Wax presses are used by more extensive beekeepers, and it is only by this means that most or nearly all of the wax can be obtained, es. pecially from old, tough brood combs. These extractors are of two, kinds, viz.: one in which the wax is boiled in separate boilers and

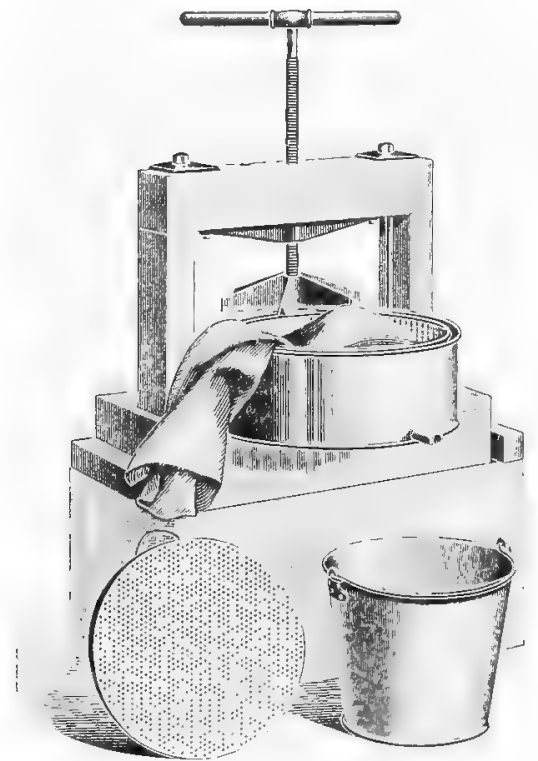

Root hatch wax press. then dipped from these into the press; the other, in which the press and boiler are in one, and the pressure is supplied to the combs while these are boiling. Directions for operating accompany each extractor.

Wax should never be rendered in iron resceptacles, as this has a tendency to make it dark colored. Sometimes sulphuric acid is used to clarify beeswax, but this is not advised, as the wax may be easily spoiled by the use of too much acid. When beeswax is to be shipped it should not be wrapped in paper, a mistake made by many, but the cakes should simply be placed in clean double sacks, one placed within the other, and the openings sewed up just as grain sacks are sewed. The shipper should be sure to put his own name and address on the packages as well as that of the consignee, so they may be identified and trouble, such as frequently occurs, be prevented.

\section{COMB FOUNDATION.}

Without comb foundation, the frame hives would be worth little more than box hives, and to get the bees to build straight combs in the frames, comb foundation was invented. When the hives with their frames are to be used, each frame should be filled with a full sheet of comb foundation, which is a thin sheet of wax, having the impressions of the bottom of the cells of the honey comb on it. From this the bees build, or "draw out," the cell walls and thus complete the combs. It is exactly like the septum or mid rib of the natural comb, and is made out of sheets of pure beeswax, which are passed through 
a comb foundation mill, resembling very much a clothes wringer with metal rollers. These rollers are engraved on their surfaces in such a way that the impressions of the cells will be left on the wax sheets.

Comb foundation may always be profitably used, as it insures the building of straight combs in the frames, even if only a very narrow starter is used. A serious objection to using only starters is that it allows the bees
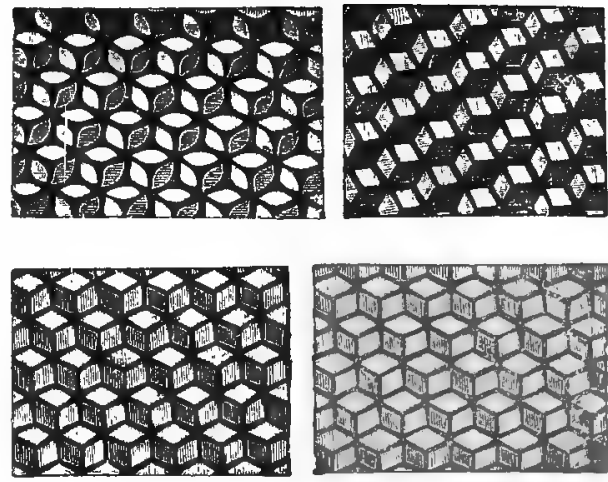

samples of ditferent grades of foundation.

to build too much drone comb under most conditions. Full sheets

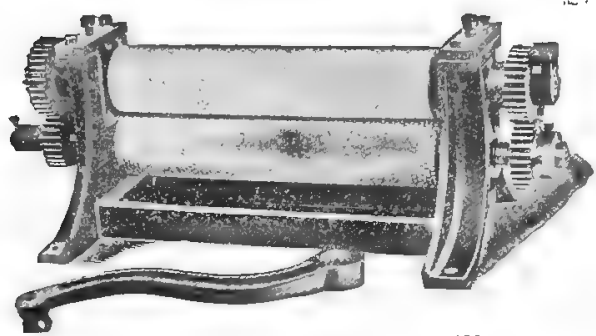

Comb foundation mill. used at all times will insure not only the straightest combs, but will force the bees to build all worker cells.

Foundation is made in several weigthts and sizes to fit the particular frames in use. Medium and light brood foundations are used in deeper frames, especially in brood frames, the light brood always with wires stretched in tho frames. The wires are imbedded in the foundation with a spur wire imbedder, because the weight of the bees upon it would otherwise tear the sheets down. Thin and extra thin super foundation is intended for the supers with shallow frames, or in the section boxes. The thin foundation is more expensive, because there are more sheets to the

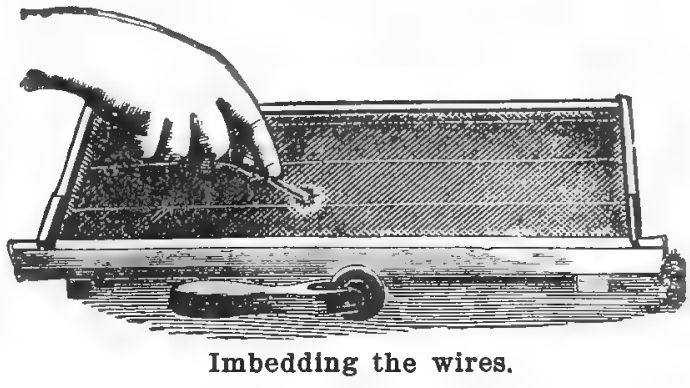
pound, and it requires more labor in making than the heavy grades.

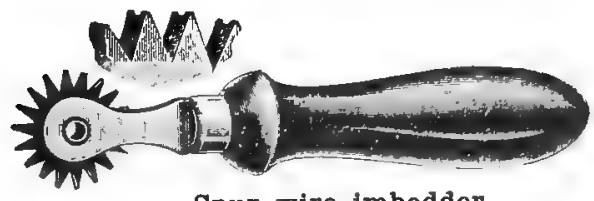

Spur wire imbedder.
Although some beekeepers make their own foundation on a hand mill, these are very few compared with those who buy their supply from large manufacturers, who make this a specialty and are, conse-

quently, better prepared to furnish a superior grade of foundation. 
Although the price of foundation seems high to the average beginner, and the use of it, especially in full sheets, appears expensive, he should not hesitate to use it at all times, as it pays to do so. All experienced beekeepers are so well aware of this fact that they use large quantities of foundation annually.

\section{WHY COMB HONEY COSTS MORE.}

Those who are acquainted only with the old method of procuring "strained" honey can hardly understand why comb honey should be higher in price, since it requires much work and fussing to separate the honey from the wax and hence they opine comb honey should be the cheaper of the two. Under that method, the combs, often containing large quantities of pollen, and sometimes even young brood, are cut from the box-hives, then mashed up and placed in coarse cloths so the honey can be pressed out, resulting in a product more or less tainted in flavor and color. When it is practiced, it is no wonder that they can not perceive why comb honey should sell for more.

The extracted.honey, however, is produced very differently. With extracted honey production the combs, once built, are used over and over again, the honey being removed from them by means of the honey extractor, and the combs returned to the hives to be filled again, thus saving all the time and honey that would have been consumed by the bees in comb building, and the human labor necessary with "strained honey," and securing the purest and clearest, fine flavored honey, free from impurities. In other words, extracted honey is thrown from the combs exactly as the bees stored and ripened it in them. Thus, very large quantities of extracted honey can be produced much cheaper than comb honey.

With comb honey production these large yields can not be obtained, for the main reason that the bees are required to build new combs in which to store honey. This delays the work materially, besides making it necessary for the bees to consume from twelve to twenty-four pounds of honey, out of which the wax is secreted, for every pound of comb built.

\section{ARTIFICIAL COMB.}

Some people have the erroneous idea that artificial honey comb is manufactured ready for the bees to fill with honey. A few years ago at a cost of thousands of dollars, experiments were conducted in making comb foundation with extra deep cells, but were abandoned as futile. - Not only was the matter of manufacture a difficult one, but the use of the foundation with the deep cells was objectionable for several reasons, chief among which were its toughness, due to the heavy milling of the wax, which would have been disagreeable in the finished comb honey; the extra trouble in packing for shipping, and the high price of such foundation.

The farthest step that has been taken in the direction of aiding bees in comb building is the manufacture of comb foundation with a very thin base and rather thick lines of was which mark the begin- 
ning of the cell walls. In thinning these when building the combs, the bees utilize the extra wax in lengthening out the cells. Such foundation can not, properly, be called artificial comb.

\section{WORK SHOP AND HONEY HOUSE.}

Every beekeeper needs to have a place where bee work may be done in a satisfactory manner. The beginner may manage to get along temporarily by converting a room of the residence, the attic, or a place in the barn or other out-building, into a work shop in which to nail up and store hives and dozens of other things, and in which to extract and pack the honey crop. Such an arrangement might do for a year or two, but it is more convenient and cheaper in the end, to construct, as soon as possible, a building for these purposes, be

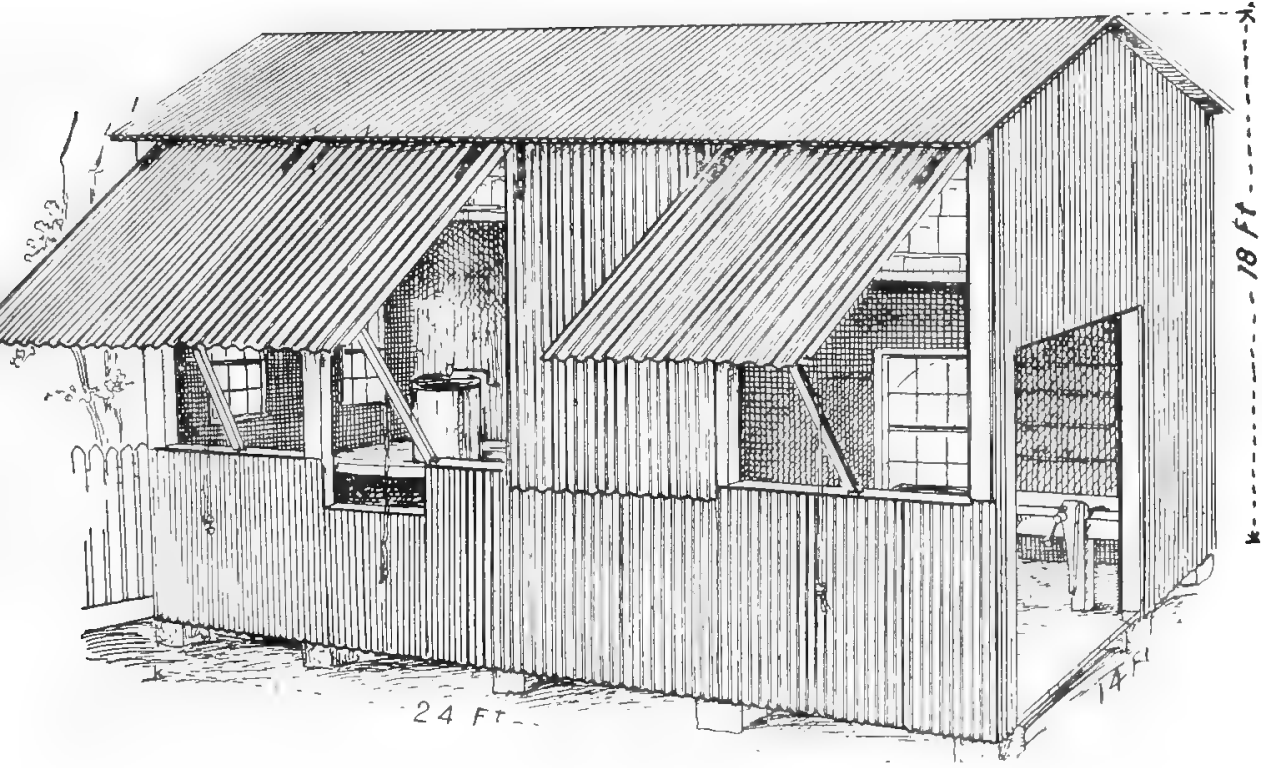

The author's corrugated fire proof honey house and work shop.

it only a small one to begin with. It is the next necessary essential, after the bees and supplies have been secured Too many beekeepers are making the mistake of trying to do their work in places entirely unfit for the purpose. A well arranged, commodious building permits a greater amount of, and better, work to be done, and, at the same time, much more agreeably.

\section{UNDER ONE ROOF, BUT SEPARATE.}

A building so constructed that one part can be used for a work shop, while the other is screened off to be used solely for a honey room, is preferable, for the reason that, unavoidably, there is more or less dust and trash in a work shop, and a honey room should be as tidy and clean as it is possible to make it. 
Such buildings may be variously constructed. One that will answer the purpose most satisfactorily is illustrated herewith. It is covered entirely with galvanized, corrugated sheet iron, over a frame work made of cheap lumber, making it low in cost of construction and very durable.

The cross-section view is self-explanatory. It shows the arrangement of the various floors, there being four of these, each used for a different purpose. The honey room floor is elevated, so that all heavy loading of honey to and from wagons is done without any high lifting, through a side door. This is a great convenience, especially where much honey is handled. The space underneath this floor is open into the work shop and is used for storing many things desired

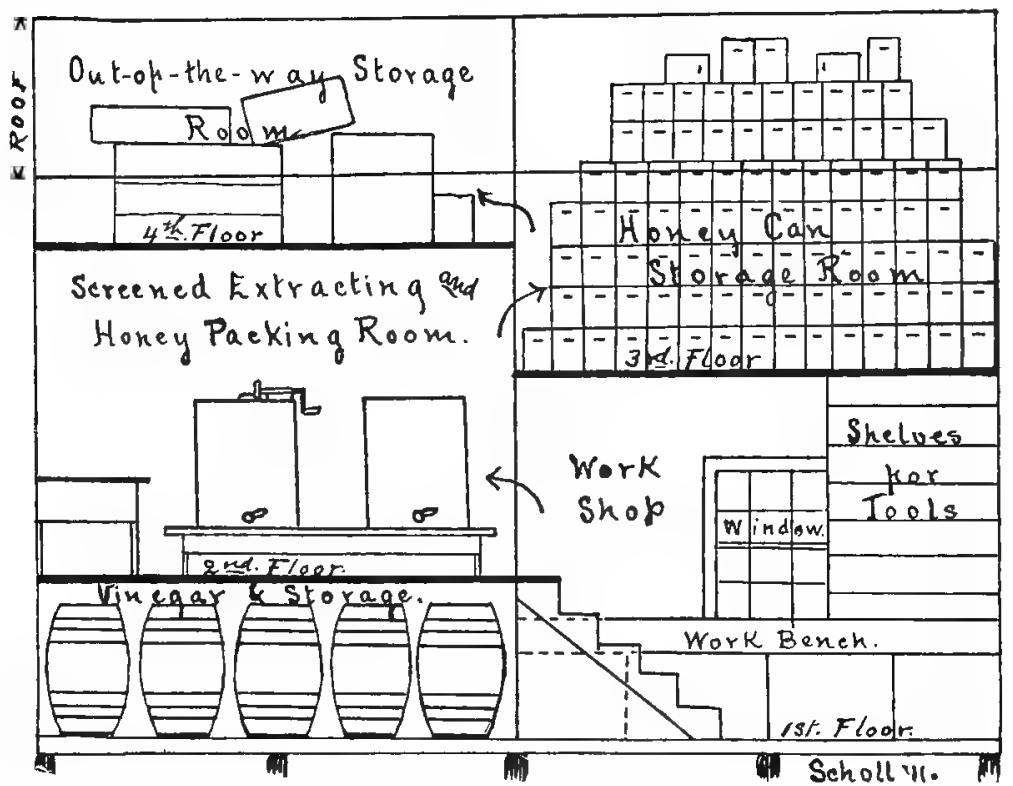

Cross section of honey house.

to have in easy reach, besides affording an excellent place for honey vinegar making. The upper floors are used as indicated, the honey cans being in immediate reach when needed for packing the honey, and the highest floor being stored with things seldom needed.

To give ventilation and thus keep the house cool in summer, as well as to supply much light in the work rooms, the entire walls toward the south are arranged in shutter fashion, so they may be easily opened by simply pulling a small rope. Extending out from the building, these provide shade, in addition to ventilation, making the building a cool one in hot weather, while giving protection when the weather is bad. These shutters are hinged with folding extension arms by which they are easily opened or closed. 


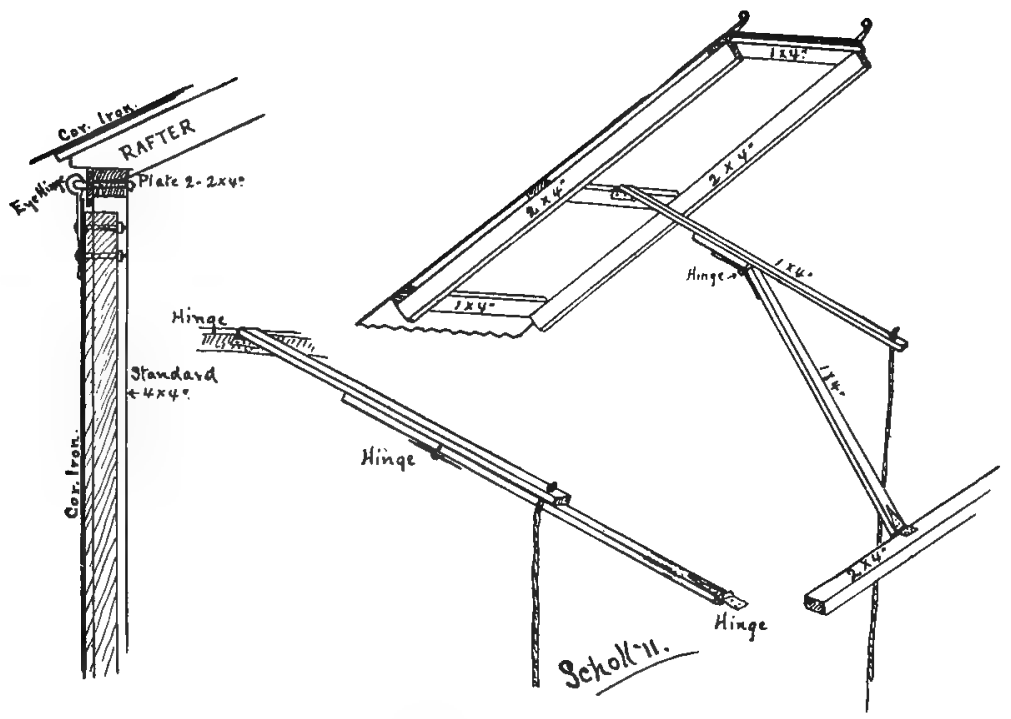

Showing details of shutters.

EVERYTHING IN ITS PLACE.

One of the main objects should be to have a place for everything and everything in its place, so that necessary tools and appliances may be found without having to hunt all over the premises for them when they are needed. Good tools mean half of the work done to start with, and all work done better than with bad tools. Suitable shelves and tool boxes should be arranged in the shop and in the honey house.

For nails of various sizes, of which every beekeeper should have a supply, since they are always needed, nothing answers better than small boxes that can be hung against the shop wall. They can easily be made and the size of the nails be indicated on the front of them. There are dozens of other things just as convenient

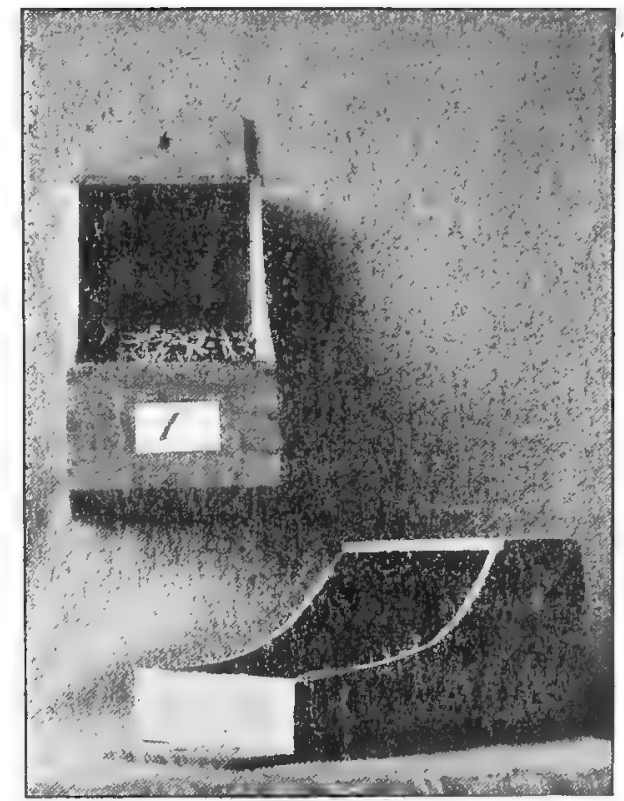

Nail boxes. that can be easily made by the beekeeper during spare moments, 
that will help make work during the busy season much more agreeable and easier to do.

\section{WHERE TO KEEP HONEY.}

One of the most serious and most common mistakes is to store honey in the cellar or in a cool, often damp, room, or in the case of consumers, with only a small quantity, to keep it in a refrigerator. This mistake is made by many inexperienced beekeepers, as well as others, and is the reason why attention is called to the matter here.

Honey readily absorbs moisture if kept in a cool, damp place, and, besides consequently losing in quality and flavor, it may sour and ferment if not properly cared for, thus spoiling it entirely. Honey should always be kept in a warm, dry place, during all seasons, because it thereby keeps from absorbing moisture and remains liquid much longer.

For small quantities no place is better than the kitchen cupboard, or a place behind the stove. The warm temperature does not only keep the honey well, but it improves in density and flavor, as it becomes very thick and heavy in body. It is a good plan to inform consumers of honey of these simple facts. Beekeepers will gain by giving such information to their customers. The beekeeper himself should strive, of course, to keep his own honey, if he has any large amount of it, in a convenient dry place in his honey house, or otherwise, so that moisture may not affect it. Honey that has absorbed a great deal of moisture and is very thin, can be heated slowly, to evaporate the surplus water, by setting the vessel containing it on some thin boards to prevent scorching, inside a larger one filled with water. Honey that has become sour can not be restored and is only fit for making vinegar.

\section{HONEY AS A FOOD.}

Comparatively few people know the true value of honey as a food, and to what extent it is used for medicinal purposes. Honey was much more generally employed in olden times, before sugar came into use. It was probably the only sweet then. It is mentioned many timès in sacred and early profane history. The honey of today is nature's purest sweet. It is much more wholesome than cane sugar, since it does not need to be changed by the digestive process, like sugar, before it can be assimilated, nor tax the kidneys like sugar does; hence it has a tendency to prevent such ailments as diabetes and Bright's disease. It is already inverted by the bees. Especial care should be paid to children for they crave sweets, and too much cane sugar, or candies and other things containing it will have a tendency to overtax their kidneys from an early age. Satisfying this longing by the use of the more healthful, natural and already prepared sweet, honey, is indeed a wise part of the parent's duty, and the desire for other sweets will be abated, to quite an extent.

As a natural food, honey, while the price may seem high at first thought, goes farther and contains more nutritive qualities than other sweets. A tumbler of honey will spread more slices of bread than 
the same amount of preserves, jellies, or the many syrups on the market, most of which are adulterated and hardly fit for consumption. Yet these are used the country over instead of good honey. It is to be hoped that the time is not far removed when the true value of honey as a healthful, nutritious food, will be better understood.

- For baking, especially by commercial bakeries and the large biscuit factories, immense quantities of honey sre used, and cakes and eookies, in which it is employed, are not only more delicious, but keep soft and fresh longer, instead of drying out and becoming stale like those baked only with sugar. In confectioneries honey is used extensively, also in numerous ways in cooking, and in various summer drinks. Many persons use it entirely in place of sugar in drinks of hot water, coffee and tea. It is well, however, to be careful about substituting honey wholly for suyar, as this can not be done satisfactorily in all cases. By carefully trying the addition of a little at a time, the right proportion may be easily ascertained, and honey used to advantage, especially as regards health.

From the beekeeper's standpoint, it is a good idea to preach these truths at all times, especially through the home newspapers, thereby not only doing a great work for the health of his fellowmen but also advertising his products. Presenting the editor of a newspaper with a nice sample of honey, and furnishing him with the facts of its healthfulness and usefulness as a food, preferably in a written article on the subject, so he can print it as news, is of a mutual benefit to both. It will mean a greater demand for honey of the beekeeper, and his advertisement in the paper, so it may be known where such good honey may be obtained, profits the editor. To increase the demand is to create a better price for the product, and is to be encouraged.

\section{HONEY VINEGAR.}

The most healthful vinegar can be made from honey, and many beekeepers make this, not only for their own household use, but to sell as well. It has not been found profitable to make honey vinegar on an extensive scale, on account of the many cheap grades of vinegar on the market, some of which ought not to be used at all, but with which the better honey vinegar must necessarily come into competition. It is for this reason that it is not manufactured to any extent. Every beekeeper ought to save all waste honey that otherwise would be lost in the washings, and turn it into vinegar. With a little advertising it is possible to sell, quite easily, several barrels of this vinegar every year.

Poor grades of honey, the washings from the cappings and combs, when these are washed, drained and dried preparatory to melting into wax, and all rinsings from honey cans and utensils, may be used for making honey vinegar. It is understood that only clean honey washings are to be used, soft rain water being preferable for this purpose. To test the solution for the proper sweetness, a fresh egg must float therein so that only a small part of it, the size of a silver dime, will be exposed, or a hydrometer may be used to make the test. A pound and a half of honey to a barrel of rain water is about the right proportion. To destroy all undesirable germs that 
may interfere with proper fermentation of the liquid, or the honey used, it is previously heated to the temperature of 180 degrees Fahrenheit, the proper precaution being taken not to scorch it.

The sweetened water is placed in barrels, filling them about threefourths full and covering the bungs with a double thickness of cheese cloth. The barrels are kept in a dry warm place, not below 70 degrees, to undergo the first, or alcoholic fermentation. When this is completed, and all the saccharine matter is used up, the acetic fermentation begins which turns the liquid sour. This can easily be detected by smell, and, if it has not begun within ten days, a small quantity of good vinegar should be added, or if it can be obtained, some clean "vinegar-mother" from an emptied vinegar barrel at a grocery store, would be better. From now on, all that is necessary is plenty of air, and a sufficient amount of warmth. The barrels should not be placed outside, unprotected from the sun and weather, as many beekeepers do.

To hasten the process of vinegar making, after the acetic stage is reached the barrels may be so arranged on an elevated scaffold that the vinegar may be allowed to drip from them into, and slowly pass down through, a trough filled with oak shavings, into another barrel at its lower end. This must be repeated several times and in a warm atmosphere. The acetic acid bacteria multiply very rapidly on the shavings after the vinegar has passed through them, and if the work is properly done, good vinegar can be obtained within three to four weeks. After it is well matured it should be transferred, by drawing it off carefully, from one barrel into another several times, for this assures a much elearer product. When finished it should be bunged up.

\section{COMPARATIVE PROFIT IN COMB AND EXTRACTED HONEY.}

Since the market demands both comb and extracted honey, both forms are produced. It is rather difficult to say just what the relative net profits would be in each case. Granting that an average yield of extracted honey is 100 pounds, at 8 cents per pound we would have the sum of $\$ 8$. In this case, after the extracting combs are once constructed by the bees, they are used over and over again. This saves the bees much labor and makes its production easier for the beekeeper, besides reducing swarming to a minimum. Another advantage is, that extracted honey can be kept over from one season to another in case of low prices or other reasons, if desired, without danger of deterioration. If it does granulate during cool weather, it can be reliquified quite easily, and then sold as readily as if it had always been fluid. This can not be done with comb honey, as the combs would be spoiled by heating.

Figuring that, under the same conditions, the average for comb honey, in one pound section boxes, would be 50 pounds per colony, and that it would sell for 16 cents per pound, we would also have $\$ 8$. However, the cost of preparing the comb honey supers every year with new sections and foundation, and the extra labor of getting these ready, and further labor and expense of putting the comb honey in expensive shipping cases, and crating these before the honey can be marketed, increases the expense and lessens the profits of section 
honey production over the extracted honey. Besides, the bees do not like to build in the small compartments of the section supers, and hesitate to enter them readily. This causes further delay, loss of time and honey, and, as this condition results in the bees becoming more or less crowded in the main part of the hive, which is conducive to incite the swarming fever, the bees swarm instead of gathering honey when the main flow comes. The result is, a great deal more work for the apiarist, and a smaller average of honey per colony, ranging from 25 to 75 pounds of section honey per colony.

Bulk comb honey is sold for the average price of 11 to 12 cents per pound after it is packed for the market. It must be considered that one-third of the honey, in the package, is extracted honey that is poured over the comb honey after the cans have been packed full of this, to fill up the open spaces and make up the required weight. A sixty-pound can of comb honey at 11 cents per pound will be $\$ 6.60$. Since 20 pounds of the contents are extracted honey at 8 cents per pound, this must be deducted from the $\$ 6.60$, leaving $\$ 5$ for the 40 pounds of comb honey in the can, and we find that the beekeeper receives 12 1-2 cents per pound for the comb honey. The arerage returns per colony, for bulk comb honey under the same condition, is practically the same as for the other two kinds, but the great demand for this kind, and its ease of production, makes it more profitable and, consequently, it is very extensively produced. Due to this demand, bulk comb honey has always been sold long before the winter months, and the fear of deterioration by granulation has been avoided.

While the total price received in each case is the same, the production in one is easier and cheaper, and hence the profits greater. While the figures used above to compute yields per colony may not be exactly correct for all localities, they are very nearly an average for the main honey producing sections of Texas, and, whetherthey are lower or higher, the comparison would remain practically the same. The prices quoted are those ranging on the average market here at the present time.

\section{TEXAS STANDARD PACKAGES.}

Texas has its own standard size packages for honey, for both bulk comb and extracted. These are all figured on a basis of 120 pounds, or 60 pounds, per case. For extracted honey, the regular 60 -pound square can, two to a case, prevails, but friction top pails and cans, formerly adopted for bulk comb honey, are also extensively used. For bulk comb honey the same size of square cans, two to a case, have large eight-inch screw caps to admit placing the comb honey in them. Twelve-pound friction top pails, ten in a case,

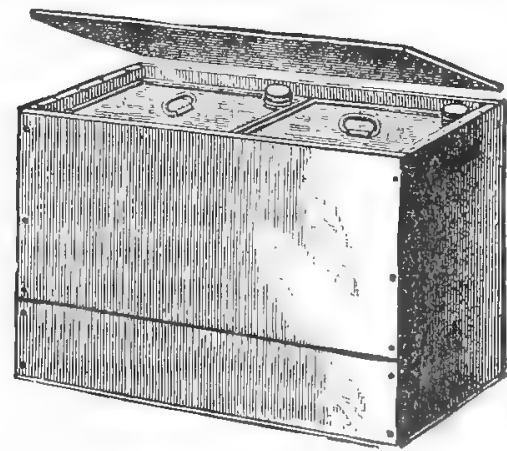

Sixty pound honey cans. 
making 120 pounds; six-pound friction top pails, ten in a case, making 60 pounds, and three-pound friction top cans, 20 in a case, also making 60 pounds, are used for both comb and extracted honey in smaller sized packages for retailing in the original package. This
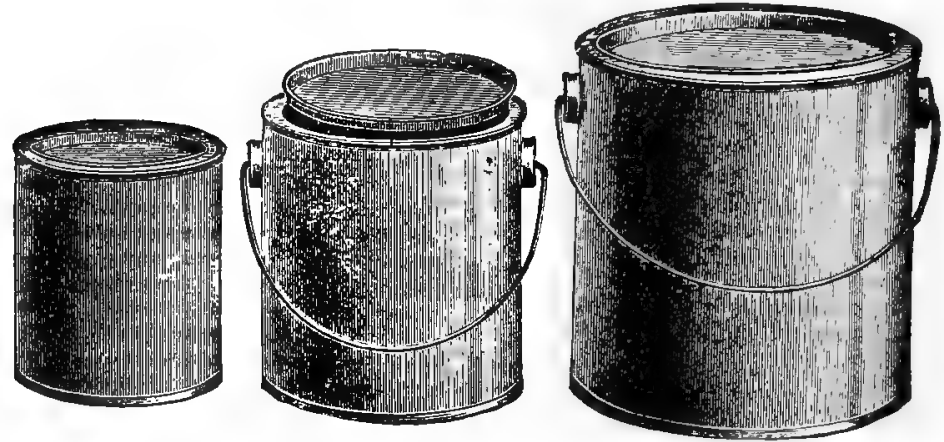

Friction top honey pails.

standard is so well known that orders are always made in accordance with the price lists, in all of which the various sizes appear in the same regular order.

Barrels are not advised for honey, as they are very cumbersome in handling, besides there is danger of losing the honey by leakage due to bursting of the hoops or the drying out of the staves in our southern climate. They are good enough for the inferior grades of honey, and are used extensively for shipping them to large biscuit and cracker factories; but, while this is the case in the eastern part of Texas and in adjoining States, honey cans are almost entirely used in the West; and, for good grades of honey, such are an advertisement for the producer, and their general use is therefore recommended.

The question regarding the advisability of using second hand cans, those that have been used once before for shipping honey, is one that confronts many beekeepers, on account of the cheap price at which they are advertised. Good honey should never be risked in anything but bright new cans, and, even for poorer grades of honey the results of the risk may prove them dear at any price.

\section{BULK COMB HONEY.}

Since the expense of section honey production is so much greater, the Texas beekeepers long ago resorted to other ways of producing comb honey, and today there is very little section honey produced in this State. Bulk comb honey is the leading product of 'Texas apiaries, and, produced in shallow frames, with full sheets of foundation, the bees do not hesitate to enter the supers, therefore making it possible to obtain larger averages per colony. Although the bees are required to build their own comb, it is not necessary to crowd them, and, consequently there is less swarming. In this case they work much more readily in the supers and the colonies are more easily managed. On the whole, bulk comb honey production is easier, less laborious and 
less expensive than section honey, and not much more difficult to produce than extracted honey, while the profits are much greater.

The average yield per colony of bulk comb honey, comb and extracted honey together, is about 100 pounds, and, as extracted honey is required to put up with the comb honey, both are generally produced on the same hive. The extracted honey supers are placed on early in the season to catch the early honey before the season is well enough advanced for the best work in the comb honey supers, and they are also made use of again at the end of the flow to catch the honey which otherwise would result in a great deal of unfinished comb honey. Thus the comb honey is produeed rapidly during the most favorable part of the season, or the honey flow, and during a time when the bees are secreting wax more rapidly, which lessens the delay in comb building and consumption of honey otherwise necessary. Using the extracted supers in the early spring furnishes the bees extra room and keeps them contented longer, so that when still more room is provided by giving the shallow supers with frames, containing full sheets of foundation when the flow begins, there is no desire to swarm.

Instead of using the regular deep hives or those of the Langstroth dimensions, for supers, as well as for the brood chamber below, shallow supers $55 / 8$ inches deep, are used more extensively now, for they are more suitable in size for the manipulations outlined. It is possible to use a much lighter weight of foundation in shallow frames. which is quite a saving and makes the presence of such less noticeable in the finished product than is the case where heavier foundation is used.

For extracted honey shallow frames are also well adapted, because their comb surfaces are more easily uncapped before extracting, as the knife reaches

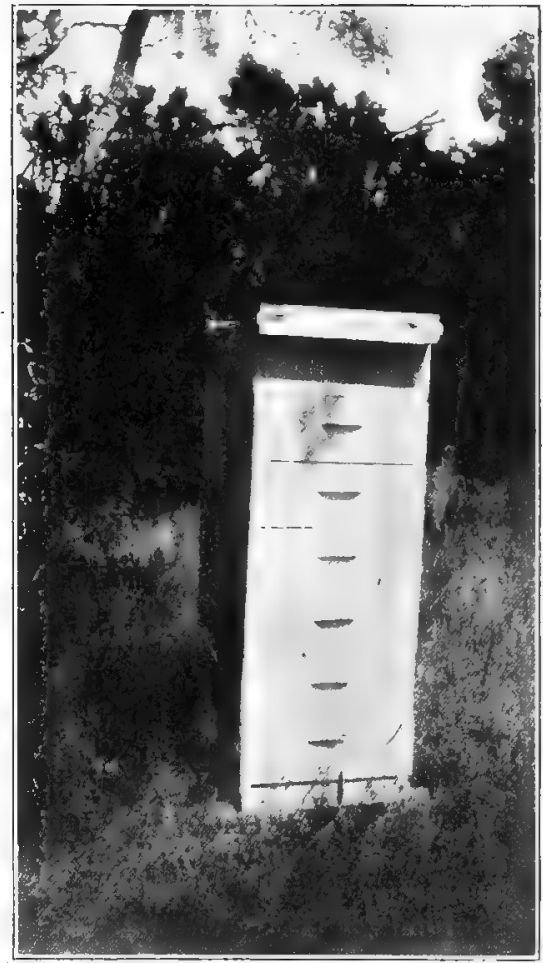

A stack of bulk comb honey. completely across their width, and one stroke uncaps the entire surface. Room can be given to the colonies more gradually, as needed, with the shallow supers. This is a great advantage over using the deeper and larger hives over the colonies that are not able to take care of so much room at one time. The writer is using these shallow supers, and their superiority enables him to accomplish manipulations 
throughout the season that result in larger profits from his apiaries than could otherwise be obtained.

\section{TAKING OFF HONEY.}

The farmer-beekeeper, or the amateur, with only a few colonies of bees, will have no difficulty in taking some nice combs of honey whenever any of them are full. However, there are certain precautions that should be followed. During the main part of the season the supers of honey may be left on the hives, and only so much removed as needed for the table, or as otherwise required. The length of time it remains in the care of the bees improves it in both quality and flavor. In other words, it becomes riper and thicker, or "cures," on the hives.

When examining newly built combs of honey, which are very fragile, and therefore break easily in handling, especially during warm weather, the practice of handling the frames, as illustrated,

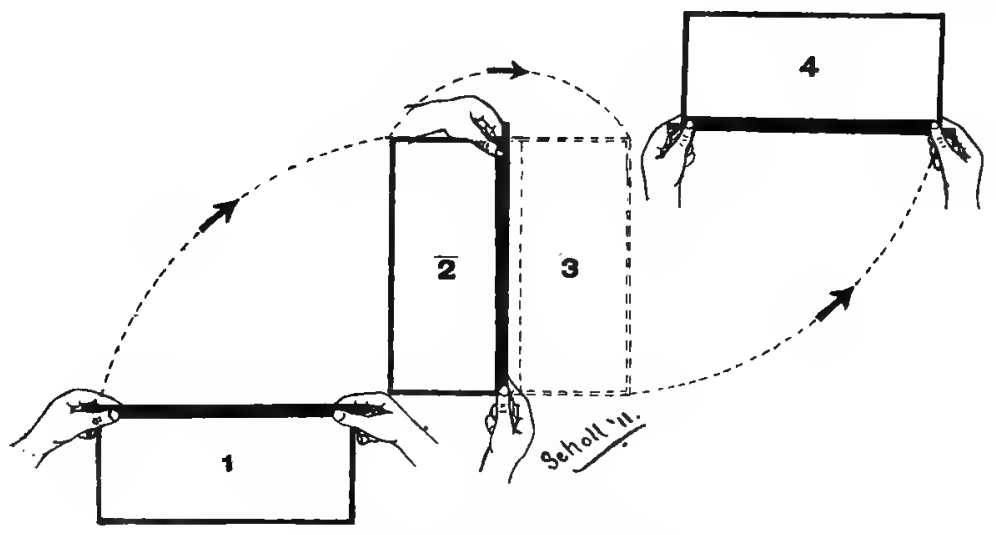

Method of handling the frame.

should be adopted. In fact all combs, brood combs as well as those with honey, should be handled in this way. The trick of handling all combs thus will soon become automatic with the operator and prevent many disagreeable mishaps to the combs. A comb removed from the hive is examined on the side nearest the operator, and is then raised up with the left hand and twirled around to bring the other side forward. The right hand is next raised up and the comb examined on that side. The comb is always kept in a vertical plane, or on -its edges, and never flat. To replace it in the hive, the exact reverse motions are applied, which brings the comb into its original hanging position.

Care must be taken not to leave comb honey on the hive too long after the main season, as the bees soon soil the beautiful white cappings, by continually traveling over them and by adding discolored wax and propolis. The supers should be removed in due season and stacked up in a dry room to prevent this. The combs should be examined occasionally, as the minor wax moth larvae depredate, and 
sometimes the larger "wax worms" also. Their presence can be told by the little dust-like traces where these small "worms" have eaten their way over the cappings. An empty hive should be set under each pile of supers, which should not be too high, and a very small quantity of sulphur be burned in it in a saucer to destroy the larvae, during which time the supers should all be tightly elosed. If cool weather comes soon, no more danger need be feared from them. By keeping the comb honey in a warm dry room during the winter, it will not granulate very readily and comb honey can be supplied for the table at any time.

That intended for extracted honey should be removed before cool weather, as it would then be too thick to be thrown out by the extractor. The too common mistake of removing the honey from the hives too early should be avoided. Such honey is still "green," as it has not been "ripened," or "cured," sufficiently on the hives, and, although it may not sour or ferment, which it has done with some careless beekeepers, it will be very thin and watery, and, therefore, of poor appearance and flavor. A general rule followed by beekeepers is, never to remove honey until the bees have capped over or sealed nearly all the honey cells. During a very dry season, when the water content of the nectar is much less, and toward the end of the summer honey crops, the honey is ripened much sooner and may be safely taken off when the combs from which honey is to be extracted, are two-thirds sealed over. C o m b hon ey, of course, should always be entirely capped.

The general practice is to open the hive, as in all other operations, and, as the combs of honey are removed, brush the bees off with a bee brush or a bunch of long slender weeds or grass. A knack of shaking the bees, or nearly all of them, off the combs can be acquired, and, besides
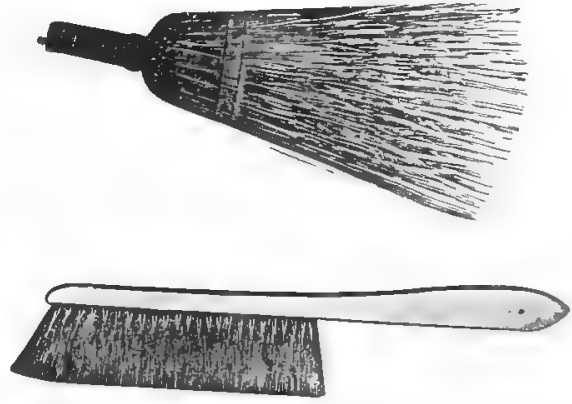

Bee brushes.

being done faster, it prevents irritating the bees with a brush.

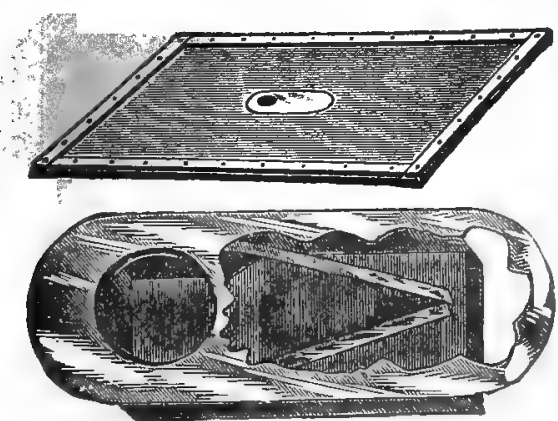

Bee escapes.

Bee escape boards are quite extensively used, these being placed between the full supers of honey and the hive below a day before the honey is to be removed. The bees pass down over night to the hive below, through the metal escape fitted in the center of the wide board, and, as they can not return, the supers are clear of bees and can be lifted right off the hives next morning.

The honey is more rapidly removed if the shallow supers are 
used, and their use is advocated. It is an easy matter to drive the bees down and out of these shallow supers with the smoker in very little time and, when nearly all are out, the supers are removed rapidly and the rest of the bees shaken therefrom. This is by far the most rapid way of removing the surplus honey from the hives, since the

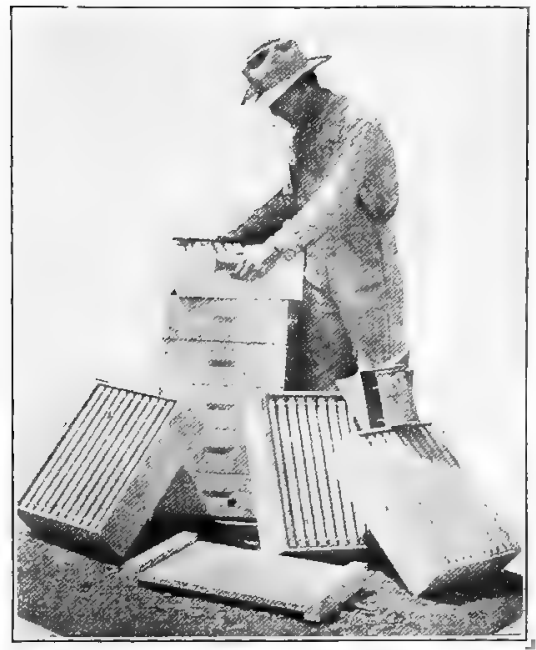

Rapid removal of shallow supers. entire supers are removed, instead of single combs, and no brushing is necessary. It is more rapid than with the use of bee escape boards, since the supers are removed in but little more time than it takes to place the escape boards in place.

When the hives are ararnged properly in the apiary, or, if in groups of five under each tree, the full supers can be removed in a wholesale way from five hives at a time. The bees of each hive are smoked quickly in succession, as the covers are removed, and set against the tree. Returning to the first hive, another rapid smoking is given; and so on with all five hives. Beginning again with the first hive, the uppermost supers are rapidly taken off, and, after vigorously shaking the remaining bees out, are set on the wheelbarrow or honey cart. If another round of supers is ready to be removed, another smoking will be necessary, but as the bees are already on their way down from the previous smokings, they are freed from the second or third round of supers much more rapidly than the first.

By following such "short cut wholesale methods," it is an easy

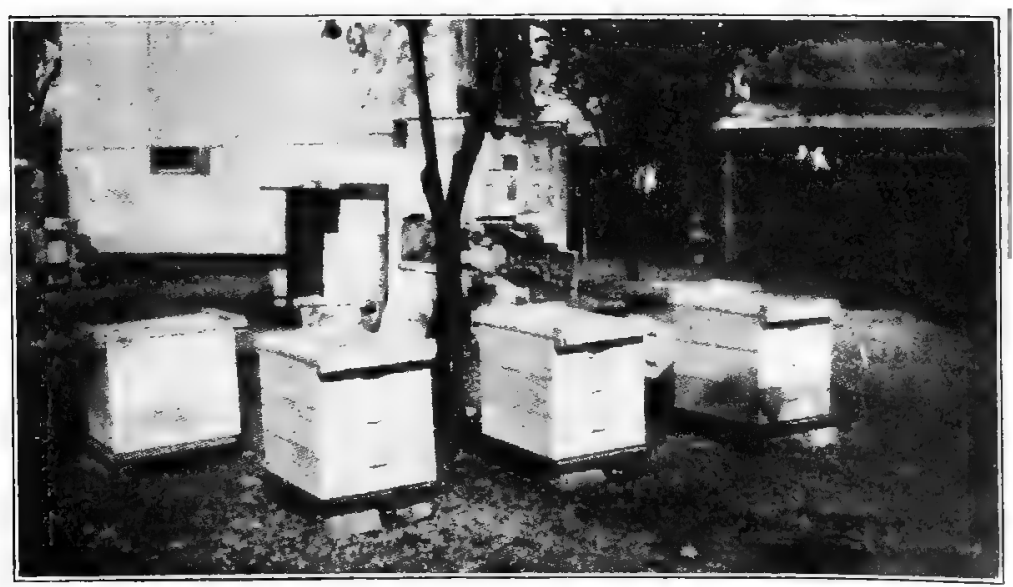

A round of supers of comb honey ready to be taken off. 


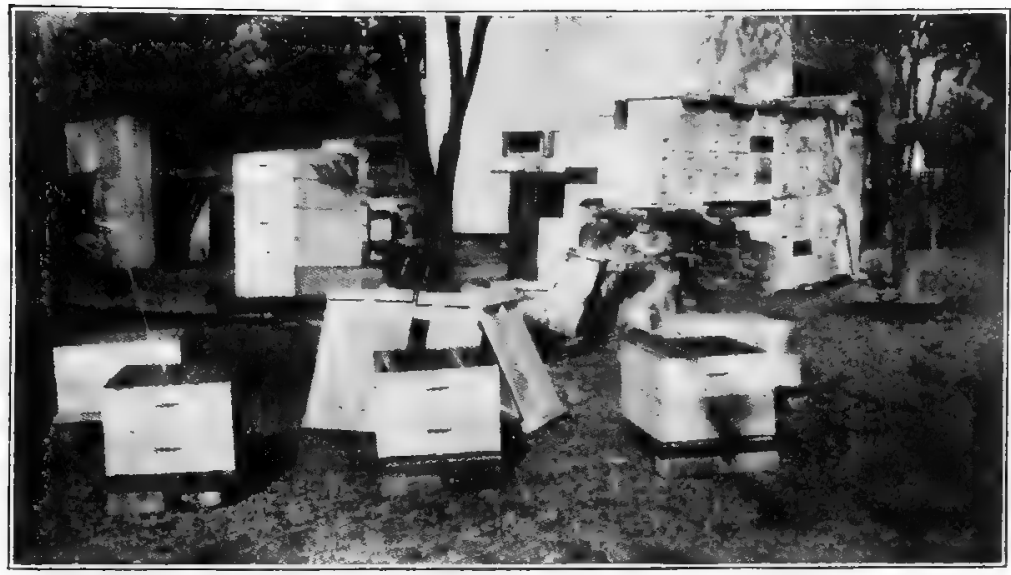

The comb honey off and hives ready for their covers.

matter to remove a thousand or more pounds of surplus honey from the hives within less than an hour's time, thus permitting the rest of the day to be devoted to getting the honey ready for market in the honey house.

\section{HOW IT IS PACKED.}

As the supers of honey are brought into the honey house, they are 'stacked up as high as convenient. From these piles of white waxen honey combs, filled with the most delicious sweet, the cans in which it is shipped to market are filled.

The cases, each holding two 60 -pound square cans, the same as for extracted honey, except that they have large open in $g$ s with eight-inch screw caps, have been in most general use. However, the other regular and popular sizes of packages, 12,6 , and 3 pound friction-top round pails-the two sizes in cases of ten pails each, and the latter twenty to a casehave come to the front very rapidly. Handling honey in the original packages is coming more in vogue, and, as that is the proper way, it should be encouraged by beekeepers.

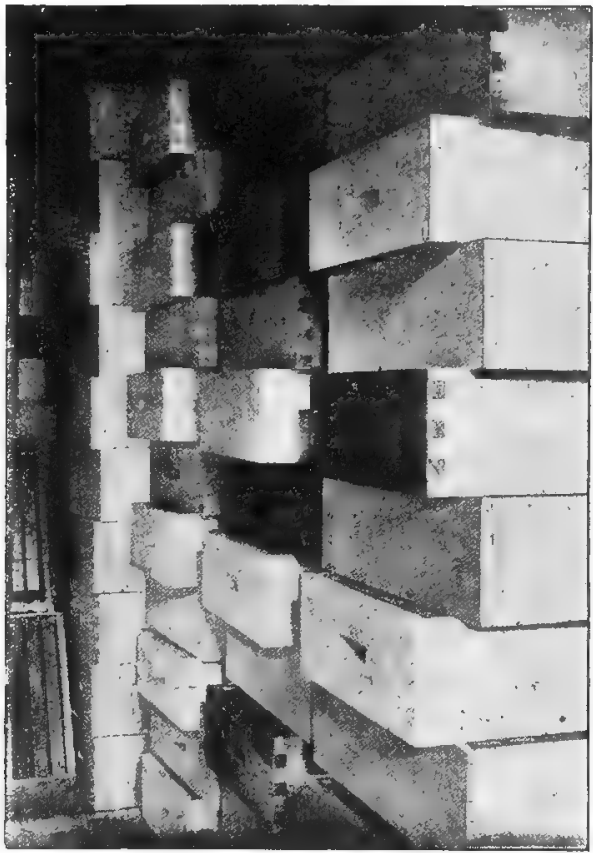

Tons of delictous honey. 


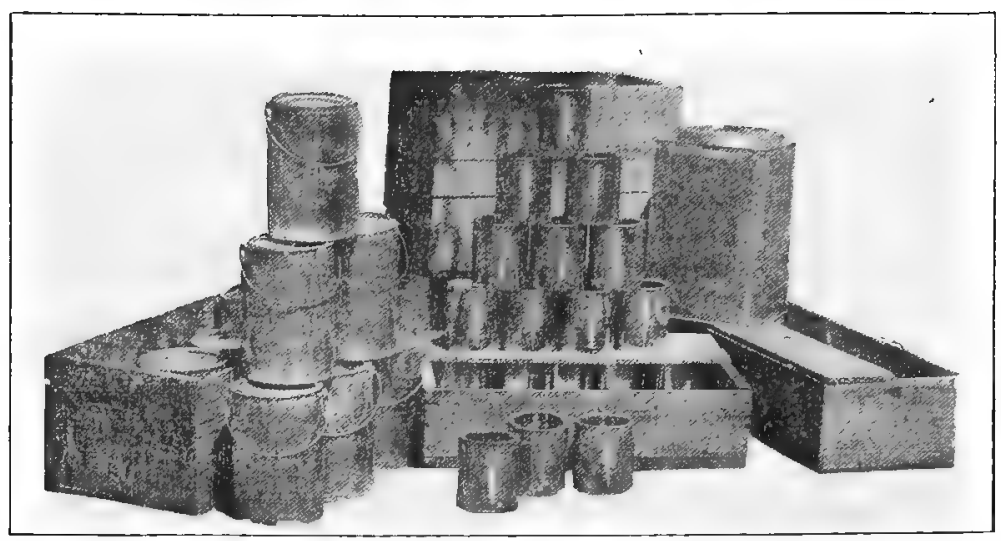

The various sizes of cans.

In packing honey, the frames with the combs are placed on a sixinch board laid across a large shallow tray, or on one of the tubs used in extracting work. This catches all the drip and bits of comb and other waste. The knife is run around the inside of the frame to cut the comb loose, and the frame is then put back into an empty super, later to be scraped clean with all the others, for future use.

For the large square cans, the combs are cut across the middle, and the two halves laid flat, side by side, make a layer in the can. The next layer is placed cross-wise of the first, and so on until the can is nearly full. One ten-frame super, with its ten combs, will fill

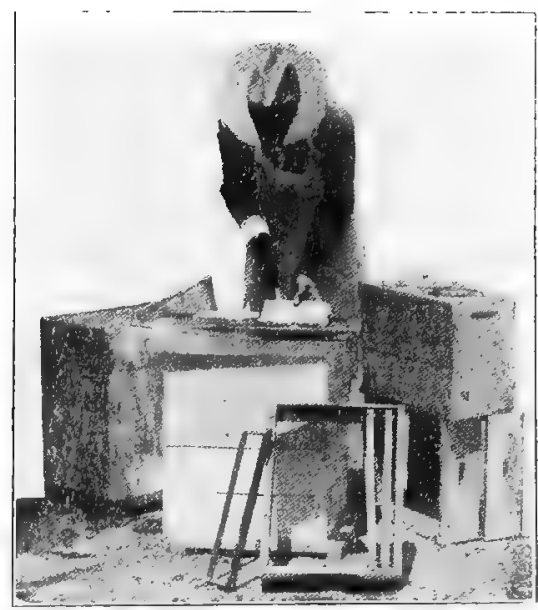

H Jw it is packed. a can. The combs are cut across into four equal pieces for the 12-pound pails, or five pieces for the 6-pound and placed in layers in these until nearly full. For the small 3-pound cans, the comb is first cut lengthwise from end to end about one inch from one side; then cross-wise at equal distances into six pieces. This makes six small squares of comb, and the same number of half squares of the one inch strip first cut off. In packing these into the cans we first place two of the smaller pieces, or half squares, side by side in the bottom of the can, then lay two of the squares on top of these. In this way three cans can be filled with each comb.

Extracted honey is then poured over the comb honey to fill up the crevices and empty space, and make up the weight. It also keeps the comb honey in a buoyant state, so that it does not mash up in ship- 
ping. It is advisable to make it a practice to always heat extracted - honey before putting it on the market, as it prevents granulation for a much longer time. The liquid honey is filled in quite warm, and the cans are immediately and tightly closed. Nothing but firstclass honey should be put up for the market under any circumstances. If this policy is adhered to, a profitable trade ean soon be secured.

\section{EXTRACTED HONEY.}

An average yield per colony, well situated in a good locality, should be at least 100 pounds of extracted honey. During favorable seasons, and where the bees ean be gotten into the best possible condition for the honey flows, this can even be doubled, or better. This is meant as an average per colony for an entire apiary. Some colonies, especially strong, may gather as much as four or five hundred pounds of extracted honey in a single season, if rightly managed. A sufficient supply of empty combs, given at the right time, so that the bees will have all the room needed, will help much tward accomplishing this. At the same time, there will be colonies in the same yard that will not reach above the hundred pound mark, if that much, thereby bringing the average for the entire apiary down to one hundred pounds, more or less, according to the season.

Two styles of supers are in general use for extracted honey production, and for a long time it was customary to use the same deep hives for supers as for the main hive body or brood cham. ber below. In more recent years, the shallower supers have become very popular, and their use for extracted honey production, as well as for comb honey, is on the increase. The finished product is removed from the hives the same way as described under "Taking Off

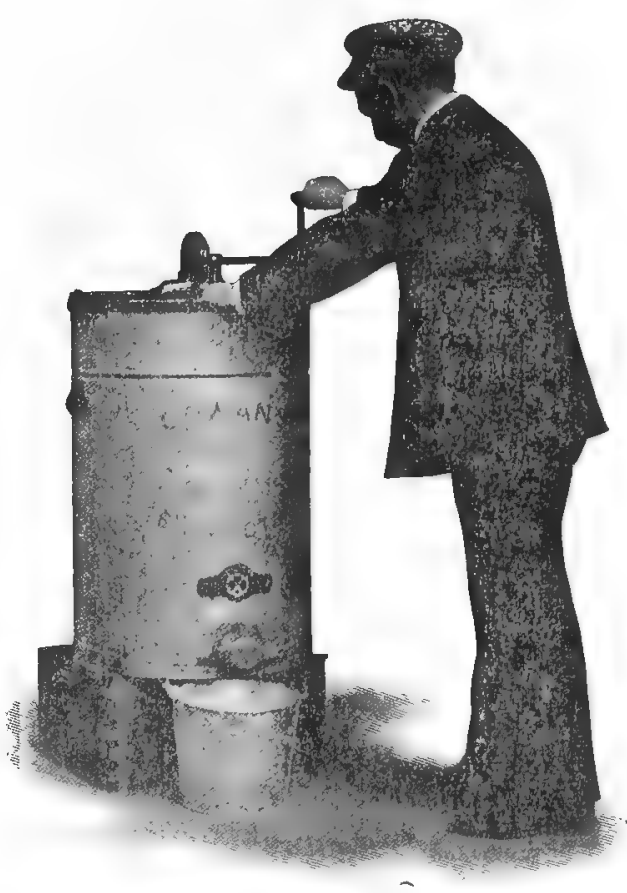

Extracting honey. Honey," and stacked up in the honey house.

The extractor should be of such size that the baskets will properly take the frames in use. Those most commonly employed are the ones with baskets, wide enough to take the regular deep Langstroth frames, generally known as the No. 15 size; but, since these baskets are too narrow to hold two of the shallow frames, $5 \frac{3}{8}$ inches in 
depth, it is recommended that the next large size, the No. 17 , with eleven inch wide baskets, be purchased. Although the price is slightly higher, the advantages of being able to extract two of the

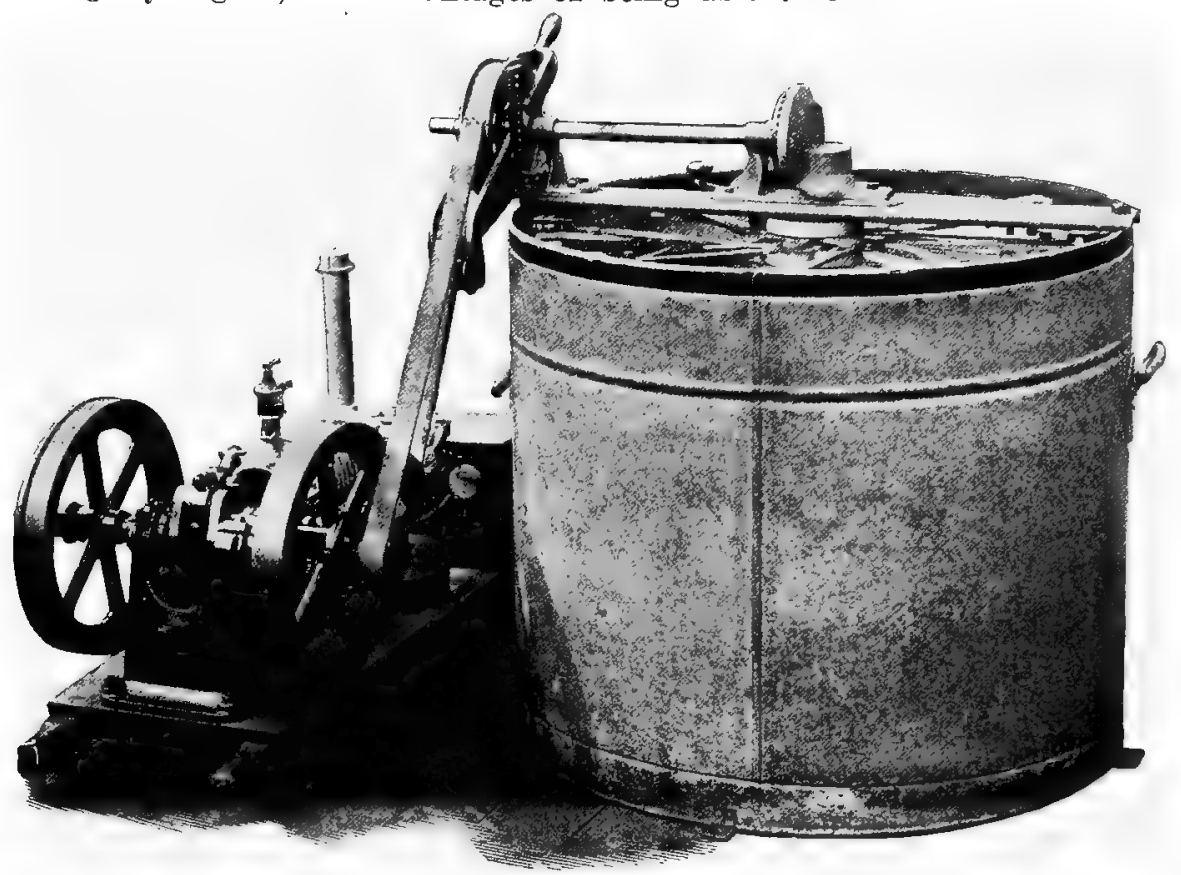

A large power honey extractor harnessed with gasoline engine.

shallow combs in each basket instead of only one, if the beekeeper adopts such frames at any time, or of making it easier to dispose of if desired, overbalances the difference.

The two-frame size is sufficiently large for the average beekeeper. The larger extractors are difficult to operate by hand, and it is only the extensive beekeeper, with large numbers of colonies of bees, who can practicably install the large power machines.

Before honey can be extracted from the combs, the eappings must be removed, and special uncapping knives are used for this. A com-

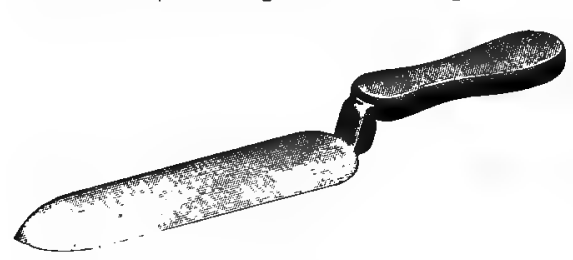

Uncapping knife. mon, very sharp, butcher knife, however, can be used for the purpose just as well. The combs are shaved off over an uncapping can and fall on a screen, so that the honey drains off and eollects below, where it may be drawn off. A home-made and far less expensive arrangement is constructed out of two common tubs, by replacing the bottom of one of the tubs by coarse screen wire, bracing this well from below, and supplying the other with a honey gate. A plain narrow board at the top, with a nail 
driven through, serves as a pivot on which to support and revolve the combs in uncapping.

The uncapped combs are placed in the baskets of the extractor and rapidly revolved, so that the centrifugal force causes the honey to fly out against the wall of the extractor. This accumulates below and is drawn off into a pail or large can. As it contains many small bits of comb and wax, it is necessary to strain it. The general way is to pass this honey through a straining cloth over a large storage tank especially constructed for the purpose. Another tub may be used for this by the average small beekeeper. Instead of sewing the cloth to a large hoop, which is preferable to tying it over the top of the tub, a piece of one inch mesh poultry netting placed over the tub and pressed down slightly, over which a square yard of strainer cloth is simply laid, serves the purpose most admirably. This gives an opportunity to remove the eloth quickly, when necessary to be washed, and for it to be easily replaced.

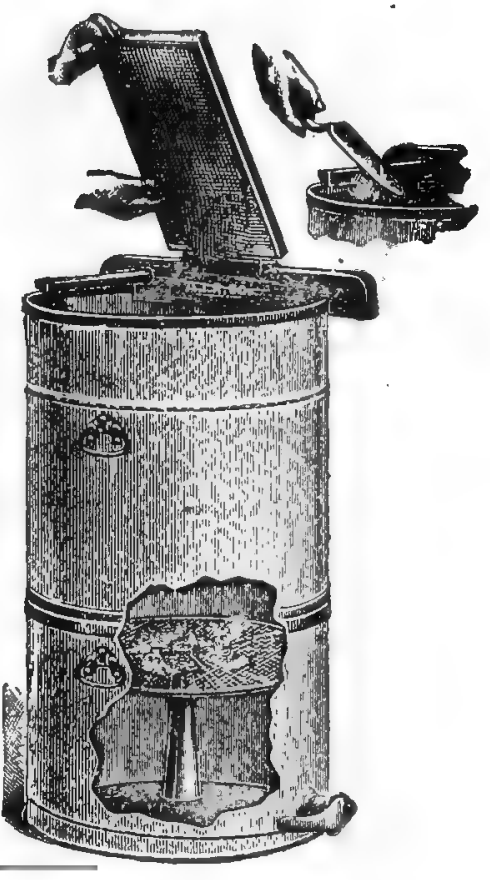

Uncapping can.

Various other methods of straining the honey are employed. Some beekeepers do not strain it at all, but use large honey tanks, in which the particles rise to the top and the clear honey is drawn

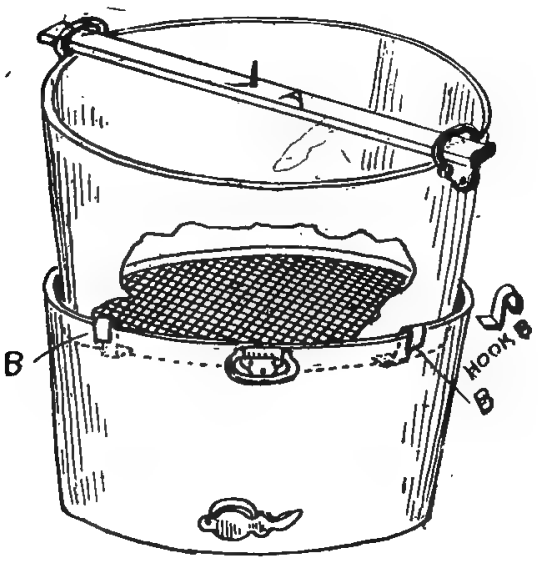

Home-madè uncapping can. off below. Care must be exereised to allow sufficient time for this. It is a credit to the apiarist to produce an absolutely clear and sparkling article for the market, and it will prove an advertisement in every instance.

Extracted honey is put up for market mostly in the regular square five-gallon, or 60-pound, tin cans, generally packed two in a wooden box or case, although some single cans in a case are used. In Texas, however, the friction top pails are much used also. In the cities, much honey is put up in various sizes and kinds of small glass jars, bottles and tumblers. Much extracted honey is used in packing bulk comb honey in the various styles of packages in which it is marketed. 


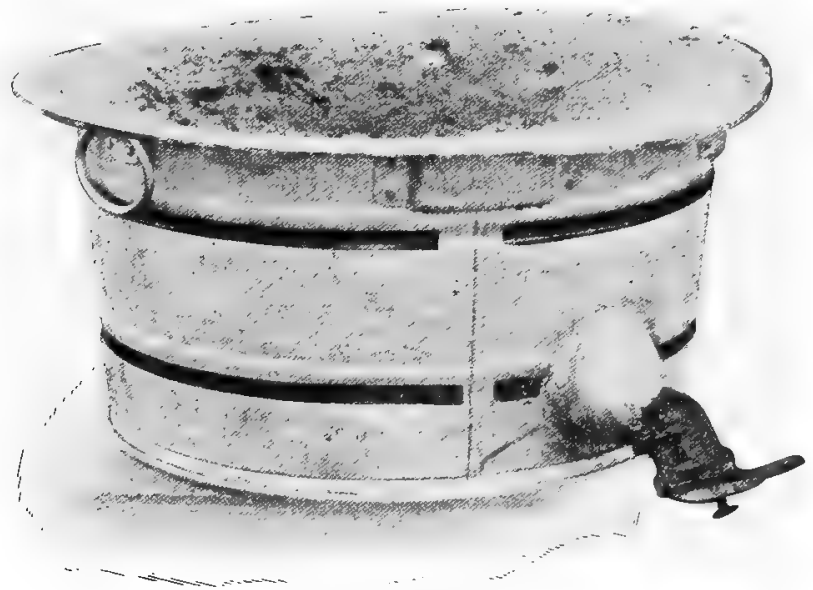

Home-made strainer tub.

\section{MARKETING HONEY.}

In many cases the home market will prove a good place for the average beekeeper to dispose of a crop of honey, especially if it is not a large one. This market should be cultivated first, in all instances, save where it is already supplied. Neighboring communities should next be visited, and, if the people are properly approached and the value of honey as a food exploited in the right manner, much of it will not only be disposed of, but at a good price. This is by far the wisest plan, and if more beekeepers would follow it, instead of shipping their honey to the general market, a more universal use of honey would be established, and, being distributed much more properly, would result in better honey prices. This applies to a vast number of beekeepers, except in some of the best beekeeping sections of Texas, where honey is very plentiful. An advantage is, that the retail price of two or three cents more per pound than the general market price, received in this way, not only pays the beekeeper well for his trouble, but increases his net profit. However, the disposition of a honey crop, especially if it is a large one, often becomes a serious question with some beekeepers who are good producers, but very poor salesmen. Fortunately, there are a number of honest and reliable honey buyers in Texas, who purchase large quantities of honey, frequently entire crops, large or small. This affords an outlet for any honey that is left after the home market has been supplied. As a rule, when these buyers purchase whatever quantity of honey the beekeeper has to sell, they send him shipping instructions, together with properly addressed tags, and he bills it directly to them.

The price received by the prodncer is usually $1 / 4$ to $1 / 2$ cent lower than that obtained by the honey buyer, this being the latter's commission for his part in the disposition of the honey. An advantage of this method to the beekeeper is that, although the price received may be a little less, he can sell his output with little trouble after it 
is produced, and then devote his time to other things that may be worth more than the difference in the price obtained.

A large number of beekeepers ship their honey direct to jobbers, retailers, or consumers, as the case may be, instead of selling to the honey buyers. This enables them to get a good price for their crops, as they receive the difference in the price of honey or, in other words, save the middle men's profits. It takes time and experience for a beekeeper to work up such a market for his product. Once obtained, however, and always supplied with a first-class article of honey, it is not difficult to not only hold the trade, but advertise him so favorably that the demand for his product will increase from year to year.

Never ship honey to a commission man on commission. Although there are honest commission merchants in the state, that is not a practice in Texas. When honey is shipped to a distant market, every precaution should be taken to ascertain whether it is going to a reliable dealer.

\section{LOW HONEY PRICES.}

Compared with most other commodities that come in the same class as honey, the price of honey is lower than it ought to be. Although the argument is often made that this is due to honey being a luxury, rather than a necessary, it is not well grounded. There is little doubt that, with the proper and more general distribution of the honey crop, the price would be higher, which it should be-if for no other reason, because it is one of the most nutritious, healthful and economical of all foods.

The beekeepers are much to blame for the low prices of honey. One cause is that a large majority of them dump their honey crops on the general market at about the same time. This keeps prices down, as would be the ease with any other commodity if so disposed of. By keeping more of the honey off the general market, and distributing its sale over vast areas where it is seldom found on the tables of consumers, for no other reason than that it has never reached these places, the prices would be better. In this connection, judicious advertising and education regarding the true value of honey would help much.

A more serious reason is that of some producers quoting their honey lower than the general market prices. There is no excuse for this, except in the case of the inexperienced beekeeper who does so for lack of knowledge regarding the honey markets and prices. Whatever the cause, the evil effects of such action are the same. It is advisable for new as well as veteran producers to keep posted by reading bee journals. The beekeeper who does not read one or more bee journals is nearly always a detriment to the honey market, while the extra price that might be obtained by perusing them would pay for more than a dozen subscriptions. However, there are some beekeepers with experience who are guilty of keeping the price of honey down.

It is to be regretted that the blame for the low prices of honey, as compared with other similar commodities, rests with the beekeepers themselves, and it is hoped that the time is not far distant when a stronger effort will be made toward remedying this fault. Co-operation in the direction of raising the prices of honey gradually to a 
proper level would mean much for the honey producerss and the beekeeping industry.

Conditions in Texas are such that it is not necessary to quote honey lower than the prevailing market price. On the contrary, demand is so brisk that the entire Texas honey crop is disposed of and the market bare of honey long before the winter is reached.

\section{A HONEY PRICE LIST.}

Nearly all the leading beekeepers of Texas ship their honey and sell direct to retailers and consumers. Each year, just before the honey is ready to be shipped, an annual price list is sent to former customers and others whom it is thought may wish to buy. There are a number of customers who have always received fair treatment, and, therefore, order their supply of honey year after year. As time goes on, the list is increased by reputation for fair dealing and giving satisfaction.

Price lists may be prepared in various ways. While some use only postal cards that are very brief, others send either personal letters, or, as is now so much in vogue, circular letters, which make it possible to go more into details concerning the quality of the product offered. For the information of readers who may desire to adopt the regular price list, the following is suggested for postal eards:

\section{Choice Comb Honey.}

We are quoting you F. O. B., here, sight draft attached to bill of lading:

60-lb. cans with 8-in. screw caps, 2 in a case, per lb.......11c

12-lb. friction top pails, 10 in a case, per $1 \mathrm{~b} \ldots \ldots \ldots \ldots \ldots . \ldots \ldots 11 / 2 \mathrm{c}$

6 -lb. friction top pails, 10 in a case, per $1 \mathrm{~b} \ldots \ldots \ldots \ldots \ldots 12 \mathrm{c}$

3 -lb. friction top pails, 20 in a case, per $1 \mathrm{~b} \ldots \ldots \ldots \ldots \ldots . \ldots \ldots 121 / 2^{\mathrm{c}}$ less.

Extracted honey in the same sizes of packages, 2 cents per pound

Soliciting your early favors,

Yours truly,

A personal, or circular, letter may be similar to this:

Dear Sirs :-

We have some honey to offer that is excellent in quality and flavor. A trial order will convince you.

It is an advantage to you to buy your honey direct from a producer that you can depend upon, as you do not only know what you get, but save the middle men's profits.

We guarantee every pound of honey we ship out to be absolutely pure honey, under both State and National Pure Food Laws. A sample will be mailed for 10 cents, and may be deducted from the amount of the first order.

\section{Extracted Honey.}

60 -lb. cans with $15 / 8$ in. screw caps, 2 in a case, per lb...... 9c 12-lb. friction top pails, 10 in a case, per lb......... 91/ac 
6-lb. friction top pails, 10 in a case, per lb............10c

3 -lb. friction top pails, 20 in a case, per $1 b \ldots \ldots \ldots \ldots \ldots 101 / 2 \mathrm{c}$

\section{Comb Honey.}

- 60-lb. cans with 8-in. screw caps, 2 in a case, per lb.........11c

12-lb. friction top pails, 10 in a case, per $1 b \ldots \ldots \ldots \ldots \ldots . . . \ldots 11 / 2 c$

6-lb. frietion top pails, 10 in a case, per lb.............12c

3 -lb. friction top pails, 20 in a case, per $1 b \ldots \ldots \ldots \ldots \ldots 12 \frac{1}{2} \mathrm{c}$

Our terms are F. O. B. our shipping points, sight draft attached to bill of lading, subject to examination.

Trusting that we may hear from you if you are in need of good honey, or that you will remember us in the future when you may need some, we are,

Yours very truly,

Every beekeeper must necessarily change the wording in connection with the price lists to suit his individual requirements. It may be well to say that too much should not be expected from the efforts thus made toward securing buyers, as it is not uncommon for dozens of these letters not to bring a reply. Yet a single one of them may secure a customer for all the honey on hand, and perhaps a permanent customer for many years.

\section{SHIPPING, SIGHT DRAFT ATTACHED.}

There is considerable risk connected with filling orders and shipping honey to persons or concerns that are not known to the beekeeper, unless cash accompanies the order. This practice is followed by very few buyers of honey, especially retailers, and even individual persons rarely send money with their order. The fact that it is not always certain whether the orders can be filled by the beekeeper, and the consequent inconvenience of having the money returned, together with a certain degree of distrust on the part of the purchaser, has made the "strictly cash with order" business an impracticable one.

But it is not advisable to simply ship one's honey, produced by many days of hard toil, to unknown buyers without having some assurance of receiving pay for the honey. For this reason the practice of shipping C. O. D., or sight draft attached to bill of lading serves a useful purpose. Although this method of shipping was not popular several years ago, mainly because the buyers did not favor the idea of the binding effect, the objections to it have waned. It is the only absolutely safe way, and it has been adopted by quite a number of beekeepers.

The honey shipment is billed out on a special form or "shippers order" bill of lading, which consigns the honey to the shipper himself at destination, but immediately under this are the words, "notify at .........." in which the purchaser's name and address are filled. This bill of lading is then taken to a bank, together with a statement showing the amount of the order filled. Upon request the banker will write out a sight draft, and after it 
is signed by the beekeeper, attach it to the bill of lading which has been properly endorsed by the shipper, and send this to the nearest baak to the buyer. To obtain the honey it will be necessary to pay for it, or the amount of the sight draft, in order to secure the bill of lading, without which the honey can not be obtained from the railroad company. Thus the honey is still the property of the beekeeper until the buyer has paid for it at the bank. If such a shipment is refused the bank will return the draft and notify the beekeeper, who can then have the honey reconsigned to another buyer from whom he may have an order, by presenting the matter, with the original bill of lading, to the agent at his own shipping point. This saves having the honey returned, unless oue has no other orders for it, in which case storage charged by the railroad company, after a certain length of time, will accrue. Hence, disposition of the shipment should be made immediately. Such refusals are not common; but, if they do occur, it is better to be out the freight and storage and still possess the honey, than to let some dishonest person have it.

\section{SHIPPING HONEY.}

Usually honey is shipped with no loss whatever if the proper precautions are followed in packing it. Most extracted honey is shipped

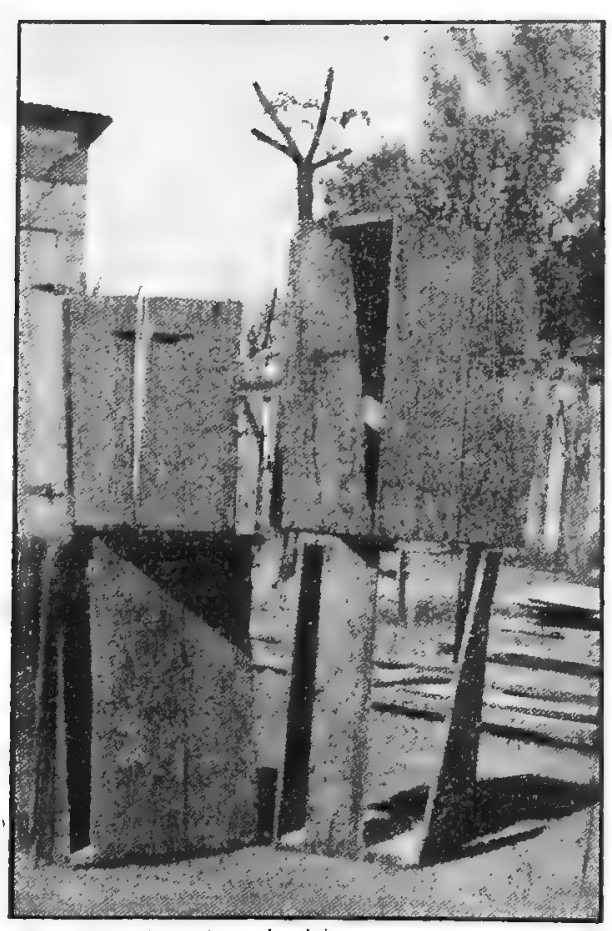

Lllipldaled shipping cases. in 5-gallon, or 60-pound cans, two in a case, and some in friction top pails of various standard s.zes. Not so much is now shirped in barrels as in earlier years, only inferior grades of honey being put up in that way. Their use is not advisable. Bulk comb honev is always shipped in the various styles of standard cans and pails, put up in cases. However, the two sixtypound can cases are not so popular now; the friction top pails are much more in demand.

Shippers of honey are cautioned to use nothing but first class cans and strong wooden cases. Most of the cases on the market are too frail to carry heavy cans of honey in them, and reach their destination in a very dilapidated condition In some instances that have

come under my observation, the cases were almost entirely torn off the cans of honey, giving them practically no protection, and they were consequently smashed up to such an extent that part of their contents leaked ont. 
This matter is a very serious one. The beekeeper does not feel the loss and the damaging effect, and hence his neglect of effort toward remedying it. The result is, that many buyers of honey become discouraged and cease handling it because they are not able to get honey shipments without more or less loss from damage. The beekeeper seldom has opportunity to know the facts, because he never hears of the condition in which his honey was received; neither does he learn the number of claims for honey shortages received by the railroad companies at the destination of the shipments.

A close study has revealed that hundreds of honey shipments are damaged to some extent each season, and the consequence will be a serious one to the beekeeping and honey shipping industry unless remedied. It was ascertained that during a period of less than one month there were twelve claims made to one railroad company for damaged honey shipments and loss by leakage. This was between the dates of August 14 and September 10, a period of 27 days, long after the main honey shipping season. Considering the numerous other railroads and the thousands of other honey shipments, it is evident that this matter should be taken in hand and remedied at once.

It is hoped that the beekeepers, small and large, will assist in reducing this damage by using nothing but good, well-made honey cans and pails, boxed securely in strong well nailed wooden cases that will carry the heavy contents in first class condition to the purchaser.

To neglect this, will ultimately mean disastrous results, in that many buyers will refuse to handle honey at all, and, more serious than this, is the fact that the railroads have threatened to refuse to carry honey improperly boxed, or to raise freight rates for its transportation. As all honey in cans properly protected in wooden cases goes at a very low (fourth class) freight now, it behooves beekeepers to take warning and keep it so.

\section{GRANULATION OF HONEY.}

Nearly all pure honey will become hard and white as soon as cool weather approaches. Some persons look upon this with suspicion as being a sign of adulteration of the honey with sugar, or otherwise. On the contrary the granulation of honey is a sign of its purity, as adulterated honey, especially that to which glucose has been added, does not granulate or become solid.

While many persons like, or even prefer, granulated honey, it is easily made liquid again by simply setting the vessel into a larger one filled with water on the stove, and heating slowly until the honey is entirely liquid. Some thin pieces of wood should be placed under the bottom of the vessel of honey to prevent scorching, and it should not be heated too long or the aroma of the honey may be spoiled.

Some honey granulates much more readily than others, and, unless the beekeeper is very sure that the honey will not granulate for a long time, all the extracted honey must be heated to the temperature of 152 degrees Fahrenheit. It is mutually understood between producer and buyer that honey must reach destination in the liquid form, unless granulated honey is especially ordered, and a virtual 
guarantee is, that it will not granulate within 30 days after shipping. Although it is not always necessary to heat all honey at certain times, it is well to be provided for it. While a single can at a time is heated in a wash boiler, either on the kitchen stove or an out-door fire, the result is slow and requires the burning of much wood. A far better method is to make an improvised furnace, as here shown.

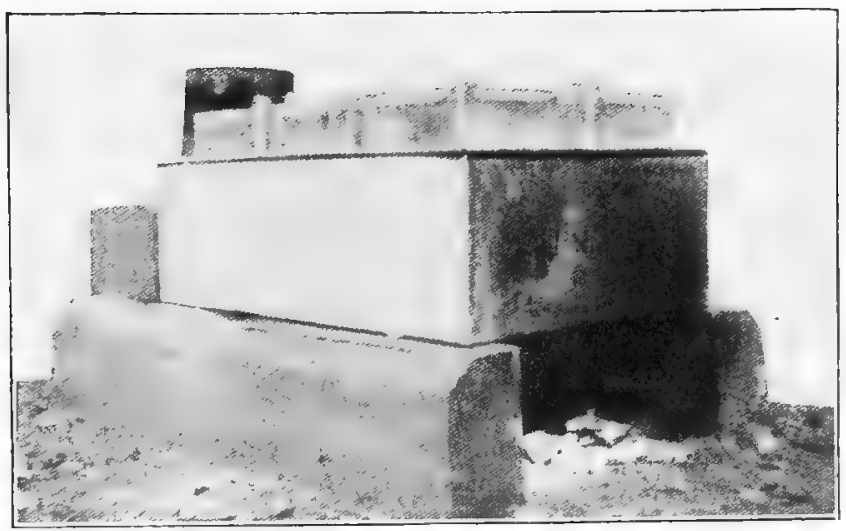

Honey liquifying vat.

It is constructed of several concrete blocks, simply laid together. One with a hole through it and a round lard can with its bottom removed set over this, serves as the chimney. The large vat holds six cans which rest on a wooden frame so that the honey does not scorch. It requires very little fire and attention. The cans must be left open to prevent bursting.

Although some honey can stand more heat than 152 degrees Fahrenheit, it affects the color and mild flavor and aroma of most honey, hence care should be taken not to injure these by overheating.

\section{SWARMING.}

A natural desire to multiply their kind is the canse of bees swarming. When a colony becomes crowded, or other conditions, that man does not fully understand, exist, preparations for a division of the colony and the establishing of a new home are made. The first evidence of this to the apiarist is the appearance of queen cells in various stages of development on the brood combs. Ordinarily when these cells are sealed and the weather conditions are favorable, the colony will swarm. Bad weather may delay the swarm several days. However, bees may swarm before the cells are sealed, or, as is frequently the case with Italians, before the building of cells has begun.

Swarms, as a general rule, issue during the warmest part of the day, between 9 a. $\mathrm{m}$. and $4 \mathrm{p}$. $\mathrm{m}$. Just previous to the issuance of one, the colony will not be working as usual, while inside the hive a great commotion exists. All at once the bees come pouring and tumbling out of the hive entrance with a rush, as if pursued by some- 
thing, and take wing immediately, to fly around with thousands of others, in a manner that makes one dizzy to watch. The queen does not lead them out, as many suppose. In fact, she is often among the last to come forth from the hive. It is always the old queen that goes with the first prime swarm.

There is no rule that governs which of the bees shall go with the swarm or which shall remain in the old home, consequently, bees of all ages are found in each division. Bees, so young that they can not fly, may be found in front of the hive trying to join the swarm, but unable to do so, and within the hive will be found bees ranging from those just emerging from the brood cells to the very oldest, shiny and almost worn out bees.

The swarm will circle around in the air, sometimes shifting from one part of the apiary to another, and often some distance from it, before alighting, while in other instances the bees alight almost at once. The noise made by a swarm is a characteristic, loud one, very much like that of a rapidly running machine heard at a distance. Usually the alighting place is on a limb of some low growing shrub, or other object from which the swarm can very easily be shaken off in front of the entrance of a hive and allowed to run into their new home.

It is very disagreeable for swarms to cluster high up in tall trees,

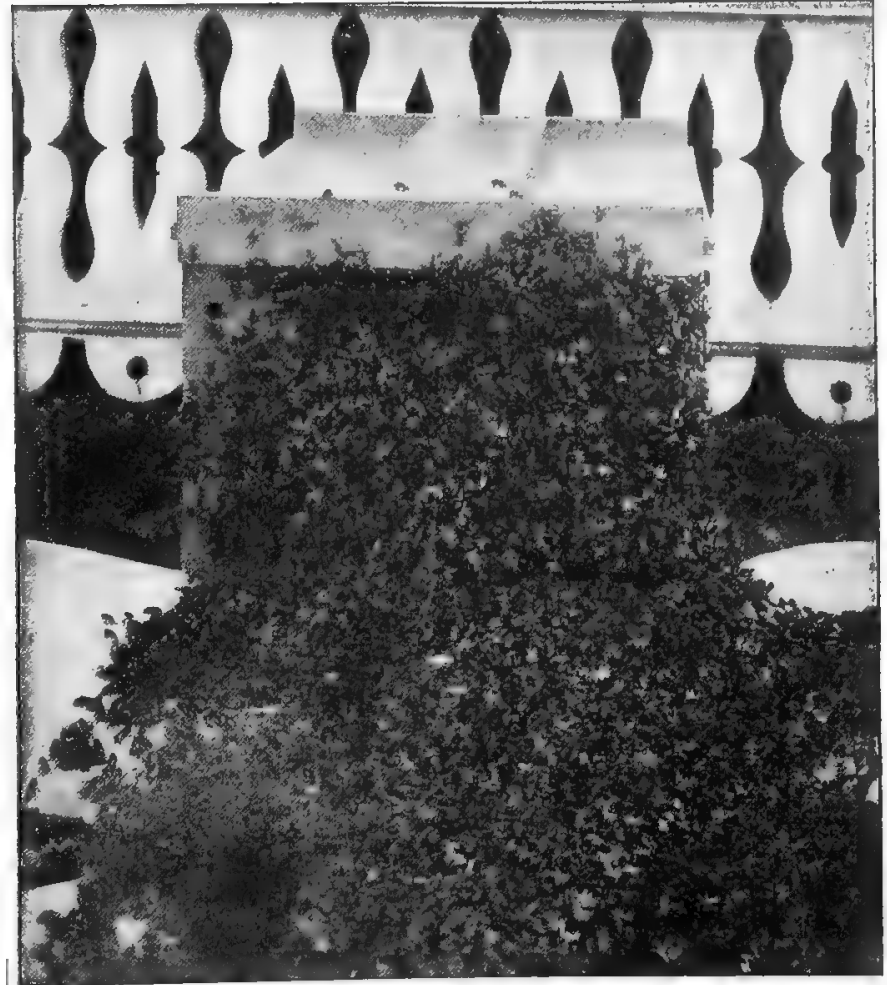

A swarm entering its new home. 
necessitating climbing after them. If clustered on a small limb this may be sawed off and lowered to the ground by means of a long rope. Valuable trees need not be injured in this way, however, because the swarm may be shaken or brushed into a light basket or box, quickly covered over with a large cloth and brought down and hived. A convenient contrivance for this purpose is the swarm catcher, with a long pole, which enables the apiarist to get down swarms from high places. It is only necessary to get the biggest part of the swarm of bees into the

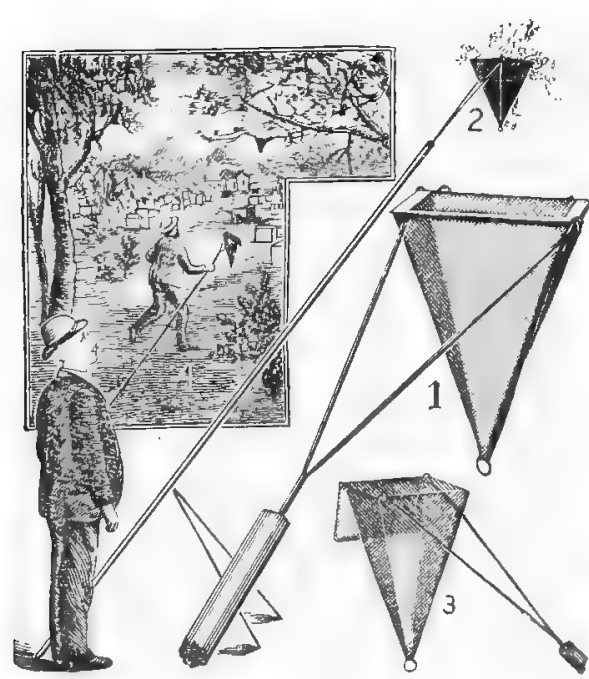

Manum swarm catcher. basket, when it is lowerel over a limb in such a way that the lid will be thrown over the top of the wire basket and confine the bees. It is then by means of the tripod legs, suspended in the air near the flying bees, and these will cluster to the outside of the basket.

In the mean time a hive for them is prepared on the stand from which the swarm issued, after removing the old hive to a new stand. The swarm catcher, with the bees, is carried to this and "dumped" in front of the hive entrance through which they will enter the hive immediately.

As swarming bees are always well filled with honey, to last them on their journey, they are not inclined to sting when hived, unless roughly handled, and need not be especially feared. This makes it possible for the larger children, or the "women folks" to hive the swarms, in the absence of the beekeeper.

\section{SCOUTS BEFORE SWARMING.}

A first, or prime, swarm very rarely fails to alight before going to the place where its future home is to be. Whether this clustering is done to perfect better organization of the forces that make up the emigrating swarm, or whether it is for the purpose of sending out "scouts" to look for a suitable place to which the journey may be made, is merely guessed at by man. Apparently there are many evidences that a colony of bees, preparing to swarm, will previously select a location for a new home by sending out "scouts," or a number of bees to go out and find a suitable place, to which the swarm proceeds later. It often occurs that quite a number of bees will be discovered searching about a pile of empty hives or supers, only to suddenly disappear and to be followed by a swarm of bees a week or so later to make their abode in the selected place. The same has been 
observed in hollow trees, where it was thought a "bee tree" had been discovered, but closer examination frightened the bees away by the disappointed discoverer. In many cases a swarm was found in possession of the same hollow tree soon after.

In one instance bees were issuing back and forth from a knot-hole in the wall of a building, right under the eaves. But after a few raps were made on the wall they soon dispersed. As a forethought, or fearing that a swarm might enter there, the opening was closed with soft soap. Seven days passed by when, about noon, a roaring noise, near the building, proved to be a very large swarm, which was trying to enter the knot-hole in the wall. They finally settled on a small tree near the building, and were hived.

Whether all colonies send out such scouting parties, or whether certain colonies always do, would be hard to determine. It is known that they do this very often, however. These parties vary in numbers. Most of them are composed only of two dozen bees or more, while the one mentioned above consisted of quite a large number of bees, resembling very much a miniature swarm. The actions of the bees, however, were very much unlike those of a swarm.

It is therefore important that the swarms be hived immediately upon clustering, and then moved away to the stand to be occupied, so that returning scouts, if any have been sent out, will fail to find the swarms and hence prevent them leaving for the selected abode.

\section{SWARM PREVENTION.}

The amateur looks upon natural swarming with delight, so he may count his hives in greater numbers, and it seems to him the only way of increasing his bees. The experienced beekeeper, however, regards natural swarming as a real nuisance, especially if his colonies run up into the hundreds, scattered in several, or many, apiaries. This is due to the fact that it requires a good deal of watchfulness and much hard labor, on the part of the apiarist, during the swarming season, for excessive swarming may not only cause a loss of bees, but a greater loss in the honey crop on account of the weakened forces to gather it. Swarming is, however, known well enough now so that it is no longer feared as it used to be, and, although it may always be a hindrance to a more or less extent in keeping a large number of apiaries, and the production of the greatest amount of honey, it can be so regulated and controlled that beekeeping is profitable. Many methods are employed by which the end of swarm prevention may be achieved.

One of the chief requisites is a large hive, so manipulated that the bees may be kept at work and contented. A cramped brood nest, in which the egg laying room of the queen is restricted, and the otherwise crowded condition, the lack of storing room and improper ventilation of the hive, are all factors tending to produce the "swarming fever." By looking after these details properly it can be held in check to a marked degree.

Ventilation can be given by increasing the size of the entrance, simply placing a small stone or a piece of wood under the front of the hive after it has been raised by inserting the hive-tool into the 
entrance and lifting the hive up. This will also give the bees a better passage-way into and out of the hive during the busy working season. Shailing the hive will aid in cooling it and will also help to keep down swarming.

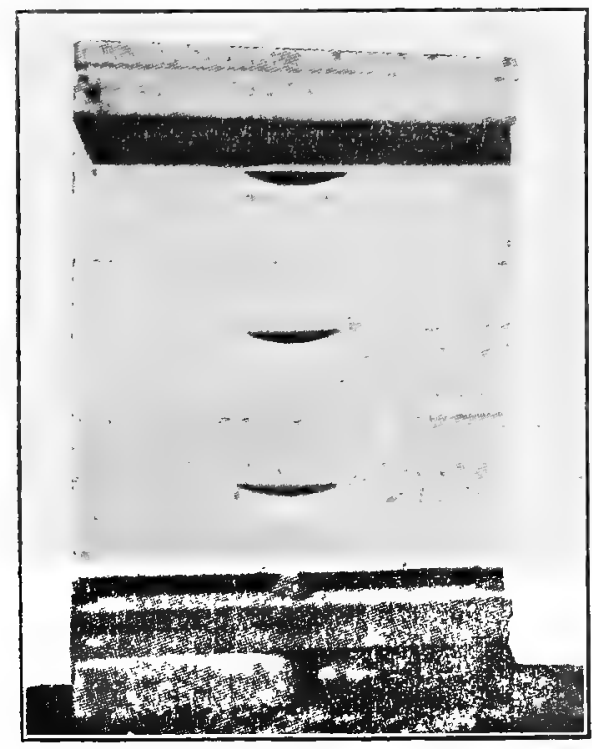

Stone in entrance for hive ventilation.

Swarming can be delayed in many instances, and often entirely discouraged, by destroying the queen cells every nine or ten days, but this must be done carefully and not a single cell overlooked, or the bees will swarm just the same. Besides requiring much tedious work, and the desire of the bees is to swarm, and rebuilding cells throughout the greater part of the season, they do not work with the vigor they would if they were not discouraged in their efforts. These precautions only help to allay the swarming desire, and are effective only before the bees have gotten into the notion to swarm. Once they are determined to do so, it is a difficult matter to prevent it. The only proper remedy then is to satisfy their desire, not by allowing them to swarm according to their own sweet will, but by doing it for them.

The most successful plan generally resorted to, is "the brushed or shaken swarm" method, one that can be modified to suit local and particular conditions. Briefly, colonies that are found preparing to swarm, and with queen cells in the hives, are treated by shaking nearly all the bees off their combs as they are removed from the hive, and then placed in an empty hive, which is set on a new place, given a caged queen, or the remaining bees allowed to rear a new queen from several cells left on a comb that has not been shaken, and the inmates destroyed by the jars. There should be enough bees to properly protect and care for the brood, especially during cool weather. The combs removed are replaced in the old hive by frames containing full sheets of comb foundation. This change has the same effect upon the bees as if they had swarmed naturally. The bees will behave exactly like a swarm, and no colony of bees works with greater vim and vigor than a newly hived strarm. This treatment results in an increase in the number of colonies. If this is not desired, the number can easily be reduced after the swarming season by reuniting as many colonies as is necessary.

It should be understood that it is not necessary to treat each colony in the apiary as described. Only those that are actually preparing to swarm receive this treatment, and the number is not large if the 
proper precautions are taken to keep the colonies comfortable and contented so the desire to swarm is not awakened in them. In some seasons the desire to swarm is greater than in others, consequently more difficult to control.

A fact that should be remembered by, the beekeeper in his efforts toward swarm control, is that if swarming can be kept in check until the honey flow begins, all swarming preparations will come to an end. That a honey flow will put a quietus to the swarming desires of the bees is generally known among Texas beekeepers. Instead of continuing swarming preparations, they divert all their activities to gathering and storing honey, and, as a general rule, no more swarming may be feared.

This is entirely unlike the conditions in the North and East, where the opening of the honey flow brings with it wholesale swarming

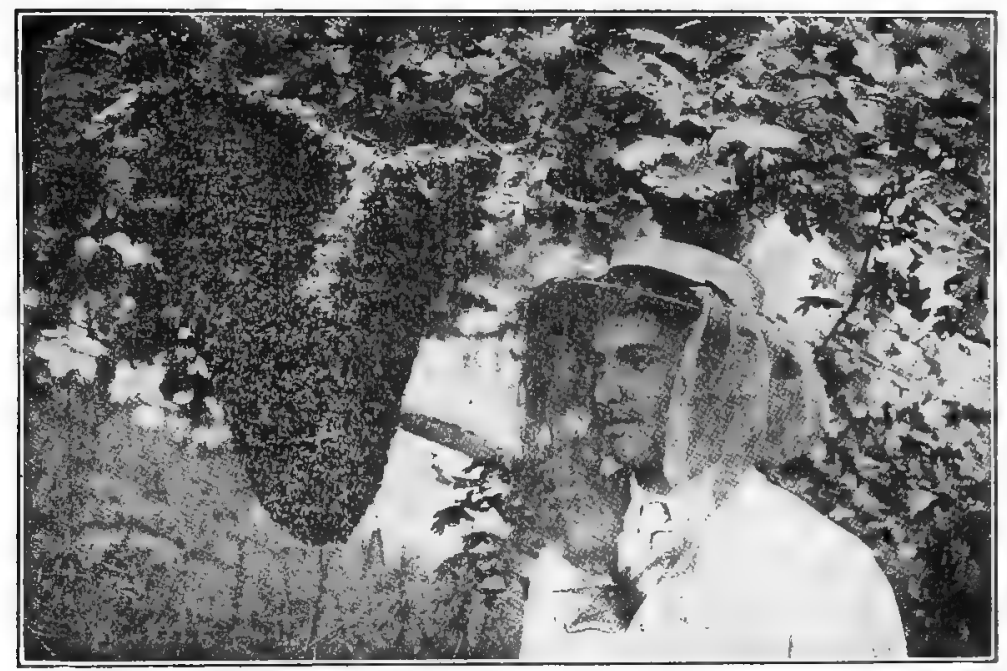

An ideal clustered swarm of bees.

that is more difficult to control and keep the forces in such a state that a paying crop of honey may be secured. It is by far an easier matter to control swarming before the honey flow comes, as exists in Texas, and where the bees cease swarming entirely upon the opening of the honey flow.

\section{PREVENTING AFTERSWARMS.}

After a first, or prime, swarm has issued, the old colony is left queenless, having, however, queen cells that will hatch in about eight days; or, if the first swarm has been delayed, in less time than that. It will take a longer time, of course, if queen cells were not already started, but in this case the queenless bees will proeeed to start these cells at once.

If the old colony is still strong in numbers, they may swarm again in nine days' time. Otherwise, only one queen will be allowed to 
hatch, and she immediately proceeds to tear a hole in the side of her rivals' cells and sting the inmates to death. After mating, she becomes fertile and takes up her duties in egg laying in due time, and the colony soon builds up to its normal strength again.

It is not wise to allow a colony to cast more than one-the first or prime swarm-and all after-swarms should be avoided. Each succeeding swarm will not only be weaker in numbers, but the hive from which these swarms issue will finally become a worthless, weak colony, that will not profit the beekeeper anything, and may succumb entirely.

After a colony has swarmed, all queen cells, except one of the largest, should be removed from the combs and the colony watched, to make sure that the queen from this emerges and becomes successfully mated. While this prevents immediate after-swarming, the colony with the new queen may soon be strong enough again to swarm with its new queen, if the desire to do so has not been given up. To thwart the bees in this, it is customary to leave the old hive near its old stand, on which the swarm now is, for a week or ten days. After this length of time, the old colony is moved to its new location in the apiary during the day, at which time most of the bees are flying. The flying bees will find their hive gone upon returning, and the apiarist, being sure to have the hive of the swarm nearest to the flying bees, these will join the swarm.

This method does not only prevent further swarming of the old colony, by weakening it in strength of bees, but since it is the swarm that will store the largest amount of surplus, the addition of the bees aids materially in this direction, as they are worth more, added to the swarm, than if left in the old colony.

\section{CLIPPING QUEENS' WINGS.}

It is aggravating to find swarms of bees clustering in almost inaccessable places, especially in the top of high trees. It is also disagreeable to lose swarms when nobody happens to be near the apiary. For this reason many beekeepers clip one or both wings of their queens to prevent them going with the swarms that may issue. This is a very simple operation. The queen is grasped carefully by the thorax with the thumb and forefinger of the left hand and lifted from the comb, and with a pair of small scissors in the right, part of a wing is easily clipped off. Exceeding care must be exercised, however, not to clip any of the queens' legs, which have a tendency to get in the way in her struggles to be released.

'The best time to clip queens' wings is in the early spring, as they are easily found in the hive before the colonies become very populous in numbers. Care must be taken not to clip the wings of a young virgin queen, as this well prevent her being mated and she will be worthless.

The practice of clipping queens' wings is increasing from year to year, not only because they can not then go off with a swarm, which is worth the time and trouble it takes to do it; but, for another reason as important, i. e., to keep a record of the queens and their ages as well. Beginning with clipping the right wings of all the queens of a certain year, the left wings of all queens the next year, and both 
wings in the third year, the age of each queen may be known at a glance. As the average life is three years, it is hardly necessary to have another manner of clipping for the fourth year, when all new queens are again elipped on the right wings. Any queens kept over three years may have another distinguishing clipping mark on one or the other wing, in addition to the regular manner of elipping each year.

It is an easy matter to handle a swarm with a clipped queen. Unable to go with the swarm, she will be found crawling on the ground in front of the hive from which it has issued. She may be caged, and after the old hive has been removed to one side and a new one with full sheets of foundation put in its place, the cage be laid in front of the entrance. The swarm may cluster or not, but it will soon discover that its queen is not with it, and immediately return to the old location and enter the new hive. As the bees do so the queen is released and enters with them, and thus the swarm hives itself, even if it had alighted in a tall tree or other inaccessable place.

However, there are some objections to clipping queens. If nobody is around to attend to the queen and to replacing the hives, the old queen may become lost, the bees rear a new queen, and swarm again as soon as she hatches, unless they have given it up. The queen, being a virgin, the swarm may not eluster but may go away at once if not hived in the usual way. If the old queen has found her way back to the old hive, the bees may not be satisfied upon their return and may swarm again and again, until they become weary, kill the old queen, and rear a new one, with the results stated. But it is possible to tell by outside appearances of a colony whether it has swarmed, and if, upon examination, this is found to be true, or queen cells are found, the colony may be divided, or shaken into a new hive, as soon as discovered.

It is a good policy to have all queens clipped, especially in distant out-yards only visited occassionally, as the loss of a clipped queen alone is not so serious as the loss sustained by an unclipped queen leaving with the bees of a swarm. The chances are that swarming with clipped queens can be thwarted in many instances and the bees saved.

\section{NATURAL OR ARTIFICIAL INCREASE.}

Ordinarily, bees increase fast enough for most persons by natural swarming, even upon keeping this within the limit of one good swarm to each colony inclined to swarm, as there are always some colonies that do not swarm. The desire of the experienced beekeeper is to prevent swarming, rather than to allow the bees to increase this way. If increase is desired, it is made artificially, by dividing strong colonies at a time, usually after the honey flows are over, when this will not interfere with honey storing. It is always advisable not to divide the colonies too often. Increase should be made slowly, and it is not wise to more than double the number of colonies in a season. The stronger in number of bees each division is, the better they will progress.

The most commonly used method is that of forming small colonies, or nuclei, by simply taking two or more combs of hatching brood, 
honey and adhering bees, and putting these into a new hive on a new stand. A ripe queen cell should be given, or, better, a laying queen, as it is not advisable to permit any but very strong colonies to rear queens. Besides, the nuclei will progress much more rapidly, as no time is lost waiting for a new queen to be reared.

A few bees shaken from three or four combs from any strong colony and placed in a hive supplied with two or three combs of hatching brood and honey, and provided with a queen, or ripe queen cell, will build up to a strong colony, if properly cared for. These little colonies should be helped from time to time by adding to each a comb of hatching brood and honey, or they may be helped by feeding them, if necessary. Properly handled, such nuclei will not only be strong enough for the winter, but may gather some honey before the season is over.

When conditions are favorable and there is ample time in which the colonies may be built up sufficiently for the honey harvest, all strong colonies may be divided equally and two colonies made of each one. One-half the combs, bees and brood are placed in a new hive. The remaining space is filled up with frames containing full sheets of foundation. The old hive with half the combs, bees and the queen are now moved to a new place in the apiary. The new hive is set on the old stand and may rear a new queen, or better, have one supplied to save loss of time.

One of the best forms of increase is that secured by shaking or "swarming" the bees artificially, as already described under "Swarm Prevention." In this way the number of strong colonies can be easily doubled. If only one-third increase in number is desired, most of the bees from two colonies standing close together may be shaken in front of a new hive, placed about midway between the two, and the old colonies removed to new stands.

\section{MAKING RAPID INCREASE.}

Bees may be rapidly increased by dividing each strong colony into a number of nuclei. This is accomplished by putting one comb of brood, honey and bees, together with a comb of honey taken from some other colonies, in each of as many hives as there are such combs to supply them with, thus allowing them to build up into strong colonies. If possible, a caged laying queen should be given to each division, except the one having the queen of the original colony, as this helps them to build up much more rapidly. Otherwise ripe queen cells should be given.

If such colonies are deprived of their queen a few days previous to the division, better results will be obtained, as queenless bees will remain, when placed on a new stand, much better.

One of the best methods for securing these results, and at the same time, excellent queen cells for making rapid increase, is to collect eight of the best combs of hatching brood from a number of strong colonies and place these in a ten frame hive, so that a space will be left between the combs in the center of the hive for another comb. This comb is supplied from one of the best colonies in the yard, from which queens are to be reared. It is previously prepared by placing 
an empty comb in this hive three days before the increase is to be made, so that it will be well supplied with eggs just ready to hatch, and of the right age, when placed in a queen cell building colony. The hive thus prepared is placed on a stand of a very strong colony, which latter is removed to a new stand. About a quart of bees from the strong colony is shaken in front of the newly prepared hive, care being taken not to shake the queen with them. These and the field bees will make a powerful nucleus to take care of the hatching brood, and, thus supplied with a vast number of newly hatching bees, the nucleus is in the best condition for the building of a large number of extra fine queen cells, in which the larvae are supplied with an abundance of royal jelly, produced in large quantity by the young nurse bees. This method is one of the best for producing large and valuable queens. If a still larger number of nuclei is wanted, a number of such colonies may be prepared. Just before the queen cells are ripe, or nearly ready to hatch, or about ten days from the time the nucleus was made, as many hives are prepared as there are combs containing honey and brood, and the entire nucleus is divided into nine nuclei, as already described. One of the best queen cells, carefully cut from the comb containing them, is placed on the side of each brood comb, in each nucleus, by pressing a hollow place with the finger and laying the queen cell so that its lower end will hang downward, or in the natural position, and a bent wire staple is stuck over the cell and through the comb on either side of it to hold it in position. The two combs are then pushed together as closely as possible and the nuclei carefully carried to the stands they are to occupy. Care should be taken to have about an equal share of bees in each of the nuclei, and nearly all the bees from the one remaining on the old stand may be placed in the nuelei to be taken away, as the bees that return will still leave the strongest nucleus on the old stand. The entrance to each nucleus hive should be tightly filled with green grass or weeds to prevent many of the old bees returning to the former location and at the same time to prevent robber bees from destroying the nucleus.

Another excellent way, especially when shallow supers àre used in addition to the brood nest so brood may be reared above, is to slip a queen excluder between the super and the brood nest of each strong colony that has a sufficient amount of brood in the super, taking care that the queen is below. About ten days later, when all the brood is sealed, these supers are simply lifted off and carried to the new location in the apiary, where a bottom board, to receive them, has already been placed on a stand. The entrances are then immediately closed, with green grass or weeds, to prevent the bees from returning to the old hive. At the same operation a ripe queen cell, or, better, a laying queen, is given to each of these nuclei, and they build up into prosperous colonies immediately. The secret of the method is in excluding the queen from the super so that there is mostly hatching brood and no young larvae to starve when the supers are removed. In this way, much increase can be made from time to time throughout the season, without materially depriving the old colony of its strength for storing honey. 


\section{QUEEN REARING.}

The simplest method of queen rearing is to select queen cells from colonies that are preparing to swarm, and place these in colonies, or nuclei, in which they may hatch and the young queens become mated. During the swarming season, many superior queens may be reared by selecting choice queen cells from colonies that have swarmed, and it is advisable for beginners to do this at that time.

Queen cells are built under two different conditions. When bees are preparing to either swarm or supersede their queen, cell cups are started and the queen deposits eggs in these. When bees are deprived of their queen and they are forced to rear another from the eggs or young larvae at hand, they are compelled to build the cells about the worker eggs, or larvae already in the cells, by tearing down the cell walls. Queens reared from supersedure cells are just as good as those from swarming cells, and it is possible to obtain a large number of choice cells from a colony by removing them promptly and forcing the bees to produce more cells in their effort to supersede their queen.

Various artificial methods are employed by which superior queen cells may be obtained. One of the best has already been described under the heading of "Making Rapid Increase." Eight combs of hatching brood and honey are placed in a ten frame hive and spaced apart somewhat wider in the center than regularly for a ninth comb with select eggs, from which the queen cells will be built out. The wider space permits a larger number of feeding nurse bees to cluster on the comb with the developing queen cells, and also allows freer removal of the comb without injury to the extending delicate queen cells.

An improvement in preparing the larvae for queen cell building is known as the "Alley Plan," in which the worker comb containing the eggs are cut into strips and attached to the lower edge of a comb, after a few inches of the lower part of it is cut away. From these the bees then construct the cells. The strips have a single row of e.lls containing eggs on one side, while the damaged cells on the other side are cut down to within one-eighth of an inch of their bottoms. This side of the strips is then dipped in melted wax and stuck on to the lower edge of the prepared comb, or upon bars, which are then fastened in a frame in such a way that the cells containing the eggs will hang downward. The egg in every alternate cell is destroyed by twisting a sulphur match into the base of the cell. This frame of prepared cells is given to bees which have been made queenless about six hours previously. The cells are started and completed in the queen rearing colony, and when ripe may be eut off and used wherever wanted. Some queen. rearers of experience place these cells in little nursery cages, a large number of which fit into a frame, and the young queens are allowed to emerge from the cells. From these cages the queens are introduced into nuclei. Virgin queens just emerged can be liberated in nuclei without being destroyed. After they are about five days old, however, tobacco smoke should be used in introducing them. 


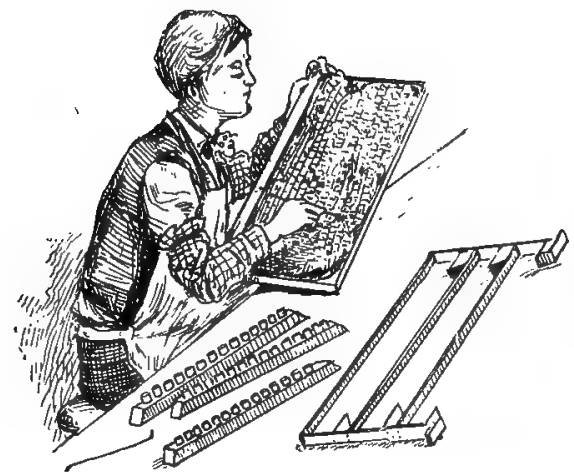

(1)

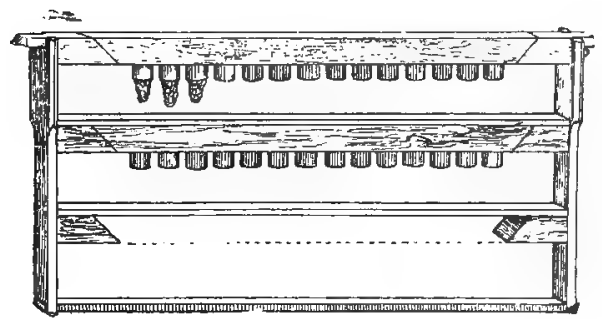

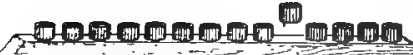

(3)

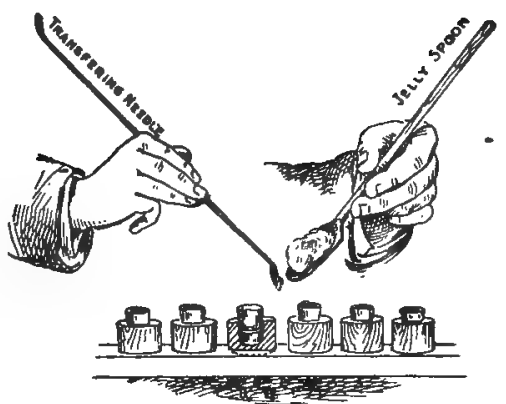

(2)

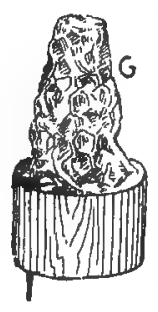

(4)

(1) Transferring the larvae. (2) Putting "royal jelly" in cell cups.

(3) Cell bars in frame. (4) Old ce!ls to be used again.

To allow easier handling and to lessen the possible injury of the queen cells, as is often the case when these are cut from the combs, "cell cups" are prepared by repeatedly dipping a moulding stick into melted wax. These cell cups are attached, with melted wax, not quite an inch apart, to a horizonta] bar that can be placed in a brood frame. A little "royal jelly," found in the bottoms of queen cells, is smeared in the bottom of the cups, and worker larvae just hatehing from the eggs are transferred by the aid of a toothpick, a quill or a special transferring spoon to the bottom of these cell cups. Thi : transferring must be done very carefully, however, so as not to injure the little larvac'. With some queen rearers, the placing of the royal jelly in the bottoms of the cells is deemed unnecessary, as there is no difference in the quality of the queens reared either way. The prepared frame is then hung in a colony preparing to swarm or to supersede its queen,

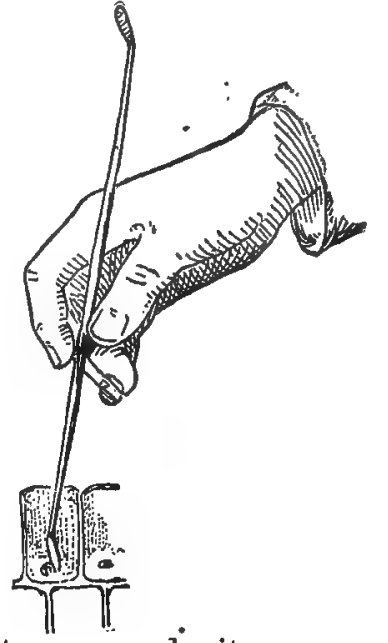


or in an upper story of a strong colony having a queen-excluding zine between it and the brood chamber, where they will be completed. Care must be used to remove the cells before any queen emerges, as the first one hatched will destroy all the rest of the cells.

- A still further improvement is that of using queen cell cups pressed by a machine upon flanged, cylindrical wooden cell cup blocks, which are attached to cell bars in such a way that they can be easily removed and interchanged. The cell cups are "grafted," as transferring the larvae to them is termed, and placed in the cell building colonies in the manner already described, and when the cells are completed they are used as desired. The nuclei used are of different sizes, ranging from a few combs in the standard hives to very small boxes containing little combs and only a mere handful of bees. It is impossible to go into details concerning other various employ-

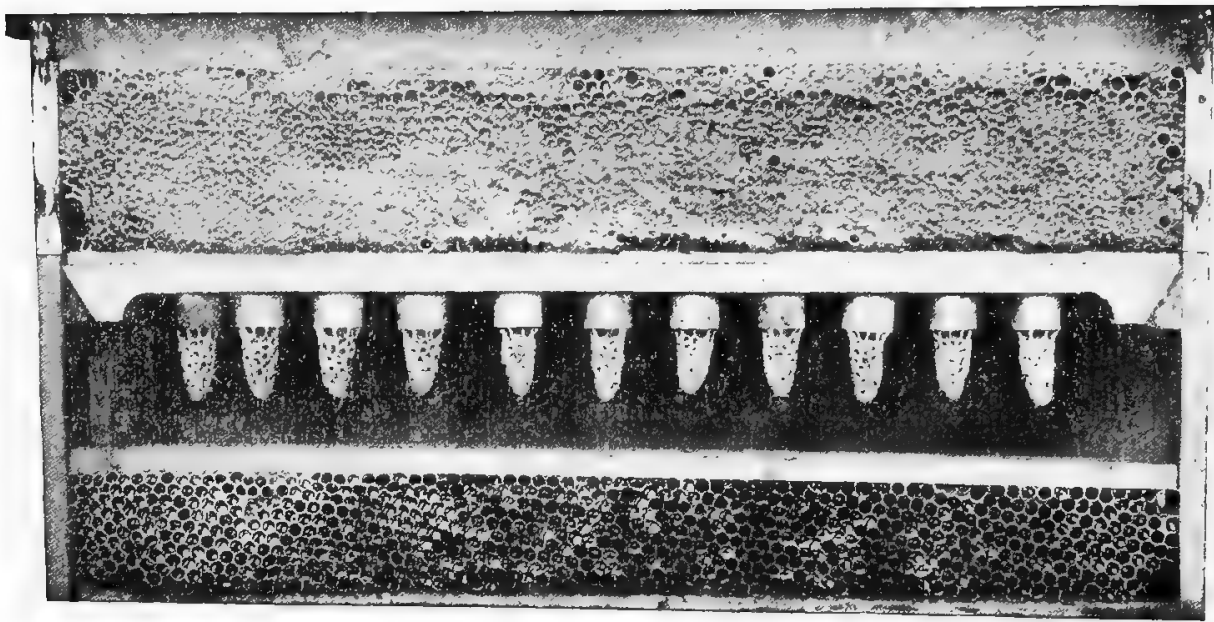

A fine lot of perfect queen cells.

ments and advantages here, however. Further information can be obtained out of books pertaining to the subject of queen rearing.

\section{IMPROVING BEES.}

There are hundreds of beekeepers who pay very little attention to the improvement of their stock, and the result is that their bees are not up to the average in prolificness and honey-gathering qualities. A few dollars spent in purchasing queens of any pure race is one of the best paying investments a beekeeper can make. Suppose the average yield of honey obtained by common stock is $\$ 2.00$ per colony and that, by spending a few dollars for only a half dozen untested queens from a reliable breeder, from which to rear young queens to replace the inferior ones in the colonies, the result would be the improvement in the stock would add only 50 cents in the way of increased.yield per colony-in other words, instead of each colony yielding $\$ 2.00$, the yield would be $\$ 2.50$ - the gain in one year would 
be quite an item, especially if many colonies were kept. Furthermore, the value of the stock would increase from year to year, and, if the improvement was continued, the gain in five or ten years would amount to quite a snug sum. It pays, therefore, to spend a little time in improving the stock of bees, and this should not be neglected as much as it is.

\section{RE-QUEENING.}

In most of the apiaries, whether consisting of only a few colonies or of a considerable number, there are always some colonies that far outstrip others in honey yield, while there are many that produce very little, and some almost no honey at all. This condition is one that costs the beekeeper considerable, in that the labor expended on those giving almost no returns is practically the same as upnn the good ones, and is one that will not be allowed by the wise beekeeper. Instead of wasting time with these inferior colonies, whose inefficiency is generally due to the kind of queens, they should be replaced by better stock.

The best time to do this is immediately upon the close of the honey season, as it is then that one is able to tell the colonies that have done the best work and those that have not come up to the mark. Another reason is that the prices of queens are lower at this time than for those reared earlier in the season; and a third reason is that the changing of queens at this time can be done without interfering with the honey crop. All colonies should be re-queened as soon as they are found to have inferior queens, no matter at what time of the year.

There are various ways of re-queening colonies. In case the beekeeper has not the time to rear his own queens, purchasing untested queens by the dozen, if a large number are required, will make the investment a slight one, as compared with the improvement of his stock and the better and larger yields of honey that will be received in return. Even the small beekeeper with only a few colonies will do well to buy queens with which to replace the inferior ones he may have. The beekeeper who has time to rear his own queens can have ready by this time young laying queens, to be introduced in the regular manner, after the inferior ones are removed.

Another method practiced is that of placing a hatching queen cell in the super of each of the colonies to be re-queened, and paying no attention to the inferior queen below. This method is the most practicable one, if carried out on an extensive scale, as the young queen hatching above will find her way into the brood nest below and the chances are that the young virgin will kill the old queen. This saves much valuable time to the beekeeper, which would otherwise be consumed in hunting up the old queens, especially in strong colonies. No matter what method of procedure is adopted, re-queening all colonies that are not doing well on account of inferior queens should be counted as a paying investment. 


\section{KIND OF QUEENS TO BUY.}

It is often a question with some beekeepers as to what kind of queens to purchase, with which to improve bees. Various beekeepers give as much as $\$ 5.00$ apiece for breeding queens from which to rear other queens or for re-queening old colonies. Thus, the total expenditure for half a dozen such queens would amount to $\$ 30.00$, and, while this method is a good one, since the young queens reared from these will be better than the old stock, the chances are that they will all produce hybrid bees, owing to the fact that they will mate with drones of the common stock in the apiaries. A more economical way, and one that results in a larger number of purely mated queens, is to spend the same amount of money, or $\$ 30.00$, for untested queens from a reliable queen breeder, who is known for producing good stock. The chances are that a good number of the queens thus obtained will prove as valuable as the $\$ 5.00$ queens, while others may be worth from two to three dollars, and probably range in value down to the price of untested queens. Since untested queens from reliable breeders can be purchased at from 75 cents to $\$ 1.00$ each, and cheaper in larger quantities, this is by far the most satisfactory way of buying queens when improving the stock in an apiary. Thereafter, many of these queens may be used to rear daughters from, and since there will be a large number of pure drones, the chances of becoming purely mated are better than if the high priced queens were purchased.

\section{REARING OR BUYING QUEENS.}

Queen rearing is really a separate branch of beekeeping. Few beekeepers produce honey extensively and rear queens for the market at the same time, and the number is decreasing in this day of specialization. The successful queen-rearer devotes his entire time and attention exclusively to this part of beekeeping. Procuring a crop of honey is a secondary matter with him. However. it pays even extensive honey producers, and especially amateurs, or those who have a small number of colonies, to rear queens at times.

It is an open question whether it is better for honey producers to buy queens, or to rear them. While a large number rear their own queens, it is doubtful whether or not larger producers, who devote their entire time to honey production, would not do better to buy them. After trying both ways, some extensive honey producers have found that it does not pay to rear their own queens, and that the specialist in queen-rearing is better prepared to furnish good queens in large numbers, at less expense.

The beginner, with only a few colonies, would do well to buy the few queens needed in case of a missing queen in one of his colonies, or for the number of increase to be made, until he has learned to rear good queens. While this plan seems a little more expensive, he has the advantage of so improving his stock that it will produce more than the cost of his investment, while his own reared inferior queens may reduce his honey crops materially. It is not meant that rearing one's own queens is to he discouraged, because one who has the time 
and abiltiy to rear good queens is enabled to make just that much more profit in beekeeping. By always breeding from the best stock, the erop of honey may be increased to such an extent that it will pay many times over the extra cost of rearing queens, and one is not required to order good stock from various queen rearers who may not send out any better stock than those reared at home. However, this can be prevented by a little investigation as to the reliability of the queen rearer from whom it is contemplated to order queens, with the result that nothing but extra good stock will be secured. Queen rearers of established reputation can be found who are prepared to produce large numbers of superior queens at a much lower price than the beekeeper, who has all he can do to attend to his bees in the production of honey; and if queens are purchased in large numbers, they can be obtained at a very low price.

If the beekeeper is favorably situated to do so, rearing his own queens is a point in his favor, provided he has the time to devote to it. In many instances, however, the location is not such as to permit the rearing of good queens, without interfering with the honey crop, while the location may be unsurpassed for producing extensive crops of honey.

Every beekeeper should, however, acquaint himself with the rearing of queens, so as to be prepared in case of an emergency. Wherever it is possible to do so without loss, queens should be reared at home. If this is not the fact, it would be best to purchase them. Queens may be obtained at almost any time of the year from a large number of queen rearers whose advertisements appear in bee journals.

\section{INTRODUCING QUEENS.}

Colonies of common bees, bought in either frame hives or in boxes and then transferred into frame hives, can be improved by introducing a queen of a good strain of Italian or other pure race of bees by simply hunting out and destroying the common queen and giving the new queen to the colony. The colony having an inferior or aged queen may be improved by introducing a new queen after removing the old one, and any colony that has become queenless by the loss of. its queen may be made "queen right" in the same way.

It must be remembered, though, that if the queen of a colony is removed and a strange queen put in her place, the bees will promptly seize the intruder and sting her to death or "ball" her until she is dead. In balling, they crowd into a large cluster and squeeze together with such force that the death of the queen follows. Instead of liberating the queen into the hive, she should be placed in a small cage provided with sereen wire cloth on one side and having a passage-way in one end filled with "queen cage candy." The bees will remove this candy, which takes from three to four days. By the time the passage is cleared, the queen has not only acquired the same scent as that of the colony, but the bees of the colony realize their queenless condition, and she is permitted to march out of the cage unmolested and takes up her egg-laying duties almost immed!ately. There are various styles of queen-introducing cages, but they all work on the same principle. The mailing cages, in which the 
queens are received from the queen rearers, have the candy passage arranged iu such a way that the bees will liberate the queen in the proper length of time. These are usually provided with a small

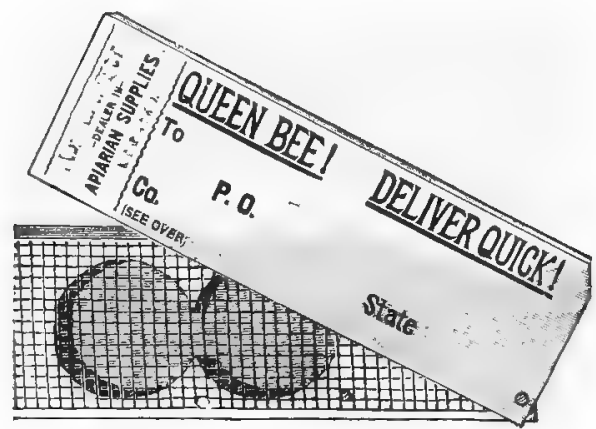

piece of perforated cardboard over the candy hole in one end of the cage, to extend long enough the time required by the bees to clear the passage-way. The queen would be destroyed if sle were freed too soon.

Valuable and high-priced queens should be placed on a comb with very young bees and hatching brood inside of a screen wire cage into which the frame containing this comb fits and is fastened so no bees can find access to it. This is then hung in the center of a queenless colony after two combs have been ramoved from the hive, and left for $a$ week or ten days, when the comb with the queen can be removed from the screen wire cage and gently placed back in the hive.

Another way is to fold a piece of screen wire cloth into the shape of a shallow box about three-fourths of an inch deep and three or four inches square. The screen wire is cut about an inch larger than the box is to be deep, then pieces are cut out of each corner one and one-half inches square. Next the wire threads are removed from the outside edge of all four sides half of their distance. Then the sides are bent down square, forming the box with the ends of the wires protruding so they may be stuck through the comb. The queen is now placed upon the comb where young bees are hatching, and the cage placed over her and pressed firmly into the comb. No old bees can get to the queen, and the young hatching bees will care for her properly until she is released in a week or so.

Another way is to place a screen wire cloth over the top of a colony of bees that has been made queenless, and set on top of this another hive. In this is placed a comb containing many young and hatching bees and some honey, or an extra comb of honey may be placed hy the side of it, which is preferable, and the queen is released upon the brood comb. Later she may be removed into the lower chamber, or a colony may be formed in the top hive by putting combs of brood into it from time to time and then removing the top story all together.

\section{TEXAS DIVIDED APICULTURALLY.}

On account of the large area of Texas and the variations in soils, altitudes and climatic conditions, and consequent differences in flora met with over its surface, there are distinctive main sources for surplus honey in different sections of the State. For convenience, Texas may be divided into six different parts apiculturally, viz: North, central, east, south, west, and southwest Texas. Each of these regions 
will be described further under the next subject, "Main Honey Sources."

Numerous inquiries are every year received in regard to suitable locations for beekeeping. A sufficient answer is, that it is impossible to suggest, in print, a specific spot that would be best, on account of the fact that the State is such a large one and the localities so varied. Besides this, locations are being constantly taken up by beekeepers. It is hoped that statements contained in the next chapter will serve the purpose of imparting such information as is generally desired concerning the apieultural value of the various sections of Texas. More definite knowledge can be obtained through correspondence with beekeepers located in the several sections, or, better still, by, personal investigation. It is advisable that the beekeeper, desiring a new location, make a personal visit before moving to a new place. Persons from a distance should take advantage of the many "home seekers" excursions offered by the railroads. If satisfied with a new location, after looking over the ground thoroughly, a final move can safely be made. Under no circumstances should "stakes be pulled up at home," especially if the old place is a fair one for beekeeping, or an immediate move made to a new location without due consideration. It should be remembered that climatic and other conditions, as well as various advantages, may not be as favorable in a new location. This is given as a warning note to guard against beekeepers giving up a good location where the are able to make their pursuit profitable, for a new one with which they may be quite disoppointed.

\section{MAIN HONEY SOURCES.}

Beginning with North Texas, which includes the Panhandle country, beekeeping is not prominent except in a few favorable localities. The greater part of this division is level plains country where stock raising, wheat growing and other agricultural pursuits are followed. Its vast, level topography and the lack of honey yielding flora, with severe cold weather in winter and extreme hot and dry summers at times, make it, as a whole, not well suited to beekeeping. However, there are some localities in the eastern part of this section, especially along the Red River and adjacent valleys, that are well adapted to beekeeping.

The mesquite tree (Prosopis) areas extend into the southern part of this North Texas division, and in some places, where cotton yields honey in connection with it, bees may be kept profitably. Horsemint (Monarda) and cotton are the main sources in the eastern portion, and in a few places are supplemented by sweet clover (Mellilotus), which is abundant in some places where it was planted previously. Other minor honey and pollen yielding plants help in the building up of the colonies.

Just below this, Central Texas occupies the middle portion of the State. It covers the main black land agricultural distriets with intervening high ridge lands and smaller valleys. Horsemint and mesquite are here the two most prominent natural sources, and cotton homey is produced abundantly. In addition to a vast number of 
minor plants throughout the spring and summer, sumach (Rhus) and broom-weed (Guttierezia) produce honey in the fall. There are some excellent localities in Central Texas, especially where horsemint, mesquite and cotton can be depended upon in the same locality. During favorable seasons, one of these three main sources will insure a profitable crop. However, it is wise to locate where more than one source can be depended on in case one of them fails.

East Texas has few large honey plants, but a good many small ones. Fruit growing is of great importance in this part of the State. The orchards, covering thousands of acres, not only make it profitable to keep bees in small numbers for honey production, but for pollenizing fruit blossoms, for which their services are absolutely necessary. In the southern portion of East Texas, bass-wood (Tilia) prevails in the forest districts and yields an abundance of light colored honey. During a favorable season the vield is so great that the bees are unable to store it. The flow is very rapid and of rather short duration. Holly (Ilex), Chinquapin (Castanea) and other bloomers help out during the season.

In South Texas, which prartically includes the lower coast country east of the Guadalupe River valley, beekeeping is not so profitabl'. The rattan vine (Berchrmia) is very abundant, together with other honey yielding vines and plants in some parts, especially in the low places and along the water courses. The honey is dark in color as a rule, although of good flavor. Most of it is shipped in barrels to large bakeries. In a few favored locations bees do well, but immense stretches of low lands are without suitable flora for beekeeping.

West Texas resembles the western part of North Texas, on account of its close proximity thereto. Its level prairies are, however, checkered by river canyons, along which the natural honey rielding flora is abundant, especially in the southern portion, which extends in a rough line to that section traversed by the Southern Pacific railway, which will be used, for convenience, as a southern boundary of West Texas. In the agricultural districts, alfalfa (Hedicago) is reported a main honey source where it is abundantly grown. There are large areas of mesquite, cats-claw (Acacia) and other honey yielders in abundance in and adjacent to the canyons. There are many places not suitable to beekeeping, however; especially in those sections where rainfall is deficient and drouths are long and severe.

Southwest Texas can well be considered the most important section for beekeeping, as honey yielding flora is here most abundant. Although a semi-arid region, there are numerous honey-yielding plants and trees, mostly of shrub-like nature. Among these is the mesquite (Prosopis), which covers the prairies. This yields in favorable years great stores of honey of a very light amber color and of good flavor. There are two distinct and separate, and sometimes three, blooming periods in each year. The first occurs in early April, earlier or later according to the season. This lasts for several weeks. In it pods, or "beans," are formed, so that ripe and immature beans are on the trees when the second blooming period opens in June and July. As a regular yielder this source can be depended upon. The most important source in Soutnwest Texas, however, is the "huajilla" brush, pronounced, "wa-he-ah" (Acacia berlandiera 
Benth.) It blooms in April and yields nectar, for a period of about two weeks, in such abundance that it is impossible for the bees to gather it in favorable seasons. It is perhaps the most light colored and mild flavored honey produced in the State; has a most delieate aroma, and has become famous for its excellent quality. "Catsclaw" abounds in this portion of the State and produces excellent honey very early in the season. Mesquite, "huajilla" and "catsclaw" are the three main sources in Southwest Texas. "Cats-claw" blooms so early in some years that late cold weather sometimes cuts off this source to some extent, if not all together.

Besides these main honey yielders, there are scores of other more or less important honey-yielding and pollen-producing plants and shrubs, as well as trees, that provide more or less forage for the bees almost throughout the year. The main honey flows in this part of the State, however, come during the spring months and are of short duration, but the nectar is produced in such abundance that enormous crops are obtained.

\section{OTHER HONEY PLANTS.}

From the author's extensive collection of about four hundred species of Texas honey-yielding plants, the following is a list of some that are more or less worthy of remark and not already mentioned.

The earliest bloomer, important for early brood-rearing, is the mistletoe (Phoradendron), a parasite on most of our hard-wood trees. It yields pollen, and some honey, in December and January. Tripleleafed barberry (Berberis) is a bush that blooms next in importance for brood-rearing, yielding immense quantities of pollen in January, February and sometimes as late as March. Then fruit-bloom begins with the plums (Prunus), of which there are many species, both wild and cultivated, followed by pears, peaches and other fruits for several months in succession. In February and March the oaks (Quercus), of many species, also yield much pollen. The willows (Salix), and the elms (Ulmus), aid much in stimulating brood-rearing. Hoarhound (Marubium) begins blooming in February, and lasts until summer. This yields an amber honey of a rather nauseating flavor, but which is lost in time. As it is generally mixed with mild honey from other sources, no serious complaint is made against it.

The trees belonging to the hickory family (Hicoria), to which the pecan and hickory nut belong, and also the walnut (Juglans), yield pollen and some honey; also the cottonwood-trees (Populus). These are followed in March and April by a carpet over the entire open country and prairies of our State flower, commonly known as "blue-bonnet," the blue lupine (Lupinus subcarnosus), which yields pollen of various colors, from the palest yellow to the deepest red and orange. Redbud (Cercis), otherwise known as Judas-tree, is another stimulator early in the season.

Along regions where light, stony and adobe uplands prevail, what is known as rock-brush (Eysenharditia), yields an abundance of excellent honey in April and May. Several species of holly (Ilex), also bloom during this time. Two species of persimmons (Diospyros), are very common in Texas, and yield much honey, especially the black 
Texas persimmon of the western part of the State, while the yellow kind is common in East Texas. Several species of crotons (Croton), in May and June, yield pollen. These are found in most parts of the State, and furnish some pollen even during severe drouths.

The cacti (Opuntia), of which the large kind, with its thick, fleshy, green, and pear-shaped leaf-like stems, known as "prickly-pear," is most common, sometimes yield much honey, and are great pollen yielders nearly every season. The honey is not considered good for surplus as it is astringent in character and strong in flavor; but it is valuable for sustaining the colonies during the early summer when very little else is in bloom.

A rich golden honey is produced by a small plant known as "marigold" (Gailliardia), which often covers the prairies in May and June. The flavor of this honey is rather marked. The vast fields of Indian corn and sorghum are much visited by the bees during their bloom in May and June, and these yield immense quantities of pollen. Of some importance both for pollen and honey are also the melons, and all of the members belonging to the gourd family (Cucurbitacea). Lippia ligustrina, known as "white brush," is most common and abundant in Southwest Texas. It is a very frequent bloomer during the season, depending upon the abundance of rain, and is so fragrant that the whole adjoining country is parfumed with its odor.

In East Texas abounds the bitter-weed (Helenium), which begins to bloom in June, and lasts until frost. This plant is not affected to any great extent by drouth, and blooms very regularly every season. Bees rarely work on it, except during such a dry season when there is nothing else, and then the bright colored honey is so bitter that it can not be eaten. The comb built during such a flow is of a characteristic bright yellow. A yield from this source alone is obtained only occasionally, hence it need not be feared. Blended with mild flavored honey from other sources its quality is not too bad to be used.

Another common weed is the ragweed (Ambrosia), of which there are several species. This is much like the croton in distribution, and yields pollen.

A valuable fall bloomer in most parts of the State is the broom weed (Guttierezia), beginning to bloom in August and continuing until frost. The honey is amber in color, strong flavored, but is most excellent for winter stores, and the colonies build up on it for the winter in splendid condition. This plant is sometimes not so abundant during a dry season, but comes quite regularly year after year. Where abundant, much fall honey is obtained from Virginian crownbeard (Verbesina), often called "wild tobacco." It blooms in October, but the dry summers cause a stunted growth of the flowers in many seasons, when it yields only sparingly.

While these follow in the order of their respective blooming periods, it must not be understood that all of them exist over the entire State, or in any one locality. While some of them have a very wide distribution, others are restricted to the particular habitat over a comparatively very small area. It is impossible, in limited space, to give a more comprehensive list with the distribution of the various 
honey-yielders than is presented here and in various places in the foregoing chapters.

PLANTING FOR HONEY.

This subject has been discussed for many years, not only among beekeepers, but others. Almost every beekeeper has heard some person ask: "What do you plant for your bees?" Here in Texas, practically the entire dependence is upon indigenous flora, or cultivated honey-yielding plants raised for other purposes. It has been determined that it will not pay to grow crops for honey alone, but that it is profitable to produce them if they ean be used for other purposes as well as honey-yield, for instance, sweet clover and alfalfa in regions where they do well. There are few valuable trees that may be planted to aid in the honey yield, which would do well under Texas conditions when planted for shade or ornamental purposes. Seeds from some valuable honey producing plants and shrubs may be scattered in waste places in some instances, but growing plants on valuable land for their honey-yield alone will not be found to pay. Forage crops that produce nectar may be planted and grown to advantage.

\section{BEES AND ALFALFA.}

Since alfalfa, grown in some western States so extensively, yields nectar to such an extent that hundreds of carloads of alfalfa honey are annually produced, and since the western part of Texas is in such close proximity to these States and has very similar climatic conditions, it would appear that as this part of the State is developed and put under irrigation large areas will be devoted to alfalfa fields, and apiaries be established to utilize the nectar. A study of the subject developed, that, while alfalfa does yield nectar abundantly in certain locations at times, it fails to yield altogether during some seasons without any apparent reason. Some years the most productive alfalfa fields with a profusion of bloom are not visited by the bees, which indicates that no nectar is yielded. This observation does not refer to the western part of the State alone, but to other parts as well. Bees have been found abundantly upon alfalfa blossoms on land of various conditions in northern, central and southern parts of the State, and on.high, dryer land alfalfa farms, as well as those of rich alluvial river bottom soils and, after several years of observation, it was found that during the majority of the blooming seasons the fields were not visited. There are some locations in western Texas where alfalfa honey is produced almost every year, but to what extent is not positively known. It is a subject that should be given further attention in the way of thorough investigation, since it is an important one. If, with the advent of large areas put under irrigation and the planting of alfalfa the production of alfalfa honey follows, it would mean a great deal to the honey producing industry of the State.

\section{BUCKWHEAT AS A HONEY PLANT.}

It is generally supposed that buckwheat honey is "something fine." This is probably due to every one having heard the old saying, "buck- 
wheat cakes and honey." Such cakes with good honey do, indeed, make one's mouth water; but not when "buckwheat honey" is employed. Buckwheat honey is dark and strong and has a peculiar twang. These peculiarities prevent its having a place on our Texas markets. Few people like it, though some are said to acquire a taste for it by continued use. Furthermore, generally speaking, buckwheat does not do well in Texas. Planting it is not advised.

In some parts of the State where the seasons are more favorable it may be utilized to tide the bees over a dearth of nectar from natural sources, by making successive plantings, one month apart, to obtain a succession of bloom for several months in early summer before the dry season, which is detrimental to its development. The seeds are planted best drilled in rows just as cotton is planted, and should be cultivated to produce a better growth of the plants. Sown broad-cast, it does not grow so luxuriantly and soon seeds and dies down.

\section{WHITE AND YELLOW SWEET CLOVER.}

As a general rule none of the clovers thrive well in this State except the sweet clover:-white clover (Melilotus alba) and yellow sweet clover (M. officinalis). Seasons over most of the State are too dry for the white clover, from which the greater part of the honey of the Northeast is produced. There are a few localities in the South Texas coast country, however, where this grows well.

In many places in Texas there are periods during which there is no bloom from which the bees can obtain even enough honey for the sustenance of their colonies. These dearths between honcy flows from natural sources, are sometimes very long ones. In some localities they occur between the spring and fall flows, and are very serious, as the bees sometimes starve during their continuance, unless fed. Feeding bees at these times is objectionable, because it incites robbing and stimulates the bees to unnecessary brood rearing, besides using up a large quantity of food. In such cases planting of sweet clover beforehand to tide the bees over might bring good results, as the clover, if it thrives, will come into bloom and yield nectar during the time. There is great variation in the length of these dearths in various localities, beginning and ending soon in some and late in others. In many places the gaps may be filled in entirely by the blooming period of sweet clover, which begins about June 1st in most localities and a little earlier in other and more protected situations, and depending, also, upon weather conditions. The yellow variety begins to bloom several weeks earlier than the white sweet clover and should be chosen for localitics where the dearth begins earlier in the season. Either variety, however, would cover the period of the average dearth, as the melilotus blooms very well in favorable seasons, when planted in localities favorable to its growth. In situations not so favorable, and during dry seasons, the blooming period is shortened considerably. However, it generally extends through June, July and August.

Sweet clover grows well after it is started, and waste places, found in the poorest soils, can be planted with this forage crop for the bees. There are thousands of acres of such waste land that could be made 
to grow sweet clover in the place of weeds. Our fence rows would be worth thousands of dollars if sweet clover grew where weeds of no use whatever now disport themselves. Especially would the clover

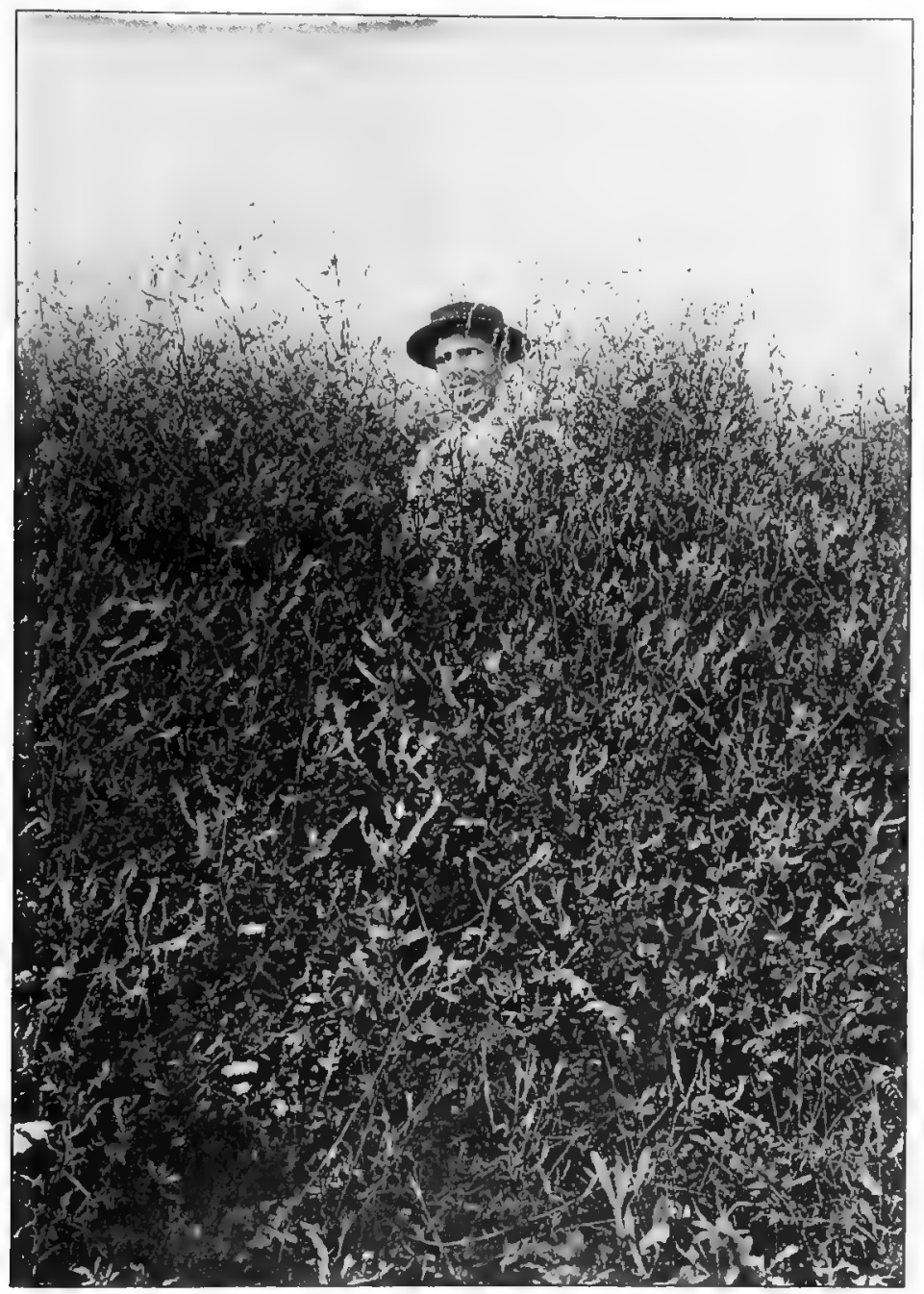

A luxuriant growth of sweet clover.

be valuable where a nectar yield would be produced just at a time when there was nothing else in bloom.

It was once feared that sweet clover was a noxious weed that spread rapidly and was hard to kill out of a field. This apprehension has been proven to be baseless, since a single plowing will kill the clover. and there is no danger of its spreading out of its bounds. It grows well in the northeastern part of the State, where it has become abundant in various places. It needs little attention in localities where the 
atmospheric and soil conditions are not too dry. In the dry parts of the State (West and Southwest Texas) it is hardly advisable to plant sweet clover, except in some of the low and fertile valleys and along streams. It has been found that it grows luxuriantly when drilled in rows and cultivated, but it would hardly pay to do this as a forage crop, as its growth is large and coarse.

The seed should be obtained in the fall of the year and scattered in waste places and along fence rows and rains will beat it in. It does best in places where grass and weeds do not crowd the little plants out. When once started it re-seeds itself. Being a perennial, it does not bloom until its second season's growth.

Sweet clover honey is of good quality, light in color and of very good flavor. The bees work industriously on the blooms from early until late.

\section{COTTON VERY IMPORTANT.}

It has been only a comparatively few years since cotton has come into prominence as a valuable honey yielding plant. Previous to that time cotton honey was hardly known. This was due perhaps to the fact that the honey obtained from the cotton plant was attributed to some other source. Of later years cotton has come to be known as one of the very best honey yielding plants. Especially is this true where it is grown on rich lands in valleys and river bottoms, where the growth is a luxuriant one. It gives largest yields under warm, damp atmospheric conditions. On poor soil and sandy land it does not yield nectar plentifully, and in some sections, or under certain weather conditions, not at all. In the average season a good yield may be expected from cotton in the black land districts and the river valleys. In favorable conditions it is not excelled by any other nectar yielder in the cotton growing belt.

The nectar is not produced inside of the cotton blossoms as in other flowers. The nectaries are located under the bracts next to the stem of the blossom, from which the nectar is secreted. There are other nectaries located on the underside of the leaves, one on each of the three main ribs of the leaf. The nectaries can easily be located as small low identations on both blossoms and the leaves. There are three underneath each blossom, and those located on the ribs of the leaves are situated about one-third of the length from the main stem of the leaf. At the proper maturity of both blossoms and young leaves, the nectar may be easily seen in a large drop in each nectary, and is easily gathered by the bees. During farorable conditions it is not necessary for the buds or "squares," as these are called, on the cotton plant, to develop into full bloom, but nectar secretion begins before the blossoms open.

The yield is most abundant in the early morning and decreases as the atmosphere becomes dryer toward the middle of the day. In the afternoon, unless the atmospheric conditions are very dry and hot, the nectar flow begins to increase again. During cloudy days, or when the atmosphere is damp, the yield continues abundantly throughout the entire day. The yield is most plentiful in locations where the cotton makes the most luxuriant growth and, in conjunction therewith, the most favorable atmospheric conditions prevail. It is 
often that single colonies store a hundred pounds, or more, of cotton honey during a favorable season. However, the average yield per colony of cotton honey deponds largely upon the soil conditions and the favorableness of the season toward the cotton growth, together with the atmospheric conditions existing during the honey yielding period, since all of these factors have an important bearing in the matter of a good yield. The lack of any of them decreases the average production of the colonies. There are many factors that must be considered as it does not yield nectar in all localities and under all climatic, as well as atmospheric, conditions.

Cotton honey is very light in color and mild in flavor when thoroughly ripened, and it compares well with the very best grades of honey. When gathered from upland cotton, or that grown on poorer soils, it has a slight amber color. When first gathered, the flavor is very characteristic of the juices of the cotton plant, but changes entirely as the honey ripens. During a heavy flow from this source there is a strong scent in the apiary like that of bruised cotton leaves, produced by the evaporation of the nectar in the hives. This is so pronounced that it has a sickening effect upon some persons who visit the apiary at such a time.

Ordinarily cotton honey granulates easily, and in the granulated form it is almost pure white and very fine grained.

The cotton honey flow ordinarily begins about July 1st and continues until frost, except when the fall of the year is a very dry one that causes the cotton to stop growing and producing squares, blossoms and the growth of young leaves that yield nectar.

\section{DISEASES AND ENEMIES.}

Bees are subject to the attacks of a number of diseases and enemies, like other forms of organized life, an for this reason it is necessary to possess a thorough knowledge of their care in successful beekeeping. The lack of this knowledge on the part of slovenly and indifferent beekeepers is a hindrance that makes them unsuccessful in the bee business, and aids in weeding out this class of persons who would only be a detriment to their provident neighbors in case of an outbreak of disease. Most of the enemies of bees are easily dealt with, and need not be feared by the average intelligent beekeeper. With the diseases it is different, as these are a great menace to the industry. The destructive diseases are of a contagious nature and, if not diseovered in time, may result in the infection of an entire apiary to such an extent that the losses therefrom may be heavy before the proper treatment can be given. It is important, therefore, that every beekeeper, whether engaged in the business on a small scale or extensively, should make a thorough study of the various diseases and malailies affecting honey bees, so that he may thoroughly prepare to care for any infection or outbreak at the very first moment it makes its appearance, and prevent wholesale infection and probable destruction of his colonies.

It is a mistake on the part of the beginner, as well as the advanced beekeeper, to think that it will be time enough to read up on the subject of foul brood when the disease appears in his locality or in his 
own apiary. It is of first importance that one be informed in advance and ready to identify such diseases, before any great harm is done. A disease may make its appearance suddenly and without warning, and unless the apiarist is thoroughly prepared to detect and combat it, there is danger of its spreading throughout the entire apiary before it is perceived and proper methods employed for its control.

After an outbreak of a contagious disease in a locality the danser of further spreading to other apiaries can only be eliminated by complete eradication. There are many persons keeping bees who do not know how, or do not care, to take the trouble to treat their bees. Such ignorance, or negligence, is often the cause of infection of the bees of careful apiarists in the locality and makes possible and probable the reappearance of the disease in his hives in spite of his constant efforts to prevent it. For this reason, inspection by properly empowered public officials is the only means of completely eradicating such contagious diseases. To accomplish this, Texas, as well as a number of other States, has a law prohibiting the keeping of diseased colonies, the selling or removal of any infected bees or apparatus, and controlling the shipping out of, and into, various localities diseased bees without proper inspection. The law provides that the State Entomologist shall be State inspector of bees. In order that the inspection work may be properly done, deputy or county inspectors are appointed by the State Inspector. They have authority to enter any place where bees are kept and examine such hives of bees and apparatus as may be necessary. In case of diseased apiaries, they are authorized to prescribe treatment, or, if necessary, to order the total destruction of colonies in which disease is too far advanced to warrant treatment.

Many persons are inclined to look upon such an inspection law as a necessary evil, but this is far from being true if it is enforced in the proper manner. On the contrary, it is an unmixid blessing and all should heartily assist in rendering it effective by promptly reporting and co-operating in the eradication of diseases that appear in their localities, and thereby make beekeeping more safe and certainly profitable.

\section{FOUL BROOD.}

Two kinds of contagious diseases of the brood of bees come under this head. The first, crnerally known as "foul brood," is perhaps the only one in Texas up to the present time.

American Foul Brood. This is a disease much dreaded and is caused by a specific germ that affects the larvae and pupae in the cells. It does not, as a rule, kill the immature bee until it has reached the pupal stage. The disease propagates and thrives in the tissues of the immature bers, and when first attacked, they turn to a light coffee color and later to a dark chocolate brown. The larvae sink down in a decaying mass to the lower side of the cells and give off an offensive odor, similar to that from an old glue pot, which, if once smelt, will never be forgotten. This is one way of detecting the presence of the disease in case dead larvae are found in brood combs, but. the most certain method of detection is by inserting a toothpick, or 
something similar, into the mass and then withdrawing the same slowly. If the disease is foul brood the mass will adhere to the toothpick and string out, or "rope," for about one-half inch or longer. These rotten masses are repulsive to the bees and, therefore, they do not remove them. Often the disease is discovered by the brood combs being irregularly capped after the disease has existed for some time, and many of the cappings are sunken and perforated. By this time much of the dead brood has flattened down on the lower side of the cells, often leaving the tongue of the pupae sticking upward and sometimes attached to the upper cell walls. When these have dried down to scales on the lower cell walls, which can not be removed by the bees, they are often difficult to see. The proper way of detecting them is to hold the comb so that the light, coming over the observer's shoulder, strikes the lower walls of the cells.

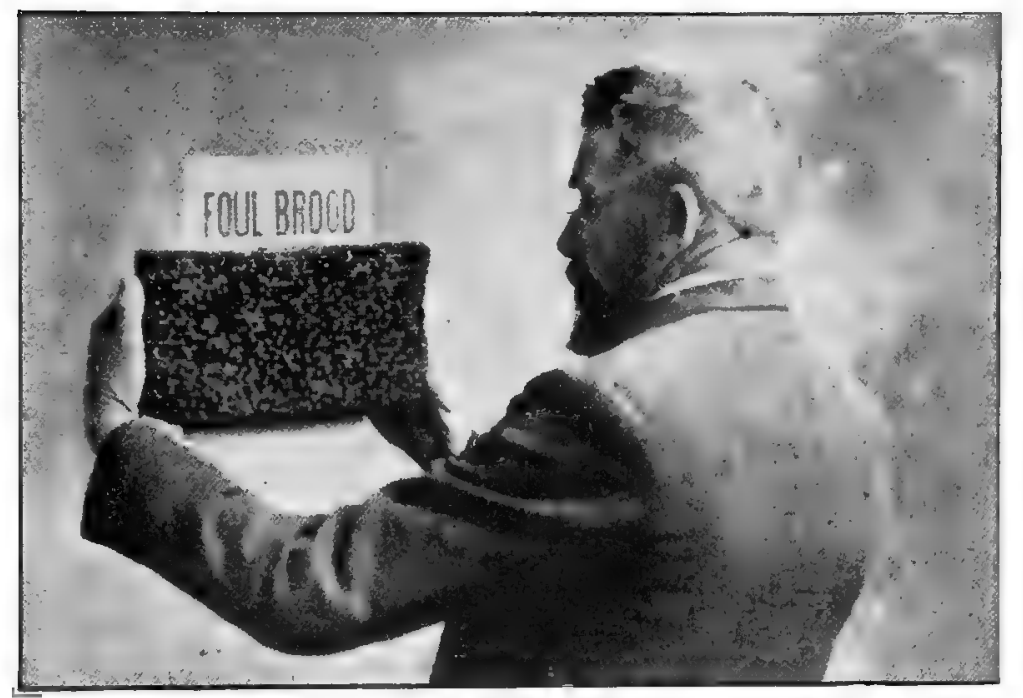

Inspector France looking for dried-down foul brood scales.

When the material in which the bacilli thrive becomes dry, they no longer continue to multiply, but form spores. This is a resistant stage in which they are able to withstand adverse conditions. When the bees use the cells containing dried scales of foul brood, these spores are present in large numbers, and any honey which may be placed in these cells immediately becomes infected with them. If brood is reared in such cells the spores come in contact with the larvae, are able to assume the active state again and continue to develop. In this way the disease appears and spreads anew. If contaminated honey from cells containing spores be fed to young larvae, the disease will thrive in all probability, appear in this brood and thus infect perfectly healthy larvae in clean cells. In this way the disease continues spreading in the hive until the contamination is so great that the colony succumbs, as it is impossible to rear any brood to maturity. 
Principal means of spreading the disease are transferring combs from one hive to another, and bees flying into wrong hives and carrying the disease with them. It is not uncommon to find that colonies ncarest to an infected colony have obtained the disease, while the rest of the colonies in the apiary, are entirely free from it. Bees carrying with them infected honey may spread the disease to other apiaries, as in the case of a storm overtaking flying bees and their taking refuge with healthy colonies several miles from home.

Robbing, in one form or another, is mainly responsible for spreading the disease. A diseased colony may become weak and bees from other colonies rob it out and carry the disease home, especially in the honey obtained. Thus the disease may be carried to other apiaries nearby by robber bees coming from them, and if this is not discovered and stopped in the early stage, bees of the entire locality may become infected before their owners are aware of the trouble. Exceeding care should, therefore, be exercised when handling colonies so

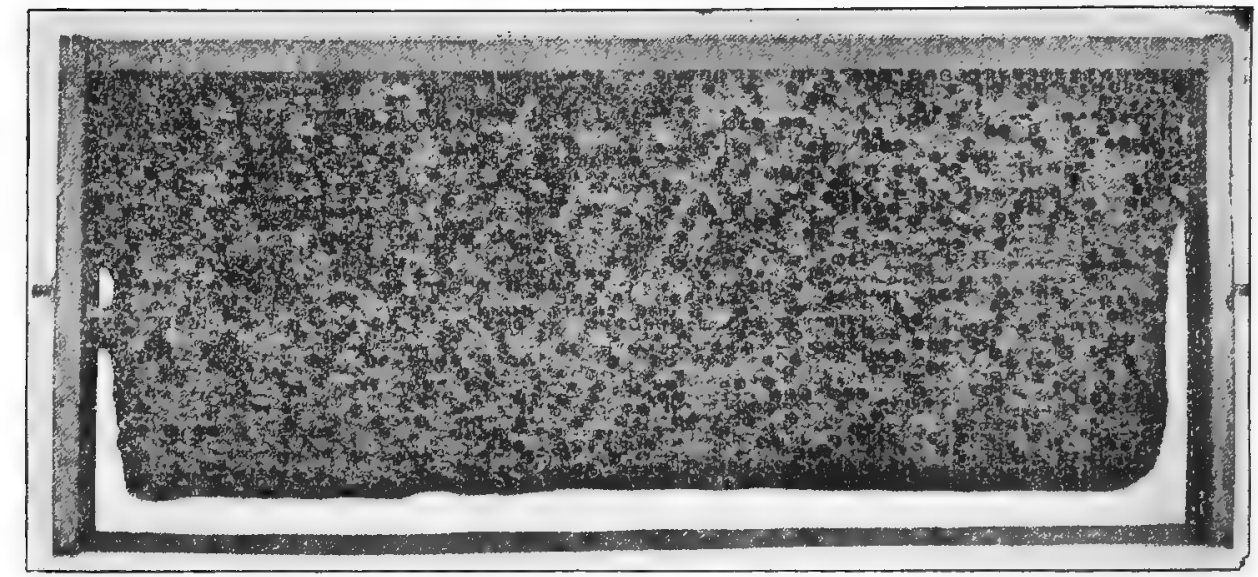

A badly diseased foul brood comb.

that robbing may not get started. Upon the least appearance of robbing, all hive manipulations should be stopped, and not be resumed until after sundown, at which time all necessary manipulations should be made.

Another way of spreading the disease is by using combs from colonies that have died out from some cause or another unknown to the beekeeper and which may contain foul brood germs or spores. Great caution should, therefore, be practiced in the use of combs from dead colonies. If death was caused by foul brood the indications for detecting the fact will generally be present. In colonies that have recently died, the pronounced smell of the decayed brood masses and the ropiness when examined with a toothpick, will reveal the cause immediately. At a later stage the combs may be examined for the dried down scales and if such are present, even if but a single one, they should not be used, as large numbers of spores are contained in one scale alone. 
The exposure of combs containing diseased honey about the yard, either carelessly or from an oversight on the part of the beekeeper, is a means of rapid spreading of the disease. Feeding bees with honey from combs which have contained diseased larvae is a most dangerous source of spreading foul brood, and the greatest care should be taken not to feed honey from an unknown source at any time. Exceeding care should also be taken when handling diseased colonies, not to have so much as a trace of diseased honey upon the hands, or clothing, for if there is the least particle, there is danger of carrying the disease to healthy colonies in the aniary. It is absolutely necessary that the hands and the tools used be washed very thoroughly with a disinfectant. It should be remembered that any practice which permits the transfer of honey, contaminated with the spores, to healthy brood will probably spread the disease, and all manipulations should, therefore, be made in such a way and with such care that this may be avoided.

European Foul Brood. The other disease, known as "black brood" or, more properly, European foul brood, has not as yet made its appearance in Texas. It is very similar to American foul brood, but some features of the disease are slightly different. Fewer of the larvae survive long enough to be capped over and, therefore, the sunken and perforated cappings are not as prominent as in the other disease. The larvae sink toward the base of the cell instead of the lower wall and do not present the same rotten mass and give off the odor of American foul brood. The dead brood gives off a sour smell, instead of the characteristic glue pot odor. The diseased larvae do not rope, or string out, like American foul brood when examined with a toothpick slowly withdrawn. Unlike the dried down scales of American foul brood, the scales of European foul brood can be removed by the bees from the cells, although many of them are not removed.

This disease is not as destructive, but spreads more rapidly than American foul brood, and, unlike the latter, it sometimes disappears without treatment. Although it is not now in Texas, every beekeeper should study this disease, as it may be introduced into the State with shipments of bees at any time. The methods employed for the eradication of European foul brood are identically the same as those given for the American kind.

$A$ Warning. If in doubt about the probable trouble when dead brood is discovered, samples of the comb containing diseased brood, should be sent to the State Foul Brood Inspector, at College Station, Texas, for identification.

The greatest care possible should be taken, however, about the manner in which the samples are packed for mailing. Do not, under any circumstances, send samples of diseased, brood in anything but a strong wooden or tin box, earefully wrapped in several thicknesses of strong paper. The dangers of spreading the dreaded diseases by exposing samples, are too great to permit any carelessness, or slovenliness, in this respect.

Beekeepers should have no fear of asking for any information regarding bee diseases, as such matters are kept strictly confidential. The foul brood law of Texas requires that all cases of foul brood, or 
other contagious diseases, must be promptly reported to the State Foul Brood Inspector. There should be no hesitancy about making these reports, as it is for the good of all concerned if prompt action is taken.

\section{GIVING TREATMENT.}

When bees are not inclined to rob, the diseased colonies may be treated safely without danger of spreading the disease to healthy colonies. It becomes necessary, therefore, never to undertake this unless during a honey flow when the bees are busy and will not molest when the diseased colonies are being manipulated. Toward evening, when most of the bees have ceased to fly, all the bees from the combs of the hive of the diseased colony are brushed into a clean hive, placed on the original stand, and containing frames with only narrow starters of comb foundation. The honey that the bees carry with them in their honey sacs will be consumed, and the wax produced will be used in drawing out the starters in a few days. After this

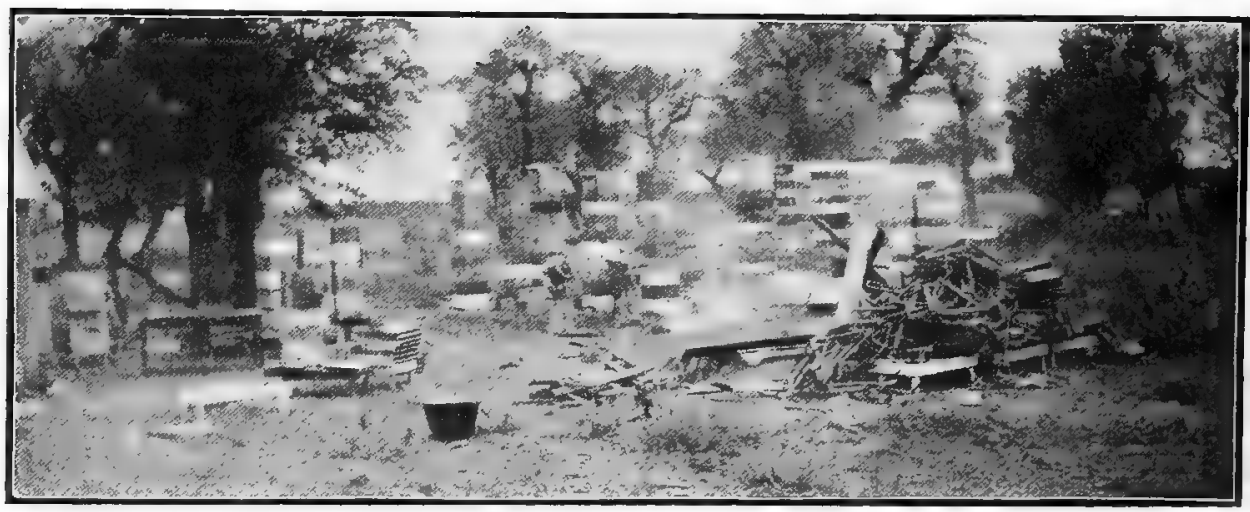

Wholesale treatment of foul brood.

time they should be shaken into another hive containing full sheets of foundation in the frames, and the bees should be fed a little daily if a new supply of nectar is not to be had.

The combs from the diseased colonies, from which the bees have been brushed, should be burned immediately, preferably in a hot brush fire built in a pit that has been previously dug for the purpose. This pit is to prevent diseased honey and melted wax from flowing over the ground and away from the fire and is to be filled up again over the ashes, being sure to shovel in the ashes and the soil next to the pit first, which may contain honey that dropped on the ground and remained unburned. The hives should be burned also, unless they are of a standard pattern, in which case they should be properly treated before using again. This is done by painting the inside with coal oil, tiering them up in a pile and then throwing into them a handful of straw previously lighted. The flames are allowed to singe the interior surfaces until they are charred, when a cover is quickly placed over them, and all drafts cut off by closing all the openings of the hives. Making sure that the flames are entirely ex- 
tinguished by the dense smoke that accumulates immediately, they are left to go through a heating process, which increases the efficiency of the treatment of the hives. All other apparatus, frames, tools, etc., which may have come in contact with diseased colonies, or their hives, should be carefully and thoroughly boiled in a solution of bichloride of mercury, one part in one thousand parts of water. The hands of the operator, and the tools assed by him, should be washed in a like solution. This solution is very poisonous, and must be used with great care. It will corrode any metal with which it comes in contact, and if used for washing such, it should be done quickly, and thoroughly rinsed off with clean water at once.

In apiaries where foul brood exists, starters of foundation are used in preference to full sheets where the combs are repeatedly destroyed. Any dried combs from diseased colonies may be rendered into beeswax in the usual manner, being careful at all times not to allow a single bee to have access to them. Before such wax is used for making foundation, it should be subjected to continuous boiling, or to live steam if such is handy, in order to kill all spores of the disease, which may otherwise be introduced into healthy colonies. Water, in which diseased combs or wax have been soaked, should never be thrown out without first thoroughly boiling the same, or killing the germs and spores by adding bichloride of mercury, or the bees may gather up the sweetened water and carry home the disease.

A modified method of treatment from the one given may be followed, in which case the combs of brood are not burned, but stacked up in hive bodies by themselves and the brood allowed to emerge. Only enough bees to properly keep the brood warm are left in these bodies, and all cracks and crevices are closed bee tight, and the entrance is reduced to only one bee space so that there may be no danger from robbing. This is one of the drawbacks of the method and, therefore, is not advised, since the danger of spreading the disease to other colonies by robber bees is too great, by far greater than the little saving of brood that may be contained in the diseased brood combs. In all cases where only a few colonies are concerned, the best and surest method of eradicating the disease from the apiary is to destroy the hives with their contents, combs and even the bees themselves, in order not to run any risk of not stamping out the trouble. This will remove all chance of further spread, and the fussing and bother connected with the ordinary method will be obviated. Since it does not pay to tamper with this disease, the most drastic measures will give the best results in the end.

\section{OTHER DISEASES.}

Pickled Brood. This disease is far less destructive than, and not as contagious as, foul brood, and is caused by a fungus growth, instead of bacteria. The diseased larvae, sunken to the base of the cells, are surrounded by a light colored viscid fluid which pickles them, and seems to prevent most of them from becoming dark colored, although some larvae become dark in color. Sometimes the disease shows slightly in a colony and remains for a long time without any 
marked change, while it may disappear of itself, even within a short time in most cases.

The bees continue to remove the dead larvae, but, in severe cases, they seem to be unable to keep this up, and in such instances the beekeeper should give his attention to the colony and treat it by brushing the bees into a clean hive as practiced in treating colonies for foul brood. This will hardly ever be necessary, however, except in severe cases. In general the disease has not done any considerable amount of damage; but, from numerous reports received during the spring of 1911, there was very much pickled brood present in some parts of the State, and considerable damage was done before the disease was chècked.

There are other forms of dead brood, caused by chilling, overheating, starvation or poisoning, but these are local in character and due to weather conditions, or faulty management.

Chilled Brood. This is frequently found in colonies in the spring immediately after a cold spell of weather. The dead brood is found mostly in the outer portions of the brood nest proper, caused by the bees being unable to cover the young brood sufficiently. Too open entrances, or cracks in the hives, are often a cause, whereas a colony in a good, tight and warm hive can take care of its brood even during an unexpected severe spell of cold weather. More often the beekeeper is at fault by deranging the brood combs during an examination and spreading the brood so the clustering bees can not cover the young brood. The bees will clean out the dead brood as soon as warm weather permits and will need no further attention unless the amount of chilled brood is very large.

Overheated Brood. During the summer overheated brood may be discovered, and the chief cause may be the lack of ventilation and too high a temperature on account of too small entrances to the hives or the lack of shade. Especial care should be given colonies when moving them in hot weather, or suffocation of both brood and bees may result in the destruction of the entire colony.

Starved Brood. Starved brood is caused by larvae dying for lack of sufficient and proper food, either by the colonies running short of stores during the fall after the close of the honey season, or before the opening of the honey season in the spring. It may occur, also, during a sudden eeasing of the honey flow at any time of the year. Properly feeding such colonies will restore them. This is easily done by giving combs of honey from strong colonies in exchange for their empty ones. There should be certainty that these combs contain no disease germs. If there is any doubt, sugar syrup should be fed.

Poisoned Brood. Poisoned brood is not often reported. It may be caused by fruit growers, or others, applying poison sprays while the fruit trees or other plants are in bloom, in which case the bees carry home the poison with the nectar or pollen gathered. Since such spraying is not done very largely in this State, there has been very little trouble from this source. The question has often been asked, whether the dusting of such poisons as Paris green and London purple upon cotton plants for the destruction of the "army leaf worm" would result dangerously to bees located within the reach of the fields. Since a good deal of such poisoning has been done on cotton 
plantations where large apiaries were located without showing any evil results, it may be surmised that there is little danger from this source. Since the nectar from the cotton plant is gathered from the nectaries located under the bracts of the "squares" and blossoms and from underneath the large leaves, there is little danger of the falling poison reaching these nectaries to any great extent. Consequently the bees, in gathering the nectar, would incur very little danger of being poisoned. The reader should turn back and read the chapter on "Poison Sprays and Bees" in the forepart of this bulletin.

Paralysis. A large number of inquiries are received every year, especially during the spring, regarding a trouble that is quite frequent in many parts of the State and especially so in North Texas. The bees appear to be very weak, and are affected with a trembling of the body, as if in great pain. They seem unable to control themselves and act as if they had lost power of direction over their limbs, sometimes some of their legs, and often of their wings, also. They are generally very smooth and glossy in appearance, owing to the loss of body hairs, and the diseased bees can be easily distinguished from the healthy ones. In mild cases only a few of these trembling bees may be discovered when the frames of the colony are manipulated, while everything else shows a most healthy condition. In severe cases, however, great numbers are affected; trembling, dying and dead bees will be found in front of the hive and a listless condition of the bees will be found in the interior.

In many instances the trouble ceases as soon as a flow of new nectar begins or new pollen is gathered. In other cases this does not have any effect upon the diseased colonies, and it is well for the beekeeper to take the matter in hand. The best form of treatment is to sprinkle powdered sulphur in the entrance and force it into the hives as far as it is possible to do so. The bees, in passing over the sulphur, will carry it farther into the hive, where it will have its effect. It is generally advocated to sprinkle the sulphur over the bees on the combs by removing them from the hives, but the sulphur has an evil effect upon the unsealed brood, killing all that it comes in contact with. For this reason, this method is not advised.

One of the handiest appliances is a cheap spray pump, so constructed that it has an opening large enough for a good blast of sulphur to be blown through it. By blowing the sulphur into the entrance with such an instrument, it can be forced well into the hives, and upon the lower edges of the combs, without doing any material damage to the brood, besides saving much time and extra labor. The application should be repeated in about four days, and again a week later, if needed. This will only be necessary in severe cases, however.

\section{BEE MOTHS.}

The most common complaint made by inexperienced beekeepers is, that the "worms" destroy the bees for them, but this is really a mistake, for worms never kill bees. The trouble in such cases is that the colonies often become weak as a result of queenlessness, and the 


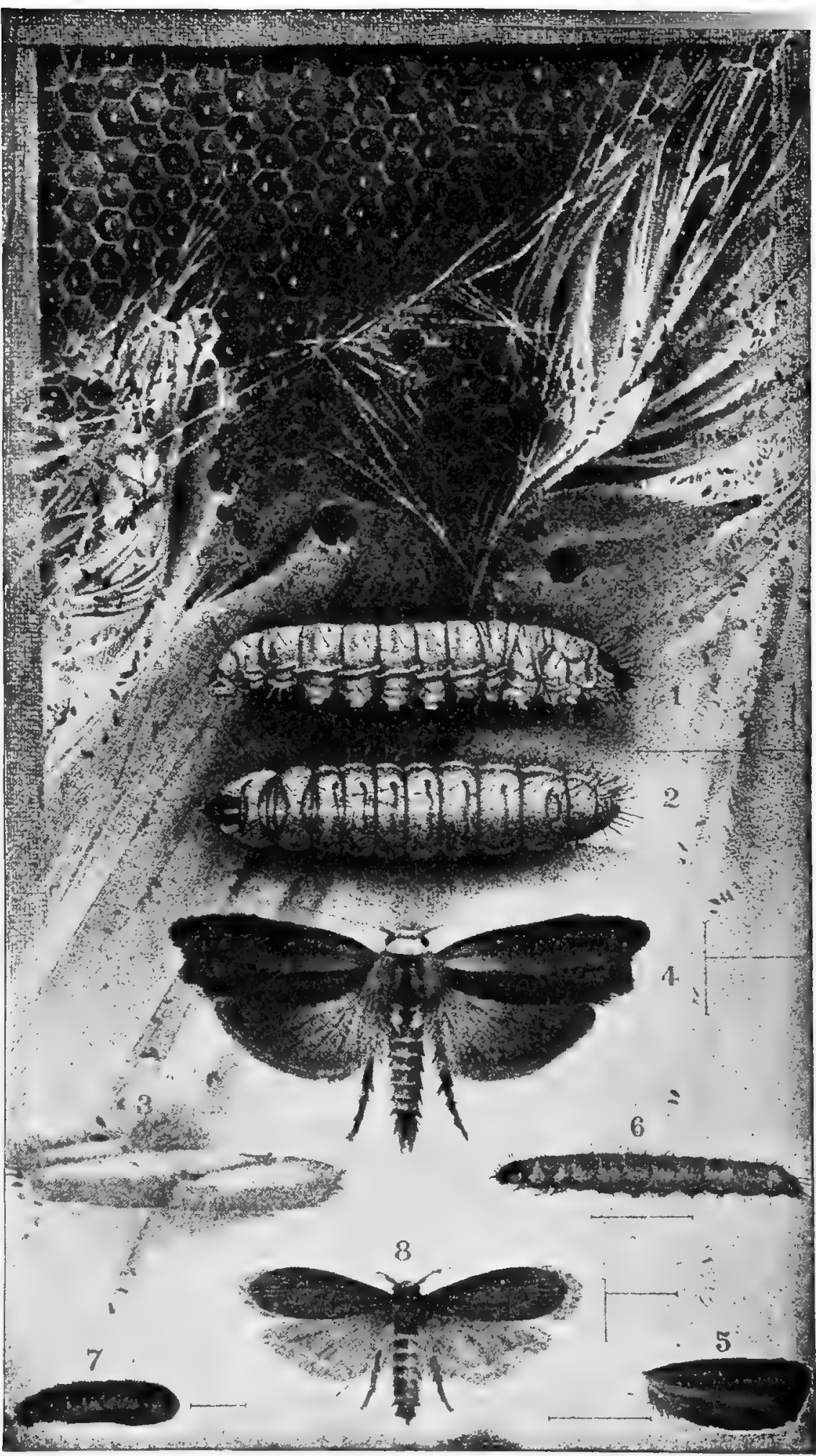


moths thereupon occupy the combs the bees can not care for. It often happens that colonies become weak from the ravages of diseases, which are undetected or neglected by the beekeeper. If left alone, these weak colonies are a source of infection to other colonies in the neighborhood, by being robbed. Since the moth makes its appearance and destroys these combs, which would otherwise be a menace, this must prominent enemy of bees is more nearly a friend in disguise. Keeping all colonies strong and having Italian, or other improved bees, in good tight and clean hives, will prevent any trouble from their depredations. With common black bees, or their crosses, the wax moth is much more persistent, and for this reason it pays to improve the stock of bees.

The adult insect is a small moth, brownish gray in appearance, which lays its eggs on the combs or in crevices about the hives. The eggs will hatch into small larvae which feed upon the combs. They prefer those containing stored pollen or in which brood has been reared. In working their way through the comb, the larvae tunnel beneath the surface of these, keeping out of the reach of the bees as much as possible. They line their tunnels with a thin silky web as they proceed, and grow larger in size from day to day. When they have reached their proper age they spin cocoons, from which they emerge after a time as full grown moths. From this it will be seen that the so-called "worms" are nothing but the larvae of the wax

\section{EXPLANATION OF FOREGOING PLATE}

The full page illustration of the two specles of beeswax-moths was obtained through the courtesies of the A. I. Root Co., of Medina, Ohio, publishers of A B C \& X Y Z of Bee Culture. It is from an article on the subject by Mr. Sidney Olliff, the Government Entomologist for New South Wales, Australia, reproduced in the above work from the Agricultural Gazette. The plate is from a drawing by Mrs. E. M. Grosse and the explanation follows:

\section{Beeswax-Moths.}

Fig. 1.-Larva or caterpillar of Larger Beeswax-moth (Galleria mellonella, Linn.), side view (much enlarged).

Fig. 2.-The same viewed from above (much enlarged).

Fig. 3.-Cocoon of same, extracted from bee-comb (enlarged).

Fig. 4.-Larger Beeswax-moth (Galleria mellonella, Linn.), male (much enlarged).

Fig. 5.-Forewing of same, female.

Fig. 6.-Larva or caterpillar of Lesser Beeswax-moth (Achria grisella, Fabr.), side view (much enlarged).

Fig. 7.-Pupa or Chrysalis of same (much enlarged).

Fig. 8.-Lesser Beeswax-moth (Achria grisella, Fabr.), (much enlarged).

In the background above, a comb from a frame hive is represented, show-

ing brood comb tunneled by the larvae of the larger beeswax moth (Gelleria mellonella, Linn.).

The natural sizes of the insects are indicated by hair-lines. 
moth, and that they do the damage to the combs in their larval stage. The moths are very quick in their flight and movements. They will enter any colony that is not able to defend itself, and are often found in fairly strong colonies of black bees. They also lay their eggs in openings and crevices of hives of the colonies, and when the larvae emerge, they find their way into the hives. Strong colonies will keep them from doing any harm, however, while they may gain ready headway in weak colonies and destroy all of the combs within a short time. The combs upon which they work are very rapidly reduced to a mass of webbs and cocoons, and are thus completely ruined.

All combs not in use should be protected by giving them to the care of strong colonies of bees. If this is not possible they should be placed in tight hive bodies and stacked up in piles, leaving an empty

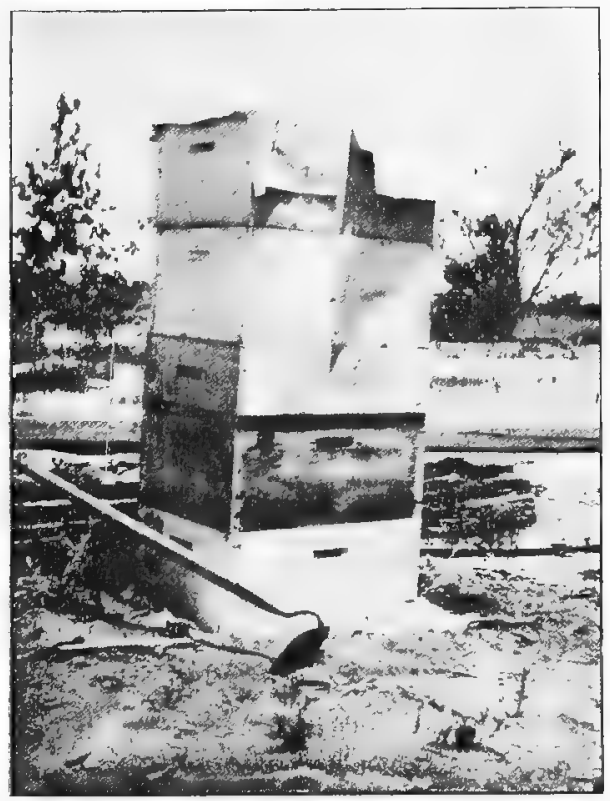
hive, or any sort of tight box, below, from which the combs can be fumigated with sulphur fumes. A more satisfactory way of fumigating these is by the use of bisulphide of carbon, a liquid, which may be obtained at any drug store. Care should be taken, however, in handling this, as it is highly inflammable, and the vapor from it should not be allowed to come near a flame. The combs to be fumigated should be put in a tight box, and the liquid placed in it above them in a shallow saucer, and the fumes, which are heavier than air, will find their way down through the combs. Where combs are badly infested with was-moth larvae they may be treated in the manner shown in the illustrations on pp. 130 and 131. After digging a shallow trench, the length and width of the hives, in the yard, and laying down a few newspapers, the stack of hives with the combs is set on these. Water is then poured around the hives to make these air tight. An empty hive is set over the top into which a saucer full of bisulphide of carbon is placed. Wet newspapers are then laid over the top as shown, and the whole is then covered over tightly with a large wagon sheet, or a tarpaulin. The lower edges of this are tucked snugly against the pile of hives about the ground and left for the fumes to do their deadly work.

The beekeeper should refrain from leaving any particles of wax or combs lying about the apiary, the honey house or shop, as these afford breeding places for the moths, and furnish a supply of moths 
that may continue to do damage in the apiaries. With a little care the number of moths can be kept down materially and the danger from this source decreased. Keeping all the colonies strong and in good hives will enable any beekeeper to protect his bees against the ravages of the wax moth larvae, and there is no excuse for the constant, and often heavy losses, attributed to their depredations. The progressive beekeeper does not fear them as an enemy.

There is another and smaller wax moth, known as the "Lesser wax moth," that does a good deal of harm to the cappings of stored combs. Fancy comb honey is often spoiled by the larvae of these little moths tunneling through the delicate cappings of the combs. Their presence may be noticed by the fine dust-like trails over the comb surface. Fumigation should be resorted to immediately upon such discovery. The moths are slightly more

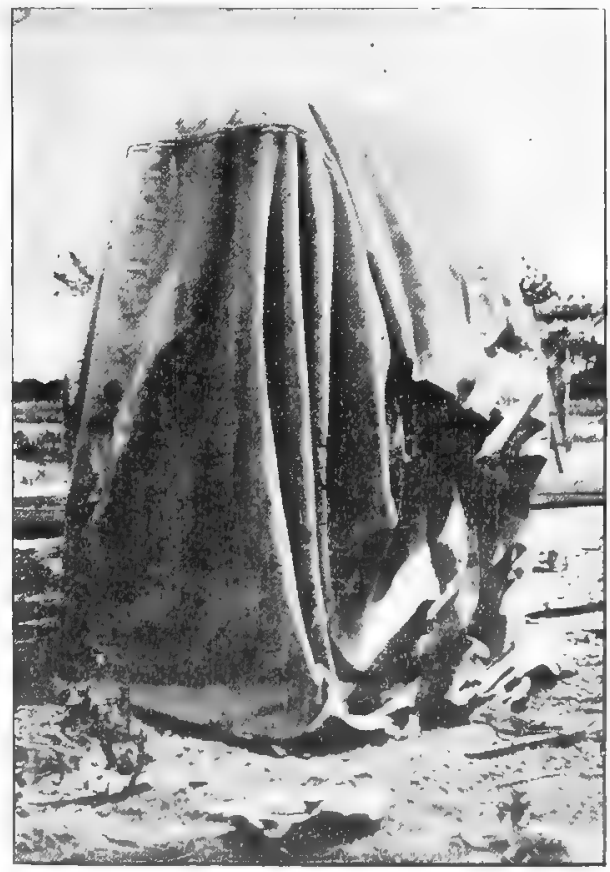
than half the size of the common wax moth. They are silvery gray in appearance and swift in movement and flight. They need not be feared any more than the larger moth.

OTHER ENEMIES.

Mice. Sometimes great damage is done to the combs stored away over winter by mice getting to them; but, with a little care in keeping the combs out of their reach, or in closed hives or boxes, they need not be feared. Occasionally they will find their way into hives of bees where they like to nest, because of the warmth coming from the cluster of bees. In doing so they are very destructive to the combs. Entrances to the hives, therefore, should not be more than $3 / 8$ inch in depth. Since bees object to occupying hives and supers which smell of mice, they should be kept away from them by constant trapping.

Since mice are very fond of old combs and honey, they can easily be caught by placing several of the small flat spring traps upon such pieces of comb honey, in a shallow pan about three inches high. Outside of the pan a piece of brick, or the like, is placed immediately opposite each of the traps, so that the mice, in climbing into the pan 
over these, jump right into the trap. Poison should never be used about bee hives, or where honey is kept, as it is too dangerous.

Ants. Many inquiries are received asking for information about destroying ants, which are a considerable bother in the apiary at times. As a rule, not much harm is done by them, but they are annoying about the hives. Of these there are several kinds, mostly the smaller ones, that try to get some of the honey, but do not attack the bees. It is only in rare cases that some of the larger varieties are destructive to bees. They can easily be killed with bisulphide of carbon after hunting up their nests. A deep hole is made in the nest with a crow-bar and a tea-cup full of bisulphide of carbon is poured into it, and then covered up and packed tightly with earth. For the smaller kinds it is only necessary to make a hole with a small stick for the bisulphide of carbon, and it may often be poured right on the nests and earth firmly packed over it, as the fumes penetrate into the soil and go downward. It is a mistake to set fire to the bisulphide of carbon in treating ant nests, as many persons do, because the fumes are then burnt up and the effectiveness of the remedy lost. Common sasoline, kerosene, or even hot water, may be used effectively in some cases.

It is not advisable to use poisons to kill ants about the apiary or in the honey house, and should never be attempted.

Skunks, The depredations of this little animal are sometimes quite serious. They scratch on the front of the hives, and devour the bees as they come out to investigate the cause of the disturbance. When hives are found, in front of which the grass, weeds and soil are scratched away, and quantities of partly chewed masses of bees are found, it is a sure sign that skunks are bothering the hives.

As these marauders repeat their visits continuously the colonies are weakened considerably, so that some colonies may suceumb entirely on account of their weakened condition. They may be best destroyed by trapping them. By partly burying an egg in the ground near the apiary where the skunks depredate and setting a spring steel trap over this they may be easily caught. A little strychnine stirred in an egg will poison them, but great care should be taken to prevent undesirable results that may be caused by using poisons.

Birds. Birds are often accused of doing more damage than is perhaps committed by them. Usually reports of their depredations are greatly exaggerated, and frequently are entirely false. In queenrearing yards the damage may be enhanced by the birds catching the queens while they are out to mate. Occasionally a bird of the insectivorous kind may acquire the habit of eating bees. The king-bird is reported as doing most of such damage. Therefore, it does not become necessary to make a general warfare against all the birds if only a few individuals are the guilty ones. Whenever it is certain that a bird persists in this habit he should be promptly killed. On the whole, however, birds should receive the beekeeper's protection, as their services in destroying harmful insects are far more valuable than the little damage done by a few birds eating a small number of bees.

Spiders. There are a number of varieties of spiders that build their nests about hives, and the bees becoming entangled in the webs, 
are lost. The only remedy is not to have any openings, or crevices, near the entrances of the hives, in which spiders may harbor. Webs should be removed and the spiders destroyed, whenever opportunity offers, while performing the work in the apiaries.

Robber Flies. Occasionally large robber flies destroy bees by catching them while in the air. These flies suck the juices from the bees and then cast the bodies aside to catch others. Some individuals have been watched and found to catch and suck the juices from as many as seven bees at a timc. They are, however, never numerous enough to do any great amount of harm, and there is no remedy whenever they appear in large numbers about the apiary, except to kill them with a long slender paddle or by means of a long switch. They need not be feared, however, even if they do catch a few bees.

Bee Lice and Mites. Considerable notice is being given to what is termed the "bee louse" which causes considerable bother in Italy, and is sometimes imported with queen bees. It is not present to a serious extent in Texas.

Sometimes mites infest bees, but reports of serious injury done by them is wanting.

Bees lose their vitality, or the stock becomes run down, from long continued inbreeding, and are then more susceptible to the ravages of diseases and enemies. Therefore, the introduction of new blood will greatly aid in overcoming these obstacles and this should be encouraged.

\section{WINTERING.}

Unlike the long chapters on this subject in nearly all the text books and other publications, the chapter on wintering bees in the South is the shortest in this bulletin. This is because the wintering problem needs no serious consideration other than to see that the bees are well housed in good, tight hives and are supplied with a sufficient supply of honey for their winter food.

Preparation of the colonies should begin early in the fall of the year, seeing that each colony has the necessary amount of stores, at least 30 to 40 pounds of honey, in the combs of the brood chamber and in close proximity to the brood nest. More honey will be better, especially if the winter season happens to be a long one. It will not be lost or wasted if not needed, but will aid materially in the production of large quantities of brood during the early spring months, which means rousing colonies of bees later when the honey flow begins. These are the colonies from which the largest amount of surplus honey may be expected. It pays, therefore, to have them provided with honey enough to last, not only through the winter months, but far into the spring. It is at this time that large quantities of honey are needed on account of the excessive brood rearing and the building up of the colonies.

No special protection to the hives is necessary if the apiary is located as described in the chapter, "Locating the Bees in the Apiary." If they are very much exposed to the winds and weather, it is advisable to provide some temporary protection on the north side. Simply placing wide boards against the hives at this place will answer. 


\section{EDUCATIONAL.}

In this day of specialization, it is necessary for one to master the methods of application and management needful for success in any particular line it is decided to follow, and beekeeping is not an exception to the rule. The man who devotes his whole time to this pursuit can not expect to succeed without knowing how to properly conduct apiaries and obtain large crops of honey and sell same to advantage. Beekeeping, today, does not only require a general knowledge of keeping bees and producing a honey crop; but, to make the venture a successful one, it is necessary that a thorough knowledge of business requirements be possessed. It should be remembered that it is one thing to produce a large erop of honey and another to sell it profitably. Some people take naturally to the business, having a special aptitude for it, while others with more or less difficulty educate themselves to meet its requirements. For the determined person, in either instance, it can be truly said there is assured success, provided the location is good and misfortune is not encountered that is beyond human control.

\section{FIELD MEETINGS}

One of the most effective steps toward inspiring the interest of beekeepers in their work, is the coming together of two or more individuals and the discussion by them of the various practical topies in which they are directly interested. For this reason visiting among beekeepers is to be encouraged. A visit to a neighboring beekeeper may result in bringing up questions that might not have been thought of otherwise, and the same may be said of a visitor entertained at one's own door. Exchanging views on beekeeping subjects has a tendency to clarify ideas and to enable one to see things in a better light. The beginner, or amateur, coming in contact with the more experienced, or older members of the craft, is certain to learn from

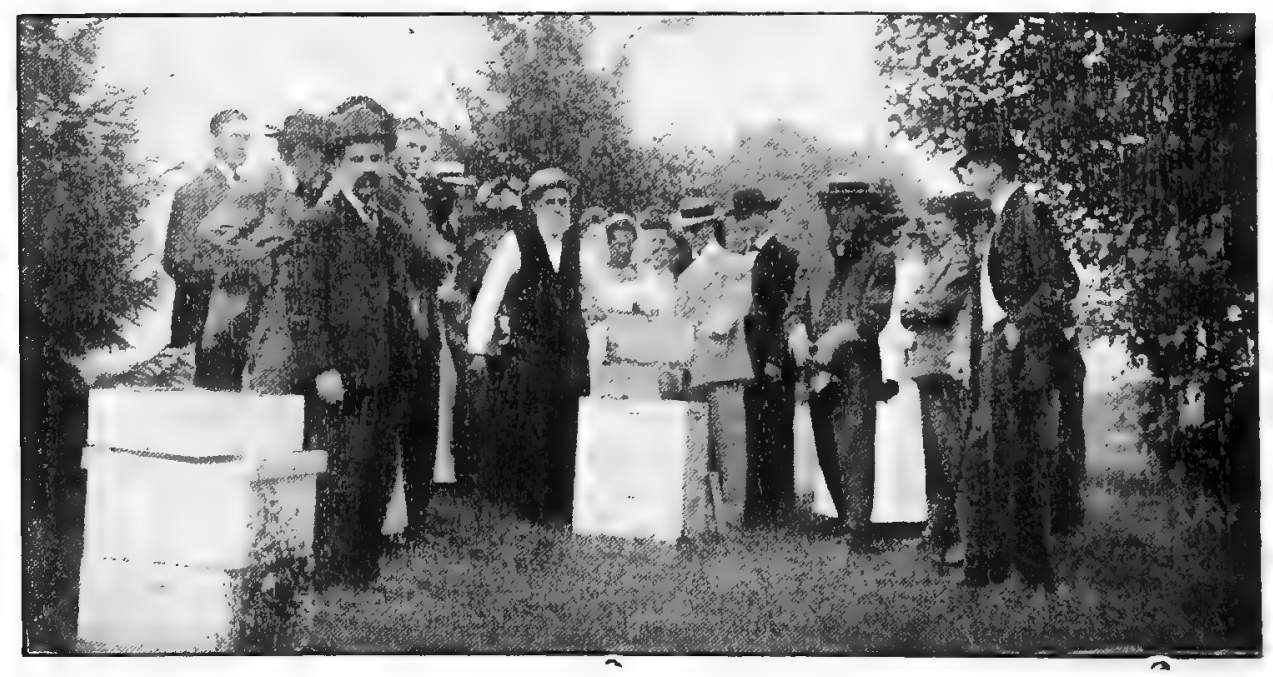

Gatherings that are profitable. 
them much of value. It frequently happens, also, not only to the younger inexperienced, but even those advanced in years, that they will gain knowledge of little things that they can turn to good account in their operations.

One of the most pleasurable ways in which these educational features may be enhanced is by holding what is termed "field meetings." These gatherings are usually at some centrally located apiary, where beekeepers from the surrounding territory assemble for the purpose of social enjoyment and educational benefit. It is not a necessary condition precedent to good results that these meetings shall be attended by a large number of beekeepers. Even if there are only a few of them in the territory, much may be accomplished by such gatherings. It is hoped that such field meetings will be encouraged in the various parts of this State. These being generally held, would mean much for the betterment of apicultural conditions, both from a financial and a social standpoint.

\section{BEEKEEPERS' ASSOCIATIONS.}

Another important matter is that of attending beekeepers ${ }^{7}$ conventions. They are of utmost importance, for there is no other place at which the various subjects, in which beekeepers are interested, can be threshed out so satisfactorily. There is not only submission, discussion and dissemination of knowledge pertaining to keeping bees and the production and marketing of crops of honey, but there is afforded opportunity to formulate co-operative action, that can be later carried into effect to the great advantage of all concerned. Conventions, too, mean the forming of associations; associations mean organization and organization means greater certainty of success. It is hoped that we may find beekeepers' associations more common in the large fields in this State. For some reason the interest has waned in this respect during the last few years. Whereas there were as many as eight different beekeepers' associations ten years ago, there are only two active associations now. The Texas Beekeepers' Association, which is the State association, is the larger of the two. Its regular annual meetings are held at College Station, Texas, during the time of the meeting of the Texas Farmers' Congress, of which it is an affiliated section. The meetings are generally held during the summer vacations of the College-a most suitable time, since the student rooms in the various dormitories can be used for those in attendance, free of any cost. It is also possible, with the large mess hall facilities, to take care of the large numbers in attendance, at a nominal cost for meals. It is hoped that greater interest will be shown during coming years in increasing the attendance and the membership of this organization. The annual dues are $\$ 1$ a year. This charge includes membership in the National Beekeepers' Association, which the members of the Texas Beekeepers' Association join in a body at $50 \mathrm{c}$ per member. This association is a national organization, and its objects are to increase and further the welfare of beekeepers in general, and to protect its members at the same time. Besides this, a reduction has been allowed to members of the association, on the subscriptions to the various bee journals. Its 
secretary, W. T. Childress, Batesville, Texas, will give any further information desired. Information regarding the National Beekeepers' Association may be obtained from the secretary, E. B. Tyrell, 230 Woodland Ave., Detroit, Mich.

\section{EXHIBITING AT FAIRS.}

Few beekeepers fully realize the benefits that may be derived from exhibiting at fairs. Exhibitions of bees, apiary products, hives, and the various appliances needed, give the beekeepers an opportunity to show the vastness of the industry, and to favorably advertise their business. Such displays create interest among the mass of people who visit the fairs, and thus open a way to a market for the beekeepers' products. Too few of our beekeepers take advantage of fairs, but the time is looked for in the very near future when beekeepers' exhibits will be more in evidence at them. This subject should receive more attention.

Very creditable beekeepers' exhibits have been made at the larger fairs during the last few years; but, even these should have received more attention from the majority of Texas beekeepers. It is encouraging to note that local fairs, at various places, have had good displays of this kind in recent years.

\section{BOOKS ON BEEKEEPING.}

The average uninformed person has a mistaken idea regarding the magnitude of the beekeeping industry, believing it to be of minor importance. This is illustrated by the following remark made not long ago: "Why, beekeeping is getting to be a great thing these days. There is even a book published on bees!" The fact is, the list of books on the subject of beekeeping is a large one. There are a number of ancient books upon this subject. One in the author's library, "The True Amazons, or the Monarchy of Bees," an English work by James Warder, bears the date of March 12, 1721.

The value of good books on beekeeping is inestimable. Supplying himself with one or more of them should be the first item on a beginner's purchasing list when making a start. The experienced beekeeper will not be without them, and there are many who have very complete libraries of publications pertaining to apiculture.

The following is a list of practical books on beekeeping:

A B C \& X Y Z of Bee Culture. By A. I. Root and E. R. Root. A most widely read work on apiculture and encyclopedia of information for amateurs and professional beekeepers alike. 576 pages; price, $\$ 1.50$.

How to Keep BeEs. By Anna Botsford Comstock. A charm. ingly written manual, especially for amateurs, describing all the necessary details of beekeeping. 228 pages; price, $\$ 1$.

Fifty Years Among the Bees. By Dr. C. C. Miller. A most popular book written by one of the most widely known writers on the subject. 352 pages; price, $\$ 1$.

Manual of the Apiary. By Prof. A. J. Cook. A very complete treatise on bees and beekeeping, particularly valuable to those inter- 
ested in the anatomy and physiology of the bees. 540 pages; price, $\$ 1.15$.

Langstroth on the Honey Bee. By C. P. Dadant. It has a vast fund of information on all subjects relating to practical bee culture. 575 pages; price, $\$ 1.25$.

Advanced BeE Culture. By W. Z. Hutchinson. Although a most valuable book for the advanced beekeeper, the beginner will find it exceedingly helpful. 200 pages; price, $\$ 1$.

DoolitTle's Queen Rearing. By G. M. Doolittle. It is practically the only comprehensive book on queen rearing. 124 pages; price, $75 \mathrm{c}$.

Quinsy's New BeEkeEPING. By L. C. Root. Of especial interest to those who want to know the early work on beekeeping. 270 pages; price, $\$ 1$.

Amerikanische Bieneneucht. By Hans Buschbauer. A beekeeper's handbook in the German language. 138 pages; price, $\$ 1$.

Southern Bee Culture. By J. J. Wilder. A treatise on beekeeping in the South. 145 pages; price, 50e.

A Modern Bee Farm. By S. Simmins. Written by an English beekeeper acquainted with American methods. 430 pages; price, $\$ 2$.

How to Keep Bees for Profit. By D. Everett Lyon. This is one of the newer books on the subject. 330 pages; price, $\$ 1.10$.

Practical Bee Guide. By J. E. Digges. A guide to the beekeeping industry of Ireland. 220 pages; price, $\$ 1.20$.

BRITISH BeEkeEPeR's GUIDE Book. By T. W. Cowan. This is the leading work on practical beekeeping in England. 245 pages; price, $\$ 1$.

The Honey Bee. By T. W. Cowan. A work on the natural history, anatomy and physiology of bees. 220 pages; price, $\$ 1$.

WAX Craft. By T. W. Cowan. An extensive treatise on beeswax, 180 pages ; price, $\$ 1$.

First Lessons in Beeremping. By C. P. Dadant. A new revision of the old book by Thos. Newman. 200 pages; price, 50c.

For those who prefer to have a book treating the subject of beekeeping in the German language, we recommend the German edition of the "A B C \& X Y Z of Bee Culture," and "Amerikanische Bienenzucht." The former is also published in French.

There are a number of popular works on bee culture, written for the most part by writers of literary ability, which are very interesting and valuable.

The Bee People. By Miss Margaret W. Morley. Written especially for children, but interesting to older persons. 190 pages; price, $\$ 1.50$.

The Children's Story of the Bee. By S. L. Bensusan. Although written for children, it is an interesting and entertaining volume. 250 pages; price, $\$ 2$.

The Honey Makers. By Miss Margaret W. Morley. The story of the life of the bee written in very interesting style. 424 pages; price, $\$ 1.50$.

THE LIFe of tHe BeE. By Maurice Maeterlinck. A beautifully written volume on the honey bee. 425 pages; price, $\$ 1.40$.

The LORE OF THE HoNeY BeE. By Tickner Edwards. An interesting book of information about bees in general. 280 pages; price, $\$ 2$. 
Queenie. By T. Chalmers Potter. An autobiography of an Italian queen; poetical. Price, 75c.

The Bee Master of Warrilow. By Tickner Edwards. An interesting English story. Price, 60c.

\section{BEEE JOURNALS.}

Next in importance to owning a good book on beekeeping, is subscribing for one or more bee journals. The beginner should aim, if possible, to include in his initial investment a year's subseription to
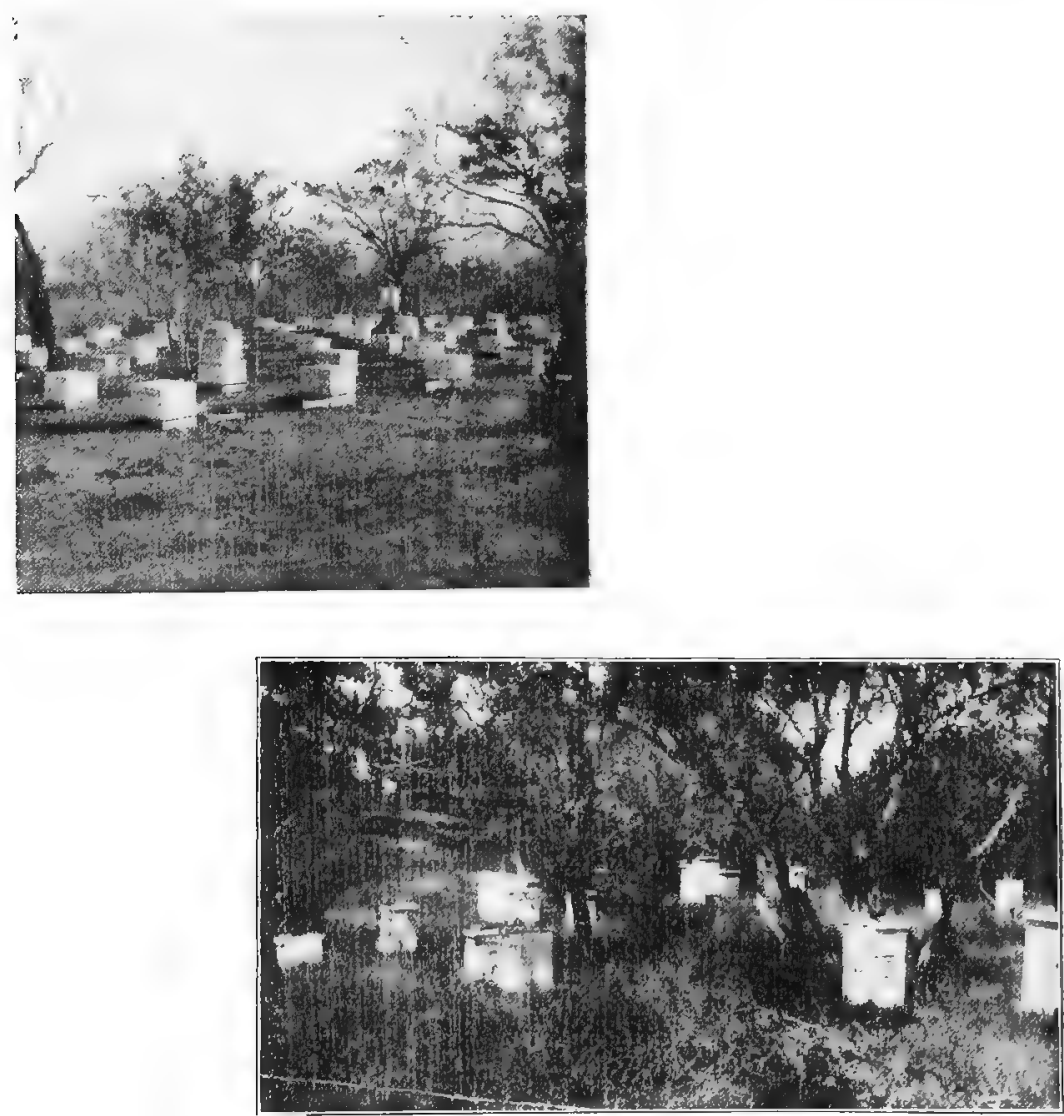

Apiaries of Bee Journal Readers.

one of the bee journals published in this country. While the bee book is an excellent guide, as far as the management of becs is concerned, there is nothing that will so aid in keeping a beekeeper informed on current topies, and new ideas and methods of management as reading bee journals. Especially is this a great benefit during the marketing season, as it will enable the beeketper to keep in tou.h with the market situation and the prices of apiarian products. 
Three journals, exclusively devoted to beekeeping, are published in the United States. While either one may be selected, if only one is to be chosen, all of them may well be subseribed for, and that without fear of finding a repetition of the same subject matter in two or more of them. While they all seek to cover the same ground, in general, the scope of beekeeping is so broad, the field such an extensive one, and the subjects so large in number, that a great varien of instructive matter is furnished to those who read them all.

American Bee Journal. Published at Hamilton, IIl. The ollest bee journal in America. A well illustrated monthly, at $\$ 1$ a year.

Greanings in Bee Culture. Published at Medina, O. Profusely illustrated and issued semi-monthly, at \$1 per annum.

Beekeeper's Review. Published at Detroit, Mich. An illustrated journal especially valuable for the advanced beekeeper. Monthly, $\$ 1$ per year.

The two first named bee journals each have a "Southern Department," edited by the author of this bulletin. The purpose of this feature is to make them better suited for beekeepers of the South.

\section{BINDING PUBLICATIONS.}

Preserving the various periodicals pertaining to beekeeping for future reference is a valuable item that should be considered more by beekeepers. It is too often found that the bee journals are de-
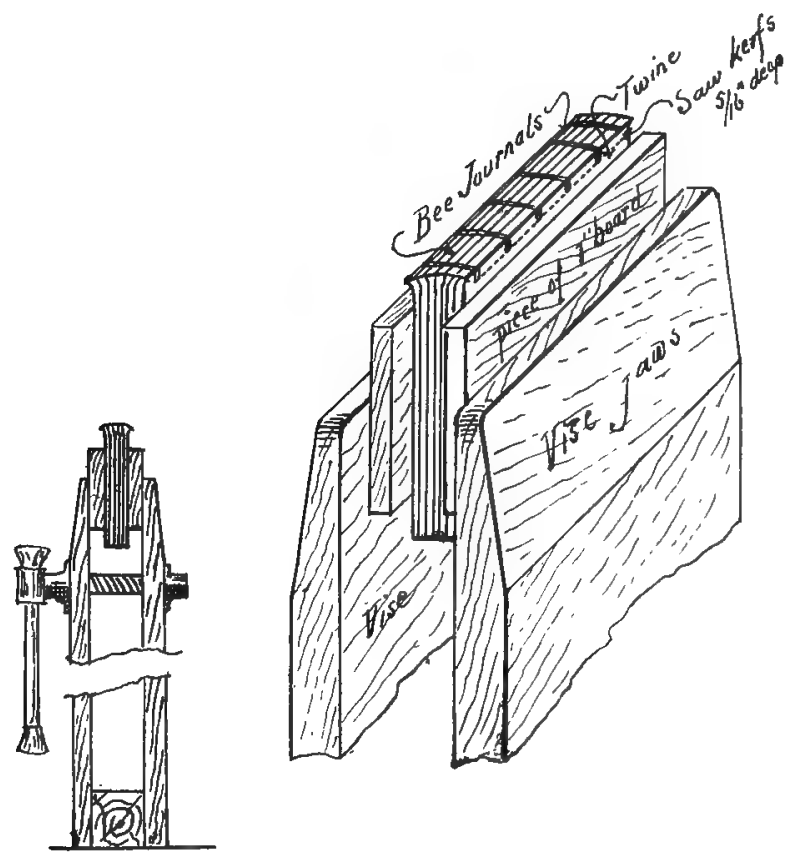

stroyed as soon as they have been read. If the numbers of eack yearly volume are kept together in a suitable way, they prove to b. very helpful whenever it hecomes necessary to refer to articles sum 
tained in them. The files also furnish a chance to read much in long winter evenings that it was impossible to more than glance at, if notice at all, during the busy summer season.

For these reasons it is advisable that bee journals be carefully preserved, and, at the end of the year, bound into solid book form, as shown in the accompanying illustration. After placing the volume into the vise, as shown, saw kerfs are cut across the back of the journals, and, after applying a goodly quantity of flour paste or liquid glue in these and on the backs of the journals, strong twine is tightly wrapped through the saw kerfs and from one to the other in such a way that the entire volume is firmly held together. Applying another even coat of glue to the backs of the journals, a strip of fiannelette, or any cotton eloth, is placed over the slue. To add to the neatness of the bound volume, a wide piece of strong eloth or heavy paper may be glued over the book, to cover the exposed portion of the twine and the saw cuts. The edges of the volumes may be trimmed by a stationer, or at a printing office, with a large paper rutter Card board covers may also be added if desired. Wherever it is possible to have this done, the volumes may be sent to a book binder.

\section{UNITED STATES BULLETINS ON BEES.}

A number of valuable bulletins on various subjects of interest to beekeepers, are published by the Department of Agriculture. They are prepared in the Burean of Entomology and are for free distribution. The following may be obtained by addressing the Secretary of Agriculture, Washington, D. C.:

Farmers' Bulletin No. 447, "Bees." By E. F. Phillips, Ph. D. 1911. 48 pp., 25 figs.

A general account of the management of bees.

Farmers' Bulletin No. 442, "The Treatment of Bee Diseases." By E. F. Phillips, Ph. D. 1911. 22 pp., 7 figs.

This publication gives briefly the symptoms of the various bee diseases, with directions for treatment.

Circular No. 94, "The Cause of American Foul Brood." By G. F. White. Ph. D. 1907. 4 pp.

This publication contains a brief account of the investigations which demonstrated for the first time the cause of one of the brood diseases of bees, American foul brood.

Circular No. 138. "The Occurrence of Bee Diseases in the United States. (Preliminary Report.)" By E. F. Phillips, Ph. D. 1911. $25 \mathrm{pp}$.

A record of the localities from which samples of diseased brood were received prior to March 1, 1911.

Bulletin No. 55, "The Rearing of Queen Bees." By E. F. Phillips, $\mathrm{Ph}$. D. 1905. 32 pp., 17 figs.

A general account of the methods used in queen rearing. Several methods are given, so that the beekeeper may choose those best suited to his individual needs.

Bulletin No. 70, "Report of the Meeting of Inspectors of Apiaries, San Antonio, Texas, November 12, 1906." 1907. 79 pp., 1 plate. 
Contains a brief history of bee-disease investigations, an account of the relationship of bacteria to bee diseases, and a discussion of treatment by various inspectors of apiaries and other practical beekeepers who are familiar with diseases of bees.

Bulletin No. 75, Part I, "Production and Care of Extracted Honey." By E. F. Phillips, Ph. D. "Methods of Honey Testing for Beekeepers." By C. A. Browne, Ph. D. 1907. 18 pp.

The methods of producing extracted honey, with special reference to the care of honey after it is taken from the bees, so that its value may not be decreased by improper handling. The second portion of the publication gives some simple tests for adulteration.

Bulletin No. 75, Part II, "Wax Moths and Arnerican Foul Brood." By E. F. Phillips, Ph. D. 1907. Pp. 19-22, 3 plates.

An account of the behavior of the two species of wax moths on combs containing American foul brood, showing that moths do not destroy the disease-carrying scales.

Bulletin No. 75, Part III, "Bee Disease in Massachusetts." By Burton N. Gates. 1908. Pp. 23-32, map.

An account of the distribution of the brood diseases of bees in the State, with brief directions for controlling them.

Bulletin No. 75, Part IV, "The Relation of the Etiology (cause) of Bee Diseases to the Treatment." By G. F. White, Ph. D. 1908. Pp. 33-42.

The necessity for a knowledge of the cause of bee diseases before rational treatment is possible is pointed out. The present state of knowledge of the causes of disease is summarized.

Bulletin No. 75, Part V, "A Brief Survey of Hawaiian Beekeeping." By E. F. Phillips, Ph. D. 1909. Pp. 43-58, 6 plates.

An account of the beekeeping methods used in a tropical country and a comparison with mainland conditions. Some new manipulations are recommended.

Bulletin No. 75, Part VI, "The Status of Apiculture in the United States." By E. F. Phillips, Ph. D. 1909. Pp. 59-80.

A survey of present-day beekeeping in the United States, with suggestions as to the work yet to be done before apiculture will have reached its fullest development.

Bulletin No. 75, Part VII, "Beekeeping in Massachusetts." By Burton N. Gates. 1909. Pp. 81-109, 2 figs.

An account of a detailed study of the apicultural conditions in Massachusetts. The object of this paper is to point out the actual conditions and needs of beekeeping in New England.

Bulletin No. 75, Contents and Index. 1911. Pp. viI +111-123.

Bulletin No. 75, Parts I-VII, complete with Contents and Index.

1911. Pp. vIII+123.

Bulletin No. 98. "Historical Notes on the Causes of Bee Diseases." By E. F. Phillips, Ph. D., and G. F. White, Ph. D., M. D. (In press.)

A summary of the various investigations concerning the etiology (cause) of bee diseases. 
Technical Series, No. 14, "The Bacteria of the Apiary, with Special Reference to Bee Diseases." By G. W. White, Ph. D. 1906.50 pp. A study of the bacteria present in both the healthy and the diseased colony, with special reference to the diseases of bees.

Technical Series No. 18, "The Anatomy of the Honey Bee." By R. E. Snodgrass. 1910. 162 pp., 57 figs.

An account of the structure of the bee, with technical terms omitted so far as possible. Practically all of the illustrations are new, and the various parts are interpreted according to the best usage in comparative anatomy of insects. A brief discussion of the physiology of the various organs is included.

\section{BUREAU OF CHEMISTRY.}

Bulletin No. 110, "Chemical Analysis and Composition of American Honeys." By C. A. Browne. Including "A Microscopical Study of Honey Pollen." By W. J. Young. 1908. 93 pp., 1fig., 6 plates. A comprehensive study of the chemical composition of American honeys. This publication is technical in nature and will perhaps be little used by practical beekeepers, but it is an important contribution to apicultural literature. By means of this work the detection of honey adulteration is much aided.

HAWAII AGRICULTURAL EXPERIMENTAL STATION, HONOLULU, HAWAII. Bulletin No. 17, “Hawaiian Honeys." By D. L. Van Dine and Alice R. Thompson. 1908. 21 pp., 1 plate.

A study of the source and composition of the honeys of Hawaii. The peculiar conditions found on these islands are dealt with. 
The folowing bulletins issued by the Texas Department of Agriculture that are available will be forwarded on receipt of request addressed to the Commissioner of Agriculture, Austin, Texas:

No. 1, Third Annual Report Division of Orchard and Nursery Inspection. (Exhausted.)

No. 2, Pecans and Other Nuts in Texas.

No. 3, Proceedings Tenth Texas Farmers' Congress. 1907.

No. 4, Corn Culture. (Exhausted.)

No. 5, Proceedings Eleventh Texas Farmers' Congress, 1908. (Exhausted.)

No. 6, Fourth Annual Report Division of Orchard and Nursery Inspection. (Exhausted.)

No. 7, The Story of Texas. (Exhausted.)

No. 8, The Year Book, 1908. (Exhausted.)

No. 9, Pomological Possibilities of Texas. (Exhausted. See No. 18.)

No. 10, Proceedings Twelfth Texas Farmers' Congress, 1909. (Exhausted.)

No. 11, The Dairy Industry in Texas.

No. 12, The Panhandle and Llano Estacado of Texas. (Exhausted.)

No. 13, The Year Book, 1909. (Exhausted.)

No. 14, The Mineral Resources of Texas.

No. 15, The A. B. C. of Truck Growing.

No. 16, Proceedings Thirteenth Texas Farmers' Congress, 1910. (Exhausted.)

No. 17, Central West Texas.

No. 18, Pomological Possibilities of Texas. (Revised Edition.)

No. 19, The Pecan and Hickory in Texas.

No. 20, Some Especially Valuable Grasses in Texas.

No. 21, Report 'First Meeting Texas State Farmers' Institute.

No. 22, Proceedings Fourteenth 'Texas Farmers' Congress, 1911. (Exhausted.)

No. 23, Corn Culture for Texas Farmers.

No. 24, Texas Beekeeping.

NEW SERIES.

No. 1, Orchard and Nursery Inspection Law, with Rules and Regulations.

No. 2, Some Facts About Texas.

No. 3, Citrus Fruits of Texas.

No. 4, List of Nurseries, 1909. (Exhausted.)

No. 5, Poultry Culture in Texas.

No. 6, The White Fly.

No. 7, List of Nurseries, 1910. (Exhausted.)

No. 8, The Eucalyptus in Texas.

No. 9, Control of Insect Pests and Fungus Diseases.

No. 10, Address of Governors and Commissioners of Agriculture of Southern States, adopted at Cotton Conference held at New Orleans, La., October 30-31, 1911. 



Texas beekeeping 
